\title{
POENTIAL FOR GROUND-WATER CONTAMINATION FROM MOVEMENT OF WASTEWATER THROUGH THE UNSATURATED ZONE, UPPER MOJAVE RIVER BASIN, CALIFORNIA
}

By Amjad M.J. Umari, Peter Martin, Roy A. Schroeder, Lowell F.W. Duell, Jr., and Ronald G. Fay

U.S. GEOLOGICAL SURVEY

Water-Resources Investigations Report 93-4137

Prepared in cooperation with the CALIFORNIA REGIONAL WATER QUALITY

CONTROL BOARD-LAHONTAN REGION and the MOJAVE WATER AGENCY

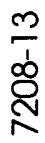




\section{U.S. DEPARTMENT OF THE INTERIOR BRUCE BABBIT, Secretary}

\section{U.S. GEOLOGICAL SURVEY GORDON P. EATON, Director}

Any use of trade, product, or firm names in this publication is for descriptive purposes only and does not imply endorsement by the U.S. Government.

For sale by the U.S. Geological Survey

Earth Science Information Center

Open-File Reports Section

Box 25286, MS 517

Denver Federal Center

Denver, CO 80225

For additional information write to:

District Chief

U.S. Geological Survey

Federal Building, Room W-2233

2800 Cottage Way

Sacramento, CA 95825 


\title{
CONTENTS
}

\author{
Abstract 1 \\ Introduction $\mathbf{2}$ \\ Purpose and scope 2 \\ Acknowledgments $\mathbf{2}$ \\ Description of study area $\mathbf{2}$ \\ General features 2 \\ Geohydrology 5 \\ Geologic units 5 \\ Recharge and discharge 6 \\ Ground-water levels and movement 8 \\ Ground-water quality 9 \\ Sampling and analysis $\mathbf{1 1}$ \\ Site selection 11 \\ Test drilling and instrumentation of study sites $\mathbf{1 1}$ \\ Analysis of soil cores and pore water $\mathbf{1 5}$ \\ Physical analyses 15 \\ Chemical analyses $\mathbf{1 7}$ \\ Microbiological analyses $\mathbf{2 5}$ \\ In situ monitoring in the unsaturated zone $\mathbf{2 6}$ \\ Soil-moisture content $\mathbf{2 6}$ \\ Pore-water quality $\mathbf{2 7}$ \\ Analysis of tapwater and wastewater $\mathbf{4 0}$ \\ Analysis of shallow-ground-water quality $\mathbf{4 0}$ \\ Movement of wastewater through the unsaturated zone $\mathbf{4 8}$ \\ Moisture-content profiles 48 \\ Neutron moisture logs 49 \\ Suction lysimeters $\mathbf{5 1}$ \\ Concentration of selected wastewater constituents in the unsaturated zone $\mathbf{5 4}$ \\ Nitrogen $\mathbf{5 4}$ \\ Nitrogen cycle $\mathbf{5 5}$ \\ Septic-tank wastewater $\mathbf{5 5}$ \\ Nitrogen concentrations and transformations $\quad 59$ \\ Denitrification 67 \\ Total bacteria and fecal coliforms $\mathbf{7 1}$ \\ Other contaminants in wastewater $\mathbf{7 2}$ \\ Potential for ground-water contamination $\mathbf{7 3}$ \\ Summary and conclusions 79 \\ References cited $\mathbf{8 1}$
}

FIGURES

1. Map showing location of study area $\mathbf{3}$

2. Photograph showing Mojave River channel, looking north toward study area $\mathbf{3}$

3. Major land uses and sewered parts of study area $\mathbf{4}$

4. Photograph showing a newly constructed septic tank and seepage pit 5

5. Map showing geology of study area 7

6. Geologic section through study area $\mathbf{8}$

7. Graphs showing water-level altitude of selected wells 9 
8,9. Maps showing:

8. Chemical character of water from selected wells $\mathbf{1 0}$

9. Location of monitoring sites $\mathbf{1 2}$

10,11. Diagrams showing:

10. Typical suction lysimeters, installation, and sampling method $\mathbf{1 7}$

11. Construction of a typical multiple-well monitoring site 43

12-14. Graphs showing:

12. Temporal changes in soil-moisture content and vertical variation in grain size at selected residential sites $\mathbf{5 1}$

13. Vertical variation in selected physical properties and in concentrations of selected chemical and biological constituents at residential sites $\mathbf{6 0}$

14. Influence of selected parameters on model-computed nitrate concentrations in ground water 77

\section{TABLES}

1. Dissolved-solids and nitrate concentrations in samples from selected wells in the study area $\mathbf{1 1}$

2. Location and characteristics of residential wastewater-disposal study sites $\mathbf{1 3}$

3. Location and characteristics of ground-water monitoring sites 14

4. Suction-lysimeter depth and lateral distance from seepage pit $\mathbf{1 6}$

5. Summary of monitoring devices installed and analyses completed at each study site 18

6. Grain-size distribution for core samples at study sites 19

7. Moisture content and pore-water chemical concentration determined from cores at residential study sites 22

8. Fecal coliform and total bacteria (from standard plate count) for core samples at study sites $\mathbf{2 6}$

9. Nitrifying and nitrate-reducing bacteria for core samples from Cheyenne-I and Cajon sites 27

10. Chemical analyses of samples from suction lysimeters $\mathbf{2 8}$

11. Chemical analyses of tapwater at residential study sites $\mathbf{4 1}$

12. Chemical analyses of wastewater at residential study sites $\mathbf{4 2}$

13. Fecal coliform and total bacteria (from standard plate count) in wastewater from septic tanks and seepage pits 43

14. Chemical analyses of ground water from selected residential study sites and multiple-well monitoring sites 43

15. Comparison of wastewater vertical-movement rates determined from neutron moisture logs and from suction lysimeters $\mathbf{5 0}$

16. Calculated increase (or decrease) in concentration of chemical constituents in water during household use 56

17. Median concentrations of selected constituents in tapwater, septic-tank, seepage-pit, and suctionlysimeter samples $\mathbf{5 7}$

18. Nitrogen-isotope data from selected suction lysimeters and monitoring wells, 1989-90 69

19. Specific conductance, concentrations of selected chemical constituents, and nitrogen-isotope ratios in samples from lysimeters at Cajon residential site, 1991-93 71

20. Organic priority pollutants detected in wastewater samples from septic tanks and seepage pits 73

21. Extractable organic compounds, other than priority pollutants, tentatively identified in wastewater samples 74

22. Parameters and values used in the model $\mathbf{7 6}$ 


\section{CONVERSION FACTORS, VERTICAL DATUM, ABBREVIATIONS, AND WELL-NUMBERING SYSTEM}

\section{Conversion Factors}

\begin{tabular}{|c|c|c|}
\hline Multiply & By & To obtain \\
\hline acre & 0.4047 & hectare \\
\hline acre & 4,047 & square meter \\
\hline acre-foot (acre-ft) & 1,233 & cubic meter \\
\hline acre-foot (acre-ft) & 0.001233 & cubic hectometer \\
\hline acre-foot per year (acre- $\mathrm{ft} / \mathrm{yr}$ ) & 0.001233 & cubic hectometer per year \\
\hline cubic foot per day $\left(\mathrm{ft}^{3} / \mathrm{d}\right)$ & 0.02832 & cubic meter per day \\
\hline foot $(\mathrm{ft})$ & 0.3048 & meter \\
\hline foot per day $(\mathrm{ft} / \mathrm{d})$ & 0.3048 & meter per day \\
\hline foot squared per day $\left(\mathrm{ft}^{2} / \mathrm{d}\right)$ & 0.09290 & meter squared per day \\
\hline gallon per day $(\mathrm{gal} / \mathrm{d})$ & 0.003785 & cubic meter per day \\
\hline inch (in.) & 25.4 & millimeter \\
\hline mile (mi) & 1.609 & kilometer \\
\hline square mile $\left(\mathrm{mi}^{2}\right)$ & 259.0 & hectare \\
\hline square mile $\left(\mathrm{mi}^{2}\right)$ & 2.590 & square kilometer \\
\hline
\end{tabular}

Temperature is given in degrees Celsius $\left({ }^{\circ} \mathrm{C}\right)$, which can be converted to degrees Fahrenheit $\left({ }^{\circ} \mathrm{F}\right)$ by the following equation:

$$
{ }^{\circ} \mathrm{F}=1.8\left({ }^{\circ} \mathrm{C}\right)+32 .
$$

\section{Vertical Datum}

Sea Level: In this report, "sea level" refers to the National Geodetic Vertical Datum of 1929- a geodetic datum derived from a general adjustment of the first-order level nets of the United States and Canada, formerly called Sea Level Datum of 1929.

\section{Abbreviations}

CFU/g: Colony-forming units per gram

CFU/100 mL: Colony-forming units per 100 milliliters

g: gram

$\mathrm{mL}:$ milliliter

$\mu \mathrm{g} / \mathrm{kg}: \quad$ microgram per kilogram

$\mathrm{mg} / \mathrm{L}:$ milligram per liter

$\mu \mathrm{g} / \mathrm{L}: \quad$ microgram per liter

$\mu \mathrm{S} / \mathrm{cm}$ : microsiemen per centimeter at 25 degrees Celsius

$\mu \mathrm{m}:$ micrometer

$\mathrm{m}$ : meter

$\mathrm{m} / \mathrm{h}:$ meter per hour 
Wells and springs are identified and numbered according to their location in the rectangular system for the subdivision of public lands. Identification consists of the township number, north or south; the range number, east or west; and the section number. Each section is divided into sixteen 40-acre tracts lettered consecutively (except I and $\mathrm{O}$ ), beginning with " $\mathrm{A}$ " in the northeast corner of the section and progressing in a sinusoidal manner to " $\mathrm{R}$ " in the southeast corner. Within the 40-acre tract, wells are sequentially numbered in the order they are inventoried. The letter "S" inserted before the sequence number indicates a spring. The final letter refers to the base line and meridian. In California, there are three base lines and meridians; Humboldt (H), Mount Diablo (M), and San Bernardino (S). All wells and springs in the study area are referenced to the San Bernardino base line and meridian (S). Numbers consist of 15 characters and follow the format $004 \mathrm{~N} 003 \mathrm{~W} 15 \mathrm{C} 01 \mathrm{~S}$. In this report, well numbers are abbreviated and written $4 \mathrm{~N} / 3 \mathrm{~W}-15 \mathrm{C} 1$. Wells in the same township and range are referred to by only their section designation, $15 \mathrm{C} 1$. The numbering system for lysimeters follows that for wells, with an addition: The letters "LYS" are added at the end (for example, 5N/3W-16E1LYS). The following diagram shows how the number for well $4 \mathrm{~N} / 3 \mathrm{~W}-15 \mathrm{C} 1$ is derived.

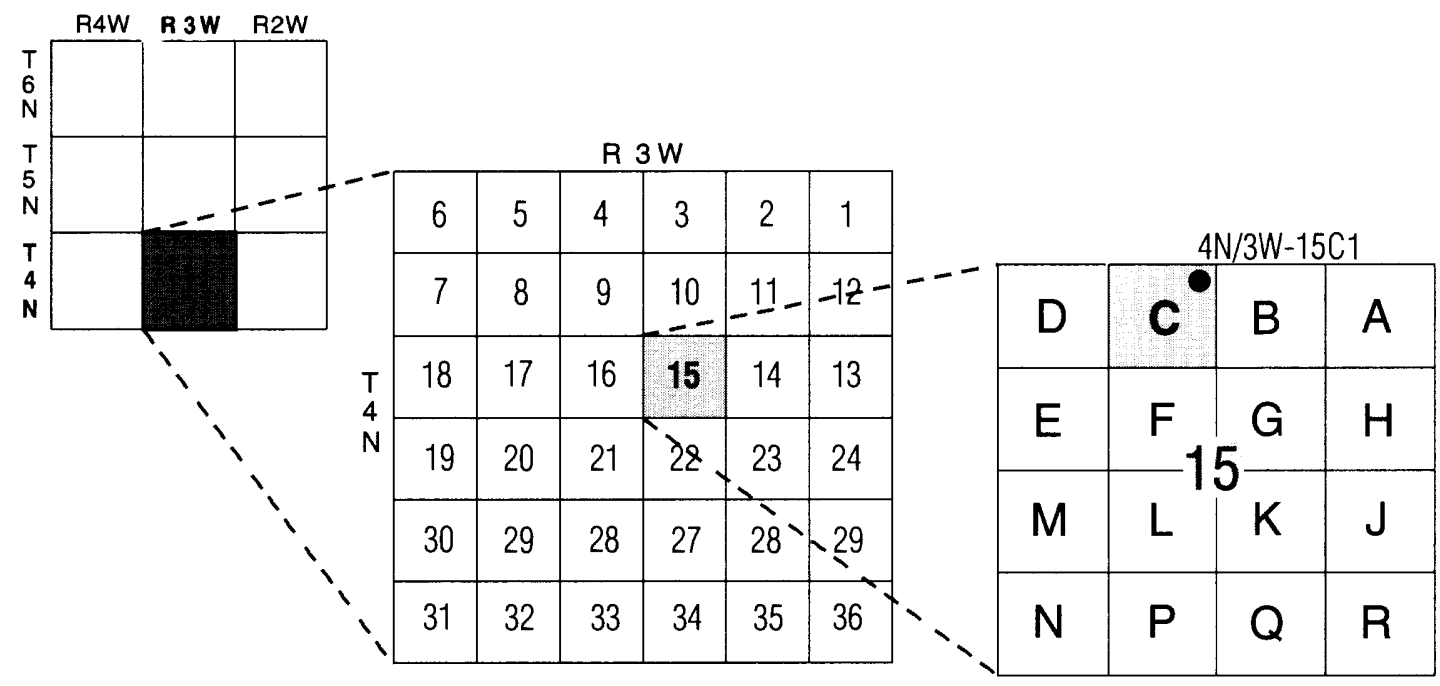




\title{
POTENTIAL FOR GROUND-WATER CONTAMINATION FROM MOVEMENT OF WASTEWATER THROUGH THE UNSATURATED
} ZONE, UPPER MOJAVE RIVER BASIN, CALIFORNIA

\author{
By Amjad M.J. Umari, Peter Martin, Roy A. Schroeder, \\ Lowell F.W. Duell, Jr., and Ronald G. Fay
}

\begin{abstract}
Septic-tank wastewater disposed in 30 -foot-deep seepage pits (dry wells) at 46,000 residences is estimated to equal 18 percent of the natural recharge to the sole-source aquifer in the rapidly developing upper Mojave River Basin (Victor Valley) in the high desert northeast of Los Angeles. Vertical rates of movement of the wastewater wetting front through the unsaturated zone at three newly occupied residences ranged from 0.07 to 1.0 foot per day. These rates translate to traveltimes of several months to several years for the wastewater wetting front to reach the water table and imply that wastewater from many disposal systems already has reached the water table, which averages about 150 feet below land surface in the Victor Valley.
\end{abstract}

As wastewater percolates from seepage pits into the adjacent unsaturated zone, the nitrogen present in reduced form is rapidly converted to nitrate. Analyses on soil-core extracts and soil moisture from suction lysimeters installed beneath the seepage pits at eight residences showed that nitrate concentrations and nitrate/ chloride ratios generally become lower with increasing depth. The intervals of greatest decline seemed to coincide with finer soil texture or were near the water table. Nitrate-reducing bacteria were tested for and found to be present in soil cores from two residences. Sparse nitrogen-15 data from suction lysimeters at one of these residences, where the nitrate concentration decreased by about one-half at a depth of 200 feet, indicate that the nitrate decline was accompanied by nitrogen- 15 enrichment in the residual nitrate with an isotope-separation factor of about -10 permil.

Despite the potential input of abundant nitrogen with the domestic wastewater recharge, nitrate concentrations in the area's ground water are generally low. The absence of high nitrate concentrations in the ground water is consistent with the existence of denitrification, a microbial nitrogen-removal mechanism, as wastewater moves through the thick unsaturated zone and mixes with the ground water. The observed low nitrate concentrations also could be explained by a dilution by vertical mixing in the saturated zone and retention of the wastewater in the unsaturated zone. Results of a single-cell mixing model that allows nitrate from wastewater to be mixed instantaneously with the underlying ground water suggest that measurable increases in nitrate concentration should be expected within 5 to 10 years after wastewater reaches the water table if the mixing depth is less than 100 feet.

Although high fecal-coliform densities were measured in wastewater from septic tanks and seepage pits, removal of these enteric bacteria in the unsaturated zone is very effective, as was indicated by their absence in soil only a few feet from the seepage pits. In testing for organic priority pollutants in wastewater, 17 of 85 compounds were detected. Most compounds detected were present in low concentrations, except at one residence where the concentration of three compounds exceeded 100 micrograms per liter. These high concentrations may be a consequence of disposal practices unique to this residence. Extractable organic priority pollutants 
were not found in any soil cores taken adjacent to seepage pits and, therefore, are not of concern.

\section{INTRODUCTION}

About one-quarter of all inhabitants of the United States dispose of sewage by means of onsite septic systems (Brown and others, 1979) that have the potential to contaminate the receiving waters (Boyle and Otis, 1979). The main cause of failure of these systems has been variously reported to be poor operation and maintenance (Viraraghavan, 1986), unsuitable soils (Duda and Cromartie, 1982), and excessive septic-tank density (Yates, 1985). These conditions exist locally at some residences and regionally in some parts of the upper Mojave River Basin.

Disposal of domestic wastewater from 46,000 residences in the upper Mojave River Basin (Frank Merrill, A1-Desert Septic Systems, Inc., written commun., 1991) is predominantly by discharge of septic-tank effluent to seepage pits (dry wells) from which the wastewater percolates into the unsaturated zone. Rapid population growth in this high-desert area northeast of Los Angeles has led to concern, particularly because alternative public-water supplies are not currently available, that these wastewater-disposal practices could contaminate or pose an increasing threat of contamination to the sole-source aquifer that underlies the area.

To respond to this concern, the U.S. Geological Survey, in cooperation with the California Regional Water Quality Control Board-Lahontan Region and the Mojave Water Agency, began a study in 1988 that had the following objectives:

1. To determine the rate of movement of wastewater through the unsaturated zone and whether wastewater reaches the water table.

2. To determine whether constituents in the wastewater, primarily nitrogen and fecalcoliform bacteria, reach the water table.

3. To evaluate the current and potential effects of wastewater contaminants, particularly nitrate, on ground-water quality in the upper Mojave River Basin.

\section{PURPOSE AND SCOPE}

This report presents results of a study on the movement of septic-tank wastewater and associated contaminants through the unsaturated zone at eight sites chosen to represent a range in (1) geohydrologic conditions, (2) years of seepage-pit operation, and (3) sewage-effluent loading as represented by six singlefamily and two multiple-family residences. The vertical rates of wastewater movement were estimated from neutron-probe data. Water-quality data in the unsaturated zone were obtained from soil cores and from suction lysimeters. Ground-water-quality data were obtained from suction lysimeters (where they were installed below the water table) and from shallow monitoring wells installed in a part of the study area containing numerous residences that dispose of wastewater in seepage pits. Available ground-water-quality data from 20 wells in the study area also are presented in this report.

The last samples collected as part of the original agreement under which this study was funded were taken in January 1990. Data from additional sampling of lysimeters at three sites (Cajon, Vasquez, and Cheyenne-I) were obtained after September 1991 with the financial support of the U.S. Geological Survey's Regional Aquifer-System Analysis study in southern California desert and coastal basins, and selected results are included in this report. Additional data and discussion of results from the ongoing sampling at the Cajon site are published in Schroeder and others (1993).

\section{ACKNOWLEDGMENTS}

Holes drilled at the eight wastewater-disposal sites were on private residences, and thus the authors are indebted to the homeowners. The authors also thank the members of a Technical Advisory Committee consisting of local citizens, business owners, and government officials for helpful guidance, and especially the Apple Valley Ranchos Water Company and Hi-Desert Septic Systems for providing space to store drilling equipment and supplies and providing buildings for use as field laboratories.

\section{DESCRIPTION OF STUDY AREA}

\section{GENERAL FEATURES}

The upper Mojave River Basin is in the Mojave Desert region of southern California, about 80 miles northeast of Los Angeles (fig. 1). The study area includes the part of the upper Mojave River Basin adjacent to the Mojave River that locally is referred to as "Victor Valley." The approximately $180-\mathrm{mi}^{2}$ 


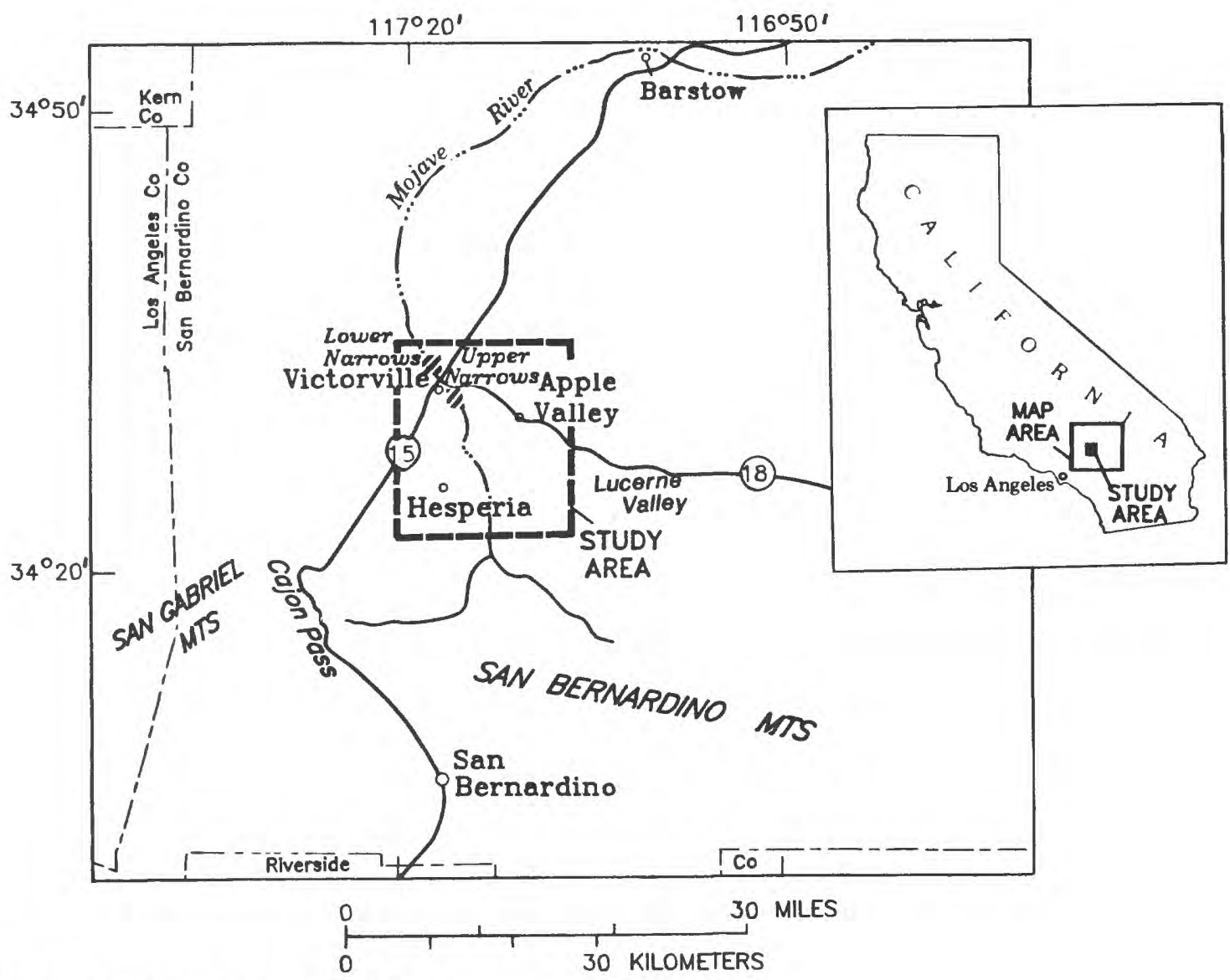

Figure 1. Location of study area.

study area includes the communities of Victorville, Apple Valley, and Hesperia.

The Mojave River, which bisects the study area, originates in the foothills of the San Bernardino Mountains and flows northward toward Victorville. In the upper Mojave River Basin, perennial streamflow occurs only in the mountains and near Victorville where a basin constriction created by shallow bedrock, locally referred to as the "Narrows," causes ground water to discharge to the river. An aerial photograph of the dry river channel near the study area is shown in figure 2.

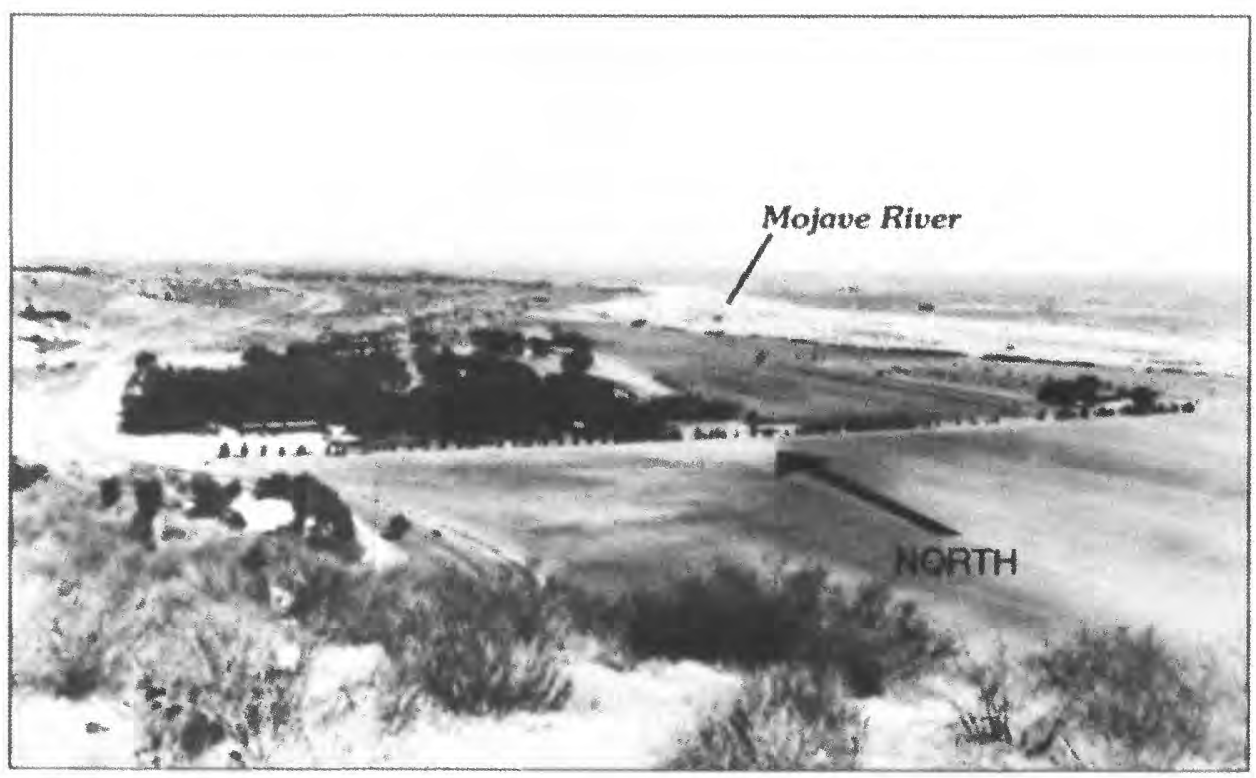

Figure 2. Mojave River channel, looking north toward study area.

The climate of the upper Mojave River Basin is typical of the arid high-desert region of southern California. It is characterized by low precipitation, low humidity, high summer temperatures, and strong winds at certain times of 


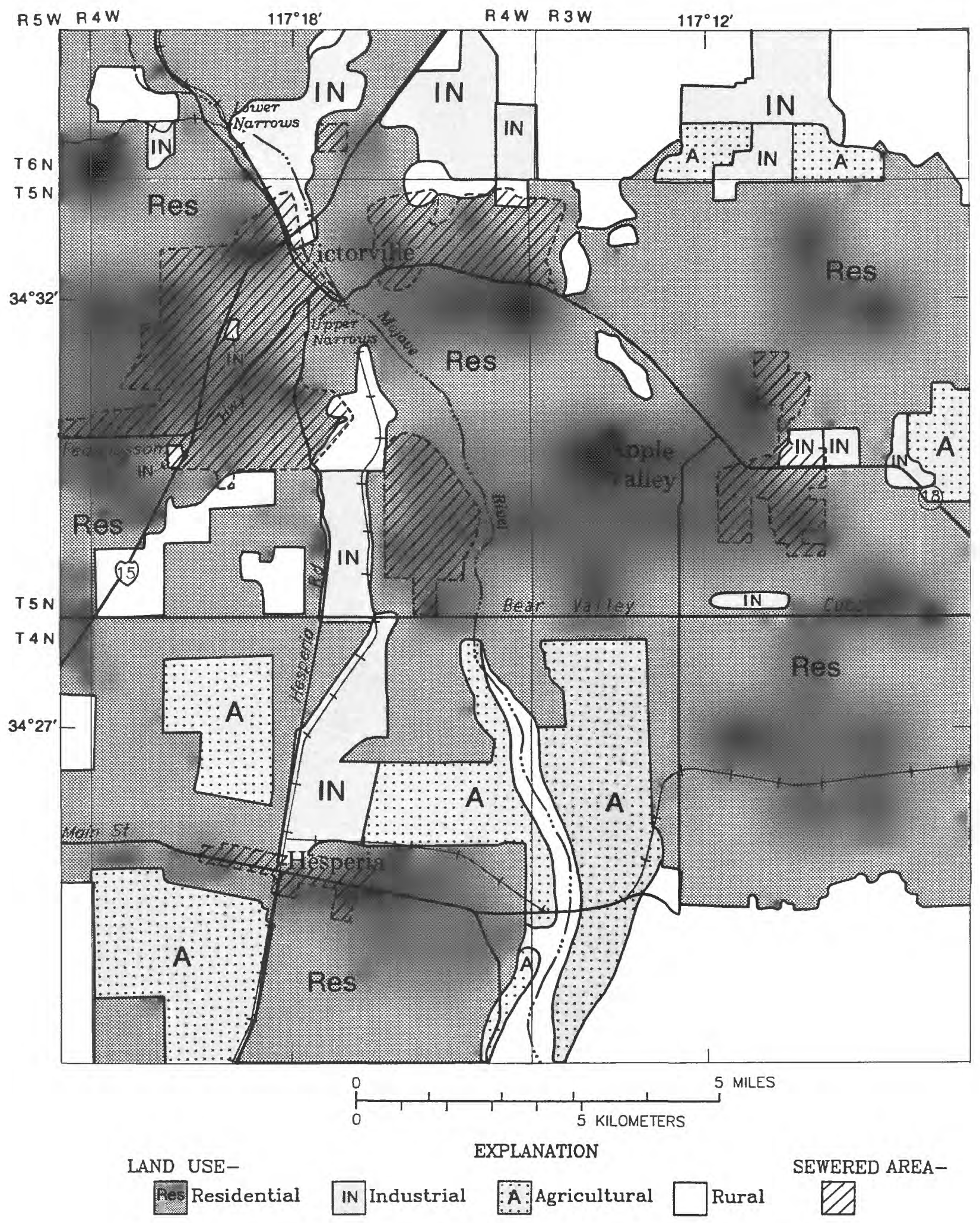

Figure 3. Major land uses and sewered parts of study area.

the year (Hardt, 1971, p. 5). Average annual precipitation at Victorville is 5.1 in. (National Oceanic and Atmospheric Administration, 1989).
Land use in the study area is predominantly residential (fig. 3). Most of this residential development occurred in the 1980 's, reflecting the inland 


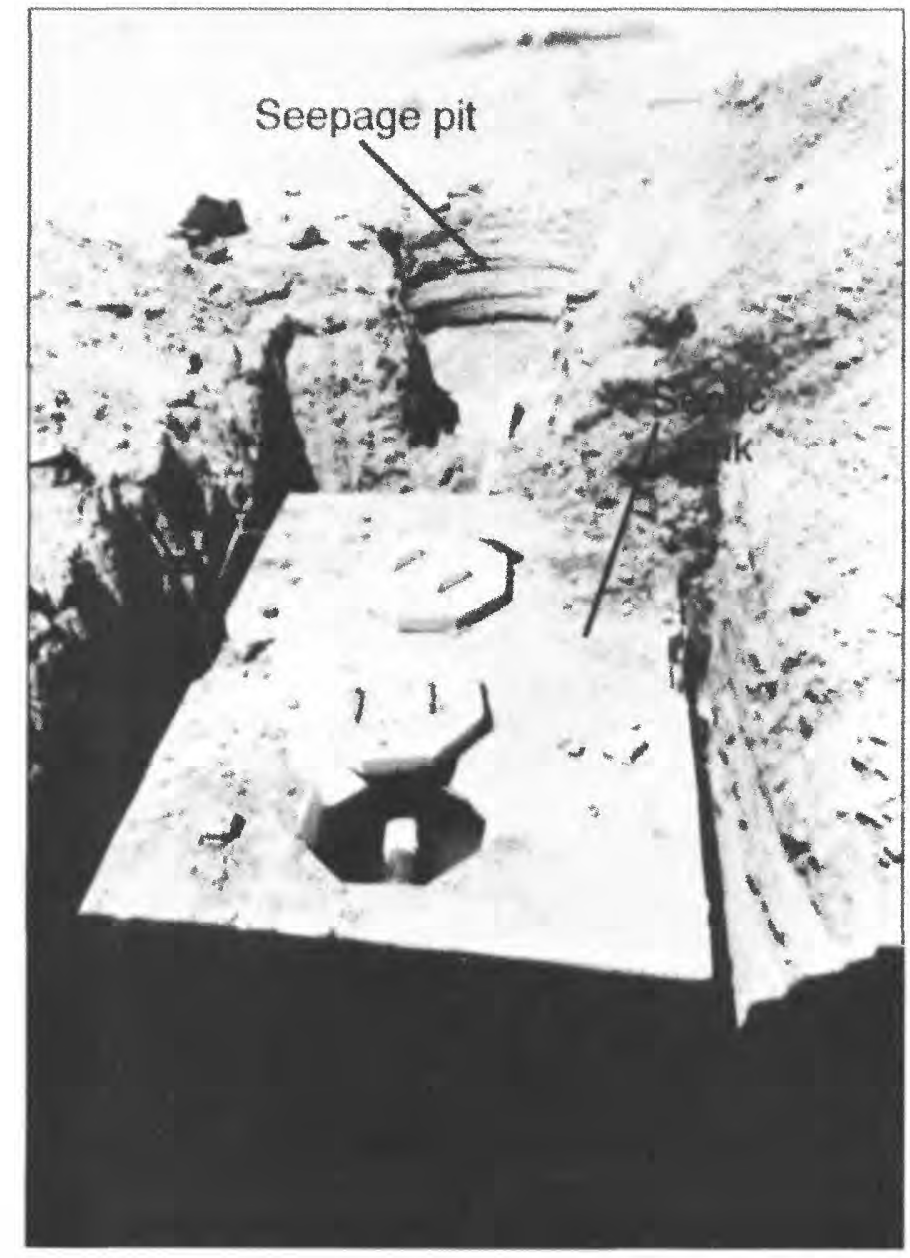

Figure 4. Newly constructed septic tank and seepage pit.

growth of the Los Angeles megalopolis. In 1990, the population of the upper Mojave River Basin was about 200,000 (California Regional Water Quality Control Board, written commun., 1991). Prior to the 1980 's, most of the study area was undeveloped. Earlier, development of agricultural and residential areas occurred primarily along the Mojave River (California Department of Water Resources, 1967, p. 9).

Ground water historically has been the sole source of water in the upper Mojave River Basin. In the study area, water for municipal and industrial use is supplied by large-capacity supply wells. Water from these wells is delivered to individual residences and industrial sites by a series of pipelines. Only a few domestic wells exist in the study area.

Most of the study area is unsewered (fig. 3). The use of shallow leach fields to dissipate wastewater from septic tanks is not possible because of the pres- ence of low-permeability caliche layers in most of the study area. Instead, the wastewater from septic tanks is discharged into deep seepage pits (dry wells). The seepage pits are typically about $5 \mathrm{ft}$ in diameter, about $30 \mathrm{ft}$ deep, and are lined with bricks or blocks with unmortared joints that allow rapid percolation of the wastewater into the unsaturated zone. A photograph of a newly constructed septic tank and seepage pit is shown in figure 4.

\section{GEOHYDROLOGY}

\section{GEOLOGIC UNITS}

The geologic units in the study area are grouped into two broad categories according to their waterbearing characteristics: non-water-bearing and waterbearing formations (California Department of Water Resources, 1967, p. 18).

The non-water-bearing formations include metamorphic and igneous rocks of pre-Tertiary age (basement complex) and sedimentary continental rocks of Tertiary age. These formations underlie the basin and form the surrounding mountains and hills (figs. 5 and 6). The Tertiary sedimentary rocks include some water-bearing units; however, yields from wells generally are low, and most of the water is of poor quality (California Department of Water Resources, 1967, p. 26).

The water-bearing formations of the upper Mojave River Basin resulted primarily from erosion of the surrounding mountains. These formations consist of gravel- to clay-size material and generally become more consolidated and less permeable with increasing depth. The water-bearing formations include younger alluvium of Holocene age, and old lake and lakeshore deposits, older alluvium, older fan deposits, landslide breccia, Shoemaker Gravel, and the Harold Formation of Pleistocene age (California Department of Water Resources, 1967).

The younger alluvium, as used in this report, includes the river deposits, dune sand, younger alluvium, and younger fan deposits mapped by the California Department of Water Resources (1967). These deposits generally are the most permeable of all the geologic units and, where saturated, yield large quantities of water to wells. In the study area, the younger alluvium is saturated only beneath the Mojave River channel (fig. 6). Throughout the remainder of the study area, the younger alluvium is only a veneer overlying older materials. 
Old lake and lakeshore deposits are exposed on both sides of the Mojave River near Victorville (fig. 5). The old lake deposits consist predominantly of silt and clay and are generally less than $75 \mathrm{ft}$ thick. Where saturated, the old lake deposits yield little water to wells, and where unsaturated, percolation rates are very low. The lakeshore deposits are remnants of sand and gravel bars of Late Pleistocene lakes (California Department of Water Resources, 1967, p. 23) and are generally permeable.

The older alluvium underlies most of the study area and ranges in thickness from a few feet to more than $250 \mathrm{ft}$ beneath the Mojave River channel (fig. 6). The deposits consist of unconsolidated to consolidated, poorly sorted gravel, sand, silt, and clay. In the Hesperia area these deposits yield water freely to wells; however, in parts of Apple Valley the water-yielding characteristics of these deposits are poor. Caliche deposits near land surface in much of the area prevent the percolation of rainfall, and deep seepage pits extending below the caliche deposits must be constructed to discharge wastewater from septic tanks.

The older fan deposits are exposed (fig. 5) along the flanks of the highland areas. These partly consolidated deposits consist of poorly sorted gravel, sand, silt, and clay. Reported well yields from the older fan deposits are variable but generally are low (California Department of Water Resources, 1967, p. 24). As in the areas of older alluvium, the older fan deposits in places are cemented with caliche near land surface, requiring the installation of seepage pits to discharge wastewater from septic tanks.
The other water-bearing formations are well below the water table in the study area and have no effect on the movement of wastewater.

\section{RECHARGE AND DISCHARGE}

The principal source of natural recharge in the upper Mojave River Basin is precipitation in the San Bernardino Mountains south of the study area. Most of this recharge occurs as percolation of floodflows in the Mojave River and is estimated to average 40,000 acre-ft/yr for the period 1931-92 (G.C. Lines, U.S. Geological Survey, written commun., 1993). Smaller sources of recharge to the upper Mojave River Basin are mountain-front runoff from the San Gabriel Mountains (9,300 acre-ft/yr) and subsurface inflow from Lucerne Valley (250 acre-ft/yr) (Hardt, 1971). Direct infiltration of precipitation on the basin floor is considered negligible because, in most places, potential evapotranspiration greatly exceeds annual precipitation. In addition, the presence of shallow caliche deposits throughout much of the basin impedes the percolation of precipitation.

Discharge occurs naturally from the basin as evapotranspiration, streamflow (base flow), and subsurface outflow at the "Narrows" near Victorville, where a basin constriction caused by shallow bedrock forces ground water to the surface. Natural groundwater discharge, however, is significantly less than municipal and agricultural pumpage. Total pumpage from the upper Mojave River Basin in 1990 is estimated to have been 124,000 acre-ft (Jack Clark, Apple Ranchos Water District, written commun.,

EXPLANATION FOR FIGURE 5

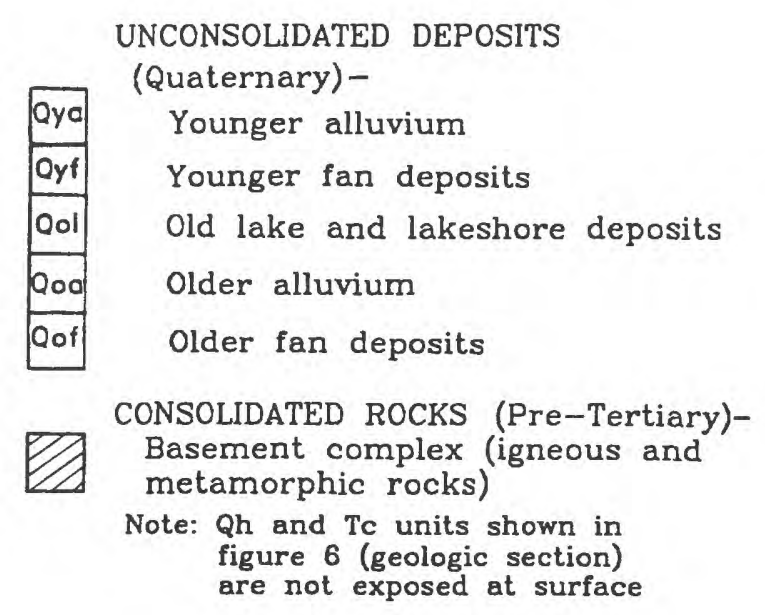

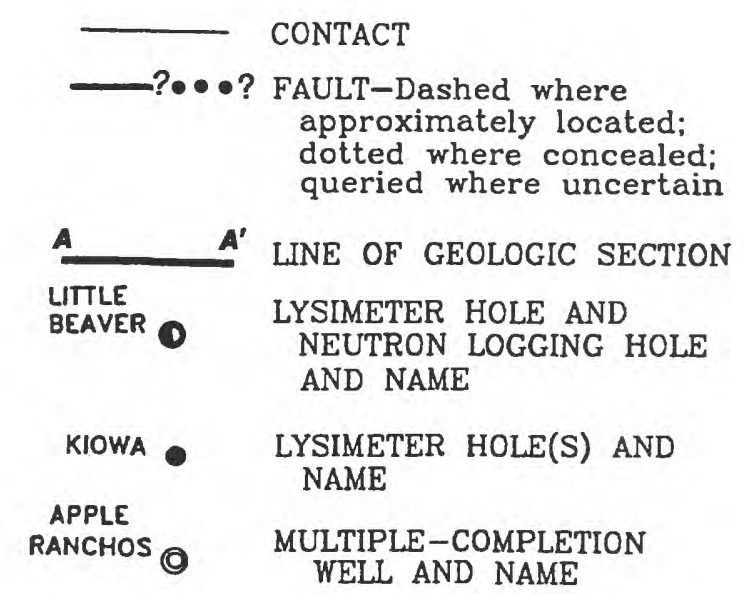


1991). Historically, most of the pumpage was from the younger alluvium along the Mojave River channel. As development in the area has expanded, pumpage from the older deposits has increased. Part of the pumped water returns to the basin as irrigation return flows and septic-tank wastewater. Evapotran- spiration is estimated to be 9,000 acre- $\mathrm{ft} / \mathrm{yr}$ (Hardt, 1971 , p. 43). Base flow was about 8,000 acre-ft/yr in 1990 (G.C. Lines, U.S. Geological Survey, written commun., 1992), and subsurface outflow at the "Narrows" is estimated to be 350 acre-ft/yr (Slichter, 1905, p. 63).

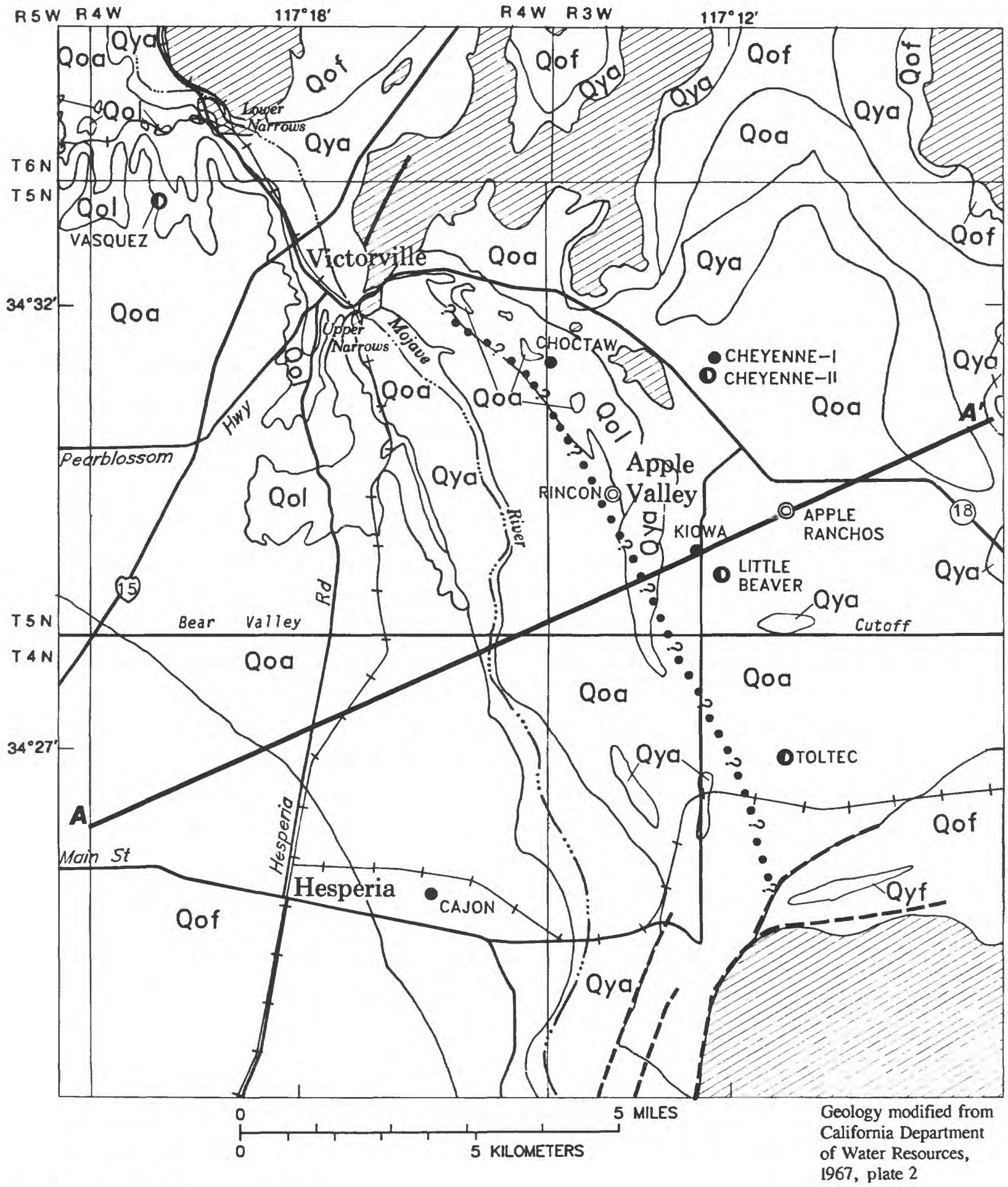

Figure 5. Geology of study area. 


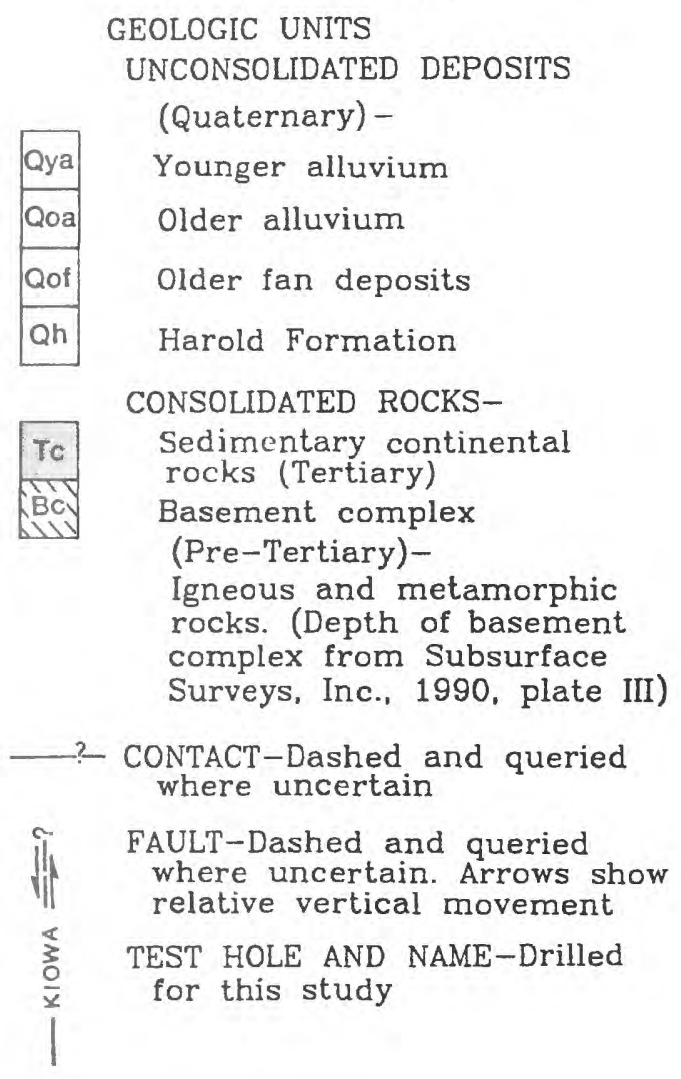

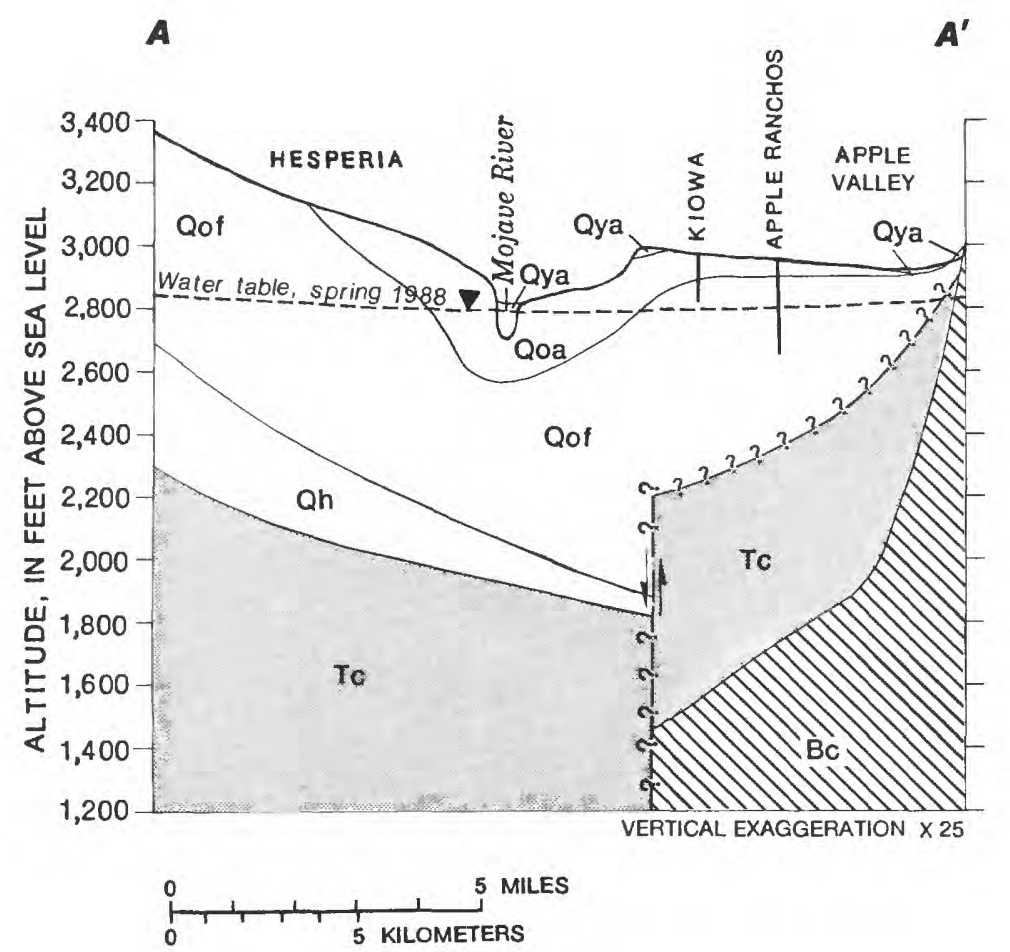

Figure 6. Geologic section through study area.

\begin{tabular}{lrlr}
\hline \multicolumn{2}{c}{ Recharge } & \multicolumn{2}{c}{ Discharge } \\
\hline $\begin{array}{l}\text { Mojave River } \\
\begin{array}{l}\text { Mountain front } \\
\text { runoff }\end{array}\end{array}$ & 40,000 & $\begin{array}{l}\text { Pumpage } \\
\text { Evapotrans- } \\
\text { piration }\end{array}$ & 124,000 \\
Subsurface inflow & 9,300 & $\begin{array}{l}9,000 \\
\text { Base flow } \\
\text { Subsurface out- } \\
\text { flow }\end{array}$ & 8,000 \\
\cline { 2 - 3 } & 49,550 & & 141,350 \\
Loss $=91,800$ acre-ft/yr if pumping return flows are \\
ignored.
\end{tabular}

As stated above, septic-tank wastewater discharged to seepage pits installed to depths below the shallow caliche deposits decreases the net pumpage (total pumpage-returns) from the basin. In 1990 , there were approximately 46,000 septic-tank systems in use in the upper Mojave River Basin area (Frank Merrill, Hi-Desert Septic Systems, Inc., written commun., 1991). Assuming an average septic-tank discharge of $70(\mathrm{gal} / \mathrm{d}) /$ person (Bookman-Edmonston
Engineering, 1991), and 2.5 people per household, annual septic-tank wastewater discharge is estimated to have been 9,000 acre-ft/yr in 1990 , equal to about 18 percent of the estimated natural recharge to the basin.

\section{GROUND-WATER LEVELS AND MOVEMENT}

In general, ground water adjacent to the Mojave River flows from south to north. East and west of the Mojave River, ground water flows toward the river. Pumping in Apple Valley has resulted in local waterlevel depressions (John S. Murk Engineering, Inc., and LeRoy Crandall and Associates, 1985, p. 3-11).

Depth to ground water generally increases from the center of the basin toward the surrounding mountain ranges and their upward-sloping alluvial fans. Depth to water in the study area ranges from less than $50 \mathrm{ft}$ beneath the Mojave River to more than $400 \mathrm{ft}$ below land surface at Hesperia, west of the river (fig. 6). In Apple Valley the depth to water ranges from 100 to $150 \mathrm{ft}$ north of Bear Valley Cutoff 


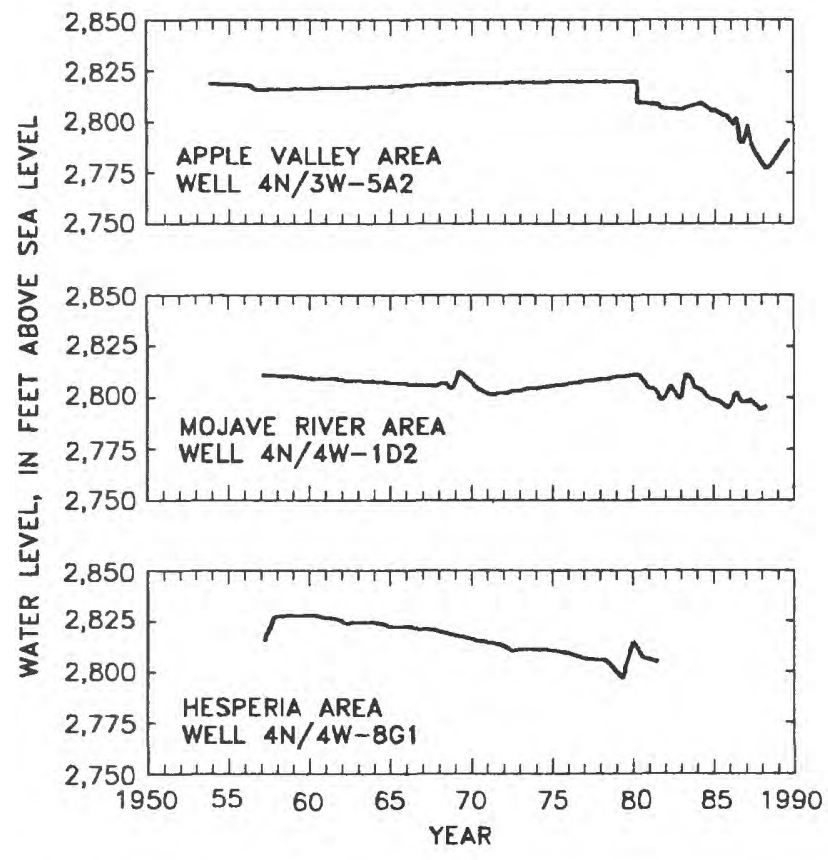

Figure 7. Water-level altitude of selected wells.

and from 150 to more than $400 \mathrm{ft}$ south of Bear Valley Cutoff (fig. 5) (Subsurface Surveys, Inc., 1990, pl. 4).

Ground-water pumpage exceeds natural recharge to the basin, and water levels are declining throughout the study area (fig. 7). The water-level declines have been largest in the Apple Valley area (fig. 7), where water levels have declined by almost $50 \mathrm{ft}$ since the early 1950's. Most of the observed water-level decline in the Apple Valley area has occurred since the rapid increase in residential development during the 1980's.

\section{GROUND-WATER QUALITY}

The chemical character of water from selected wells (on the basis of available data collected during 1978-90) is shown in figure 8. The water-quality diagrams in figure 8 depict the concentrations of major cations and anions, and give an approximate indication of total-ion content. The dissolved-solids concentration of samples from the wells shown in figure 8 is given in table 1 .

Samples from wells adjacent to and west of the Mojave River generally have dissolved-solids concentrations less than $200 \mathrm{mg} / \mathrm{L}$. Dissolved-solids concentration of samples from wells east of the river is dramatically higher, ranging from $113 \mathrm{mg} / \mathrm{L}(4 \mathrm{~N} / 3 \mathrm{~W}$ 7P1), within $0.5 \mathrm{mi}$ of the river, to $1,030 \mathrm{mg} / \mathrm{L}$
(4N/3W-15C1), more than $3 \mathrm{mi}$ from the river (fig. 8, table 1). The water-quality diagrams indicate that composition of the water also differs significantly. Most of the samples from wells east of the river contain much higher concentrations of chloride than do samples from wells adjacent to and west of the river. The distributions of dissolved-solids concentration and water composition are similar to those shown by California Department of Water Resources (1967, pl. 6) for 1967. This earlier study was completed prior to most of the development in the area and suggests that the source of the high dissolved-solids concentrations is geologic, rather than anthropogenic.

A gravity survey of the study area (Subsurface Surveys, Inc., 1990, pl. 3) indicates that the basement complex rises sharply toward land surface east of the Mojave River (fig. 6), underlying areas where dissolved-solids concentrations are observed to be high. The rapid rise in altitude of the basement complex suggests the presence of a fault that has uplifted the basement complex east of the Mojave River (fig. 6). In any case, the depth to the basement complex and the overlying continental deposits of Tertiary age (where they have not been removed by erosion) decreases rapidly east of the river. Therefore, wells east of the river could penetrate the lowpermeability continental deposits at shallower depths than wells west of the river. This observation is supported by Hardt (1971, fig. 8), who showed that transmissivity decreases sharply toward the mountains east of the Mojave River. As stated previously, the continental deposits contain water of poor quality and are presumed to be the source of the high dissolvedsolids concentrations east of the Mojave River.

Available nitrate data obtained from wells during 1978-90 are given in table 1 as nitrite plus nitrate as nitrogen $\left(\mathrm{NO}_{2}+\mathrm{NO}_{3}-\mathrm{N}\right)$. Nitrate-N concentrations generally are less than $2 \mathrm{mg} / \mathrm{L}$ throughout the study area-considerably less than the U.S. Environmental Protection Agency (1976) maximum contaminant level of $10 \mathrm{mg} / \mathrm{L}$ for drinking water. Because nitrite concentrations generally are negligible, the concentrations given in table 1 are virtually the same as nitrate concentrations.

The low nitrate concentrations in the upper Mojave River Basin are of particular interest because ground-water nitrate concentrations commonly are high in areas where wastewater is discharged from septic-tank systems (Bouwer, 1978). The movement of nitrate from the septic tank through the unsaturated zone to the underlying ground water and its effect on 


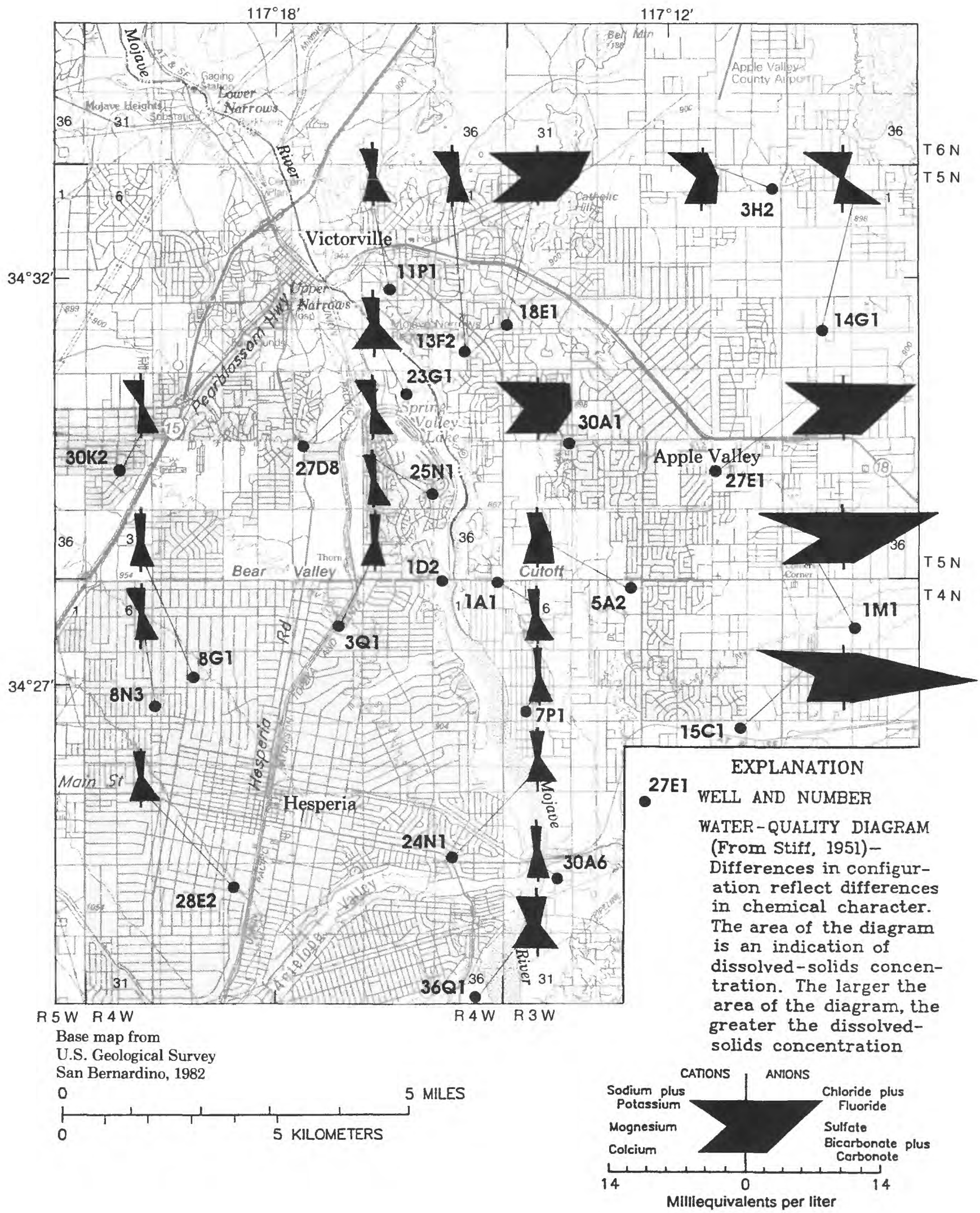

Figure 8. Chemical character of water from selected wells. 
Table 1. Dissolved-solids and nitrate concentrations in samples from selected wells in the study area

[Well No: See "Well-Numbering System" in text. ft, foot; mg/L, milligram per liter; --, no data]

\begin{tabular}{|c|c|c|c|c|}
\hline Well No. & $\begin{array}{l}\text { Date } \\
\text { of } \\
\text { sample }\end{array}$ & $\begin{array}{c}\text { Well } \\
\text { depth } \\
\text { (ft) }\end{array}$ & $\begin{array}{l}\text { Dissolved solids, } \\
\text { calculated sum of } \\
\text { constituents } \\
(\mathrm{mg} / \mathrm{L})\end{array}$ & $\begin{array}{c}\text { Nitrogen, } \\
\mathrm{NO}_{2}+\mathrm{NO}_{3} \\
\text { dissolved } \\
(\mathrm{mg} / \mathrm{L} \text { as } \mathrm{N}) \\
\end{array}$ \\
\hline $4 \mathrm{~N} / 3 \mathrm{~W}-1 \mathrm{M} 1$ & 4-07-80 & -- & 990 & 1.6 \\
\hline$-5 A 2$ & $6-24-87$ & 300 & 213 & .58 \\
\hline$-7 \mathrm{P} 1$ & $5-27-87$ & 415 & 113 & .61 \\
\hline$-15 C 1$ & $6-08-89$ & 390 & 1,030 & .32 \\
\hline$-3 A 6$ & $5-22-90$ & 120 & 118 & .30 \\
\hline $4 \mathrm{~N} / 4 \mathrm{~W}-1 \mathrm{~A} 1$ & $5-27-88$ & 275 & 140 & 2.3 \\
\hline$-3 \mathrm{Q} 1$ & $6-08-89$ & 400 & 125 & .33 \\
\hline$-8 G 1$ & 4-08-89 & 610 & 106 & .96 \\
\hline$-8 N 3$ & $6-06-89$ & 900 & 135 & 2.2 \\
\hline$-24 N 1$ & $4-08-80$ & 452 & 133 & 2.5 \\
\hline$-28 \mathrm{E} 2$ & $4-08-80$ & 593 & 143 & .77 \\
\hline$-36 Q 1$ & $5-27-87$ & -- & 274 & 4.9 \\
\hline $5 \mathrm{~N} / 3 \mathrm{~W}-3 \mathrm{H} 2$ & $6-07-89$ & 223 & 329 & 2.1 \\
\hline$-14 \mathrm{G} 1$ & $7-11-78$ & 226 & 253 & .09 \\
\hline$-18 \mathrm{E} 1^{1}$ & $8-23-89$ & 131 & 703 & .73 \\
\hline$-27 \mathrm{E} 1^{2}$ & $8-22-89$ & 240 & 814 & 1.7 \\
\hline$-30 \mathrm{~A} 1^{3}$ & $8-23-89$ & 285 & 542 & .89 \\
\hline $5 \mathrm{~N} / 4 \mathrm{~W}-11 \mathrm{P} 1$ & $5-22-90$ & -- & 148 & .90 \\
\hline$-13 F 2$ & $5-22-90$ & 260 & 170 & .40 \\
\hline$-23 G 1$ & $5-27-87$ & 63 & 217 & .49 \\
\hline$-25 \mathrm{~N} 1$ & $5-24-90$ & 400 & 122 & .50 \\
\hline$-27 \mathrm{D} 8$ & $6-07-89$ & 520 & 137 & 1.9 \\
\hline$-30 \mathrm{~K} 2$ & $6-07-89$ & 650 & 127 & .31 \\
\hline
\end{tabular}

${ }^{1}$ Choctaw site--suction lysimeter at $131 \mathrm{ft}$.

${ }^{2}$ Apple Ranchos multiple-completion well.

${ }^{3}$ Rincon multiple-completion well.

nitrate concentrations in the ground water will be addressed in subsequent sections of this report.

\section{SAMPLING AND ANALYSIS}

\section{SITE SELECTION}

Test holes for studies in the unsaturated zone were drilled at eight sites (fig. 9) chosen to represent a range in geohydrologic conditions, years of seepage-pit operation, and residential density. All sites are located away or upgradient from areas of either current or historical agricultural land use (fig. 3). Residential density, date of seepage-pit construction, surface geology, and other pertinent characteristics of each of these sites are given in table 2.

At four of the eight sites (Cheyenne-I and -II, Choctaw, and Cajon), sampling devices were installed below the water table to determine possible effects of wastewater on ground-water quality. In addition, two multiple-well monitoring sites (fig. 9) were installed-one upgradient (Apple Ranchos) and one downgradient (Rincon) of a group of mostly older residences that dispose of wastewater in seepage pits - to determine the importance of dilution by vertical mixing in the saturated zone. Location and characteristics of all ground-water-sampling devices and monitoring wells are given in table 3 .

\section{TEST DRILLING AND INSTRUMENTATION OF STUDY SITES}

Test holes for installation of suction lysimeters and neutron-probe access tubes were drilled using a 9.75-inch-diameter hollow-stem auger at seven of the eight sites and using a drilling process referred to as ODEX (overburden drilling by the excenter [Swedish 


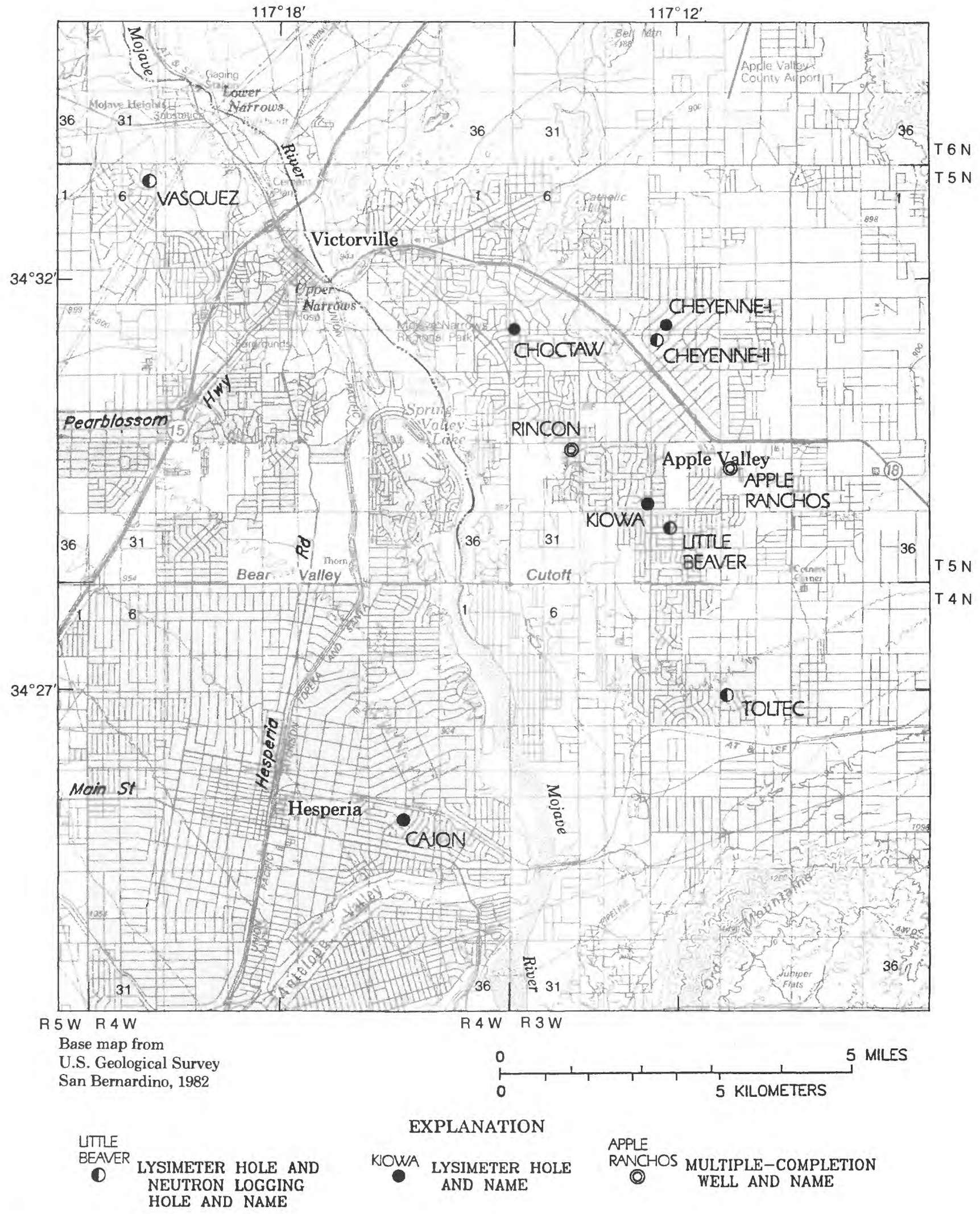

Figure 9. Location of monitoring sites. 


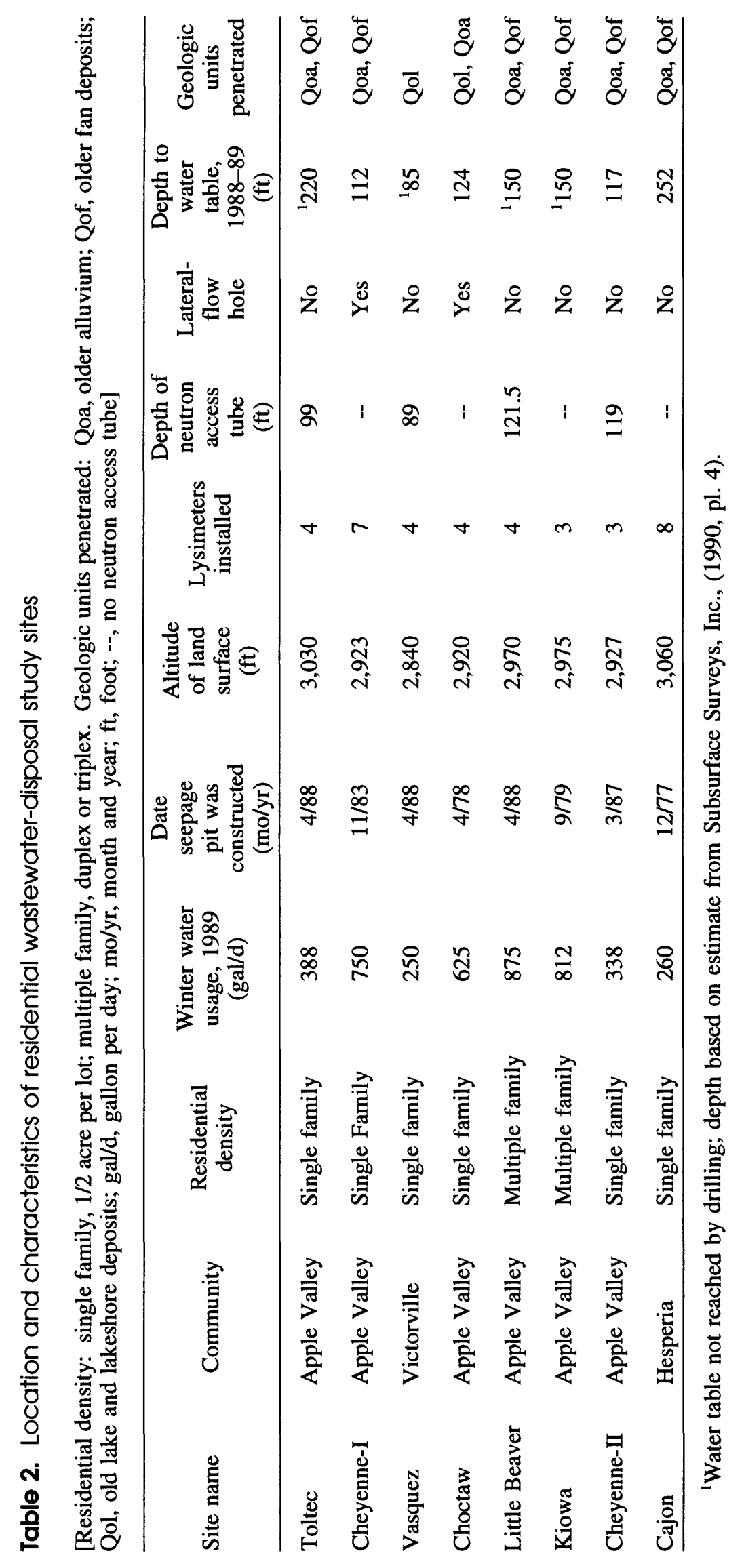


Table 3. Location and characteristics of ground-water monitoring sites

[Well No: See "Well-Numbering System" in text (LYS at end of well number indicates lysimeter). Altitude in feet above sea level. Depths and sampling interval in feet below land surface]

\begin{tabular}{|c|c|c|c|c|c|c|c|c|}
\hline Site name & Well No. & $\begin{array}{l}\text { Altitude } \\
\text { of land } \\
\text { surface }\end{array}$ & $\begin{array}{c}\text { Type of } \\
\text { monitoring } \\
\text { device }\end{array}$ & $\begin{array}{l}\text { Depth of } \\
\text { monitoring } \\
\text { device }\end{array}$ & $\begin{array}{c}\text { Sampling } \\
\text { interval }\end{array}$ & $\begin{array}{l}\text { Depth } \\
\text { to water } \\
\text { table }\end{array}$ & $\begin{array}{c}\begin{array}{c}\text { Date of } \\
\text { measure- } \\
\text { ment }\end{array} \\
\end{array}$ & Remarks \\
\hline Cheyenne-I & $5 N / 3 W-16 E 1 L Y S$ & 2,923 & $\begin{array}{l}\text { Suction } \\
\text { lysimeter } \\
\text { below } \\
\text { water table }\end{array}$ & 113 & $112.5-113$ & 112 & $4-9-88$ & $\begin{array}{l}\text { Water level } \\
\text { measured } \\
\text { when hole } \\
\text { drilled }\end{array}$ \\
\hline Choctaw & $5 N / 3 W-18 E 1 L Y S$ & 2,920 & $\begin{array}{l}\text { Suction } \\
\text { lysimeter } \\
\text { below } \\
\text { water table }\end{array}$ & 131 & $130.5-131$ & 124 & $4-13-88$ & $\begin{array}{l}\text { Water level } \\
\text { measured } \\
\text { when hole } \\
\text { drilled }\end{array}$ \\
\hline Cheyenne-II & $5 \mathrm{~N} / 3 \mathrm{~W}-16 \mathrm{M} 1$ & 2,927 & $\begin{array}{l}\text { Neutron } \\
\text { access tube }\end{array}$ & 123 & $119-123$ & $\begin{array}{l}\text { Min. } 117.3 \\
\text { Max. } 120.70\end{array}$ & $\begin{array}{r}9-12-88 \\
6-9-88\end{array}$ & $\begin{array}{l}\text { Well point } \\
\text { attached to } \\
\text { neutron } \\
\text { access tube }\end{array}$ \\
\hline \multirow[t]{2}{*}{ Cajon } & $4 \mathrm{~N} / 4 \mathrm{~W}-23 \mathrm{~F} 1 \mathrm{LYS}$ & 3,060 & $\begin{array}{l}\text { Lysimeter } \\
\text { below } \\
\text { water table }\end{array}$ & 257 & $256.5-257$ & $\begin{array}{l}\text { Min. } 253.2 \\
\text { Max. } 254.3\end{array}$ & $\begin{array}{l}12-9-89 \\
1-11-90\end{array}$ & \\
\hline & $4 \mathrm{~N} / 4 \mathrm{~W}-23 \mathrm{~F} 9$ & 3,060 & Piezometer & 266 & $254-260.8$ & $\begin{array}{l}\text { Min. } 253.2 \\
\text { Max. } 254.3\end{array}$ & $\begin{array}{l}12-9-89 \\
1-11-90\end{array}$ & $\begin{array}{l}1.5 \text {-inch } \\
\text { pipe }\end{array}$ \\
\hline \multirow[t]{4}{*}{$\begin{array}{l}\text { Apple } \\
\text { Ranchos }\end{array}$} & $5 \mathrm{~N} / 3 \mathrm{~W}-27 \mathrm{E} 3$ & 2,950 & $\begin{array}{l}\text { Multiple- } \\
\text { completion } \\
\text { well }\end{array}$ & 240 & $232-236.5$ & $\begin{array}{l}\text { Min. } 153.69 \\
\text { Max. } 170.09\end{array}$ & $\begin{array}{r}2-6-89 \\
8-22-89\end{array}$ & $\begin{array}{l}\text { Upgradient } \\
\text { multiple-well } \\
\text { monitoring } \\
\text { site }\end{array}$ \\
\hline & $-27 \mathrm{E} 4$ & 2,950 & do. & 199 & $189-194$ & $\begin{array}{l}\text { Min. } 152.74 \\
\text { Max. } 163.48\end{array}$ & $\begin{array}{r}2-6-89 \\
8-22-89\end{array}$ & \\
\hline & $-27 \mathrm{E} 5$ & 2,950 & do. & 173 & $163-168$ & $\begin{array}{l}\text { Min. } 151.62 \\
\text { Max. } 158.99\end{array}$ & $\begin{array}{r}12-15-88 \\
8-22-89\end{array}$ & \\
\hline & $-27 \mathrm{E} 6$ & 2,950 & do. & 152 & $143-148$ & $\begin{array}{l}\text { Min. } 145.73 \\
\text { Max. } 147.04\end{array}$ & $\begin{array}{r}6-2-88 \\
\left({ }^{1}\right)\end{array}$ & \\
\hline \multirow[t]{3}{*}{ Rincon } & $5 \mathrm{~N} / 3 \mathrm{~W}-30 \mathrm{~A} 1$ & 2,960 & $\begin{array}{l}\text { Multiple- } \\
\text { completion } \\
\text { well }\end{array}$ & 285 & $270-280$ & $\begin{array}{l}\text { Min. } 175.74 \\
\text { Max. } 185.99\end{array}$ & $\begin{array}{r}3-7-89 \\
8-13-89\end{array}$ & $\begin{array}{l}\text { Downgradient } \\
\text { multiple-well } \\
\text { monitoring } \\
\text { site }\end{array}$ \\
\hline & $-30 \mathrm{~A} 2$ & 2,960 & do. & 233 & $218-228$ & $\begin{array}{l}\text { Min. } 177.22 \\
\text { Max. } 182.92\end{array}$ & $\begin{array}{r}3-7-89 \\
8-23-89\end{array}$ & \\
\hline & $-30 \mathrm{~A} 3$ & 2,960 & do. & 200 & $185-195$ & $\begin{array}{l}\text { Min. } 177.14 \\
\text { Max. } 181.14\end{array}$ & $\begin{array}{r}3-7-89 \\
4-12-89\end{array}$ & \\
\hline
\end{tabular}

${ }^{1} 147.04$ feet is depth from land surface to bottom of perforation; depth to water level exceeded this on 6-7-88, 7-23-88, 8-9-88, 9-13-88, 10-14-88, and 8-22-89. 
for "eccentric"] method) at the Cajon site because of the greater depth (more than $250 \mathrm{ft}$ ) to the water table. Cores were taken from each of the test holes using an 18-inch stainless steel split-spoon core barrel driven into the undisturbed material ahead of the drill or auger bits.

The ODEX method, which consists of a percussion hammer and an eccentric reamer, allows a casing to follow the reamer as the hole is drilled. When completion depth is reached, the drill stem, percussion hammer, and reamer are pulled through the casing, and the casing then is pulled from the borehole. However, during the process of pulling the casing at the Cajon site, the 6-inch steel casing ruptured, leaving the hole cased from 184 to $262 \mathrm{ft}$ below land surface (on the basis of caliper measurements). The entire length of this unrecovered casing was perforated in place, at 3 -inch intervals with eight $11 / 2$-inch by 3/16-inch vertical slots spaced equidistant around the casing. These perforations, which constitute slightly less than 2 percent of the casing's surface area, allow for the exchange of moisture between the unsaturated zone (saturated zone at the deepest lysimeter prior to decline of the water table below $257 \mathrm{ft}$ after 1990) and the three lysimeters installed within the casing at depths of 199, 243, and $257 \mathrm{ft}$.

Suction lysimeters were installed at several depths in at least one test hole (lysimeter hole) at each of the eight residential sites to monitor the movement and quality of wastewater in the unsaturated zone (table 4). At six of the eight sites, lysimeter holes were drilled within about $5 \mathrm{ft}$ of the seepage pits. At two of the new-residence sites (Toltec and Vasquez), the hole was drilled through the bottom of the (as-yet-unused) seepage pit. At Cheyenne-I and Choctaw, a second test hole for installation of suction lysimeters was drilled 25 and $50 \mathrm{ft}$, respectively, from the seepage pit to ascertain possible lateral movement of wastewater. The suction lysimeters within each test hole were isolated from one another by backfilling the annulus with alternating layers of native material and bentonite powder. The suction lysimeter's porous ceramic cup was encased in silica flour to provide a clean transmission medium for soil water entering the porous cup, to enhance hydraulic contact between the adjoining soil and the cup, and to help prevent clogging of the porous cup by colloids, organic matter, or soil particles (Parizek and Lane, 1970). Typical suction lysimeters and their installation are shown in figure $10 A, B$.

Suction lysimeters consist of a porous ceramic cup that is attached to a polyvinyl chloride pipe that is connected to land surface by two access tubes (fig. 10C). Two types of suction lysimeters, each about $2 \mathrm{ft}$ long, $1.9 \mathrm{in}$. in diameter, and having a nominal pore size of $1.4 \mu \mathrm{m}$, were used for this study: (1) single chamber (for installation depths less than 50 $\mathrm{ft}$ below land surface), and (2) double chamber (for installation depths greater than $50 \mathrm{ft}$ ). Many of the single-chamber lysimeters, as indicated in table 4 , were damaged before the study was completed. A possible explanation for the high failure rate of the single-chamber lysimeters is that excess pressure was applied to the access tubes during sampling, resulting in separation of the tubes from the lysimeter. If single-chamber lysimeters are installed at depths greater than $50 \mathrm{ft}$ below land surface, a substantial proportion of the collected sample is forced back into the soil by the high air pressures necessary to force the collected sample to the surface. The doublechamber lysimeter incorporates two check valves that prevent pressurization of the porous cup. The check valves allow water to flow from the soil through the porous cup and into the upper chamber when a vacuum is applied. When pressure is applied to collect the sample, the lower check valve prevents the sample from entering the porous cup.

At four of the sites (Toltec, Vasquez, Little Beaver, and Cheyenne-II), a test hole (neutron-logging hole) was drilled within $5 \mathrm{ft}$ of the seepage pit for installation of a 2-inch galvanized-steel access tube, which was used for measuring moisture content by neutron logging. The annular space was backfilled with native material and with a 2- to 3-foot plug of bentonite powder opposite clay-rich zones.

A summary of monitoring devices installed and analyses completed at each study site is given in table 5 .

\section{ANALYSIS OF SOIL CORES AND PORE WATER}

Core material from the upper part of the splitspoon core barrel was placed in a plastic bag, airdried for several days, then stored for later analysis of grain size. Material from the lower part of the splitspoon core barrel was taken for determination of moisture content and for selected chemical and bacterial analyses.

\section{PHYSICAL ANALYSES}

Color, lithology, and qualitative indications of moisture content were determined by field inspection 
Table 4. Suction-lysimeter depth and lateral distance from seepage pit

[USGS site identification No.: A unique number for each site based on the latitude and longitude of the site. The first six digits are latitude, the next seven digits are longitude, and the final two digits are a sequence number to uniquely identify test holes and (or) depth of monitoring device at each residential site. ft, foot]

\begin{tabular}{|c|c|c|c|c|}
\hline $\begin{array}{c}\text { Site } \\
\text { name }\end{array}$ & $\begin{array}{l}\text { USGS site } \\
\text { identification } \\
\text { No. }\end{array}$ & $\begin{array}{l}\text { Depth of } \\
\text { suction } \\
\text { lysimeter } \\
(\mathrm{ft})\end{array}$ & $\begin{array}{l}\text { Lateral } \\
\text { distance from } \\
\text { seepage pit } \\
\text { (ft) }\end{array}$ & Remarks \\
\hline Toltec & $\begin{array}{r}342655117111401 \\
02 \\
03 \\
04\end{array}$ & $\begin{array}{l}73 \\
50 \\
40 \\
33\end{array}$ & $\begin{array}{l}0 \\
0 \\
0 \\
0\end{array}$ & $\begin{array}{l}\text { Destroyed 5-4-90. } \\
\text { Do. } \\
\text { Do. } \\
\text { Do. }\end{array}$ \\
\hline Cheyenne-I & $\begin{array}{r}343125117121501 \\
08 \\
02 \\
09 \\
10 \\
04 \\
11 \\
03\end{array}$ & $\begin{array}{l}113 \\
106 \\
92.5 \\
73 \\
63 \\
48 \\
42 \\
37\end{array}$ & $\begin{array}{r}5 \\
5 \\
5 \\
5 \\
5 \\
25 \\
5 \\
5\end{array}$ & $\begin{array}{l}\text { First hole, drilled 4-9-88; destroyed 1-11-90. } \\
\text { Second hole, drilled 12-6-88; destroyed 1-11-90. } \\
\text { First hole } \\
\text { Second hole } \\
\quad \text { Do. } \\
\text { Lateral flow hole; no water; destroyed 1-11-90. } \\
\text { Second hole } \\
\text { First hole }\end{array}$ \\
\hline Vasquez & $\begin{array}{r}343314117195201 \\
02 \\
03 \\
04\end{array}$ & $\begin{array}{l}71 \\
51 \\
43 \\
35\end{array}$ & $\begin{array}{l}0 \\
0 \\
0 \\
0\end{array}$ & $\begin{array}{l}\text { No water after 6-8-88: damaged. } \\
\text { No water after 8-23-89. }\end{array}$ \\
\hline Choctaw & $\begin{array}{r}343124117143001 \\
02 \\
03 \\
04 \\
05\end{array}$ & $\begin{array}{r}131 \\
80 \\
48 \\
33 \\
48\end{array}$ & $\begin{array}{r}5 \\
5 \\
5 \\
5 \\
50\end{array}$ & $\begin{array}{l}\text { No water after } 10-14-88 \text { : damaged. } \\
\text { No water after 1-27-89: damaged. } \\
\text { Lateral-flow hole; never yielded water. }\end{array}$ \\
\hline Little Beaver & 342857117120604 & $\begin{array}{l}67 \\
40 \\
31.5\end{array}$ & $\begin{array}{l}5 \\
5 \\
5\end{array}$ & $\begin{array}{l}\text { Suction lysimeter in hole with neutron-probe } \\
\text { access tube; only yielded water last time sampled } \\
(1-11-90) \text {. } \\
\text { Suction lysimeter in hole with neutron-probe } \\
\text { access tube; only yielded water once. }\end{array}$ \\
\hline Kiowa & $\begin{array}{r}342917117122601 \\
02 \\
03 \\
04\end{array}$ & $\begin{array}{l}149 \\
107.5 \\
67.5 \\
32\end{array}$ & $\begin{array}{l}5 \\
5 \\
5 \\
5\end{array}$ & $\begin{array}{l}\text { Sample volumes small. } \\
\text { No water after 10-14-88: damaged. } \\
\text { No water after 3-6-89: possibly damaged. }\end{array}$ \\
\hline Cheyenne-II & $\begin{array}{r}343114117122302 \\
03 \\
04\end{array}$ & $\begin{array}{l}98 \\
67 \\
10\end{array}$ & $\begin{array}{l}5 \\
5 \\
5\end{array}$ & $\begin{array}{l}\text { Never yielded water: damaged on installation. } \\
\text { Above active water level in seepage pit; never } \\
\text { yielded water. }\end{array}$ \\
\hline Cajon & $\begin{array}{r}342518117160601 \\
02 \\
03 \\
04 \\
05 \\
06 \\
07 \\
08\end{array}$ & $\begin{array}{l}257 \\
243 \\
199 \\
160 \\
130 \\
97.5 \\
70 \\
35\end{array}$ & $\begin{array}{l}5 \\
5 \\
5 \\
5 \\
5 \\
5 \\
5 \\
5\end{array}$ & $\begin{array}{l}\text { Only two samples. } \\
\text { Only two samples. } \\
\text { Only one sample (1-11-90). } \\
\text { Only two samples. }\end{array}$ \\
\hline
\end{tabular}




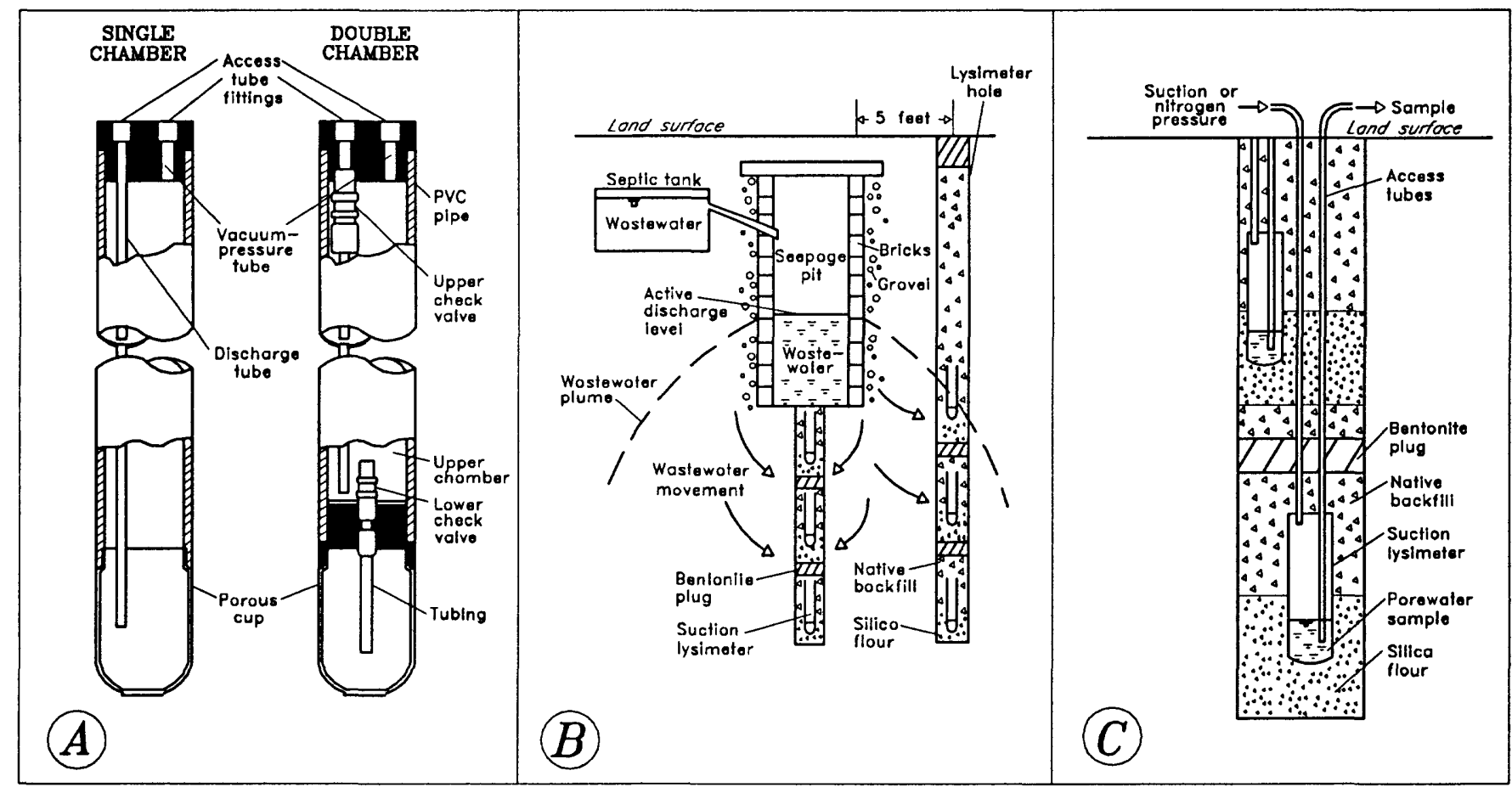

Figure 10. Diagrams showing (A) typical suction lysimeters, (B) installation, and (C) sampling method.

as the cores were recovered. Subsamples were dried and placed in resealable plastic bags for later analysis of grain size. Grain-size analyses were done according to methods described by American Society for Testing and Materials (1988, p. 87-93). Sieves were used for the sand and gravel fractions, and hydrometers were used for the clay and silt fractions. Results of these grain-size analyses for the eight residential sites are given in table 6 (and shown graphically in figures 12 and 13 later in this report).

Gravimetric moisture content of core material was determined by comparing the original weight of the sample (approximately 100 grams) with its dry weight (dried to a constant weight at 100 to $105^{\circ} \mathrm{C}$ for 12 to 18 hours). Measured moisture contents, expressed in percent of wet sample weight, are given in table 7 . Variability in determinations of moisture-content results from natural inhomogeneity and from moisture loss in the field, even during brief exposure of the core material to the high winds and very low humidity common in the study area, prior to weighing the soil (especially for those samples with very low moisture content). Five subsamples of a core collected from 67 to $69 \mathrm{ft}$ in the neutron hole at Vasquez demonstrate this variability: Measured moisture contents range from 12.1 to 16.5 percent (the mean value of 15.5 percent is given in table 7 ).

\section{CHEMICAL ANALYSES}

Core extracts for determination of pore-water (or interstitial-water) chemistry were prepared by adding $300-\mathrm{mL}$ of deionized water to approximately $100 \mathrm{~g}$ wet weight of core material. The relative proportion of water and soil used in the extraction was a compromise between use of enough water to permit processing and chemical analysis, but not so much water as to cause detection problems from excessive dilution. This soil-and-water mixture was placed in a polypropylene centrifuge tube with screw-top cap and agitated vigorously on a wrist-action shaker for about 30 minutes, then centrifuged for 1 hour at 5,000 revolutions per minute (producing a centrifugal force of 5,000 times gravity). The resulting liquid "extract" contains diluted pore water plus any soluble salts (minerals) and exchangeable cations extracted (leached) from the solid phase.

The extract was analyzed for specific conductance and $\mathrm{pH}$ in the field laboratory and for ammonia, nitrate, chloride, boron, and total alkalinity at the USGS National Water Quality Laboratory in Arvada, Colorado, using methods described by Fishman and Friedman (1989). The results of these analyses are given as computed pore-water concentration in table 7 (and in figure 13 presented later). Pore-water con- 
Table 5. Summary of monitoring devices installed and analyses completed at each study site

[Site: T, Toltec; C-I, Cheyenne-I; V, Vasquez; Ch, Choctaw; LB, Little Beaver; K, Kiowa; C-II, Cheyenne-II; Ca, Cajon; AR, Apple Ranchos; Ri, Rincon]

\begin{tabular}{|c|c|c|c|c|c|c|c|c|c|c|}
\hline & $\mathrm{T}$ & C-I & V & $\mathrm{Ch}$ & LB & $\mathbf{K}$ & C-II & $\mathrm{Ca}$ & AR & $\mathrm{Ri}$ \\
\hline \multicolumn{11}{|c|}{ Monitoring devices } \\
\hline Lysimeter at seepage pit & $\mathrm{X}$ & $\mathrm{X}$ & $\mathrm{X}$ & $X$ & $\mathrm{X}$ & $\mathrm{X}$ & $X$ & $\mathrm{X}$ & & \\
\hline Lateral-flow lysimeter & & $\mathrm{X}$ & & $\mathrm{X}$ & & & & & & \\
\hline Piezometer & & $\left({ }^{1}\right)$ & & $\left({ }^{1}\right)$ & & & $\left({ }^{1}\right)$ & $\left({ }^{2}\right)$ & $\mathrm{X}$ & $\mathrm{X}$ \\
\hline Neutron-access tube & $\mathrm{X}$ & & $\mathrm{X}$ & & $\mathrm{X}$ & & $X$ & & & \\
\hline
\end{tabular}

Analyses

Grain-size distribution in soil cores

Moisture content in soil cores

Fecal coliform in soil

Nitrifying bacteria in soil

Nitrate-reducing bacteria in soil

Total bacteria in soil

Soil extract, inorganic, chemical constituents

Soil, organic priority pollutants

Wastewater, inorganic, chemical constituents

Wastewater, organic priority pollutants

Wastewater, bacteria

Nitrogen isotopes

Tapwater, chemical constituents

$\begin{array}{cccccccc}\mathrm{X} & \mathrm{X} & \mathrm{X} & & \mathrm{X} & \mathrm{X} & \mathrm{X} & \mathrm{X} \\ \mathrm{X} & \mathrm{X} & \mathrm{X} & \mathrm{X} & \mathrm{X} & \mathrm{X} & \mathrm{X} & \mathrm{X} \\ & \mathrm{X} & & & & & & \mathrm{X} \\ & \mathrm{X} & & & & & & \mathrm{X} \\ & \mathrm{X} & & & & & & \mathrm{X}\end{array}$

${ }^{1}$ Bottom lysimeter below water table.

${ }^{2}$ Piezometer above declining water table after late 1991.

centrations are computed from the measured concentrations in the extracts using the equation:

$$
C_{p}=C_{e} \frac{W+W_{p}}{W_{p}},
$$

where

$C_{p}$ is the computed concentration in the pore water,

$W$ is the weight of deionized water used in extraction,

$W_{p}$ is the weight of pore water held by the soil sample, and

$C_{e}$ is the measured concentration in the extract solution.

The large dilution that results during extraction leads to substantial uncertainty in computed porewater concentrations, especially for those samples with very low moisture content. Additional sources of error are in the measurement of soil moisture and chemical analyses, along with natural inhomogeneity between subsamples (discussed previously). (See Feltz and others, 1985, and Fishman and Friedman, 1989, for general information on analytical precision and detection limits.) A quantitative assessment of precision in computed pore-water concentrations was not attempted for this study, and the precision is likely to be quite variable (depending on soil texture, soil moisture, and chemical concentrations). However, semi-quantitative evaluation of the sources listed above, and qualitative comparison to data obtained from lysimeters and from core extracts at adjacent depths, yields an overall uncertainty estimated to range from about 30 to about 50 percent.

In addition to the dilution errors described above, there is some ambiguity in interpretation of porewater concentrations for sparingly soluble constit- 
Table 6. Grain-size distribution for core samples at study sites

[ft, foot; --, no data; <, actual value is less than value shown. Particle-size descriptions are based on Wentworth scale]

\begin{tabular}{|c|c|c|c|c|c|c|}
\hline \multicolumn{7}{|c|}{ Percent finer than size, in millimeters, indicated } \\
\hline $\begin{array}{l}\text { Depth } \\
\text { interval } \\
\text { (ft) }\end{array}$ & $\begin{array}{c}\begin{array}{c}\text { Coarse } \\
\text { sand }\end{array} \\
2\end{array}$ & $\begin{array}{c}\begin{array}{c}\text { Medium } \\
\text { sand }\end{array} \\
0.5\end{array}$ & $\begin{array}{l}\begin{array}{l}\text { Fine } \\
\text { sand }\end{array} \\
0.25\end{array}$ & $\frac{\text { Silt }}{0.0625}$ & \multicolumn{2}{|c|}{ Clay } \\
\hline \multicolumn{7}{|c|}{ Toltec site (lysimeter hole)--April 7, 1988} \\
\hline $\begin{array}{l}33.5-34 \\
34-34.6 \\
37.3-37.7 \\
37.7-38 \\
37.8-38.6 \\
41.8-42.5 \\
42.5-43 \\
46.7-48.3 \\
48.4-49 \\
72.5-73.5\end{array}$ & $\begin{array}{r}93 \\
100 \\
100 \\
100 \\
100 \\
100 \\
70 \\
77 \\
80 \\
83\end{array}$ & $\begin{array}{c}63 \\
74 \\
65 \\
41 \\
40 \\
47 \\
-- \\
-- \\
-- \\
--\end{array}$ & $\begin{array}{r}45 \\
52 \\
46 \\
21 \\
21 \\
27 \\
9 \\
17 \\
11 \\
7\end{array}$ & $\begin{array}{c}31 \\
25 \\
27 \\
13 \\
12 \\
15 \\
-- \\
-- \\
-- \\
--\end{array}$ & $\begin{array}{l}6 \\
7 \\
7 \\
4 \\
3 \\
5 \\
4 \\
5 \\
3 \\
1\end{array}$ & $\begin{array}{l}3 \\
2 \\
3 \\
2 \\
1 \\
3 \\
3 \\
4 \\
3 \\
1\end{array}$ \\
\hline
\end{tabular}

\begin{tabular}{lrrrrrr}
\hline \multicolumn{7}{c}{ Toltec site (neutron-access hole)--April 7-8, 1988 } \\
\hline $32-33$ & 91 & 71 & 55 & 34 & 10 & 6 \\
$57-58.5$ & 64 & 24 & 14 & 7 & 2 & $<1$ \\
$67-68$ & 78 & 34 & 19 & 8 & 1 & $<1$ \\
$77-78$ & 71 & 33 & 25 & 20 & 2 & $<1$ \\
$87-88$ & 67 & 30 & 18 & 7 & 2 & $<1$ \\
$97-99$ & 100 & 88 & 45 & 7 & 2 & $<1$ \\
\hline
\end{tabular}

\begin{tabular}{|c|c|c|c|c|c|c|}
\hline \multicolumn{7}{|c|}{ Cheyenne-I site (first lysimeter hole)--April 9, 1988} \\
\hline $7-9$ & 100 & 82 & 58 & 19 & $<1$ & $<1$ \\
\hline $12-14$ & 94 & 73 & 43 & 8 & 1 & $<1$ \\
\hline $17-19$ & 90 & 40 & 17 & 3 & 1 & $<1$ \\
\hline $22-24$ & 100 & 90 & 77 & 29 & 3 & 2 \\
\hline $27-28$ & 100 & 87 & 60 & 15 & 4 & 2 \\
\hline $32-34$ & 98 & 80 & 54 & 9 & 2 & $<1$ \\
\hline $37-39$ & 87 & 84 & 78 & 50 & 7 & 6 \\
\hline $42-44$ & 100 & 89 & 63 & 23 & 5 & 4 \\
\hline $47-49$ & 85 & 69 & 57 & 38 & 12 & 7 \\
\hline $57-59$ & 78 & 30 & 11 & 3 & $<1$ & $<1$ \\
\hline $67-69$ & 81 & 32 & 15 & 6 & 1 & $<1$ \\
\hline $77-79$ & 99 & 98 & 81 & 54 & 13 & 1 \\
\hline 87.89 & 84 & 33 & 13 & 4 & $<1$ & $<1$ \\
\hline $97-99$ & 96 & 72 & 53 & 32 & 10 & 4 \\
\hline $107-109$ & 100 & 87 & 78 & 49 & 11 & 3 \\
\hline $118-120$ & 100 & 49 & 28 & 12 & 2 & $<1$ \\
\hline 124 & 100 & 78 & 43 & 8 & 1 & $<1$ \\
\hline \multicolumn{7}{|c|}{ Cheyenne-I site (lateral-flow hole)--April 10, 1988} \\
\hline $27-29$ & 99 & 94 & 82 & 33 & 4 & 2 \\
\hline $37-39$ & 99 & 98 & 96 & 62 & 12 & 8 \\
\hline $47-49$ & 99 & 82 & 68 & 48 & 7 & 5 \\
\hline \multicolumn{7}{|c|}{ Vasquez site (lysimeter hole)--April 11, 1988} \\
\hline $36-38$ & 55 & 22 & 10 & 7 & 2 & $<1$ \\
\hline $41-43$ & 94 & 49 & 20 & 4 & 2 & $<1$ \\
\hline $46-48$ & 92 & 56 & 19 & 8 & 3 & $<1$ \\
\hline $51-53$ & 94 & 64 & 45 & 30 & 7 & 4 \\
\hline $61-63$ & 89 & 50 & 35 & 22 & 6 & 3 \\
\hline $71-73$ & 99 & 92 & 81 & 48 & 12 & 7 \\
\hline
\end{tabular}


Table 6. Grain-size distribution for core samples at study sites-Continued

\begin{tabular}{|c|c|c|c|c|c|c|}
\hline \multicolumn{7}{|c|}{ Percent finer than size, in millimeters, indicated } \\
\hline \multirow{2}{*}{$\begin{array}{l}\text { Depth } \\
\text { interval } \\
\text { (ft) }\end{array}$} & \multirow{2}{*}{$\begin{array}{c}\begin{array}{c}\text { Coarse } \\
\text { sand }\end{array} \\
2\end{array}$} & \multirow{2}{*}{$\begin{array}{c}\begin{array}{c}\text { Medium } \\
\text { sand }\end{array} \\
0.5\end{array}$} & \multirow{2}{*}{$\begin{array}{l}\begin{array}{l}\text { Fine } \\
\text { sand }\end{array} \\
0.25\end{array}$} & \multirow{2}{*}{$\frac{\text { Silt }}{0.0625}$} & \multicolumn{2}{|c|}{ Clay } \\
\hline & & & & & 0.002 & 0.0014 \\
\hline \multicolumn{7}{|c|}{ Vasquez site (neutron hole)--April 12, 1988} \\
\hline $7-9$ & 98 & 89 & 76 & 39 & 6 & 3 \\
\hline $17-19$ & 89 & 34 & 11 & 3 & 2 & $<1$ \\
\hline $27-29$ & 100 & 98 & 95 & 64 & 4 & 2 \\
\hline $37-39$ & 64 & 19 & 9 & 6 & 3 & $<1$ \\
\hline $47-49$ & 98 & 84 & 50 & 7 & $<1$ & $<1$ \\
\hline $57-59$ & 98 & 76 & 67 & 53 & 5 & 3 \\
\hline $67-69$ & 98 & 78 & 56 & 37 & 4 & 2 \\
\hline $77-78$ & 98 & 83 & 69 & 41 & 2 & 1 \\
\hline $87-89$ & 89 & 39 & 18 & 7 & 1 & $<1$ \\
\hline
\end{tabular}

\begin{tabular}{|c|c|c|c|c|c|c|}
\hline \multicolumn{7}{|c|}{ Choctaw site (lysimeter hole)--April 13, 1988} \\
\hline $3-5$ & 97 & 74 & 54 & 17 & $<1$ & $<1$ \\
\hline $8-10$ & 95 & 57 & 34 & 8 & $<1$ & $<1$ \\
\hline $13-15$ & 89 & 34 & 10 & 2 & $<1$ & $<1$ \\
\hline $18-20$ & 99 & 87 & 69 & 25 & 1 & 1 \\
\hline $23-25$ & 100 & 98 & 91 & 30 & 4 & $<1$ \\
\hline $28-30$ & 99 & 94 & 86 & 55 & 5 & 2 \\
\hline $33-35$ & 94 & 74 & 54 & 25 & 3 & 2 \\
\hline $38-40$ & 99 & 81 & 54 & 27 & 2 & 1 \\
\hline $43-45$ & 87 & 38 & 22 & 7 & 2 & 2 \\
\hline $48-50$ & 100 & 97 & 85 & 36 & 5 & 4 \\
\hline $53-55$ & 97 & 70 & 44 & 23 & 5 & $<1$ \\
\hline $63-65$ & 91 & 45 & 18 & 7 & 2 & $<1$ \\
\hline $73-75$ & 96 & 72 & 50 & 26 & 6 & 5 \\
\hline $83-85$ & 97 & 82 & 66 & 34 & 6 & 4 \\
\hline $93-95$ & 66 & 33 & 16 & 4 & 1 & $<1$ \\
\hline $103-105$ & 77 & 26 & 11 & 3 & 1 & 1 \\
\hline $113-114$ & 96 & 79 & 66 & 35 & 8 & 7 \\
\hline $114-115$ & 94 & 62 & 30 & 6 & 1 & $<1$ \\
\hline $123-125$ & 98 & 77 & 69 & 59 & 18 & 13 \\
\hline
\end{tabular}

\begin{tabular}{rrrrrrr}
\hline \multicolumn{7}{c}{ Little Beaver site (lysimeter hole)--April 23, 1988 } \\
\hline $17-19$ & 82 & 34 & 14 & 6 & 2 & 2 \\
$27-29$ & 95 & 93 & 90 & 37 & 3 & $<1$ \\
$37-39$ & 91 & 89 & 86 & 51 & 4 & 2 \\
$47-49$ & 92 & 82 & 74 & 45 & 14 & 3 \\
$57-59$ & 91 & 74 & 59 & 32 & 13 & 4 \\
$77-79$ & 100 & 100 & 97 & 58 & 3 & 2 \\
$97-99$ & 91 & 81 & 71 & 39 & 6 & 3 \\
\hline
\end{tabular}

\begin{tabular}{crccccc}
\hline \multicolumn{7}{c}{ Kiowa site (lysimeter hole)--April 25, 1988 } \\
\hline $7-9$ & 58 & 26 & 14 & 7 & 3 & $<1$ \\
$12-14$ & 77 & 35 & 14 & 4 & 2 & $<1$ \\
$17-19$ & 99 & 93 & 65 & 14 & 2 & $<1$ \\
$22-24$ & 100 & 99 & 96 & 34 & 3 & $<1$ \\
$27-29$ & 100 & 97 & 90 & 53 & 4 & 2
\end{tabular}


Table 6. Grain-size distribution for core samples at study sites--Continued

\begin{tabular}{|c|c|c|c|c|c|c|}
\hline \multicolumn{7}{|c|}{ Percent finer than size, in millimeters, indicated } \\
\hline \multirow{2}{*}{$\begin{array}{l}\text { Depth } \\
\text { interval } \\
(\mathrm{ft})\end{array}$} & \multirow{2}{*}{$\begin{array}{c}\begin{array}{c}\text { Coarse } \\
\text { sand }\end{array} \\
2\end{array}$} & \multirow{2}{*}{$\frac{\begin{array}{c}\text { Medium } \\
\text { sand }\end{array}}{0.5}$} & \multirow{2}{*}{$\begin{array}{c}\begin{array}{c}\text { Fine } \\
\text { sand }\end{array} \\
0.25\end{array}$} & \multirow{2}{*}{$\frac{\text { Silt }}{0.0625}$} & \multicolumn{2}{|c|}{ Clay } \\
\hline & & & & & 0.002 & 0.0014 \\
\hline \multicolumn{7}{|c|}{ Kiowa site (lysimeter hole)--April 25, 1988--Continued } \\
\hline $32-34$ & 99 & 87 & 55 & 19 & 3 & $<1$ \\
\hline $37-39$ & 87 & 52 & 37 & 15 & 2 & $<1$ \\
\hline $42-44$ & 95 & 66 & 45 & 23 & 4 & $<1$ \\
\hline $47-49$ & 100 & 94 & 78 & 24 & 4 & $<1$ \\
\hline $57-59$ & 100 & 100 & 97 & 44 & 3 & $<1$ \\
\hline $67-69$ & 98 & 86 & 78 & 64 & 13 & 7 \\
\hline $77-79$ & 93 & 74 & 62 & 19 & 2 & $<1$ \\
\hline $87-89$ & 77 & 39 & 22 & 10 & 5 & $<1$ \\
\hline $97-99$ & 97 & 82 & 69 & 46 & 7 & 4 \\
\hline $117-119$ & 96 & 89 & 84 & 63 & 14 & 7 \\
\hline $127-129$ & 94 & 76 & 65 & 31 & 5 & 2 \\
\hline $137-139$ & 96 & 82 & 64 & 31 & 17 & 4 \\
\hline $147-149$ & 90 & 50 & 23 & 9 & 2 & $<1$ \\
\hline \multicolumn{7}{|c|}{ Cheyenne-II site (neutron-access hole)--April 27, 1988} \\
\hline $7-9$ & 100 & 88 & 61 & 14 & 2 & 2 \\
\hline $17-19$ & 85 & 60 & 47 & 22 & 2 & 2 \\
\hline $22-24$ & 94 & 87 & 80 & 22 & 5 & 4 \\
\hline $27-29$ & 96 & 39 & 17 & 3 & 2 & $<1$ \\
\hline $32-34$ & 92 & 29 & 11 & 3 & 1 & $<1$ \\
\hline $37-39$ & 100 & 98 & 94 & 37 & 7 & 3 \\
\hline $42-44$ & 91 & 78 & 42 & 9 & 3 & 1 \\
\hline $47-49$ & 100 & 97 & 94 & 63 & 11 & 7 \\
\hline $57-59$ & 95 & 73 & 58 & 41 & 13 & 9 \\
\hline $67-69$ & 100 & 95 & 79 & 39 & 8 & 5 \\
\hline $77-79$ & 80 & 32 & 23 & 8 & 4 & 3 \\
\hline $87-89$ & 99 & 92 & 82 & 44 & 6 & 4 \\
\hline $97-99$ & 79 & 41 & 30 & 14 & 4 & 3 \\
\hline \multicolumn{7}{|c|}{ Cajon site (lysimeter hole)--November 29, 1988} \\
\hline $82-84$ & 93 & 46 & 27 & 13 & 5 & $<1$ \\
\hline $101-103$ & 86 & 56 & 36 & 18 & 8 & 7 \\
\hline $121-123$ & 100 & 91 & 47 & 20 & 8 & 7 \\
\hline $140.5-142.5$ & 98 & 78 & 52 & 19 & 8 & 8 \\
\hline $160.5-162.5$ & 92 & 43 & 24 & 9 & 3 & $<1$ \\
\hline $180.5-182.5$ & 78 & 35 & 19 & 7 & $<1$ & $<1$ \\
\hline $200.5-202.5$ & 62 & 36 & 23 & 9 & 4 & 1 \\
\hline $220-222$ & 81 & 54 & 36 & 14 & 4 & 3 \\
\hline $240-242$ & 83 & 40 & 22 & 8 & 3 & 3 \\
\hline
\end{tabular}


Table 7. Moisture content and pore-water chemical concentration determined from cores at residential study sites

[Chemical concentrations calculated from analyses on deionized-water extracts using known quantities of core material, except $\mathrm{pH}$ reported from extract analyses directly; $\mathrm{mg} / \mathrm{L}$, milligram per liter; $\mu \mathrm{S} / \mathrm{cm}$, microsiemen per centimeter at 25 degrees Celsius; <, less than reporting limit; ND, not detected; --, not analyzed]

\begin{tabular}{|c|c|c|c|c|c|c|c|c|c|}
\hline $\begin{array}{l}\text { Core depth } \\
\text { interval (in } \\
\text { feet below } \\
\text { land surface }\end{array}$ & $\begin{array}{l}\text { Moisture } \\
\text { content } \\
\text { (weight } \\
\text { percent) }\end{array}$ & $\begin{array}{c}\text { Nitrate/ } \\
\text { chloride } \\
\text { (weight } \\
\text { ratio) }\end{array}$ & $\begin{array}{c}\mathrm{pH} \\
\text { (standard } \\
\text { units) }\end{array}$ & $\begin{array}{c}\text { Specific } \\
\text { conductance } \\
(\mu \mathrm{S} / \mathrm{cm})\end{array}$ & $\begin{array}{l}\text { Ammonia } \\
\mathrm{NH}_{3}-\mathrm{N} \\
(\mathrm{mg} / \mathrm{L})\end{array}$ & $\begin{array}{l}\text { Nitrate } \\
\mathrm{NO}_{3}-\mathrm{N} \\
(\mathrm{mg} / \mathrm{L})\end{array}$ & $\begin{array}{c}\text { Chloride } \\
\text { (mg/L) }\end{array}$ & $\begin{array}{l}\text { Boron } \\
(\mathrm{mg} / \mathrm{L})\end{array}$ & $\begin{array}{c}\text { Total } \\
\text { alkalinity, } \\
\text { as } \mathrm{CaCO}_{3} \\
(\mathrm{mg} / \mathrm{L})\end{array}$ \\
\hline \multicolumn{10}{|c|}{ Toltec site (neutron-access hole)--April 7-8, 1988} \\
\hline $5-7$ & 1.85 & 0.017 & 7.9 & 18,000 & 1 & 40 & 2,400 & 4 & 3,000 \\
\hline $23-24$ & 4.15 & .10 & 7.0 & 13,000 & ND & 270 & 2,700 & 2 & 300 \\
\hline $32-33$ & 5.73 & .12 & 7.3 & 3,900 & ND & 89 & 750 & 1 & 400 \\
\hline $42-43$ & 3.38 & .062 & 7.5 & 2,100 & ND & 36 & 580 & 2 & 600 \\
\hline $57-58.5$ & 1.58 & .037 & 7.7 & 2,100 & -- & 14 & 380 & 2 & 1,100 \\
\hline $67-68$ & 2.23 & .034 & 7.9 & 1,500 & ND & 11 & 320 & 3 & 900 \\
\hline $77-78$ & 1.22 & .049 & 7.8 & 2,400 & 7 & 17 & 340 & 2 & 1,400 \\
\hline $87-88$ & 1.94 & .038 & 7.6 & 2,000 & -. & 8.9 & 240 & 3 & 1,000 \\
\hline $97-99$ & 5.96 & .049 & 7.7 & 610 & -- & 5.6 & 110 & 1 & 300 \\
\hline \multicolumn{10}{|c|}{ Cheyenne-I site (first lysimeter hole)--April 9, 1988} \\
\hline $7-9$ & 6.81 & 0.0024 & 9.0 & 22,000 & 1 & 11 & 4,800 & 9 & 2,700 \\
\hline $1-14$ & 3.58 & .0088 & 7.3 & 17,000 & 5 & 33 & 3,700 & 6 & 400 \\
\hline $17-19$ & 2.92 & -- & 7.9 & 4,200 & -- & 88 & -. & -- & -- \\
\hline $22-24$ & 9.60 & .28 & 7.4 & 1,500 & .6 & 58 & 210 & 10 & 300 \\
\hline $27-28$ & 12.10 & .025 & 9.0 & 2,200 & -- & 4.6 & 180 & 10 & 800 \\
\hline $32-34$ & 8.15 & -- & 7.2 & 2,100 & 3 & 52 & -- & -- & -- \\
\hline $37-39$ & 23.70 & .24 & 8.4 & 1,900 & -- & 29 & 120 & 13 & 600 \\
\hline $42-44$ & 13.70 & -- & 8.4 & 1,400 & -- & 40 & -- & -- & -- \\
\hline $47-49$ & 14.80 & -- & 8.9 & 2,900 & ND & 44 & -- & -- & -- \\
\hline $57-59$ & 3.30 & -- & 8.7 & 2,600 & -- & 56 & -- & -- & -- \\
\hline $67-69$ & 5.02 & .099 & 9.7 & 5,600 & ND & 55 & 550 & 18 & 2,500 \\
\hline $77-79$ & 22.30 & .16 & 8.6 & 2,900 & ND & 31 & 190 & 2 & 600 \\
\hline $87-89$ & 2.78 & -- & 7.3 & 2,600 & ND & 19 & -- & -- & -- \\
\hline $97-99$ & 23.00 & -. & 7.9 & 1,600 & 2 & .73 & -- & -. & -. \\
\hline $107-109$ & 18.40 & -- & 8.9 & 2,700 & .3 & .82 & -- & -- & -- \\
\hline $118-120$ & 17.50 & .011 & 7.7 & 1,400 & .5 & 2.0 & 180 & .5 & 150 \\
\hline
\end{tabular}

Cheyenne-I site (lateral-flow hole)--April 10, 1988

\begin{tabular}{ccrccrrrrr}
\hline $27-29$ & 14.0 & 0.11 & 8.4 & 4,500 & -- & 31 & 290 & 7 & 400 \\
$27-29$ & 14.0 & .11 & 8.7 & 4,800 & -- & 32 & 280 & 7 & 600 \\
$37-39$ & 30.7 & .28 & 8.4 & 4,300 & ND & 35 & 130 & 4 & 500 \\
$47-49$ & 12.3 & .19 & 8.5 & 2,400 & -- & 31 & 160 & 3 & 500 \\
$49-49.2$ & 15.3 & .18 & 8.7 & 2,500 & -- & 33 & 180 & 4 & 600 \\
\hline
\end{tabular}

Cheyenne-I site (second lysimeter hole)--December 6, 1988

\begin{tabular}{rcrllcllrr}
\hline $17-19$ & 12.7 & 0.11 & -- & 3,900 & 2 & 24 & 220 & 6 & 1,000 \\
$22-24$ & 13.1 & .18 & -- & 1,700 & .3 & 33 & 180 & 6 & 400 \\
$27-29$ & 13.2 & .26 & -- & 1,500 & .7 & 52 & 200 & 9 & 300 \\
$32-34$ & 3.87 & .12 & -- & 2,000 & 5 & 34 & 290 & 12 & 600 \\
$37-39$ & 32.8 & .21 & -- & 1,600 & ND & 22 & 100 & 8 & 500 \\
$42-44$ & 10.0 & .13 & -- & 1,500 & .09 & 27 & 200 & 11 & 300 \\
$47-49$ & 12.4 & .12 & -- & 1,600 & 1 & 25 & 210 & 15 & 300 \\
$52-53$ & 3.04 & .11 & -- & 2,000 & 1 & 36 & 350 & 14 & 600 \\
$62-64$ & 14.3 & .10 & -- & 1,500 & 1 & 22 & 220 & 12 & 400
\end{tabular}


Table 7. Moisture content and pore-water chemical concentration determined from cores at residential study sites--Continued

\begin{tabular}{|c|c|c|c|c|c|c|c|c|c|}
\hline $\begin{array}{l}\text { Core depth } \\
\text { interval (in } \\
\text { feet below } \\
\text { land surface }\end{array}$ & $\begin{array}{c}\text { Moisture } \\
\text { content } \\
\text { (weight } \\
\text { percent) }\end{array}$ & $\begin{array}{c}\text { Nitrate/ } \\
\text { chloride } \\
\text { (weight } \\
\text { ratio) } \\
\end{array}$ & $\begin{array}{c}\mathrm{pH} \\
\text { (standard } \\
\text { units) }\end{array}$ & $\begin{array}{c}\text { Specific } \\
\text { conductance } \\
(\mu \mathrm{S} / \mathrm{cm})\end{array}$ & $\begin{array}{c}\text { Ammonia } \\
\mathrm{NH}_{3}-\mathrm{N} \\
(\mathrm{mg} / \mathrm{L})\end{array}$ & $\begin{array}{l}\text { Nitrate } \\
\mathrm{NO}_{3}-\mathrm{N} \\
(\mathrm{mg} / \mathrm{L})\end{array}$ & $\begin{array}{l}\text { Chloride } \\
\text { (mg/L) }\end{array}$ & $\begin{array}{l}\text { Boron } \\
(\mathrm{mg} / \mathrm{L})\end{array}$ & $\begin{array}{c}\text { Total } \\
\text { alkalinity, } \\
\text { as } \mathrm{CaCO}_{3} \\
(\mathrm{mg} / \mathrm{L}) \\
\end{array}$ \\
\hline \multicolumn{10}{|c|}{ Cheyenne-I site (second lysimeter hole)--December 6, 1988--Continued } \\
\hline $67-69$ & 9.02 & .19 & -- & 1,500 & .5 & 36 & 180 & 12 & 300 \\
\hline $72-74$ & 14.2 & .1 & -- & 1,700 & .08 & 33 & 180 & 8 & 400 \\
\hline $77-79$ & 17.6 & .22 & -- & 1,600 & .04 & 35 & 160 & 3 & 300 \\
\hline $82-84$ & 8.04 & .033 & -- & 1,900 & .9 & 10 & 310 & .7 & 200 \\
\hline $87-89$ & 1.90 & .031 & -- & 400 & .5 & 2.1 & 68 & .3 & 100 \\
\hline $92-94$ & 13.1 & .067 & -- & 2,700 & .7 & 15 & 230 & .6 & 500 \\
\hline $97-99$ & 12.4 & .086 & -- & 1,700 & 2 & 18 & 210 & .8 & 200 \\
\hline \multicolumn{10}{|c|}{ Vasquez site (lysimeter hole)--April 11, 1988} \\
\hline $36-38$ & 4.21 & -- & -- & - & -- & -- & -- & -- &.- \\
\hline $41-43$ & 6.94 & -- & -- & -- & -- & -- & -- & -- & -- \\
\hline $46-48$ & 6.14 & -- & -- & -- & -- & -- & -- & -- & -- \\
\hline $51-53$ & 11.4 & -- & -- & -- & -- & -- & -- & -- & -- \\
\hline $61-63$ & 10.4 & -. & -- & -- & -- & -- & -- & -- & -- \\
\hline $71-73$ & 20.0 & -- & -- & -- & -- & -- & -- & -- & -- \\
\hline
\end{tabular}

Vasquez site (neutron hole)--April 12, 1988

\begin{tabular}{|c|c|c|c|c|c|c|c|c|c|}
\hline $7-9$ & 11.9 & -- & -- & -- & -- & -- & -- & -- & - \\
\hline $17-19$ & 1.00 & - & -- & -- & -- & -- & -- & -- & -- \\
\hline $27-29$ & 11.9 & -. & -- & -- & -- & -- & -- & -- & -- \\
\hline $37-39$ & 3.81 & - & -- & -- & -- & -- & -- & -- & -- \\
\hline $47-49$ & 7.05 & -- & -- & -- & -- & -- & -. & -- & -- \\
\hline $57-59$ & 10.3 & .. & -- & -- & -- & -- & -- & -- & -- \\
\hline $67-69$ & 15.5 & -- & -- & -- & -- & -- & -. & -- & -- \\
\hline $77-78$ & 16.1 & -- & -- & -- & -- & -- & -- & -- & -- \\
\hline $87-89$ & 5.21 & -- & -- & -- & -- & -- &.- & -. & -- \\
\hline
\end{tabular}

Choctaw site (lysimeter hole)--April 13, 1988

\begin{tabular}{cccccccccr}
\hline $3-5$ & 6.99 & 0.051 & 9.67 & 5,600 & 2 & 7.3 & 140 & 2 & 4,400 \\
$8-10$ & 9.37 & .38 & 8.72 & 2,900 & .6 & 40 & 110 & .8 & 1,200 \\
$13-15$ & 5.07 & .63 & 7.02 & 1,100 & \multicolumn{1}{l}{ ND } & 40 & 63 & 1 & 200 \\
$18-20$ & 12.4 & .026 & 7.50 & 820 & .7 & 2.2 & 82 & .7 & 300 \\
$23-25$ & 17.2 & .60 & 8.22 & 2,000 & ND & 22 & 37 & .4 & 900 \\
$28-30$ & 15.9 & .032 & 7.63 & 750 & 3 & 5.3 & 170 & 1 & 300 \\
$28-30$ & 15.9 & .11 & 7.64 & 660 & 7 & 6.0 & 53 & .9 & 200 \\
$28-30$ & 15.9 & .049 & 7.56 & 700 & 12 & 6.6 & 130 & 1 & 200 \\
$33-45$ & 7.31 & .0037 & 7.80 & 1,200 & -- & .49 & 130 & 1 & 600 \\
$38-40$ & 12.3 & .0079 & 7.95 & 1,400 &.- & .65 & 83 & 2 & 700 \\
$43-45$ & 2.97 & .014 & 7.46 & 2,700 & 3 & 2.7 & 200 & 3 & 700 \\
$48-50$ & 13.5 & .084 & 7.78 & 1,000 & .2 & 9.9 & 120 & 2 & 400 \\
$53-55$ & 10.4 & .12 & 9.11 & 2,500 & .5 & 15 & 120 & 3 & 1,400 \\
$63-65$ & 6.92 & .064 & 7.99 & 980 & -- & 7.4 & 110 & 7 & 400 \\
$73-75$ & 9.26 & .12 & 7.53 & 920 & .6 & 21 & 170 & 6 & 300 \\
$83-85$ & 12.1 &.- & 7.40 & 890 &.- & 20 & -- & 3 & 300 \\
$93-95$ & 4.24 & .10 & 7.45 & 1,400 &.- & 19 & 190 & 11 & 600 \\
$103-105$ & 5.14 & .15 & 7.19 & 1,000 & 2 & 16 & 110 & 4 & 400 \\
$113-115$ & 3.31 & .18 & 7.25 & 1,200 & 2 & 19 & 110 & 1 & 400 \\
$123-125$ & 19.8 & .0054 & 8.51 & 2,600 & .1 & .88 & 160 & .9 & 580
\end{tabular}


Table 7. Moisture content and pore-water chemical concentration determined from cores at residential study sites--Continued

\begin{tabular}{|c|c|c|c|c|c|c|c|c|c|}
\hline $\begin{array}{l}\text { Core depth } \\
\text { interval (in } \\
\text { feet below } \\
\text { land surface }\end{array}$ & $\begin{array}{l}\text { Moisture } \\
\text { content } \\
\text { (weight } \\
\text { percent) }\end{array}$ & $\begin{array}{c}\text { Nitrate/ } \\
\text { chloride } \\
\text { (weight } \\
\text { ratio) }\end{array}$ & $\begin{array}{c}\mathrm{pH} \\
\text { (standard } \\
\text { units) }\end{array}$ & $\begin{array}{c}\text { Specific } \\
\text { conductance } \\
(\mu \mathrm{S} / \mathrm{cm})\end{array}$ & $\begin{array}{l}\text { Ammonia } \\
\mathrm{NH}_{3}-\mathrm{N} \\
(\mathrm{mg} / \mathrm{L})\end{array}$ & $\begin{array}{l}\text { Nitrate } \\
\mathrm{NO}_{3}-\mathrm{N} \\
(\mathrm{mg} / \mathrm{L})\end{array}$ & $\begin{array}{c}\text { Chloride } \\
\text { (mg/L) }\end{array}$ & $\begin{array}{l}\text { Boron } \\
(\mathrm{mg} / \mathrm{L})\end{array}$ & $\begin{array}{c}\text { Total } \\
\text { alkalinity, } \\
\text { as } \mathrm{CaCO}_{3} \\
(\mathrm{mg} / \mathrm{L})\end{array}$ \\
\hline \multicolumn{10}{|c|}{ Little Beaver site (lysimeter hole)--April 23, 1988--Continued } \\
\hline $17-19$ & 2.57 & -- & -- & -- & -- & -- & -- & $\ldots$ & -- \\
\hline $27-29$ & 8.54 & -- & -- & -- & -- & -- & -- & -- & -- \\
\hline $37-39$ & 8.25 & -- & -. & -. & -- & -. & -- & -- & -- \\
\hline $47-49$ & 3.88 & -- & -. & -- & -.- & -. & -- & -- & -. \\
\hline $57-59$ & 11.8 & -- & -. & -- & -- & -- & -- & -- & -- \\
\hline $67-69$ & 6.13 & -- & -- & -- & -- & -- & -- & -- & -- \\
\hline \multicolumn{10}{|c|}{ Little Beaver site (neutron hole)--April 24, 1988} \\
\hline $77-79$ & 6.86 & -- & -- & .. & -.- & -- & -- & -- & -- \\
\hline $88-89$ & 15.1 & -- & -- & -- & -- & -- & -- & -- & -- \\
\hline $97-99$ & 6.87 & -- & -- & -- & -- & -- & -- & -- & -- \\
\hline \multicolumn{10}{|c|}{ Kiowa site (lysimeter hole)--April 25, 1988} \\
\hline $7-9$ & 4.35 & 0.082 & 7.51 & 120,000 & 5 & 34 & 420 & 4 & 1,200 \\
\hline $12-14$ & 3.52 & .049 & 9.37 & 9,400 & ND & 36 & 730 & 2 & 3,100 \\
\hline $17-19$ & 12.4 & .28 & 6.44 & 760 & 1 & 20 & 72 & .6 & 200 \\
\hline $22-24$ & 13.5 & -- & 6.90 & 1,200 & -- & 11 & -- & .4 & 100 \\
\hline $27-29$ & 15.5 & -- & 7.29 & 1,600 & .7 & 33 & -- & .6 & 200 \\
\hline $32-34$ & 17.0 & 1.1 & 7.47 & 950 & .3 & 42 & 38 & .7 & 200 \\
\hline $37-39$ & 7.26 & -- & 7.21 & 820 & -- & 3.6 & -- & 1 & 300 \\
\hline $42-44$ & 9.90 & .29 & 7.17 & 830 & ND & 23 & -- & .8 & 200 \\
\hline $47-49$ & 12.9 & -- & 7.95 & 1,500 & -- & 26 & -- & .9 & 500 \\
\hline $57-59$ & 18.7 & -- & 7.60 & 1,100 & -- & 19 & -- & .7 & 300 \\
\hline $67-69$ & 18.8 & -- & 7.84 & 610 & -- & 7.5 & -- & 2 & 200 \\
\hline $77-79$ & 14.5 & -- & 7.84 & 880 & -. & 15 & -- & .5 & 300 \\
\hline $87-89$ & 7.95 & -- & 7.38 & 750 & 1 & 16 & -- & .3 & 300 \\
\hline $97-99$ & 11.6 & .35 & 7.71 & 940 & -- & 22 & 62 & .4 & 400 \\
\hline $107-109$ & 13.8 & .0037 & 8.51 & 1,500 & -. & .73 & 200 & .8 & 100 \\
\hline $117-119$ & 15.7 & .. & 7.61 & 690 & -. & 20 & -- & 1 & 300 \\
\hline $127-129$ & 14.3 & -- & 7.37 & 570 & -- & -- & -- & -- & -- \\
\hline $137-139$ & 12.6 & -. & 8.64 & 2,500 & 3 & 27 & -- & .9 & 1,100 \\
\hline $148-149$ & 4.27 & $-\cdots$ & 8.17 & 1,300 & -- & 1 & -- & 2 & 600 \\
\hline \multicolumn{10}{|c|}{ Cheyenne-II site (neutron-access hole)--April 27, 1988} \\
\hline $7-9$ & 0.98 & 0.0096 & 8.25 & 44,000 & ND & 51 & 5,300 & 39 & 4,200 \\
\hline $12-14$ & 3.6 & .0037 & 8.28 & 33,000 & ND & 22 & 6,000 & 14 & 1,900 \\
\hline $17-19$ & 8.41 & .021 & 8.4 & 15,000 & ND & 43 & 2,100 & 6 & 1,400 \\
\hline $22-24$ & 11.1 & .24 & 8.7 & 4,400 & ND & 31 & 130 & 1 & 1,100 \\
\hline $27-29$ & 5.62 & .17 & 6.87 & 1,400 & .5 & 45 & 260 & .9 & 200 \\
\hline $32-34$ & 5.86 & .12 & 7.13 & 1,400 & .9 & 38 & 330 & -. & 300 \\
\hline $37-39$ & 24.6 & .45 & 7.87 & 1,600 & .2 & 52 & 120 & .9 & 300 \\
\hline $42-44$ & 8.35 & .37 & 8.76 & 1,900 & .7 & 92 & 250 & 1 & 600 \\
\hline $47-49$ & 20.1 & -- & 7.84 & 1,500 & .1 & 41 & -- & 1 & 400 \\
\hline $57-59$ & 15.6 & -- & 7.61 & 1,800 & -- & -- & 160 & 1 & 300 \\
\hline $67-69$ & 19.2 & .040 & 7.59 & 1,500 & .1 & 6.9 & 170 & .3 & 200 \\
\hline $77-79$ & 2.77 & .0023 & 6.96 & 2,200 & 4 & 1.3 & 570 & ND & 500 \\
\hline $87-89$ & 14.5 & -- & 7.38 & 1,600 & -. & .85 & -- & -- & -. \\
\hline $97-99$ & 7.11 & .0031 & 7.22 & 2,000 & .8 & 1.1 & 360 & 1 & 200 \\
\hline $107-109$ & 11.0 & .48 & 7.23 & 1,600 & ND & 24 & 50 & .5 & 700 \\
\hline $117-119$ & 13.3 & .036 & 7.44 & 1,900 & 2 & 9 & 250 & .8 & 200 \\
\hline
\end{tabular}


Table 7. Moisture content and pore-water chemical concentration determined from cores at residential study sites--Continued

\begin{tabular}{cccccccccc}
\hline $\begin{array}{l}\text { Core depth } \\
\text { interval (in } \\
\text { feet below } \\
\text { land surface }\end{array}$ & $\begin{array}{c}\text { Moisture } \\
\text { content } \\
\text { (weight } \\
\text { percent) }\end{array}$ & $\begin{array}{c}\text { Nitrate/ } \\
\text { chloride } \\
\text { (weight } \\
\text { ratio) }\end{array}$ & $\begin{array}{c}\mathrm{pH} \\
\text { (standard } \\
\text { units) }\end{array}$ & $\begin{array}{c}\text { Specific } \\
\text { conductance } \\
(\mu \mathrm{S} / \mathrm{cm})\end{array}$ & $\begin{array}{c}\mathrm{Ammonia}_{\mathrm{NH}_{3}-\mathrm{N}} \\
(\mathrm{mg} / \mathrm{L})\end{array}$ & $\begin{array}{c}\text { Nitrate } \\
\mathrm{NO}_{3}-\mathrm{N} \\
(\mathrm{mg} / \mathrm{L})\end{array}$ & $\begin{array}{c}\text { Chloride } \\
(\mathrm{mg} / \mathrm{L})\end{array}$ & $\begin{array}{c}\text { Boron } \\
(\mathrm{mg} / \mathrm{L})\end{array}$ & $\begin{array}{c}\text { Total } \\
\text { alkalinity, } \\
\text { as CaCO } \\
(\mathrm{mg} / \mathrm{L})\end{array}$ \\
\hline $27-29$ & \multicolumn{7}{c}{ Cheyenne-II site } \\
(lysimeter hole)--April 28, 1988 \\
$42-43$
\end{tabular}

uents. Highly soluble constituents, such as $\mathrm{NO}_{3}^{-}, \mathrm{Cl}^{-}$, and probably $\mathrm{B}$, are not affected by such considerations. However, $\mathrm{NH}_{4}^{+}$(ammonium) is strongly sorbed, especially by ion-exchange on clay minerals. Specific-conductance data from one core sample extracted with varying soil-to-water proportions (range was from $2: 1$ to $1: 4)$ revealed the additional dissolution of sparingly soluble minerals and (or) a shift in the relative proportion of major cations in the extract at the greater dilutions. Although alkalinity is presumed to be similarly affected, values of $\mathrm{pH}$ varied less than $0.1 \mathrm{pH}$ unit over this entire range of dilution.

Data for nitrate that are given in this report include the analysis of nitrate plus nitrite; however, because nitrite (a transient form of nitrogen that generally undergoes rapid biological transformation in nature) is present in quantities that are much less than the quantities of nitrate, results are referred to throughout this report simply as "nitrate."

\section{MICROBIOLOGICAL ANALYSES}

All microbiological analyses of core material and wastewater were done in the field laboratory, which was equipped with an autoclave, refrigerator, incubators, filtration apparatus, and microscope. Analyses included total heterotrophic bacteria (standard plate count), fecal coliform, and nitrifying and nitrate-respiring (including denitrifying) bacteria. Standard methods of analysis described by Britton and Greeson (1987) were used.

The stainless steel split-spoon core barrel was flame-sterilized prior to collection of each core. Exterior parts of the core that were in contact with the liner were removed with a sterile spatula, and a small quantity of soil from the interior was excised and placed in a sterile "whirl-pak" plastic bag. The bag was stored on ice or refrigerated until analyses were begun (usually within 6 hours of sample collection).

The membrane filtration (MF) method was used for analysis of total bacteria (standard plate count) and fecal coliform. Ten grams (wet weight) of soil was dispersed into $90 \mathrm{~mL}$ of sterile phosphate (with peptone) buffer. Six successive decimal (10x) dilutions (total dilution factor of $10^{-7}$ ) were prepared from the mixture to produce ideal plate counts. Aliquots of each dilution were assayed in triplicate. Cellulose acetate nitrate, $0.45-\mu \mathrm{m}$ membrane filters were incubated for enumeration of total bacteria on Standard Methods agar (extract of tryptone glucose yeast) [manufactured by BBL Microbiology Systems, Cockeysville, Maryland] at $30^{\circ} \mathrm{C}$ for 24 hours. Filters for fecal coliform were incubated on M-FC agar [manufactured by Millipore Corp., Bedford, Massachusetts] at $44.5^{\circ} \mathrm{C}$ for 24 hours. Total-bacteria and 
coliform counts are reported as CFU (colony-forming units) per gram of wet soil in table 8 . The data indicate widespread presence of heterotrophic bacteria but complete absence of fecal coliform in the soil beneath the seepage pits.

The presence of nitrifying and nitrate-respiring (a group of nitrate reducers that includes denitrifiers) bacteria was determined for core samples from two test holes, at Cheyenne-I and Cajon. A three-tube MPN (most probable number) method was used with five order-of-magnitude decimal dilution aliquots inoculated. An ammonium calcium carbonate medium and a nitrite calcium carbonate medium were used for the Nitrosomonas and Nitrobacter groups of nitrifying bacteria, respectively. Nitrate-broth medium was used for the nitrate-respiring bacterial group. Ten grams of wet soil was dispersed in a dilution blank containing 95-mL of deionized water and glass beads, and from this mixture successive decimal dilutions (to a dilution factor of $10^{-6}$ ) were prepared with deionized water. Culture tubes containing appropriate media were inoculated with an aliquot from each dilution series, and an additional tube of medium was set aside as a control. Results are reported in table 9 as MPN per gram of wet soil with 95-percent confidence interval based on positive and negative results from three 1-, three 0.1-, and three 0.01-milliliter dilutions from each dilution series.

\section{IN SITU MONITORING IN THE UNSATURATED ZONE}

\section{SOIL-MOISTURE CONTENT}

Periodic monitoring of soil-moisture content beneath the seepage pits at four sites was done using a neutron-logging instrument. The instrument measures the attenuation of neutrons by hydrogen atoms in water as a neutron source is lowered down the access tube. Moisture content can be determined from neutron logging by calibration to known field soil-moisture contents or, as was done in this study, by using the manufacturer's calibration. Manufacturer's calibration was adequate for this study because the results were used only qualitatively to estimate the rate of vertical wastewater movement. Theory, operation, and calibration of neutron logging are described by Troxler Electronic Laboratories, Inc., (1983).

Weekly monitoring was done at the three new residences (Toltec, Vasquez, and Little Beaver sites) to accurately characterize the initial movement of wastewater. Frequency of monitoring was later
Table 8. Fecal coliform and total bacteria (from standard plate count) for core samples at study sites

[Fecal-coliform and total-bacteria colony counts (colonyforming units) are per gram of wet soil; $\mathrm{ft}$, foot]

\begin{tabular}{|c|c|c|c|}
\hline \multirow{2}{*}{$\begin{array}{l}\text { Sample } \\
\text { depth } \\
\text { (ft) }\end{array}$} & \multirow{2}{*}{ Date } & \multicolumn{2}{|c|}{ Colony count } \\
\hline & & Fecal coliform & Total bacteria \\
\hline \multicolumn{4}{|c|}{ Toltec site (neutron hole) } \\
\hline $5-7$ & $4-7-88$ & 0 & 4,200 \\
\hline $23-24$ & $4-7-88$ & 0 & 0 \\
\hline $32-33$ & $4-8-88$ & 0 & 0 \\
\hline $42-43$ & $4-8-88$ & 0 & 0 \\
\hline $57-58$ & $4-8-88$ & 0 & 0 \\
\hline $77-78$ & $4-8-88$ & 0 & 200 \\
\hline $97-99$ & $4-8-88$ & 0 & 0 \\
\hline \multicolumn{4}{|c|}{ Cheyenne-I site (lysimeter hole) } \\
\hline $12-13$ & $4-9-88$ & 0 & 0 \\
\hline $22-24$ & $4-9-88$ & 0 & 13,000 \\
\hline $27-38$ & $4-10-88$ & 0 & 0 \\
\hline $37-39$ & $4-9-88$ & 0 & 0 \\
\hline $67-69$ & $4-9-88$ & 0 & 250 \\
\hline $77-79$ & $4-10-88$ & 0 & 0 \\
\hline $118-120$ & $4-10-88$ & 0 & ${ }^{1} 120$ \\
\hline 124 & $4-9-88$ & 0 & 560 \\
\hline \multicolumn{4}{|c|}{ Cheyenne-I site (lateral-flow hole) } \\
\hline $27-29$ & $4-11-88$ & 0 & 0 \\
\hline $37-39$ & $4-11-88$ & 0 & 0 \\
\hline $47-49$ & $4-11-88$ & 0 & 0 \\
\hline \multicolumn{4}{|c|}{ Choctaw site (lysimeter hole) } \\
\hline $23-25$ & $4-13-88$ & 0 & 0 \\
\hline $28-30$ & $4-13-88$ & 0 & ${ }^{1} 190$ \\
\hline $43-45$ & $4-13-88$ & 0 & 0 \\
\hline $53-55$ & $4-13-88$ & 0 & 0 \\
\hline $73-75$ & $4-14-88$ & 0 & 0 \\
\hline $113-115$ & $4-14-88$ & 0 & 0 \\
\hline \multicolumn{4}{|c|}{ Kiowa site (lysimeter hole) } \\
\hline $17-19$ & $4-25-88$ & 0 & ${ }^{1} 160$ \\
\hline $22-24$ & $4-25-88$ & 0 & 0 \\
\hline $27-29$ & $4-25-88$ & 0 & 0 \\
\hline $32-34$ & $4-25-88$ & 0 & ${ }^{1} 290$ \\
\hline $37-39$ & $4-26-88$ & 0 & 25,000 \\
\hline $42-44$ & $4-26-88$ & 0 & ${ }^{1} 13,000$ \\
\hline $47-49$ & $4-26-88$ & 0 & 0 \\
\hline $77-79$ & $4-26-88$ & 0 & 0 \\
\hline \multicolumn{4}{|c|}{ Cheyenne-II site (neutron hole) } \\
\hline $12-14$ & $4-27-88$ & 0 & 0 \\
\hline $27-29$ & $4-27-88$ & 0 & 1,200 \\
\hline $32-34$ & $4-27-88$ & 0 & ${ }^{1} 1,800$ \\
\hline $42-44$ & $4-27-88$ & 0 & 0 \\
\hline $67-69$ & $4-27-88$ & 0 & 0 \\
\hline $77-79$ & $4-28-88$ & 0 & 0 \\
\hline $97-99$ & $4-27-88$ & 0 & 0 \\
\hline $117-119$ & $4-28-88$ & 0 & 0 \\
\hline \multicolumn{4}{|c|}{ Cheyenne-II site (lysimeter hole) } \\
\hline $27-29$ & $4-28-88$ & 0 & 0 \\
\hline $43-44$ & $4-28-88$ & 0 & 0 \\
\hline
\end{tabular}

${ }^{\text {I}}$ Estimate based on non-ideal colony count. 
Table 9. Nitrifying and nitrate-reducing bacteria for core samples from Cheyenne-I and Cajon sites

[ft, foot; <, actual value is less than value shown; --, confidence limit cannot be calculated]

\begin{tabular}{|c|c|c|c|c|}
\hline \multirow{2}{*}{$\begin{array}{l}\text { Sample } \\
\text { depth } \\
\text { (ft) }\end{array}$} & \multirow{2}{*}{$\begin{array}{c}\text { Most probable } \\
\text { number (MPN) of } \\
\text { nitrifying bacteria } \\
\text { per gram of wet soil }\end{array}$} & \multirow{2}{*}{$\begin{array}{c}\text { Most probable } \\
\text { number (MPN) of } \\
\text { nitrate-reducing bacteria } \\
\text { per gram of wet soil }\end{array}$} & \multicolumn{2}{|c|}{ 95-percent confidence limits } \\
\hline & & & Lower & Upper \\
\hline \multicolumn{5}{|c|}{$\begin{array}{c}\text { Cheyenne-I site } \\
\text { Samples collected December 6-7, } 1988\end{array}$} \\
\hline 19 & 0 & 4,300 & 700 & 21,000 \\
\hline 24 & 0 & 200 & 70 & 890 \\
\hline 29 & 0 & 23,000 & 4,000 & 120,000 \\
\hline 39 & 0 & 4,300 & 700 & 21,000 \\
\hline 49 & 0 & 150 & 30 & 440 \\
\hline 53 & 0 & 90 & 10 & 360 \\
\hline 64 & 0 & 90 & 10 & 360 \\
\hline 69 & 0 & 40 & $<5$ & 200 \\
\hline 74 & 0 & 140 & 30 & 370 \\
\hline 79 & 0 & 2,300 & 400 & 12,000 \\
\hline 89 & 0 & 30 & $<5$ & 90 \\
\hline 94 & 0 & $<30$ & -- & -- \\
\hline 99 & 0 & 90 & 10 & 360 \\
\hline 109 & 0 & $<30$ & -- & -- \\
\hline \multicolumn{5}{|c|}{$\begin{array}{c}\text { Cajon site } \\
\text { Samples collected November 29-December 2, } 1988\end{array}$} \\
\hline 84 & 0 & 93,000 & 15,000 & 380,000 \\
\hline 123 & 0 & 930 & 150 & 3,800 \\
\hline 182 & 0 & 230 & 40 & 1,200 \\
\hline 242 & 0 & $<30$ & -- & -- \\
\hline
\end{tabular}

reduced to monthly, as was done at the established 2year-old site at Cheyenne-II. The profiles of soilmoisture content over time are presented (in figure 12) later in this report.

\section{PORE-WATER QUALITY}

Time-series water-quality data from the unsaturated zone beneath the seepage pits at all eight residential sites were acquired by frequent sampling of suction lysimeters. Suction lysimeters were sampled by applying a vacuum (about 60 centibars, equal to 40 centibars absolute pressure) greater than soil suction to the interior of a buried porous cup, which induces water to flow from the unsaturated material into the lysimeter. The sampled soil water, which is presumed to have been effectively filtered by its passage through the silica flour and ceramic cup, then was forced to land surface by applying nitrogen gas pressure to one tube of the two-tube system (fig. 10C). Although sampling characteristics varied considerably from one lysimeter to another, about 2 to 4 weeks between the evacuation and subsequent application of nitrogen pressure was found to be necessary for maximum accumulation of water within most lysimeter cups. Shorter periods resulted in incomplete recovery and longer periods apparently result in partial loss of the sample through leakage back into the soil.

Following installation, the lysimeters initially were sampled several times (although few of these samples were analyzed) to establish hydraulic contact between the soil moisture and ceramic cup, to remove contaminants associated with the installation process, and to observe the wastewater plume's rapid initial movement through the unsaturated zone. Monitoring was reduced to once a month or less frequently, at both new and established residences, after this short initial period. Determination of specific conductance and $\mathrm{pH}$ was done in the field immediately after sample collection. Aliquots were sent in polyethylene bottles to the USGS National Water Quality Laboratory in Arvada, Colorado, for analysis of $\mathrm{NO}_{3}$, $\mathrm{NH}_{3}, \mathrm{Cl}, \mathrm{B}$, and alkalinity (and other constituents in a few samples). Bottles for analysis of nutrients (nitrogen species) were chilled, and mercuric chloride was added as a biocide. Water-quality data from the suction lysimeters are presented in table 10. 
Table 10. Chemical analyses of samples from suction lysimeters

[USGS Site Identification No. is explained in headnote for table 4. $\mathrm{ft}$, foot; $\mathrm{mg} / \mathrm{L}$, milligram per liter; $\mu \mathrm{S} / \mathrm{cm}$, microsiemen per centimeter at 25 degrees Celsius; ${ }^{\circ} \mathrm{C}$, degree Celsius; <, less than indicated reporting limit; --, no data]

\begin{tabular}{|c|c|c|c|c|c|c|c|c|c|}
\hline $\begin{array}{l}\text { USGS site } \\
\text { identification } \\
\text { No. } \\
\text { (lysimeter } \\
\text { depth) }\end{array}$ & Date & $\begin{array}{l}\text { Temper- } \\
\text { ature, } \\
\text { water } \\
\left({ }^{\circ} \mathrm{C}\right)\end{array}$ & $\begin{array}{l}\text { Specific } \\
\text { conduct- } \\
\text { ance } \\
(\mu \mathrm{S} / \mathrm{cm})\end{array}$ & $\begin{array}{l}\text { Nitro- } \\
\text { gen } \\
(\mathrm{mg} / \mathrm{L} \\
\text { as } \mathrm{N})\end{array}$ & $\begin{array}{l}\text { Nitro- } \\
\text { gen, } \\
\text { organic } \\
\text { (mg/L } \\
\text { as N) }\end{array}$ & $\begin{array}{c}\text { Nitro- } \\
\text { gen, } \\
\text { ammonia } \\
(\mathrm{mg} / \mathrm{L} \\
\text { as } \mathrm{N})\end{array}$ & $\begin{array}{c}\text { Nitro- } \\
\text { gen, } \\
\mathrm{NO}_{2}+\mathrm{NO}_{3} \\
(\mathrm{mg} / \mathrm{L} \\
\text { as N) }\end{array}$ & $\begin{array}{c}\text { Carbon, } \\
\text { organic } \\
\text { total } \\
(\mathrm{mg} / \mathrm{L} \\
\text { as } \mathrm{C})\end{array}$ & $\begin{array}{l}\text { Calcium } \\
(\mathrm{mg} / \mathrm{L})\end{array}$ \\
\hline \multicolumn{10}{|c|}{ Toltec site } \\
\hline $\begin{array}{l}342655117111401 \\
\quad(73 \mathrm{ft})\end{array}$ & $\begin{array}{r}8-23-89 \\
12-09-89\end{array}$ & $\begin{array}{l}21.5 \\
23.0\end{array}$ & $\begin{array}{l}735 \\
685\end{array}$ & $\begin{array}{l}15 \\
14\end{array}$ & $\begin{array}{l}1.2 \\
.77\end{array}$ & $\begin{array}{r}0.04 \\
.03\end{array}$ & $\begin{array}{l}14 \\
13\end{array}$ & $\begin{array}{l}-- \\
--\end{array}$ & $\begin{array}{l}54 \\
--\end{array}$ \\
\hline $\begin{array}{l}342655117111402 \\
\quad(50 \mathrm{ft})\end{array}$ & $\begin{array}{r}9-12-88 \\
10-14-88 \\
3-06-89 \\
4-10-89 \\
5-22-89 \\
8-23-89 \\
12-09-89\end{array}$ & $\begin{array}{l}26.0 \\
26.0 \\
21.0 \\
20.0 \\
20.0 \\
22.0 \\
23.0\end{array}$ & $\begin{array}{l}740 \\
690 \\
700 \\
820 \\
850 \\
770 \\
770\end{array}$ & $\begin{array}{l}3.0 \\
-- \\
18 \\
22 \\
27 \\
18 \\
18\end{array}$ & $\begin{array}{l}.29 \\
-- \\
1.4 \\
1.7 \\
2.6 \\
.68 \\
--\end{array}$ & $\begin{array}{r}.01 \\
.07 \\
.06 \\
.04 \\
.01 \\
.02 \\
<.01\end{array}$ & $\begin{array}{l}2.7 \\
7.3 \\
17 \\
20 \\
24 \\
17 \\
17\end{array}$ & $\begin{array}{l}-- \\
-- \\
-- \\
-- \\
-- \\
-- \\
--\end{array}$ & $\begin{array}{l}-- \\
-- \\
-- \\
-- \\
-- \\
-- \\
--\end{array}$ \\
\hline $\begin{array}{l}342655117111403 \\
\quad(40 \mathrm{ft})\end{array}$ & $\begin{array}{r}6-02-88 \\
6-08-88 \\
6-09-88 \\
7-13-88 \\
8-09-88 \\
9-12-88 \\
10-14-88 \\
2-06-89 \\
3-06-89 \\
4-10-89 \\
5-22-89 \\
7-08-89 \\
8-23-89 \\
12-09-89\end{array}$ & $\begin{array}{l}-- \\
-- \\
-- \\
24.0 \\
28.0 \\
26.5 \\
26.0 \\
11.0 \\
24.0 \\
20.0 \\
20.0 \\
\ddot{22.0} \\
23.0\end{array}$ & $\begin{array}{r}-- \\
-- \\
-- \\
650 \\
670 \\
730 \\
635 \\
715 \\
810 \\
750 \\
810 \\
-- \\
660 \\
690\end{array}$ & $\begin{array}{c}1.9 \\
4.2 \\
8.3 \\
6.8 \\
-- \\
3.0 \\
-- \\
11 \\
20 \\
7.3 \\
27 \\
22 \\
19 \\
16\end{array}$ & $\begin{array}{l}.38 \\
.82 \\
.56 \\
-- \\
-. \\
.56 \\
-- \\
1.3 \\
1.0 \\
1.8 \\
1.9 \\
1.6 \\
.87 \\
.79\end{array}$ & $\begin{array}{r}.02 \\
.08 \\
.04 \\
<.01 \\
.03 \\
.04 \\
.02 \\
.04 \\
.10 \\
.07 \\
.02 \\
.03 \\
.03 \\
.01\end{array}$ & $\begin{array}{c}1.5 \\
3.3 \\
7.7 \\
6.4 \\
4.8 \\
2.4 \\
8.3 \\
9.9 \\
19 \\
5.4 \\
25 \\
20 \\
18 \\
15\end{array}$ & $\begin{array}{l}-- \\
-- \\
-- \\
-- \\
-- \\
-- \\
- \\
-- \\
-- \\
- \\
- \\
-- \\
- \\
-\end{array}$ & $\begin{array}{c}25 \\
28 \\
-- \\
41 \\
45 \\
55 \\
-- \\
-- \\
- \\
-- \\
-- \\
-- \\
- \\
-\end{array}$ \\
\hline $\begin{array}{l}342655117111404 \\
\quad(33 \mathrm{ft})\end{array}$ & $\begin{array}{r}6-02-88 \\
6-08-88 \\
6-09-88 \\
7-13-88 \\
8-09-88 \\
9-12-88 \\
10-14-88 \\
2-06-89 \\
3-06-89 \\
4-10-89 \\
5-22-89 \\
7-08-89 \\
8-23-89 \\
12-09-89\end{array}$ & $\begin{array}{l}-- \\
-- \\
-- \\
24.0 \\
28.0 \\
26.0 \\
26.0 \\
14.0 \\
25.0 \\
20.5 \\
21.0 \\
-- \\
25.0 \\
23.0\end{array}$ & $\begin{array}{r}-- \\
-- \\
-- \\
490 \\
620 \\
700 \\
615 \\
685 \\
710 \\
740 \\
750 \\
-- \\
610 \\
995\end{array}$ & $\begin{array}{c}2.8 \\
7.2 \\
7.5 \\
7.3 \\
-- \\
-- \\
-- \\
9.5 \\
24 \\
30 \\
22 \\
-- \\
29 \\
--\end{array}$ & $\begin{array}{c}.57 \\
1.2 \\
-- \\
.80 \\
1.0 \\
12 \\
-- \\
1.1 \\
21 \\
8.0 \\
<.10 \\
<.10 \\
9.0 \\
51\end{array}$ & $\begin{array}{c}.03 \\
.05 \\
<.01 \\
3.9 \\
11 \\
1.5 \\
22 \\
7.8 \\
1.6 \\
22 \\
22 \\
23 \\
20 \\
1.6\end{array}$ & $\begin{array}{l}2.2 \\
5.9 \\
6.5 \\
2.6 \\
<.10 \\
<.10 \\
.10 \\
.57 \\
.53 \\
.26 \\
.30 \\
<.10 \\
.17 \\
<.10\end{array}$ & $\begin{array}{l}-- \\
-- \\
-- \\
-- \\
- \\
-- \\
-- \\
- \\
- \\
- \\
- \\
- \\
- \\
- \\
--\end{array}$ & $\begin{array}{c}24 \\
32 \\
-- \\
41 \\
35 \\
40 \\
-- \\
29 \\
-- \\
-- \\
28 \\
-- \\
31 \\
42\end{array}$ \\
\hline \multicolumn{10}{|c|}{ Cheyenne-I site } \\
\hline $\begin{array}{c}343125117121501 \\
\text { (hole } 1,113 \mathrm{ft} \text { ) }\end{array}$ & $\begin{array}{l}5-13-88 \\
6-02-88 \\
6-08-88 \\
7-13-88\end{array}$ & $\begin{array}{l}-- \\
-- \\
-- \\
25.0\end{array}$ & $\begin{array}{r}-- \\
-- \\
-- \\
3,100\end{array}$ & $\begin{array}{l}-- \\
0.50 \\
-- \\
--\end{array}$ & $\begin{array}{r}-. \\
0.35 \\
.40 \\
.42\end{array}$ & $\begin{array}{r}0.02 \\
.05 \\
.10 \\
.08\end{array}$ & $\begin{array}{r}0.71 \\
.10 \\
<.10 \\
<.10\end{array}$ & $\begin{array}{l}-- \\
-- \\
-- \\
--\end{array}$ & $\begin{array}{r}200 \\
260 \\
300 \\
--\end{array}$ \\
\hline
\end{tabular}


Table 10. Chemical analyses of samples from suction lysimeters-- Continued

\begin{tabular}{|c|c|c|c|c|c|c|c|c|c|}
\hline $\begin{array}{l}\text { USGS site } \\
\text { identification } \\
\text { No. } \\
\text { (lysimeter } \\
\text { depth) }\end{array}$ & $\begin{array}{l}\text { Magne- } \\
\text { sium } \\
(\mathrm{mg} / \mathrm{L})\end{array}$ & $\begin{array}{l}\text { Sodium } \\
\text { (mg/L) }\end{array}$ & $\begin{array}{l}\text { Potas- } \\
\text { sium } \\
(\mathrm{mg} / \mathrm{L})\end{array}$ & $\begin{array}{l}\text { Chloride } \\
\text { (mg/L) }\end{array}$ & $\begin{array}{c}\text { Sulfate } \\
(\mathrm{mg} / \mathrm{L} \\
\left.\text { as } \mathrm{SO}_{4}\right)\end{array}$ & $\begin{array}{l}\text { Silica } \\
(\mathrm{mg} / \mathrm{L})\end{array}$ & $\begin{array}{l}\text { Boron } \\
(\mu \mathrm{g} / \mathrm{L})\end{array}$ & $\begin{array}{c}{ }^{15} \mathrm{~N} /{ }^{14} \mathrm{~N} \\
\text { stable- } \\
\text { isotope } \\
\text { ratio } \\
\text { (permil) }\end{array}$ & $\begin{array}{c}\text { Alkalinity, } \\
\text { lab } \\
(\mathrm{mg} / \mathrm{L} \text { as } \\
\left.\mathrm{CaCO}_{3}\right)\end{array}$ \\
\hline \multicolumn{10}{|c|}{ Toltec site--Continued } \\
\hline \multirow{2}{*}{$\begin{array}{l}342655117111401 \\
\quad(73 \mathrm{ft})\end{array}$} & 12 & 79 & 2.9 & 54 & 68 & 84 & 100 & -- & 158 \\
\hline & -- & -- & -- & 28 & 50 & 86 & 90 & -- & 199 \\
\hline \multirow{7}{*}{$\begin{array}{l}342655117111402 \\
\quad(50 \mathrm{ft})\end{array}$} & -- & -- & -- & -- & -- & -- & -- & -- & -- \\
\hline & -- & -- & -- & -- & -- & -- & -- & -- & -- \\
\hline & -- & -- & -- & -- & -- & -- & -- & -- & -- \\
\hline & - & - & -- & -- & -- & -- & -- & -- & -- \\
\hline & - & $\cdots$ & -- & -- & -- & -- & -- & -- & -- \\
\hline & -- & -- & -- & 23 & 31 & 100 & 490 & -- & 263 \\
\hline & -- & -- & -- & -- & -- & -- & -- & -- & -- \\
\hline \multirow{14}{*}{$\begin{array}{l}342655117111403 \\
\quad(40 \mathrm{ft})\end{array}$} & 4.2 & 60 & 3.0 & 12 & 45 & 88 & 100 & -- & 162 \\
\hline & 6.1 & 74 & 2.9 & 11 & 63 & 93 & 90 & -- & 173 \\
\hline & -- & -- & -- & 12 & -- & -- & -- & -- & -- \\
\hline & 9.8 & 70 & 4.2 & 16 & 63 & 87 & 80 & -- & 190 \\
\hline & 12 & 64 & 8.0 & 24 & 31 & 79 & 70 & -. & 244 \\
\hline & 15 & 77 & 7.1 & 29 & 27 & 91 & 80 & -- & 289 \\
\hline & -- & -. & -- & 20 & -- & -- & 110 & - & 289 \\
\hline & -- & -- & -- & 20 & 27 & 98 & 300 & -- & 276 \\
\hline & -- & -- & -- & 25 & 21 & 98 & 780 & -- & 273 \\
\hline & -- & -- & -- & 38 & 17 & 97 & 890 & -. & 250 \\
\hline & -- & -- & -- & 23 & 18 & 91 & 610 & -. & 225 \\
\hline & -- & -- & -- & 20 & 14 & 90 & 390 & -- & 218 \\
\hline & -- & -- & -- & 18 & 18 & 92 & 180 & -- & 205 \\
\hline & -- & -- & -- & 24 & 15 & 88 & 190 & -- & 213 \\
\hline \multirow{14}{*}{$\begin{array}{l}342655117111404 \\
\quad(33 \mathrm{ft})\end{array}$} & 5.6 & 43 & 2.9 & 9.6 & 21 & 27 & 70 & -- & 142 \\
\hline & 7.4 & 31 & 4.6 & 9.5 & 25 & 29 & 40 & -- & 136 \\
\hline & -- & -- & -- & -- & -- & -- & -- & -- & -- \\
\hline & 9.0 & 34 & 16 & 17 & 14 & 31 & 50 & -. & 171 \\
\hline & 8.7 & 47 & 33 & 27 & 7.2 & 37 & 50 & -- & 226 \\
\hline & 10 & 52 & 17 & 24 & 5.0 & 40 & 110 & -- & 173 \\
\hline & -- & -. & -- & 20 & - & -- & 180 & -- & 294 \\
\hline & 7.9 & 91 & 13 & 25 & 11 & 38 & 760 & -- & 322 \\
\hline & -- & -- & -- & 43 & 9.0 & 43 & 680 & -- & 345 \\
\hline & -- & -- & -- & 29 & 3.0 & 39 & 220 & -- & 305 \\
\hline & 7.6 & 62 & 12 & 22 & 2.0 & 39 & 80 & -- & 266 \\
\hline & -. & -- & -- & 21 & 3.0 & 38 & 60 & -- & 272 \\
\hline & 8.0 & 57 & 11 & 23 & 2.0 & 38 & 150 & -- & 244 \\
\hline & 10 & 83 & 11 & 34 & 1.0 & 41 & 710 & -- & 126 \\
\hline \multicolumn{10}{|c|}{ Cheyenne-I site--Continued } \\
\hline \multirow{4}{*}{$\begin{array}{r}343125117121501 \\
\text { (hole } 1,113 \mathrm{ft} \text { ) }\end{array}$} & 51 & 270 & 7.9 & 660 & 360 & 33 & 600 & -- & 103 \\
\hline & 60 & 320 & 8.2 & 820 & 370 & 34 & 690 & -- & 97 \\
\hline & 67 & 320 & 8.4 & 820 & 380 & 32 & 780 & -- & 97 \\
\hline & -- & -- & -- & 830 & 380 & 33 & 740 & -- & 100 \\
\hline
\end{tabular}


Table 10. Chemical analyses of samples from suction lysimeters--Continued

\begin{tabular}{|c|c|c|c|c|c|c|c|c|c|}
\hline $\begin{array}{c}\text { USGS site } \\
\text { identification } \\
\text { No. } \\
\text { (lysimeter } \\
\text { depth) }\end{array}$ & Date & $\begin{array}{l}\text { Temper- } \\
\text { ature, } \\
\text { water } \\
\left({ }^{\circ} \mathrm{C}\right)\end{array}$ & $\begin{array}{l}\text { Specific } \\
\text { conduct- } \\
\text { ance } \\
(\mu \mathrm{S} / \mathrm{cm})\end{array}$ & $\begin{array}{l}\text { Nitro- } \\
\text { gen } \\
(\mathrm{mg} / \mathrm{L} \\
\text { as } \mathrm{N})\end{array}$ & $\begin{array}{l}\text { Nitro- } \\
\text { gen, } \\
\text { organic } \\
\text { (mg/L } \\
\text { as N) }\end{array}$ & $\begin{array}{c}\text { Nitro- } \\
\text { gen, } \\
\text { ammonia } \\
\text { (mg/L } \\
\text { as N) }\end{array}$ & $\begin{array}{c}\text { Nitro- } \\
\text { gen, } \\
\mathrm{NO}_{2}+\mathrm{NO}_{3} \\
(\mathrm{mg} / \mathrm{L} \\
\text { as N) }\end{array}$ & $\begin{array}{l}\text { Carbon, } \\
\text { organic } \\
\text { total } \\
(\mathrm{mg} / \mathrm{L} \\
\text { as C) } \\
\end{array}$ & $\begin{array}{c}\text { Calcium } \\
(\mathrm{mg} / \mathrm{L})\end{array}$ \\
\hline \multicolumn{10}{|c|}{ Cheyenne-I site--Continued } \\
\hline \multirow{9}{*}{$\begin{array}{l}343125117121501 \\
\text { (hole } 1,113 \mathrm{ft})-- \\
\text { Continued }\end{array}$} & 8-09-88 & 25.0 & 3,100 & 0.42 & 0.22 & 0.08 & 0.12 & -. & 260 \\
\hline & $9-12-88$ & 30.0 & 3,200 & .75 & .35 & .05 & .35 & -- & -. \\
\hline & $10-14-88$ & 26.0 & 2,800 & -- & -- & .07 & .95 & -. & -- \\
\hline & $1-27-89$ & 26.0 & 2,750 & 1.4 & .54 & .16 & .66 & -- & -- \\
\hline & 3-06-89 & 22.0 & 2,600 & 2.1 & .53 & .07 & 1.5 & -- & -- \\
\hline & $4-10-89$ & 19.0 & 2,300 & 1.9 & .34 & .06 & 1.5 & 3.8 & 160 \\
\hline & $7-08-89$ & -- & -. & 3.9 & 2.7 & .06 & 1.1 & -- & -- \\
\hline & $8-23-89$ & 24.5 & 2,200 & 1.6 & .43 & .07 & 1.1 & -- & 140 \\
\hline & $1-11-90$ & 24.5 & 1,990 & -- & -- & -- & -- & 10 & -- \\
\hline \multirow{6}{*}{$\begin{array}{c}343125117121508 \\
\text { (hole 2, } 106 \mathrm{ft} \text { ) }\end{array}$} & $3-07-89$ & -- & -- & 2.6 & .66 & .84 & 1.1 & -- & -- \\
\hline & $4-10-89$ & 21.0 & 1,160 & 8.5 & 1.6 & .04 & 6.9 & -- & -- \\
\hline & $5-22-89$ & 20.0 & 1,110 & 6.3 & 1.2 & .03 & 5.1 & -- & -- \\
\hline & 7-08-89 & -- & & 7.3 & .57 & .03 & 6.7 & -- & -- \\
\hline & $8-23-89$ & 25.0 & 1,480 & 19 & .57 & .03 & 18 & -- & -. \\
\hline & $12-10-89$ & 25.0 & 1,420 & - & -- & -- & -- & 4.0 & - \\
\hline \multirow{7}{*}{$\begin{array}{c}343125117121502 \\
\text { (hole } 1,92.5 \mathrm{ft} \text { ) }\end{array}$} & $6-02-88$ & -- & -- & 3.7 & 2.0 & .05 & 1.7 & -- & -- \\
\hline & $6-08-88$ & -- & -- & 5.2 & 1.3 & .07 & 3.8 & -- & -- \\
\hline & $8-09-88$ & -- & 2,100 & -- & -- & -- & -- & -- & -- \\
\hline & $9-12-88$ & -- & 2,250 & -. & -- & -- & -- & -- & -- \\
\hline & $10-14-88$ & 26.0 & 2,160 & -- & -- & .10 & 5.8 & -- & -- \\
\hline & $1-27-89$ & 24.0 & 2,030 & -- & -- & $-\cdot$ & -- & -- & -- \\
\hline & $7-20-89$ & -- & 1,740 & -- & -- & .05 & 32 & -- & -- \\
\hline \multirow{7}{*}{$\begin{array}{c}343125117121509 \\
\text { (hole } 2,73 \mathrm{ft} \text { ) }\end{array}$} & $1-27-89$ & 24.0 & 2,210 & 14 & 1.3 & .04 & 13 & -- & -- \\
\hline & $3-07-89$ & 23.0 & 1,900 & 2.5 & .58 & .82 & 1.1 & -- & -- \\
\hline & $4-10-89$ & 21.0 & 2,440 & 32 & .77 & .13 & 31 & -- & -- \\
\hline & $5-22-89$ & 20.0 & 2,300 & 41 & .96 & .14 & 40 & -- & -- \\
\hline & $7-08-89$ & -- & -- & 42 & 1.2 & .07 & 41 & -- & -- \\
\hline & $7-21-89$ & -- & 2,060 & -. & -- & .06 & 35 & -- & -- \\
\hline & $12-10-89$ & 25.0 & 1,640 & -- & -- & -- & -- & 4.1 & -- \\
\hline \multirow{6}{*}{$\begin{array}{c}343125117121510 \\
(\text { hole } 2,63 \mathrm{ft})\end{array}$} & $4-10-89$ & 21.0 & 1,240 & 31 & 1.7 & .05 & 29 & $-\infty$ & -- \\
\hline & $5-22-89$ & 20.0 & 1,260 & 37 & .88 & .02 & 36 & -- & -- \\
\hline & $7-08-89$ & -- & -- & 35 & .77 & .03 & 34 & $-\infty$ & -- \\
\hline & $7-20-89$ & .. & 1,370 & -- & -- & .01 & 31 & -- & -- \\
\hline & $8-23-89$ & 25.0 & 1,250 & 32 & .68 & .02 & 31 & -- & 54 \\
\hline & $12-10-89$ & 25.0 & 1,160 & 33 & 1.2 & .05 & 32 & 2.5 & -- \\
\hline \multirow{4}{*}{$\begin{array}{l}343125117121511 \\
\text { (hole } 2,42 \mathrm{ft} \text { ) }\end{array}$} & $4-10-89$ & 20.0 & 2,500 & 30 & 2.0 & .05 & 28 & -- & -- \\
\hline & $5-22-89$ & 20.0 & 2,400 & 31 & .95 & .05 & 30 & -- & -- \\
\hline & $7-23-89$ & -- & 2,200 & -- & -- & .02 & 38 & -- & -- \\
\hline & $12-10-89$ & 25.0 & 1,860 & -- & -- & -- & -- & 5.4 & -- \\
\hline \multirow{5}{*}{$\begin{array}{c}343125117121503 \\
\text { (hole } 1,37 \mathrm{ft} \text { ) }\end{array}$} & $6-02-88$ & -- & -- & 60 & .94 & .06 & 59 & -- & 140 \\
\hline & $6-08-88$ & -- & -- & 64 & 1.0 & .07 & 63 & -- & 220 \\
\hline & $7-13-88$ & 25.0 & 2,250 & 63 & -- & $<.01$ & 62 & -- & 220 \\
\hline & $8-09-88$ & 25.0 & 2,300 & 58 & 1.2 & .06 & 57 & -. & 210 \\
\hline & $9-12-88$ & 27.0 & 2,320 & 43 & 1.1 & .03 & 42 & -- & 190 \\
\hline
\end{tabular}


Table 10. Chemical analyses of samples from suction lysimeters--Continued

\begin{tabular}{|c|c|c|c|c|c|c|c|c|c|}
\hline $\begin{array}{l}\text { USGS site } \\
\text { identification } \\
\text { No. } \\
\text { (lysimeter } \\
\text { depth) }\end{array}$ & $\begin{array}{l}\text { Magne- } \\
\text { sium } \\
(\mathrm{mg} / \mathrm{L})\end{array}$ & $\begin{array}{l}\text { Sodium } \\
(\mathrm{mg} / \mathrm{L})\end{array}$ & $\begin{array}{l}\text { Potas- } \\
\text { sium } \\
(\mathrm{mg} / \mathrm{L})\end{array}$ & $\begin{array}{l}\text { Chloride } \\
(\mathrm{mg} / \mathrm{L})\end{array}$ & $\begin{array}{l}\text { Sulfate } \\
(\mathrm{mg} / \mathrm{L} \\
\left.\text { as } \mathrm{SO}_{4}\right)\end{array}$ & $\begin{array}{l}\text { Silica } \\
(\mathrm{mg} / \mathrm{L})\end{array}$ & $\begin{array}{l}\text { Boron } \\
(\mu \mathrm{g} / \mathrm{L})\end{array}$ & $\begin{array}{l}{ }^{15} \mathrm{~N} /{ }^{14} \mathrm{~N} \\
\text { stable- } \\
\text { isotope } \\
\text { ratio } \\
\text { (permil) }\end{array}$ & $\begin{array}{l}\text { Alkalinity, } \\
\text { lab } \\
(\mathrm{mg} / \mathrm{L} \text { as } \\
\left.\mathrm{CaCO}_{3}\right)\end{array}$ \\
\hline \multicolumn{10}{|c|}{ Cheyenne-I site--Continued } \\
\hline \multirow{9}{*}{$\begin{array}{l}343125117121501 \\
\text { (hole 1, 113 ft)-- } \\
\text { Continued }\end{array}$} & 62 & 320 & 7.3 & 780 & 370 & 33 & 770 & -- & 92 \\
\hline & -- & -- & -- & 750 & 350 & 32 & 850 & -- & 105 \\
\hline & -- & -- & -- & 690 & -- & -- & 880 & -- & 113 \\
\hline & -- & -- & -- & 670 & 340 & 33 & 800 & -- & 113 \\
\hline & -- & -- & -- & 570 & 320 & 35 & 800 & -- & 121 \\
\hline & 41 & 270 & 6.6 & 110 & 310 & 34 & 830 & -- & 122 \\
\hline & -- & -- & -- & -- & -- & -- & -- & -- & -- \\
\hline & 36 & 240 & 6.4 & 450 & 280 & 33 & 800 & -- & 134 \\
\hline & -- & -- & -- & -- & -- & -- & -- & -- & -- \\
\hline \multirow{6}{*}{$\begin{array}{r}343125117121508 \\
\text { (hole } 2,106 \mathrm{ft})\end{array}$} & -- & -- & -- & -- & -- & -- & -- & -- & -- \\
\hline & -- & -- & -- & -- & -. & -- & -- & -- & -- \\
\hline & -- & -- & -- & 280 & 210 & 31 & 610 & -- & 120 \\
\hline & -- & -- & -- & -- & -. & -- & -- & -- & -- \\
\hline & -- & -- & -- & -- & -- & -- & -- & -- & -- \\
\hline & -- & -- & -- & -- & -- & -- & -- & -- & -- \\
\hline \multirow{7}{*}{$\begin{array}{r}343125117121502 \\
\text { (hole } 1,92.5 \mathrm{ft} \text { ) }\end{array}$} & -- & -- & -. & -- & -- & -- & -- & -- & -- \\
\hline & -- & -- & -- & -- & -- & -- & -- & -- & -- \\
\hline & & -- & -- & -- & -- & -. & -- & -- & ---- \\
\hline & -- & -- & -- & -- & -- & -- & -- & -- & -- \\
\hline & -- & -- & -- & -- & -. & .- & -- & -- & -- \\
\hline & -. & -- & -- & -- & -- & -- & -- & -- & -- \\
\hline & -- & -- & -- & -- & -- & -- & -- & 7.80 & -- \\
\hline \multirow{7}{*}{$\begin{array}{c}343125117121509 \\
\text { (hole } 2,73 \mathrm{ft} \text { ) }\end{array}$} & -- & -- & .- & -- & -- & -- & -- & -. & -- \\
\hline & -- & -- & -- & 370 & 150 & 3.1 & 270 & -- & 23 \\
\hline & -- & -- & -- & 99 & 790 & 24 & 2,600 & -- & 197 \\
\hline & -- & -- & -- & 280 & 430 & 24 & 4,800 & -- & 284 \\
\hline & -- & -- & -- & 200 & 310 & 23 & 5,900 & -- & 255 \\
\hline & -- & -- & -- & -- & -- & -- & - & 8.30 & -- \\
\hline & -- & -- & -- & -- & -- & -- & -- & -- & -- \\
\hline \multirow{6}{*}{$\begin{array}{c}343125117121510 \\
\text { (hole 2, } 63 \mathrm{ft} \text { ) }\end{array}$} & -- & -- & -- & 200 & 73 & 76 & 7,900 & -- & 353 \\
\hline & -- & -- & -- & 160 & 49 & 49 & 7,300 & -- & 315 \\
\hline & -- & -.- & -- & 130 & 43 & 46 & 6,700 & -- & 295 \\
\hline & -- & -- & -- & -- & -- & -- & -- & 8.70 & -- \\
\hline & 15 & 180 & 3.0 & 88 & 54 & 44 & 6,700 & -- & 306 \\
\hline & -- & -- & -- & -- & -- & -- & -- & -- & -- \\
\hline \multirow{4}{*}{$\begin{array}{c}343125117121511 \\
\text { (hole } 2,42 \mathrm{ft} \text { ) }\end{array}$} & -- & -- & -- & 290 & 590 & 94 & 3,900 & -- & 365 \\
\hline & -- & -- & -- & 230 & 430 & 94 & 5,100 & -- & 314 \\
\hline & -- & -- & -- & -- & -- & -- & -- & 7.90 & -- \\
\hline & -- & -- & -- & -- & -- & -- & -- & -- & -- \\
\hline \multirow{5}{*}{$\begin{array}{c}343125117121503 \\
\text { (hole } 1,37 \mathrm{ft})\end{array}$} & 44 & 260 & 10 & 320 & 390 & 92 & 5,300 & -- & 291 \\
\hline & 44 & 230 & 10 & 300 & 420 & 98 & 5,200 & -- & 274 \\
\hline & 45 & 240 & 9.2 & 280 & 410 & 90 & 5,500 & -- & 266 \\
\hline & 42 & 230 & 8.4 & 260 & 410 & 95 & 5,800 & -- & 257 \\
\hline & 37 & 230 & 7.8 & 240 & 390 & 90 & 6,800 & -- & 254 \\
\hline
\end{tabular}


Table 10. Chemical analyses of samples from suction lysimeters--Continued

\begin{tabular}{|c|c|c|c|c|c|c|c|c|c|}
\hline $\begin{array}{c}\text { USGS site } \\
\text { identification } \\
\text { No. } \\
\text { (lysimeter } \\
\text { depth) }\end{array}$ & Date & $\begin{array}{l}\text { Temper- } \\
\text { ature, } \\
\text { water } \\
\left({ }^{\circ} \mathrm{C}\right)\end{array}$ & $\begin{array}{l}\text { Specific } \\
\text { conduct- } \\
\text { ance } \\
(\mu \mathrm{S} / \mathrm{cm})\end{array}$ & $\begin{array}{l}\text { Nitro- } \\
\text { gen } \\
(\mathrm{mg} / \mathrm{L} \\
\text { as } \mathrm{N})\end{array}$ & $\begin{array}{l}\text { Nitro- } \\
\text { gen, } \\
\text { organic } \\
\text { (mg/L } \\
\text { as N) }\end{array}$ & $\begin{array}{c}\text { Nitro- } \\
\text { gen, } \\
\text { ammonia } \\
(\mathrm{mg} / \mathrm{L} \\
\text { as N) }\end{array}$ & $\begin{array}{c}\text { Nitro- } \\
\text { gen, } \\
\mathrm{NO}_{2}+\mathrm{NO}_{3} \\
(\mathrm{mg} / \mathrm{L} \\
\text { as N)} \\
\end{array}$ & $\begin{array}{l}\text { Carbon, } \\
\text { organic } \\
\text { total } \\
(\mathrm{mg} / \mathrm{L} \\
\text { as } \mathrm{C}) \\
\end{array}$ & $\begin{array}{c}\text { Calcium } \\
(\mathrm{mg} / \mathrm{L})\end{array}$ \\
\hline \multicolumn{10}{|c|}{ Cheyenne-I site--Continued } \\
\hline $\begin{array}{c}343125117121503 \\
\text { (hole } 1,37 \mathrm{ft})-- \\
\text { Continued }\end{array}$ & $\begin{array}{r}10-14-88 \\
1-27-89 \\
3-06-89 \\
4-10-89 \\
7-08-89 \\
7-20-89 \\
8-23-89 \\
1-11-90\end{array}$ & $\begin{array}{c}26.0 \\
25.0 \\
22.0 \\
19.5 \\
-- \\
-- \\
25.0 \\
25.0\end{array}$ & $\begin{array}{r}2,110 \\
1,940 \\
2,050 \\
1,660 \\
- \\
1,920 \\
1,650 \\
1,610\end{array}$ & $\begin{array}{r}-- \\
40 \\
52 \\
35 \\
42 \\
-- \\
38 \\
40\end{array}$ & $\begin{array}{c}-. \\
1.7 \\
.75 \\
1.0 \\
.57 \\
-- \\
.68 \\
.68\end{array}$ & $\begin{array}{r}0.06 \\
.02 \\
.05 \\
.06 \\
.03 \\
.03 \\
.02 \\
.02\end{array}$ & $\begin{array}{l}11 \\
38 \\
51 \\
34 \\
41 \\
32 \\
37 \\
39\end{array}$ & $\begin{array}{l}-- \\
-- \\
-- \\
3.1 \\
-- \\
-- \\
-- \\
4.0\end{array}$ & $\begin{array}{r}-- \\
-- \\
-- \\
150 \\
-- \\
-- \\
130 \\
--\end{array}$ \\
\hline \multicolumn{10}{|c|}{ Vasquez site } \\
\hline $\begin{array}{l}343314117195201 \\
\quad(71 \mathrm{ft})\end{array}$ & $\begin{array}{r}6-22-88 \\
7-12-88 \\
8-08-88 \\
9-12-88 \\
10-14-88 \\
2-06-89 \\
3-06-89 \\
4-10-89 \\
5-22-89 \\
1-11-90\end{array}$ & $\begin{array}{r}-\overline{24.5} \\
28.0 \\
- \\
24.0 \\
9.0 \\
21.0 \\
20.0 \\
20.0 \\
23.0\end{array}$ & $\begin{array}{r}700 \\
720 \\
800 \\
-- \\
820 \\
840 \\
850 \\
860 \\
840 \\
950\end{array}$ & $\begin{array}{l}6.4 \\
7.2 \\
6.9 \\
5.3 \\
-- \\
4.3 \\
4.6 \\
4.1 \\
4.1 \\
3.3\end{array}$ & $\begin{array}{l}1.1 \\
-- \\
.67 \\
-- \\
-- \\
.75 \\
.37 \\
.17 \\
.37 \\
.79\end{array}$ & $\begin{array}{r}0.02 \\
<.01 \\
.03 \\
<.01 \\
.04 \\
.05 \\
.03 \\
.03 \\
.03 \\
.31\end{array}$ & $\begin{array}{l}5.3 \\
6.5 \\
6.2 \\
4.4 \\
5.4 \\
3.5 \\
4.2 \\
3.9 \\
3.7 \\
2.2\end{array}$ & $\begin{array}{l}-- \\
-- \\
-- \\
-- \\
-- \\
-- \\
-- \\
-- \\
-- \\
--\end{array}$ & $\begin{array}{l}32 \\
-- \\
-- \\
-- \\
-- \\
-- \\
-- \\
-- \\
--\end{array}$ \\
\hline $\begin{array}{l}343314117195202 \\
\quad(51 \mathrm{ft})\end{array}$ & $\begin{array}{l}6-02-88 \\
6-08-88\end{array}$ & $\begin{array}{c}29.5 \\
--\end{array}$ & $\begin{array}{r}900 \\
--\end{array}$ & $\begin{array}{l}6.4 \\
7.6\end{array}$ & $\begin{array}{l}.39 \\
.78\end{array}$ & $\begin{array}{l}.01 \\
.02\end{array}$ & $\begin{array}{l}6.0 \\
6.8\end{array}$ & $\begin{array}{l}-- \\
--\end{array}$ & $\begin{array}{r}52 \\
--\end{array}$ \\
\hline $\begin{array}{l}343314117195203 \\
\quad(43 \mathrm{ft})\end{array}$ & $\begin{array}{r}5-19-88 \\
6-02-88 \\
6-08-88 \\
7-13-88 \\
8-08-88 \\
9-12-88 \\
10-14-88 \\
2-06-89 \\
3-06-89 \\
4-10-89 \\
5-22-89 \\
8-23-89\end{array}$ & $\begin{array}{c}-\overline{30.0} \\
-\overline{-} \\
25.0 \\
28.0 \\
-\overline{24.0} \\
13.0 \\
21.0 \\
20.0 \\
20.0 \\
22.0\end{array}$ & $\begin{array}{r}-- \\
1,850 \\
-- \\
930 \\
1,600 \\
1,300 \\
1,220 \\
860 \\
1,100 \\
940 \\
960 \\
850\end{array}$ & $\begin{array}{l}6.7 \\
-- \\
-- \\
-- \\
-- \\
-- \\
-- \\
-- \\
4.0 \\
-- \\
-- \\
--\end{array}$ & $\begin{array}{l}-- \\
-- \\
-- \\
-- \\
.76 \\
-- \\
-- \\
.50 \\
.40 \\
1.5 \\
.40 \\
<.10\end{array}$ & $\begin{array}{l}<.01 \\
-- \\
-- \\
<.01 \\
.04 \\
<.01 \\
.27 \\
2.8 \\
3.2 \\
3.6 \\
5.2 \\
7.7\end{array}$ & $\begin{array}{l}6.2 \\
- \\
- \\
<.10 \\
<.10 \\
<.10 \\
<.10 \\
<.10 \\
.35 \\
<.10 \\
<.10 \\
<.10\end{array}$ & $\begin{array}{l}-- \\
-- \\
-- \\
-- \\
-- \\
-- \\
-- \\
-- \\
-- \\
-- \\
-- \\
--\end{array}$ & $\begin{array}{l}59 \\
20 \\
12 \\
11 \\
17 \\
17 \\
-- \\
-- \\
-- \\
20 \\
-- \\
16\end{array}$ \\
\hline $\begin{array}{l}343314117195204 \\
\quad(35 \mathrm{ft})\end{array}$ & $\begin{array}{r}5-19-88 \\
6-02-88 \\
6-08-88 \\
7-13-88 \\
8-08-88 \\
9-12-88 \\
10-14-88 \\
2-06-89 \\
3-06-89 \\
4-10-89 \\
8-23-89\end{array}$ & $\begin{array}{c}-- \\
29.0 \\
-- \\
25.0 \\
28.0 \\
27.0 \\
24.0 \\
12.0 \\
21.0 \\
20.0 \\
22.0\end{array}$ & $\begin{array}{r}-- \\
1,550 \\
-- \\
1,550 \\
1,550 \\
1,240 \\
1,120 \\
805 \\
1,150 \\
870 \\
890\end{array}$ & $\begin{array}{l}-- \\
6.3 \\
6.5 \\
5.9 \\
5.7 \\
6.1 \\
-- \\
1.5 \\
1.8 \\
2.8 \\
11\end{array}$ & $\begin{array}{l}-- \\
.49 \\
.67 \\
-- \\
-- \\
-- \\
-- \\
1.2 \\
.77 \\
.77 \\
1.1\end{array}$ & $\begin{array}{r}<.01 \\
.01 \\
.03 \\
<.01 \\
<.01 \\
<.01 \\
.03 \\
.07 \\
.03 \\
.03 \\
.03\end{array}$ & $\begin{array}{c}11 \\
5.8 \\
5.8 \\
4.9 \\
4.7 \\
5.1 \\
5.0 \\
.17 \\
1.0 \\
2.0 \\
10\end{array}$ & $\begin{array}{l}-- \\
-- \\
-- \\
-- \\
-- \\
-- \\
-- \\
-- \\
-- \\
-- \\
--\end{array}$ & $\begin{array}{r}25 \\
48 \\
44 \\
51 \\
39 \\
40 \\
-- \\
-- \\
-- \\
-- \\
64\end{array}$ \\
\hline
\end{tabular}


Table 10. Chemical analyses of samples from suction lysimeters--Continued

\begin{tabular}{|c|c|c|c|c|c|c|c|c|c|}
\hline $\begin{array}{l}\text { USGS site } \\
\text { identification } \\
\text { No. } \\
\text { (lysimeter } \\
\text { depth) }\end{array}$ & $\begin{array}{l}\text { Magne- } \\
\text { sium } \\
(\mathrm{mg} / \mathrm{L})\end{array}$ & $\begin{array}{l}\text { Sodium } \\
(\mathrm{mg} / \mathrm{L})\end{array}$ & $\begin{array}{l}\text { Potas- } \\
\text { sium } \\
(\mathrm{mg} / \mathrm{L})\end{array}$ & $\begin{array}{l}\text { Chloride } \\
\text { (mg/L) }\end{array}$ & $\begin{array}{l}\text { Sulfate } \\
(\mathrm{mg} / \mathrm{L} \\
\left.\text { as } \mathrm{SO}_{4}\right)\end{array}$ & $\begin{array}{l}\text { Silica } \\
(\mathrm{mg} / \mathrm{L})\end{array}$ & $\begin{array}{l}\text { Boron } \\
(\mu \mathrm{g} / \mathrm{L})\end{array}$ & $\begin{array}{l}{ }^{15} \mathrm{~N} /{ }^{14} \mathrm{~N} \\
\text { stable- } \\
\text { isotope } \\
\text { ratio } \\
\text { (permil) }\end{array}$ & $\begin{array}{c}\text { Alkalinity, } \\
\text { lab } \\
(\mathrm{mg} / \mathrm{L} \text { as } \\
\left.\mathrm{CaCO}_{3}\right)\end{array}$ \\
\hline \multicolumn{10}{|c|}{ Cheyenne-I site--Continued } \\
\hline 343125117121503 & -- & -- & -- & 230 & -- & -- & 7,100 & -- & 258 \\
\hline (hole 1, $37 \mathrm{ft}$ )-- & -- & -- & -- & 210 & 360 & 98 & 6,500 & -- & 253 \\
\hline \multirow{6}{*}{ Continued } & -- & -- & -- & 210 & 330 & 100 & 6,500 & .. & 255 \\
\hline & 32 & 200 & 5.9 & 200 & 300 & 95 & 6,700 & -- & 259 \\
\hline & -- & -- & -- & 170 & 230 & 97 & 6,600 & -- & 291 \\
\hline & -- & -- & -- & -- & -- & -- & -- & 8.70 & -- \\
\hline & 25 & 200 & 5.6 & 150 & 190 & 96 & 6,000 & -- & 328 \\
\hline & -- & -- & -- & 130 & 160 & 96 & 6,200 & -- & 325 \\
\hline \multicolumn{10}{|c|}{ Vasquez site--Continued } \\
\hline \multirow{10}{*}{$\begin{array}{l}343314117195201 \\
\quad(71 \mathrm{ft})\end{array}$} & -- & -- & -- & -- & -- & -- & -- & -- & -- \\
\hline & 12 & 100 & 5.6 & 37 & 37 & 97 & 170 & -- & 265 \\
\hline & -- & -- & -- & 33 & 55 & 25 & 170 & -- & 263 \\
\hline & -- & -- & -- & -- & -- & -- & -- & -- & -- \\
\hline & -- & -- & -- & -- & -- & -- & -- & -. & -- \\
\hline & -- & -- & -- & -- & -- & -- & -- & .. & -- \\
\hline & -- & -- & -- & 30 & 280 & 110 & 120 & -- & 146 \\
\hline & -- & -- & -. & 28 & 290 & 110 & 120 & -- & 139 \\
\hline & -- & -- & -- & 25 & 270 & 100 & 130 & -- & 125 \\
\hline & -- & -- & -- & -- & - & -- & -- & -- & -- \\
\hline \multirow{2}{*}{$\begin{array}{l}343314117195202 \\
\quad(51 \mathrm{ft})\end{array}$} & 15 & 77 & 3.1 & 36 & 49 & 93 & 150 & -- & 250 \\
\hline & -- & -- & -- & 35 & 40 & 100 & 140 & -- & 261 \\
\hline \multirow{12}{*}{$\begin{array}{l}343314117195203 \\
\quad(43 \mathrm{ft})\end{array}$} & 15 & 74 & 3.5 & 46 & 70 & 95 & 180 & -- & 225 \\
\hline & 5.6 & 350 & 4.9 & 67 & 400 & 21 & 190 & -- & 326 \\
\hline & 3.3 & 240 & 3.8 & 45 & 170 & 22 & 150 & -- & 343 \\
\hline & 3.1 & 210 & 3.3 & 41 & 100 & 25 & 130 & -- & 352 \\
\hline & 4.7 & 300 & 4.3 & 44 & 260 & 23 & 180 & -- & 409 \\
\hline & 5.0 & 270 & 3.3 & 38 & 190 & 22 & 190 & -- & 420 \\
\hline & -- & -- & -- & 30 & -- & -- & 190 & -- & 409 \\
\hline & -- & .- & .. & 27 & 130 & 22 & 150 & -- & 412 \\
\hline & -- & -- & -- & 26 & 72 & 25 & 130 & -- & 430 \\
\hline & 5.6 & 190 & 5.6 & 26 & 48 & 24 & 120 & -- & 457 \\
\hline & -- & -- & -- & 24 & 41 & 25 & 110 & -- & 437 \\
\hline & 4.6 & 160 & 6.7 & 26 & 20 & 26 & 120 & -- & 382 \\
\hline \multirow{11}{*}{$\begin{array}{l}343314117195204 \\
\quad(35 \mathrm{ft})\end{array}$} & 6.4 & 400 & 5.5 & 83 & 540 & 23 & 190 & -- & 259 \\
\hline & 14 & 240 & 7.0 & 160 & 170 & 100 & 350 & -- & 268 \\
\hline & 14 & 250 & 7.8 & 180 & 180 & 100 & 380 & -- & 293 \\
\hline & 17 & 260 & 8.0 & 200 & 210 & 99 & 420 & -.- & 294 \\
\hline & 15 & 230 & 7.9 & 130 & 170 & 100 & 420 & -- & 351 \\
\hline & 16 & 210 & 7.4 & 71 & 130 & 100 & 400 & -- & 386 \\
\hline & -. & -. & -- & 41 & -. & -- & 340 & -. & 411 \\
\hline & .. & -- & -- & 26 & 63 & 110 & 220 & -. & 424 \\
\hline & -- & .- & .. & 26 & 45 & 110 & 160 & -- & 428 \\
\hline & -- & -- & -- & 25 & 32 & 110 & 150 & -- & 443 \\
\hline & 15 & 140 & 4.3 & 25 & 18 & 110 & 140 & .- & 415 \\
\hline
\end{tabular}


Table 10. Chemical analyses of samples from suction lysimeters--Continued

\begin{tabular}{|c|c|c|c|c|c|c|c|c|c|}
\hline $\begin{array}{c}\text { USGS site } \\
\text { identification } \\
\text { No. } \\
\text { (lysimeter } \\
\text { depth) }\end{array}$ & Date & $\begin{array}{l}\text { Temper- } \\
\text { ature, } \\
\text { water } \\
\left({ }^{\circ} \mathrm{C}\right)\end{array}$ & $\begin{array}{l}\text { Specific } \\
\text { conduct- } \\
\text { ance } \\
(\mu \mathrm{S} / \mathrm{cm})\end{array}$ & $\begin{array}{l}\text { Nitro- } \\
\text { gen } \\
(\mathrm{mg} / \mathrm{L} \\
\text { as } \mathrm{N})\end{array}$ & $\begin{array}{l}\text { Nitro- } \\
\text { gen, } \\
\text { organic } \\
\text { (mg/L } \\
\text { as } \mathrm{N}) \\
\end{array}$ & $\begin{array}{c}\text { Nitro- } \\
\text { gen, } \\
\text { ammonia } \\
(\mathrm{mg} / \mathrm{L} \\
\text { as N) }\end{array}$ & $\begin{array}{c}\text { Nitro- } \\
\text { gen, } \\
\mathrm{NO}_{2}+\mathrm{NO}_{3} \\
(\mathrm{mg} / \mathrm{L} \\
\text { as N) }\end{array}$ & $\begin{array}{c}\text { Carbon, } \\
\text { organic } \\
\text { total } \\
(\mathrm{mg} / \mathrm{L} \\
\text { as } \mathrm{C}) \\
\end{array}$ & $\begin{array}{c}\text { Calcium } \\
(\mathrm{mg} / \mathrm{L})\end{array}$ \\
\hline \multicolumn{10}{|c|}{ Choctaw site } \\
\hline $\begin{array}{l}343124117143001 \\
(131 \mathrm{ft}) \\
\text { [within } \\
\text { saturated } \\
\text { zone] }\end{array}$ & $\begin{array}{r}6-02-88 \\
6-08-88 \\
7-13-88 \\
8-08-88 \\
9-13-88 \\
10-14-88 \\
1-27-89 \\
3-06-89 \\
4-10-89 \\
7-08-89 \\
8-23-89 \\
1-11-90\end{array}$ & $\begin{array}{c}-- \\
-\overline{24.0} \\
-- \\
27.0 \\
26.0 \\
20.0 \\
22.0 \\
21.0 \\
-\overline{22.0} \\
24.0\end{array}$ & $\begin{array}{r}-- \\
-- \\
1,120 \\
1,400 \\
1,150 \\
1,130 \\
1,170 \\
1,160 \\
1,050 \\
-\overline{1} \\
1,050 \\
1,040\end{array}$ & $\begin{array}{c}1.1 \\
1.5 \\
1.3 \\
1.2 \\
.88 \\
-- \\
.88 \\
.89 \\
1.0 \\
.79 \\
1.2 \\
.52\end{array}$ & $\begin{array}{c}0.58 \\
.47 \\
-- \\
.48 \\
-- \\
-- \\
.36 \\
.28 \\
.26 \\
.27 \\
.48 \\
.39\end{array}$ & $\begin{array}{r}0.02 \\
.03 \\
<.01 \\
.02 \\
<.01 \\
.02 \\
.04 \\
.02 \\
.04 \\
.03 \\
.02 \\
.01\end{array}$ & $\begin{array}{l}0.47 \\
1.0 \\
.89 \\
.67 \\
.58 \\
.73 \\
.48 \\
.59 \\
.70 \\
.49 \\
.73 \\
.12\end{array}$ & $\begin{array}{l}-- \\
-- \\
-- \\
- \\
- \\
-- \\
- \\
- \\
- \\
- \\
--\end{array}$ & $\begin{array}{l}90 \\
75 \\
92 \\
89 \\
91 \\
-- \\
-- \\
-- \\
94 \\
89 \\
91 \\
--\end{array}$ \\
\hline $\begin{array}{l}343124117143002 \\
\quad(80 \mathrm{ft})\end{array}$ & $\begin{array}{r}6-02-88 \\
6-08-88 \\
7-13-88 \\
8-08-88 \\
9-13-88 \\
10-14-88 \\
1-27-89 \\
3-06-89 \\
4-10-89 \\
7-08-89 \\
8-23-89 \\
1-11-90\end{array}$ & $\begin{array}{l}-- \\
\overline{25.0} \\
-- \\
27.0 \\
26.0 \\
20.0 \\
22.0 \\
21.0 \\
\overline{-} \\
22.5 \\
24.0\end{array}$ & $\begin{array}{r}-- \\
-- \\
1,100 \\
1,160 \\
990 \\
920 \\
970 \\
1,100 \\
950 \\
-- \\
1,100 \\
1,010\end{array}$ & $\begin{array}{c}-- \\
-\overline{1} \\
19 \\
-- \\
14 \\
- \\
14 \\
22 \\
24 \\
24 \\
25 \\
26\end{array}$ & $\begin{array}{l}-- \\
-- \\
-- \\
-- \\
-- \\
- \\
1.7 \\
1.2 \\
1.3 \\
2.0 \\
.53 \\
1.4\end{array}$ & $\begin{array}{l}-- \\
-- \\
<.01 \\
-- \\
<.01 \\
.04 \\
.31 \\
.02 \\
.04 \\
.05 \\
.07 \\
.06\end{array}$ & $\begin{array}{c}-- \\
- \\
17 \\
-- \\
13 \\
20 \\
12 \\
21 \\
23 \\
22 \\
24 \\
24\end{array}$ & $\begin{array}{l}-- \\
-- \\
-- \\
- \\
- \\
-- \\
-- \\
- \\
-- \\
- \\
- \\
--\end{array}$ & $\begin{array}{l}-- \\
-- \\
-- \\
- \\
- \\
-- \\
-- \\
- \\
-- \\
- \\
- \\
--\end{array}$ \\
\hline $\begin{array}{l}343124117143003 \\
\quad(48 \mathrm{ft})\end{array}$ & $\begin{array}{r}5-19-88 \\
6-08-88 \\
8-08-88 \\
9-13-88 \\
10-14-88\end{array}$ & $\begin{array}{l}-- \\
-- \\
\overline{27.0} \\
26.0\end{array}$ & $\begin{array}{r}-- \\
\overline{-} \\
1,750 \\
1,560 \\
1,460\end{array}$ & $\begin{array}{l}-- \\
11 \\
15 \\
9.8 \\
--\end{array}$ & $\begin{array}{l}- \\
1.2 \\
1.5 \\
-- \\
--\end{array}$ & $\begin{array}{r}<.01 \\
.05 \\
.01 \\
<.01 \\
.05\end{array}$ & $\begin{array}{c}18 \\
10 \\
13 \\
8.8 \\
14\end{array}$ & $\begin{array}{l}-- \\
-- \\
-- \\
- \\
--\end{array}$ & $\begin{array}{l}86 \\
-- \\
-- \\
-- \\
--\end{array}$ \\
\hline $\begin{array}{l}343124117143004 \\
(33 \mathrm{ft})\end{array}$ & $\begin{array}{r}5-19-88 \\
6-02-88 \\
6-08-88 \\
7-13-88 \\
8-08-88 \\
9-13-88 \\
10-14-88 \\
1-27-89\end{array}$ & $\begin{array}{l}-- \\
-- \\
-- \\
25.0 \\
-- \\
-- \\
26.0 \\
17.0\end{array}$ & $\begin{array}{r}-- \\
-- \\
-- \\
1,620 \\
1,750 \\
-- \\
1,380 \\
1,480\end{array}$ & $\begin{array}{c}8.9 \\
7.1 \\
7.2 \\
6.4 \\
6.2 \\
-- \\
-- \\
12\end{array}$ & $\begin{array}{l}1.0 \\
.62 \\
.93 \\
-- \\
.44 \\
-- \\
-- \\
.78\end{array}$ & $\begin{array}{r}.05 \\
.08 \\
.07 \\
<.01 \\
.06 \\
-.0 \\
.03 \\
.02\end{array}$ & $\begin{array}{c}7.8 \\
6.4 \\
6.2 \\
5.6 \\
5.7 \\
-- \\
8.3 \\
11\end{array}$ & $\begin{array}{l}-- \\
-- \\
-- \\
-- \\
-- \\
- \\
- \\
--\end{array}$ & $\begin{array}{r}-- \\
160 \\
160 \\
130 \\
130 \\
130 \\
-- \\
--\end{array}$ \\
\hline $\begin{array}{c}343124117143005 \\
\text { (lateral-flow } \\
\text { hole, } 48 \mathrm{ft} \text { ) }\end{array}$ & $5-19-88$ & -- & -- & 7.7 & 1.1 & .04 & 6.6 & -- & 200 \\
\hline
\end{tabular}


Table 10. Chemical analyses of samples from suction lysimeters--Continued

\begin{tabular}{|c|c|c|c|c|c|c|c|c|c|}
\hline $\begin{array}{c}\text { USGS site } \\
\text { identification } \\
\text { No. } \\
\text { (lysimeter } \\
\text { depth) }\end{array}$ & $\begin{array}{l}\text { Magne- } \\
\text { sium } \\
(\mathrm{mg} / \mathrm{L})\end{array}$ & $\begin{array}{l}\text { Sodium } \\
(\mathrm{mg} / \mathrm{L})\end{array}$ & $\begin{array}{l}\text { Potas- } \\
\text { sium } \\
(\mathrm{mg} / \mathrm{L})\end{array}$ & $\begin{array}{l}\text { Chloride } \\
\text { (mg/L) }\end{array}$ & $\begin{array}{c}\text { Sulfate } \\
(\mathrm{mg} / \mathrm{L} \\
\left.\text { as } \mathrm{SO}_{4}\right)\end{array}$ & $\begin{array}{l}\text { Silica } \\
(\mathrm{mg} / \mathrm{L})\end{array}$ & $\begin{array}{l}\text { Boron } \\
(\mu \mathrm{g} / \mathrm{L})\end{array}$ & $\begin{array}{c}{ }^{15} \mathrm{~N} /{ }^{14} \mathrm{~N} \\
\text { stable- } \\
\text { isotope } \\
\text { ratio } \\
\text { (permil) }\end{array}$ & $\begin{array}{c}\text { Alkalinity, } \\
\text { lab } \\
(\mathrm{mg} / \mathrm{L} \text { as } \\
\mathrm{CaCO}_{3} \text { ) }\end{array}$ \\
\hline \multicolumn{10}{|c|}{ Choctaw site--Continued } \\
\hline $\begin{array}{l}343123117143001 \\
(131 \mathrm{ft}) \\
\text { [within } \\
\text { saturated } \\
\text { zone] }\end{array}$ & $\begin{array}{r}20 \\
20 \\
20 \\
20 \\
21 \\
-- \\
-- \\
-- \\
21 \\
19 \\
19 \\
--\end{array}$ & $\begin{array}{r}110 \\
110 \\
110 \\
110 \\
110 \\
-- \\
-- \\
-- \\
120 \\
110 \\
110 \\
--\end{array}$ & $\begin{array}{l}4.1 \\
4.1 \\
3.6 \\
3.5 \\
3.4 \\
-- \\
-- \\
-- \\
3.6 \\
7.4 \\
3.7 \\
--\end{array}$ & $\begin{array}{l}190 \\
190 \\
180 \\
190 \\
190 \\
180 \\
190 \\
180 \\
190 \\
180 \\
190 \\
180\end{array}$ & $\begin{array}{r}200 \\
210 \\
210 \\
190 \\
200 \\
-- \\
210 \\
210 \\
200 \\
210 \\
200 \\
200\end{array}$ & $\begin{array}{r}32 \\
33 \\
34 \\
33 \\
34 \\
-- \\
36 \\
38 \\
36 \\
34 \\
34 \\
35\end{array}$ & $\begin{array}{l}470 \\
480 \\
470 \\
460 \\
500 \\
490 \\
460 \\
450 \\
490 \\
480 \\
450 \\
480\end{array}$ & $\begin{array}{l}-- \\
-- \\
-- \\
-- \\
-- \\
-- \\
-- \\
-- \\
-- \\
-- \\
--\end{array}$ & $\begin{array}{r}86 \\
85 \\
274 \\
87 \\
86 \\
88 \\
88 \\
88 \\
87 \\
89 \\
86 \\
87\end{array}$ \\
\hline $\begin{array}{l}343124117143002 \\
\quad(80 \mathrm{ft})\end{array}$ & $\begin{array}{l}-- \\
-- \\
-- \\
-- \\
-- \\
-- \\
-- \\
-- \\
-- \\
-- \\
-- \\
--\end{array}$ & $\begin{array}{l}-- \\
-- \\
-- \\
-- \\
-- \\
-- \\
-- \\
-- \\
-- \\
-- \\
-- \\
--\end{array}$ & $\begin{array}{l}-- \\
-- \\
-- \\
-- \\
-- \\
-- \\
-- \\
-- \\
-- \\
-- \\
--\end{array}$ & $\begin{array}{r}120 \\
110 \\
100 \\
75 \\
64 \\
56 \\
-- \\
50 \\
50 \\
-- \\
49 \\
--\end{array}$ & $\begin{array}{r}170 \\
160 \\
160 \\
120 \\
120 \\
-- \\
-- \\
160 \\
170 \\
-- \\
210 \\
--\end{array}$ & $\begin{array}{r}98 \\
95 \\
160 \\
23 \\
98 \\
-- \\
-- \\
100 \\
98 \\
-- \\
96 \\
--\end{array}$ & $\begin{array}{r}2,100 \\
1,100 \\
2,600 \\
2,800 \\
3,300 \\
3,500 \\
-- \\
3,700 \\
4,000 \\
- \\
3,700 \\
--\end{array}$ & $\begin{array}{l}-- \\
-- \\
-- \\
- \\
-- \\
-- \\
-- \\
- \\
-- \\
- \\
-\end{array}$ & $\begin{array}{r}242 \\
226 \\
235 \\
229 \\
229 \\
226 \\
-- \\
215 \\
211 \\
-- \\
210 \\
--\end{array}$ \\
\hline $\begin{array}{l}343123117143003 \\
\quad(48 \mathrm{ft})\end{array}$ & $\begin{array}{l}16 \\
-- \\
-- \\
-- \\
--\end{array}$ & $\begin{array}{r}150 \\
-- \\
-- \\
-- \\
--\end{array}$ & $\begin{array}{l}6.7 \\
-- \\
-- \\
-- \\
--\end{array}$ & $\begin{array}{r}120 \\
120 \\
-- \\
100 \\
--\end{array}$ & $\begin{array}{r}160 \\
250 \\
-- \\
290 \\
-.\end{array}$ & $\begin{array}{r}94 \\
93 \\
-- \\
98 \\
--\end{array}$ & $\begin{array}{r}2,000 \\
640 \\
-- \\
760 \\
--\end{array}$ & $\begin{array}{l}-- \\
-- \\
-- \\
--\end{array}$ & $\begin{array}{r}240 \\
405 \\
-- \\
351 \\
--\end{array}$ \\
\hline $\begin{array}{l}343124117143004 \\
\quad(33 \mathrm{ft})\end{array}$ & $\begin{array}{r}-- \\
27 \\
26 \\
25 \\
25 \\
26 \\
-- \\
--\end{array}$ & $\begin{array}{r}-- \\
280 \\
240 \\
210 \\
200 \\
180 \\
-- \\
--\end{array}$ & $\begin{array}{c}-- \\
13 \\
10 \\
10 \\
8.8 \\
8.1 \\
-- \\
--\end{array}$ & $\begin{array}{r}-- \\
150 \\
120 \\
100 \\
88 \\
74 \\
66 \\
62\end{array}$ & $\begin{array}{r}-- \\
400 \\
330 \\
290 \\
260 \\
230 \\
-- \\
270\end{array}$ & $\begin{array}{r}-- \\
100 \\
97 \\
95 \\
96 \\
96 \\
-- \\
100\end{array}$ & $\begin{array}{r}-- \\
740 \\
800 \\
820 \\
840 \\
930 \\
980 \\
910\end{array}$ & $\begin{array}{l}-- \\
-- \\
-- \\
-- \\
-- \\
-- \\
-- \\
--\end{array}$ & $\begin{array}{r}-- \\
544 \\
496 \\
560 \\
489 \\
473 \\
462 \\
454\end{array}$ \\
\hline $\begin{array}{l}343124117143005 \\
\quad \text { (lateral-flow } \\
\text { hole, } 48 \mathrm{ft} \text { ) }\end{array}$ & 36 & 320 & 11 & 190 & 570 & 98 & 680 & -- & 347 \\
\hline
\end{tabular}


Table 10. Chemical analyses of samples from suction lysimeters--Continued

\begin{tabular}{|c|c|c|c|c|c|c|c|c|c|}
\hline $\begin{array}{c}\text { USGS site } \\
\text { identification } \\
\text { No. } \\
\text { (lysimeter } \\
\text { depth) }\end{array}$ & Date & $\begin{array}{l}\text { Temper- } \\
\text { ature, } \\
\text { water } \\
\left({ }^{\circ} \mathrm{C}\right)\end{array}$ & $\begin{array}{l}\text { Specific } \\
\text { conduct- } \\
\text { ance } \\
(\mu \mathrm{S} / \mathrm{cm})\end{array}$ & $\begin{array}{l}\text { Nitro- } \\
\text { gen } \\
(\mathrm{mg} / \mathrm{L} \\
\text { as } \mathrm{N})\end{array}$ & $\begin{array}{l}\text { Nitro- } \\
\text { gen, } \\
\text { organic } \\
(\mathrm{mg} / \mathrm{L} \\
\text { as } \mathrm{N})\end{array}$ & $\begin{array}{l}\text { Nitro- } \\
\text { gen, } \\
\text { ammonia } \\
\text { (mg/L } \\
\text { as N) }\end{array}$ & $\begin{array}{c}\text { Nitro- } \\
\text { gen, } \\
\mathrm{NO}_{2}+\mathrm{NO}_{3} \\
(\mathrm{mg} / \mathrm{L} \\
\text { as } \mathrm{N})\end{array}$ & $\begin{array}{c}\text { Carbon, } \\
\text { organic } \\
\text { total } \\
(\mathrm{mg} / \mathrm{L} \\
\text { as } \mathrm{C})\end{array}$ & $\begin{array}{c}\text { Calcium } \\
(\mathrm{mg} / \mathrm{L})\end{array}$ \\
\hline \multicolumn{10}{|c|}{ Little Beaver site } \\
\hline $\begin{array}{c}342857117120604 \\
(\text { hole } 2,77 \mathrm{ft})\end{array}$ & $1-11-90$ & 24.0 & 2,600 & 24 & 3.4 & 0.22 & 20 & -- & -- \\
\hline $\begin{array}{c}342857117120605 \\
\text { (hole 2, } 67 \mathrm{ft} \text { ) }\end{array}$ & $8-23-89$ & 24.0 & 980 & 21 & .67 & .03 & 20 & -- & -- \\
\hline $\begin{array}{l}342857117120601 \\
\text { (hole } 1,40 \mathrm{ft})\end{array}$ & $\begin{array}{r}9-12-88 \\
10-14-88 \\
2-06-89 \\
3-06-89 \\
4-10-89 \\
5-22-89 \\
7-08-89 \\
8-23-89 \\
1-11-90\end{array}$ & $\begin{array}{l}28.0 \\
27.0 \\
15.0 \\
21.0 \\
21.0 \\
20.0 \\
-\overline{26.5} \\
23.5\end{array}$ & $\begin{array}{r}1,130 \\
1,180 \\
1,080 \\
1,100 \\
880 \\
910 \\
-- \\
1,170 \\
1,100\end{array}$ & $\begin{array}{c}3.4 \\
-- \\
11 \\
5.1 \\
4.0 \\
1.6 \\
3.2 \\
5.9 \\
8.7\end{array}$ & $\begin{array}{l}-- \\
-- \\
.76 \\
.48 \\
1.6 \\
.37 \\
.37 \\
.39 \\
.89\end{array}$ & $\begin{array}{r}<.01 \\
.03 \\
.14 \\
.02 \\
.03 \\
.03 \\
.03 \\
.01 \\
.01\end{array}$ & $\begin{array}{c}3.0 \\
11 \\
9.9 \\
4.6 \\
2.4 \\
1.2 \\
2.8 \\
5.5 \\
7.8\end{array}$ & $\begin{array}{l}-- \\
-- \\
-- \\
- \\
-- \\
-- \\
- \\
-- \\
--\end{array}$ & $\begin{array}{l}-- \\
-- \\
-- \\
-- \\
-- \\
-- \\
-- \\
-- \\
78\end{array}$ \\
\hline $\begin{array}{r}342857117120602 \\
\text { (hole } 1,31.5 \mathrm{ft})\end{array}$ & $\begin{array}{r}6-08-88 \\
6-09-88 \\
7-13-88 \\
8-09-88 \\
9-12-88 \\
10-14-88 \\
2-06-89 \\
03-06-89 \\
4-10-89 \\
5-22-89 \\
7-08-89 \\
8-23-89 \\
1-11-90\end{array}$ & $\begin{array}{l}-- \\
-- \\
25.5 \\
28.0 \\
28.0 \\
27.0 \\
15.0 \\
21.0 \\
21.0 \\
20.0 \\
-- \\
26.5 \\
23.5\end{array}$ & $\begin{array}{r}-- \\
-- \\
1,660 \\
1,120 \\
2,300 \\
2,600 \\
1,080 \\
1,100 \\
2,600 \\
2,500 \\
-- \\
2,500 \\
2,450\end{array}$ & $\begin{array}{c}23 \\
12 \\
13 \\
9.3 \\
16 \\
-- \\
11 \\
5.1 \\
25 \\
22 \\
21 \\
-- \\
13\end{array}$ & $\begin{array}{c}2.0 \\
1.3 \\
1.2 \\
.86 \\
.64 \\
-- \\
.76 \\
.48 \\
.73 \\
.73 \\
1.3 \\
--.98\end{array}$ & $\begin{array}{l}.13 \\
.12 \\
.03 \\
.04 \\
.06 \\
.23 \\
.14 \\
.02 \\
.07 \\
.07 \\
.06 \\
.05 \\
.02\end{array}$ & $\begin{array}{l}21 \\
11 \\
12 \\
8.4 \\
15 \\
28 \\
9.9 \\
4.6 \\
24 \\
21 \\
20 \\
14 \\
12\end{array}$ & $\begin{array}{l}-- \\
-- \\
-- \\
-- \\
-- \\
- \\
-- \\
- \\
-- \\
-- \\
- \\
- \\
-\end{array}$ & $\begin{array}{r}-- \\
-- \\
-- \\
130 \\
-- \\
-- \\
-- \\
-- \\
-- \\
-- \\
-- \\
- \\
--\end{array}$ \\
\hline
\end{tabular}

\begin{tabular}{|c|c|c|c|c|c|c|c|c|c|}
\hline \multicolumn{10}{|c|}{ Kiowa site } \\
\hline \multirow{5}{*}{$\begin{array}{l}342917117122601 \\
(149 \mathrm{ft})\end{array}$} & $6-08-88$ & -- & -- & 6.3 & 1.4 & 0.06 & 4.8 & -- & -- \\
\hline & $8-09-88$ & 28.0 & 1,300 & 4.2 & -- & $<.01$ & 3.1 & -- & -- \\
\hline & $9-12-88$ & -. & -- & 1.7 & -- & $<.01$ & 1.3 & -- & -- \\
\hline & $10-14-88$ & 25.0 & 825 & -- & -- & .04 & 1.3 & -- & -- \\
\hline & $5-22-89$ & 20.0 & 800 & 4.3 & 3.8 & .09 & .42 & -- & -- \\
\hline \multirow{8}{*}{$\begin{array}{l}342917117122602 \\
(107.5 \mathrm{ft})\end{array}$} & $6-02-88$ & -- & -- & 12 & 1.1 & .09 & 11 & -- & -- \\
\hline & $6-08-88$ & -- & -- & 16 & 1.2 & .07 & 15 & -- & -- \\
\hline & $8-09-88$ & 28.0 & 1,340 & 18 & 2.3 & .04 & 16 & -- & -- \\
\hline & $9-12-88$ & 27.0 & 1,240 & 15 & 1.8 & .03 & 13 & -- & -- \\
\hline & $10-14-88$ & 25.0 & 1,210 & -- & -- & .36 & 20 & -- & -- \\
\hline & 2-06-89 & 14.0 & 1,110 & 24 & 6.1 & 2.9 & 15 & -- & -- \\
\hline & $3-06-89$ & 21.0 & 1,220 & 18 & 1.7 & .08 & 16 & -- & -- \\
\hline & $4-10-89$ & 21.0 & 760 & 20 & .97 & .13 & 19 & 8.3 & 82 \\
\hline \multirow{2}{*}{$\begin{array}{l}342917117122603 \\
\quad(67.5 \mathrm{ft})\end{array}$} & $9-12-88$ & 27.0 & 840 & 15 & -- & $<.01$ & 14 & -- & -- \\
\hline & $10-14-88$ & 25.0 & 820 & -- & -- & .04 & 17 & -- & -- \\
\hline \multirow{3}{*}{$\begin{array}{l}342917117122604 \\
\quad(32 \mathrm{ft})\end{array}$} & $10-14-88$ & 25.0 & 1,380 & -. & -- & .03 & 11 & -- & -- \\
\hline & 2-06-89 & 14.0 & 1,290 & 10 & .77 & .03 & 9.6 & -- & -- \\
\hline & 3-06-89 & 21.0 & 1,190 & 7.7 & .67 & .03 & 7.0 & -. & -- \\
\hline
\end{tabular}


Table 10. Chemical analyses of samples from suction lysimeters--Continued

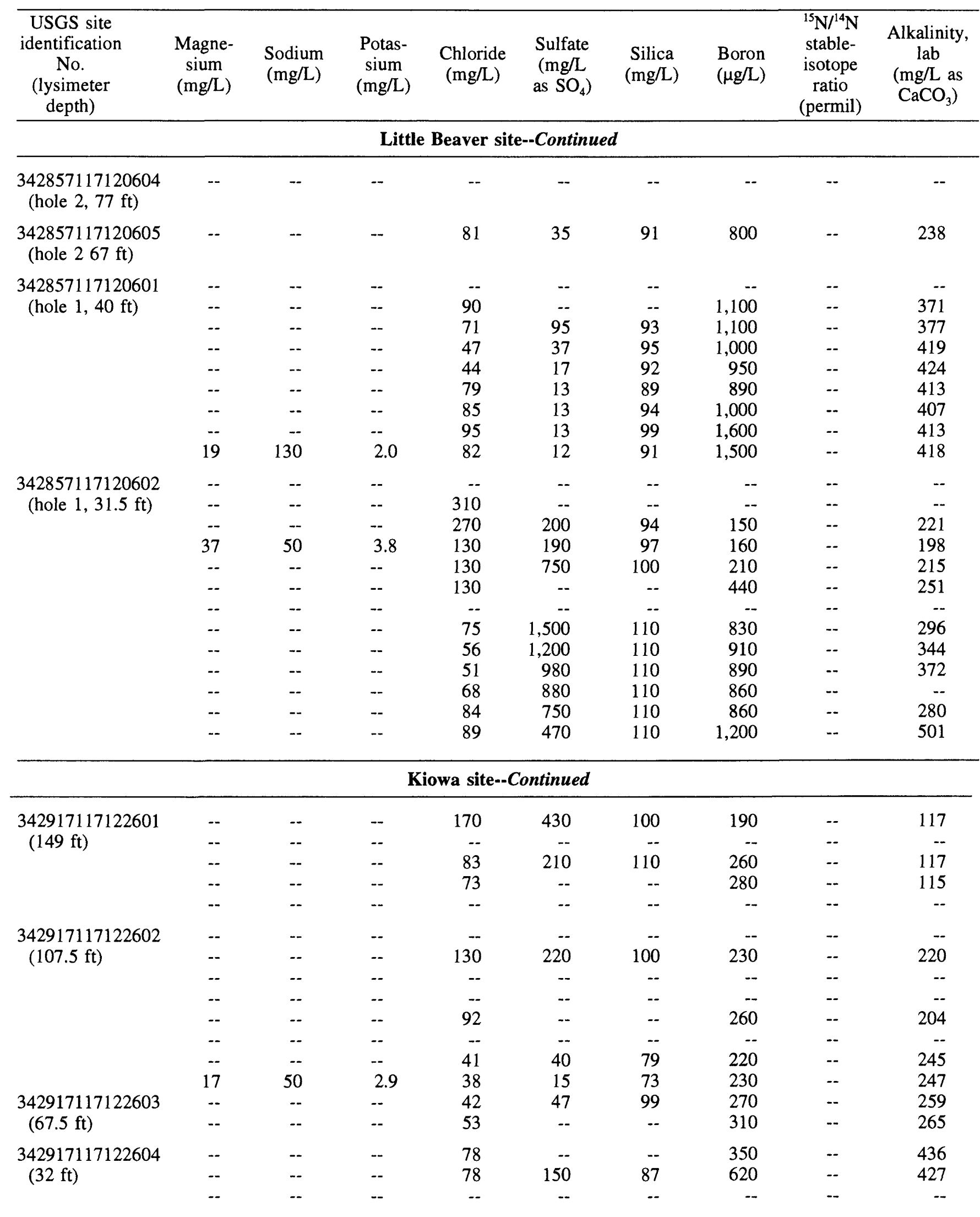


Table 10. Chemical analyses of samples from suction lysimeters--Continued

\begin{tabular}{|c|c|c|c|c|c|c|c|c|c|}
\hline $\begin{array}{c}\text { USGS site } \\
\text { identification } \\
\text { No. } \\
\text { (lysimeter } \\
\text { depth) }\end{array}$ & Date & $\begin{array}{c}\text { Temper- } \\
\text { ature, } \\
\text { water } \\
\left({ }^{\circ} \mathrm{C}\right)\end{array}$ & $\begin{array}{c}\text { Specific } \\
\text { conduct- } \\
\text { ance } \\
(\mu \mathrm{S} / \mathrm{cm})\end{array}$ & $\begin{array}{l}\text { Nitro- } \\
\text { gen } \\
(\mathrm{mg} / \mathrm{L} \\
\text { as } \mathrm{N})\end{array}$ & $\begin{array}{l}\text { Nitro- } \\
\text { gen, } \\
\text { organic } \\
\text { (mg/L } \\
\text { as N) }\end{array}$ & $\begin{array}{c}\text { Nitro- } \\
\text { gen, } \\
\text { ammonia } \\
(\mathrm{mg} / \mathrm{L} \\
\text { as } \mathrm{N})\end{array}$ & $\begin{array}{c}\text { Nitro- } \\
\text { gen, } \\
\mathrm{NO}_{2}+\mathrm{NO}_{3} \\
(\mathrm{mg} / \mathrm{L} \\
\text { as } \mathrm{N})\end{array}$ & $\begin{array}{c}\text { Carbon, } \\
\text { organic } \\
\text { total } \\
\text { (mg/L } \\
\text { as } \mathrm{C} \text { ) }\end{array}$ & $\begin{array}{c}\text { Calcium } \\
(\mathrm{mg} / \mathrm{L})\end{array}$ \\
\hline \multicolumn{10}{|c|}{ Cheyenne-II site } \\
\hline $\begin{array}{l}343114117122303 \\
(67 \mathrm{ft})\end{array}$ & $\begin{array}{r}5-13-88 \\
6-02-88 \\
6-08-88 \\
6-09-88 \\
7-13-88 \\
8-08-88 \\
9-12-88 \\
10-14-88 \\
1-27-89 \\
3-06-89 \\
4-10-89 \\
5-22-89\end{array}$ & $\begin{array}{l}-- \\
-- \\
-- \\
-- \\
24.5 \\
34.0 \\
28.0 \\
25.0 \\
24.0 \\
23.0 \\
21.0 \\
20.0\end{array}$ & $\begin{array}{r}-- \\
-- \\
-- \\
-- \\
1,700 \\
1,600 \\
1,790 \\
1,590 \\
1,500 \\
1,460 \\
1,550 \\
1,500\end{array}$ & $\begin{array}{r}34 \\
35 \\
43 \\
42 \\
46 \\
45 \\
-- \\
-- \\
37 \\
46 \\
49 \\
54\end{array}$ & $\begin{array}{l}1.9 \\
3.2 \\
1.0 \\
1.0 \\
-- \\
1.1 \\
-- \\
-- \\
1.9 \\
1.4 \\
1.4 \\
1.5\end{array}$ & $\begin{array}{r}0.06 \\
.06 \\
.06 \\
.06 \\
<.01 \\
.08 \\
<.01 \\
.03 \\
.03 \\
.04 \\
.05 \\
.06\end{array}$ & $\begin{array}{l}32 \\
32 \\
42 \\
41 \\
45 \\
44 \\
31 \\
45 \\
35 \\
45 \\
48 \\
52\end{array}$ & $\begin{array}{l}-- \\
-- \\
-- \\
-- \\
-- \\
-- \\
-- \\
-- \\
- \\
- \\
-\end{array}$ & $\begin{array}{r}230 \\
190 \\
-- \\
170 \\
150 \\
160 \\
-- \\
-- \\
-- \\
-- \\
--\end{array}$ \\
\hline \multicolumn{10}{|c|}{ Cajon site } \\
\hline $\begin{array}{c}342518117160601 \\
(257 \mathrm{ft}) \\
\text { [within } \\
\text { saturated } \\
\text { zone] }\end{array}$ & $\begin{array}{l}2-06-89 \\
3-07-89 \\
4-12-89 \\
8-22-89 \\
1-11-90\end{array}$ & $\begin{array}{l}10.0 \\
20.0 \\
21.0 \\
22.0 \\
23.0\end{array}$ & $\begin{array}{r}660 \\
710 \\
1,500 \\
490 \\
510\end{array}$ & $\begin{array}{c}4.3 \\
4.5 \\
14 \\
3.0 \\
--\end{array}$ & $\begin{array}{c}0.75 \\
.20 \\
1.0 \\
.10 \\
. .\end{array}$ & $\begin{array}{l}0.55 \\
1.2 \\
.18 \\
1.8 \\
--\end{array}$ & $\begin{array}{c}3 \\
3.1 \\
13 \\
1.1 \\
--\end{array}$ & $\begin{array}{c}-- \\
-- \\
-- \\
-- \\
15\end{array}$ & $\begin{array}{l}-- \\
-- \\
-- \\
-- \\
-\end{array}$ \\
\hline $\begin{array}{l}342518117160602 \\
\quad(243 \mathrm{ft})\end{array}$ & $\begin{array}{l}8-22-89 \\
1-11-90 \\
5-04-90 \\
5-18-90 \\
6-12-90\end{array}$ & $\begin{array}{l}22.0 \\
23.0 \\
-- \\
-- \\
--\end{array}$ & $\begin{array}{r}2,250 \\
2,300 \\
-- \\
-- \\
--\end{array}$ & $\begin{array}{l}3.1 \\
1.9 \\
-- \\
-- \\
--\end{array}$ & $\begin{array}{l}.88 \\
.81 \\
-- \\
-- \\
--\end{array}$ & $\begin{array}{l}.62 \\
.19 \\
.17 \\
.17 \\
.21\end{array}$ & $\begin{array}{l}1.6 \\
.93 \\
1.8 \\
1.1 \\
.8\end{array}$ & $\begin{array}{l}-- \\
6.1 \\
-- \\
-- \\
--\end{array}$ & $\begin{array}{l}-- \\
-- \\
-- \\
-- \\
--\end{array}$ \\
\hline $\begin{array}{l}342518117160603 \\
(199 \mathrm{ft})\end{array}$ & $\begin{array}{l}8-22-89 \\
1-11-90\end{array}$ & $\begin{array}{l}22.0 \\
23.0\end{array}$ & $\begin{array}{l}550 \\
610\end{array}$ & $\begin{array}{l}16 \\
16\end{array}$ & $\begin{array}{l}.53 \\
.66\end{array}$ & $\begin{array}{l}.07 \\
.14\end{array}$ & $\begin{array}{l}15 \\
15\end{array}$ & $\overline{4.0}$ & $\begin{array}{l}-- \\
--\end{array}$ \\
\hline $\begin{array}{l}342518117160604 \\
(160 \mathrm{ft})\end{array}$ & $1-11-90$ & 23.0 & 1,200 & 37 & 1.3 & .44 & 35 & 7.6 & -- \\
\hline $\begin{array}{l}342518117160605 \\
\quad(130 \mathrm{ft})\end{array}$ & $\begin{array}{l}4-10-89 \\
7-08-89 \\
8-22-89 \\
1-11-90\end{array}$ & $\begin{array}{c}20.0 \\
- \\
22.0 \\
23.0\end{array}$ & $\begin{array}{r}760 \\
-- \\
660 \\
710\end{array}$ & $\begin{array}{l}35 \\
38 \\
34 \\
--\end{array}$ & $\begin{array}{l}.87 \\
1.2 \\
1.1 \\
--\end{array}$ & $\begin{array}{r}.33 \\
.92 \\
.31 \\
--\end{array}$ & $\begin{array}{r}34 \\
36 \\
33 \\
--\end{array}$ & $\begin{array}{c}-- \\
-- \\
-- \\
15\end{array}$ & $\begin{array}{l}-- \\
-- \\
-- \\
--\end{array}$ \\
\hline $\begin{array}{l}342518117160606 \\
(97.5 \mathrm{ft})\end{array}$ & $\begin{array}{l}4-10-89 \\
7-08-89 \\
8-22-89 \\
1-11-90\end{array}$ & $\begin{array}{l}21.0 \\
-\overline{22.0} \\
23.0\end{array}$ & $\begin{array}{r}520 \\
-- \\
530 \\
580\end{array}$ & $\begin{array}{l}31 \\
35 \\
32 \\
36\end{array}$ & $\begin{array}{l}1.6 \\
1.4 \\
.52 \\
1.3\end{array}$ & $\begin{array}{l}.20 \\
.44 \\
.18 \\
.40\end{array}$ & $\begin{array}{l}29 \\
33 \\
31 \\
34\end{array}$ & $\begin{array}{l}7.7 \\
-- \\
-- \\
5.6\end{array}$ & $\begin{array}{c}26 \\
28 \\
-- \\
56\end{array}$ \\
\hline $\begin{array}{l}342518117160607 \\
\quad(70 \mathrm{ft})\end{array}$ & $\begin{array}{l}4-10-89 \\
7-08-89 \\
8-22-89 \\
1-11-90\end{array}$ & $\begin{array}{l}20.0 \\
-\overline{22.0} \\
23.0\end{array}$ & $\begin{array}{r}750 \\
-- \\
720 \\
710\end{array}$ & $\begin{array}{c}32 \\
32 \\
30 \\
6.7\end{array}$ & $\begin{array}{l}1.6 \\
1.2 \\
1.2 \\
1.3\end{array}$ & $\begin{array}{l}.03 \\
.57 \\
.37 \\
.09\end{array}$ & $\begin{array}{c}30 \\
30 \\
28 \\
5.3\end{array}$ & $\begin{array}{l}-- \\
-- \\
-- \\
3.9\end{array}$ & $\begin{array}{l}-- \\
-- \\
-- \\
--\end{array}$ \\
\hline $\begin{array}{l}342518117160608 \\
\quad(35 \mathrm{ft})\end{array}$ & $\begin{array}{l}2-06-89 \\
3-07-89\end{array}$ & $\begin{array}{l}10.0 \\
20.0\end{array}$ & $\begin{array}{r}980 \\
1,110\end{array}$ & $\begin{array}{l}27 \\
39\end{array}$ & $\begin{array}{l}1.9 \\
1.4\end{array}$ & $\begin{array}{l}.05 \\
.06\end{array}$ & $\begin{array}{l}25 \\
37\end{array}$ & $\begin{array}{l}-- \\
--\end{array}$ & $\overline{76}$ \\
\hline
\end{tabular}


Table 10. Chemical analyses of samples from suction lysimeters--Continued

\begin{tabular}{|c|c|c|c|c|c|c|c|c|c|}
\hline $\begin{array}{c}\text { USGS site } \\
\text { identification } \\
\text { No. } \\
\text { (lysimeter } \\
\text { depth) } \\
\end{array}$ & $\begin{array}{c}\text { Magne- } \\
\text { sium } \\
(\mathrm{mg} / \mathrm{L})\end{array}$ & $\begin{array}{l}\text { Sodium } \\
(\mathrm{mg} / \mathrm{L})\end{array}$ & $\begin{array}{l}\text { Potas- } \\
\text { sium } \\
(\mathrm{mg} / \mathrm{L})\end{array}$ & $\begin{array}{l}\text { Chloride } \\
\text { (mg/L) }\end{array}$ & $\begin{array}{c}\text { Sulfate } \\
(\mathrm{mg} / \mathrm{L} \\
\left.\text { as } \mathrm{SO}_{4}\right)\end{array}$ & $\begin{array}{l}\text { Silica } \\
(\mathrm{mg} / \mathrm{L})\end{array}$ & $\begin{array}{l}\text { Boron } \\
(\mu \mathrm{g} / \mathrm{L})\end{array}$ & $\begin{array}{l}{ }^{15} \mathrm{~N} /{ }^{14} \mathrm{~N} \\
\text { stable- } \\
\text { isotope } \\
\text { ratio } \\
\text { (permil) }\end{array}$ & $\begin{array}{c}\text { Alkalinity, } \\
\text { lab } \\
(\mathrm{mg} / \mathrm{L} \text { as } \\
\left.\mathrm{CaCO}_{3}\right)\end{array}$ \\
\hline \multicolumn{10}{|c|}{ Cheyenne-II site--Continued } \\
\hline $\begin{array}{l}343114117122303 \\
(67 \mathrm{ft})\end{array}$ & $\begin{array}{c}-- \\
62 \\
59 \\
-- \\
50 \\
46 \\
52 \\
-- \\
-- \\
-- \\
-- \\
--\end{array}$ & $\begin{array}{r}-- \\
160 \\
140 \\
-- \\
120 \\
100 \\
120 \\
- \\
-- \\
-- \\
-- \\
--\end{array}$ & $\begin{array}{l}-- \\
8.3 \\
6.7 \\
-- \\
5.3 \\
4.3 \\
4.0 \\
-- \\
-- \\
-- \\
-- \\
--\end{array}$ & $\begin{array}{l}380 \\
370 \\
240 \\
190 \\
180 \\
150 \\
180 \\
170 \\
170 \\
190 \\
190 \\
200\end{array}$ & $\begin{array}{r}390 \\
430 \\
340 \\
-- \\
230 \\
160 \\
160 \\
-- \\
96 \\
86 \\
83 \\
120\end{array}$ & $\begin{array}{c}88 \\
90 \\
92 \\
-- \\
94 \\
89 \\
80 \\
-- \\
85 \\
85 \\
81 \\
74\end{array}$ & $\begin{array}{r}<10 \\
490 \\
760 \\
-- \\
930 \\
880 \\
870 \\
840 \\
770 \\
730 \\
800 \\
780\end{array}$ & $\begin{array}{l}-- \\
-- \\
-- \\
-- \\
-- \\
-- \\
-- \\
-- \\
-- \\
-- \\
-- \\
--\end{array}$ & $\begin{array}{r}148 \\
157 \\
230 \\
-- \\
506 \\
274 \\
131 \\
300 \\
294 \\
323 \\
311 \\
259\end{array}$ \\
\hline \multicolumn{10}{|c|}{ Cajon site--Continued } \\
\hline $\begin{array}{l}342518117160601 \\
(257 \mathrm{ft}) \\
\text { [within } \\
\text { saturated } \\
\text { zone] }\end{array}$ & $\begin{array}{l}-- \\
-- \\
-- \\
-- \\
--\end{array}$ & $\begin{array}{l}-- \\
- \\
-- \\
- \\
--\end{array}$ & $\begin{array}{l}-- \\
- \\
-- \\
- \\
--\end{array}$ & $\begin{array}{r}130 \\
\ldots \\
380 \\
69 \\
--\end{array}$ & $\begin{array}{r}55 \\
51 \\
150 \\
39 \\
--\end{array}$ & $\begin{array}{r}12 \\
16 \\
29 \\
14 \\
--\end{array}$ & $\begin{array}{r}60 \\
20 \\
190 \\
20 \\
--\end{array}$ & $\begin{array}{l}-- \\
-- \\
-- \\
-- \\
--\end{array}$ & $\begin{array}{r}63 \\
88 \\
89 \\
89 \\
--\end{array}$ \\
\hline $\begin{array}{l}342518117160602 \\
(243 \mathrm{ft})\end{array}$ & $\begin{array}{l}-- \\
-- \\
-- \\
-- \\
--\end{array}$ & $\begin{array}{l}-- \\
-- \\
-- \\
-- \\
--\end{array}$ & $\begin{array}{l}-- \\
-- \\
-- \\
-- \\
--\end{array}$ & $\begin{array}{r}370 \\
71 \\
-- \\
-- \\
--\end{array}$ & $\begin{array}{r}260 \\
130 \\
-- \\
-- \\
--\end{array}$ & $\begin{array}{l}74 \\
78 \\
-- \\
-- \\
--\end{array}$ & $\begin{array}{r}130 \\
40 \\
-- \\
-- \\
--\end{array}$ & $\begin{array}{l}-. \\
-- \\
-- \\
-- \\
7.10\end{array}$ & $\begin{array}{r}318 \\
87 \\
-- \\
-- \\
--\end{array}$ \\
\hline $\begin{array}{l}342518117160603 \\
(199 \mathrm{ft})\end{array}$ & $\begin{array}{l}-- \\
--\end{array}$ & $\begin{array}{l}-- \\
--\end{array}$ & $\begin{array}{l}-- \\
--\end{array}$ & $\begin{array}{l}53 \\
46\end{array}$ & $\begin{array}{l}49 \\
42\end{array}$ & $\begin{array}{l}91 \\
85\end{array}$ & $\begin{array}{l}40 \\
40\end{array}$ & $\begin{array}{l}-- \\
--\end{array}$ & $\begin{array}{l}52 \\
44\end{array}$ \\
\hline $\begin{array}{l}342518117160604 \\
(160 \mathrm{ft})\end{array}$ & -- & -- & -- & -- & -- & -- & -- & -- & -- \\
\hline $\begin{array}{l}342518117160605 \\
(130 \mathrm{ft})\end{array}$ & $\begin{array}{l}-- \\
-- \\
-- \\
--\end{array}$ & $\begin{array}{l}-- \\
-- \\
-- \\
--\end{array}$ & $\begin{array}{l}-- \\
-- \\
-- \\
--\end{array}$ & $\begin{array}{r}40 \\
35 \\
33 \\
--\end{array}$ & $\begin{array}{r}74 \\
92 \\
66 \\
--\end{array}$ & $\begin{array}{c}94 \\
90 \\
86 \\
--\end{array}$ & $\begin{array}{c}40 \\
20 \\
30 \\
--\end{array}$ & $\begin{array}{l}-- \\
-- \\
-- \\
--\end{array}$ & $\begin{array}{r}95 \\
59 \\
45 \\
--\end{array}$ \\
\hline $\begin{array}{l}342518117160606 \\
(97.5 \mathrm{ft})\end{array}$ & $\begin{array}{c}7.3 \\
8.1 \\
-- \\
15\end{array}$ & $\begin{array}{r}54 \\
52 \\
-- \\
95\end{array}$ & $\begin{array}{l}1.8 \\
1.5 \\
-- \\
4.3\end{array}$ & $\begin{array}{l}32 \\
32 \\
34 \\
37\end{array}$ & $\begin{array}{l}22 \\
16 \\
17 \\
16\end{array}$ & $\begin{array}{l}54 \\
55 \\
58 \\
81\end{array}$ & $\begin{array}{l}80 \\
90 \\
90 \\
90\end{array}$ & $\begin{array}{l}-- \\
-- \\
-- \\
--\end{array}$ & $\begin{array}{l}30 \\
26 \\
26 \\
30\end{array}$ \\
\hline $\begin{array}{l}342518117160607 \\
(70 \mathrm{ft})\end{array}$ & $\begin{array}{l}-- \\
-- \\
-- \\
--\end{array}$ & $\begin{array}{l}-- \\
-- \\
-- \\
--\end{array}$ & $\begin{array}{l}-- \\
-- \\
-- \\
--\end{array}$ & $\begin{array}{l}35 \\
35 \\
33 \\
46\end{array}$ & $\begin{array}{r}82 \\
120 \\
110 \\
88\end{array}$ & $\begin{array}{l}98 \\
87 \\
89 \\
82\end{array}$ & $\begin{array}{l}70 \\
70 \\
80 \\
80\end{array}$ & $\begin{array}{l}-- \\
-- \\
-- \\
--\end{array}$ & $\begin{array}{r}116 \\
59 \\
55 \\
52\end{array}$ \\
\hline $\begin{array}{l}342518117160608 \\
(35 \mathrm{ft})\end{array}$ & $\overline{16}$ & 160 & $\overline{4.3}$ & $\begin{array}{l}50 \\
87\end{array}$ & $\begin{array}{l}150 \\
230\end{array}$ & $\begin{array}{r}110 \\
85\end{array}$ & $\begin{array}{r}110 \\
60\end{array}$ & $\begin{array}{l}-- \\
--\end{array}$ & $\begin{array}{l}258 \\
156\end{array}$ \\
\hline
\end{tabular}


Suction lysimeters provide the only practical means for obtaining an in situ water sample from the deep unsaturated zone. However, some investigators have questioned whether the chemical quality of lysimeter samples is representative of the soil water. Possible problems include contamination of the sample by lysimeter materials, variability of intake rates of the lysimeters, inability to collect sufficient sample volume, inhomogeneities in the flow regime, and the effects of chemical disequilibrium conditions. A study by Peters and Healy (1988) demonstrated that for nondilute solutions, samples from suction lysimeters that measured major cation and anion concentrations were representative of the natural soil water; however, trace-metal concentrations could be significantly altered by this collection procedure at low concentrations. It was found in this study of the upper Mojave River Basin that once the lysimeter system had been thoroughly flushed by collection of several samples, chemical composition, especially as measured by specific conductance, approached a steadystate value. Unfortunately, the approximately 1-year period for which monitoring was originally budgeted for this study is shorter than ideal, and the frequency of sample collection and analysis may have been too low. The much greater constancy in data acquired after monitoring was resumed at the Cajon site in 1991 , as well as the long time required for downward movement of the wastewater (Schroeder and others, 1993), indicates that monitoring should proceed for a few years. It also is probable that the lower variability in concentrations within the wastewater zone is partly due to sample collection by a single individual when monitoring was resumed in 1991 as opposed to collection by several individuals before then.

\section{ANALYSIS OF TAPWATER AND WASTEWATER}

Water quality was determined in the tapwater (collected from outdoor taps) supplied to the eight residences. The results, given in table 11 , can be used to quantify water-quality changes as the water is used and disposed. The wide range in specific conductance of tapwater, from about $200 \mu \mathrm{S} / \mathrm{cm}$ at Toltec, Vasquez, Choctaw, and Cajon to more than 700 $\mu \mathrm{S} / \mathrm{cm}$ at Cheyenne-I and -II, reflects areal variations in ground-water quality in the study area that are discussed in the "Ground-Water Quality" section and portrayed in figure 8 . Note that nitrate concentration is very low (0.4 to $1.3 \mathrm{mg} / \mathrm{L}$ as $\mathrm{N}$, rounded) at all sites (table 11). Data for a few of the minor (or trace) constituents at the new residences-for example, zinc at Toltec-likely were influenced by leaching from new pipes at the time of sample collection.
Wastewater quality was determined on samples from septic tanks and (or) seepage pits at five of the residential sites (table 12). Access to the disposal systems was achieved by removing about $3 \mathrm{ft}$ of dirt and lifting off the concrete covers. Samples were collected by dipping a glass jar into the wastewater. Access to the seepage pit at Vasquez was through a tube extended to land surface, and sampling was accomplished by lowering a bottom-filling glass bailer with glass-ball check valve. At the time of sample collection at Vasquez, the residence had been occupied for only a short time and the seepage pit contained only a few inches of wastewater. For wastewater samples analyzed for inorganic constituents and organic carbon, solids were removed by centrifugation. Specific organic compound (priority pollutant) analyses were on raw (uncentrifuged) samples, and these results are presented in a later section of this report.

Results of analyses for total bacteria and fecal coliform in wastewater from septic tanks at four residences and from seepage pits at Vasquez and Cheyenne-II are presented in table 13. Methods of analysis were similar to those used for soil samples, and results are expressed in colony-forming units (CFU) per $100 \mathrm{~mL}$ of wastewater.

\section{ANALYSIS OF SHALLOW-GROUND-WATER QUALITY}

Results of ground-water-quality analyses from the multiple-well monitoring sites are given in table 14 . These sites consist of three to four 2-inch polyvinyl chloride monitoring wells installed at different depths in the same hole. Perforated intervals of the wells are isolated from one another by low-permeability bentonite grout. A typical multiple-well monitoring site is depicted in figure 11 .

Ground water from just below the water table at four of the residential sites also was analyzed. Samples were obtained from a well point attached to the bottom of the neutron-access tube at Cheyenne-II (119 to $123 \mathrm{ft}$ ); from suction lysimeters at Cheyenne-I $(113 \mathrm{ft})$, Choctaw (131 ft), and Cajon $(257 \mathrm{ft})$; and from a core recovered during drilling at Cheyenne-I $(124 \mathrm{ft})$. Although data from the ground-water sample recovered during drilling at Cheyenne-I are included in table 13 , it is noted that a sample obtained in this manner is less reliable than one obtained from a permanent well or suction lysimeter because the drill auger mixed soil and water in varying proportions from over a fairly broad depth zone. 


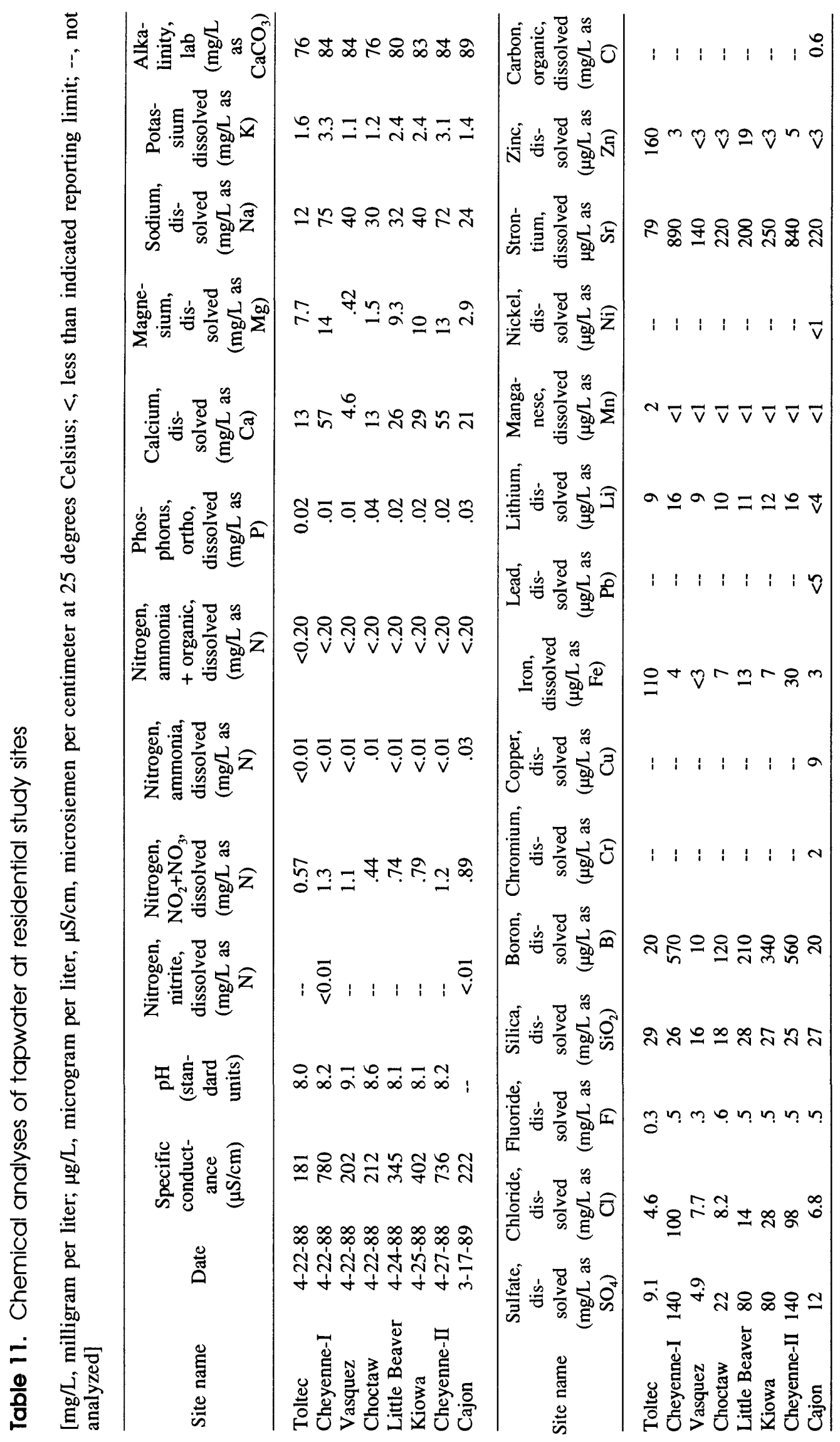




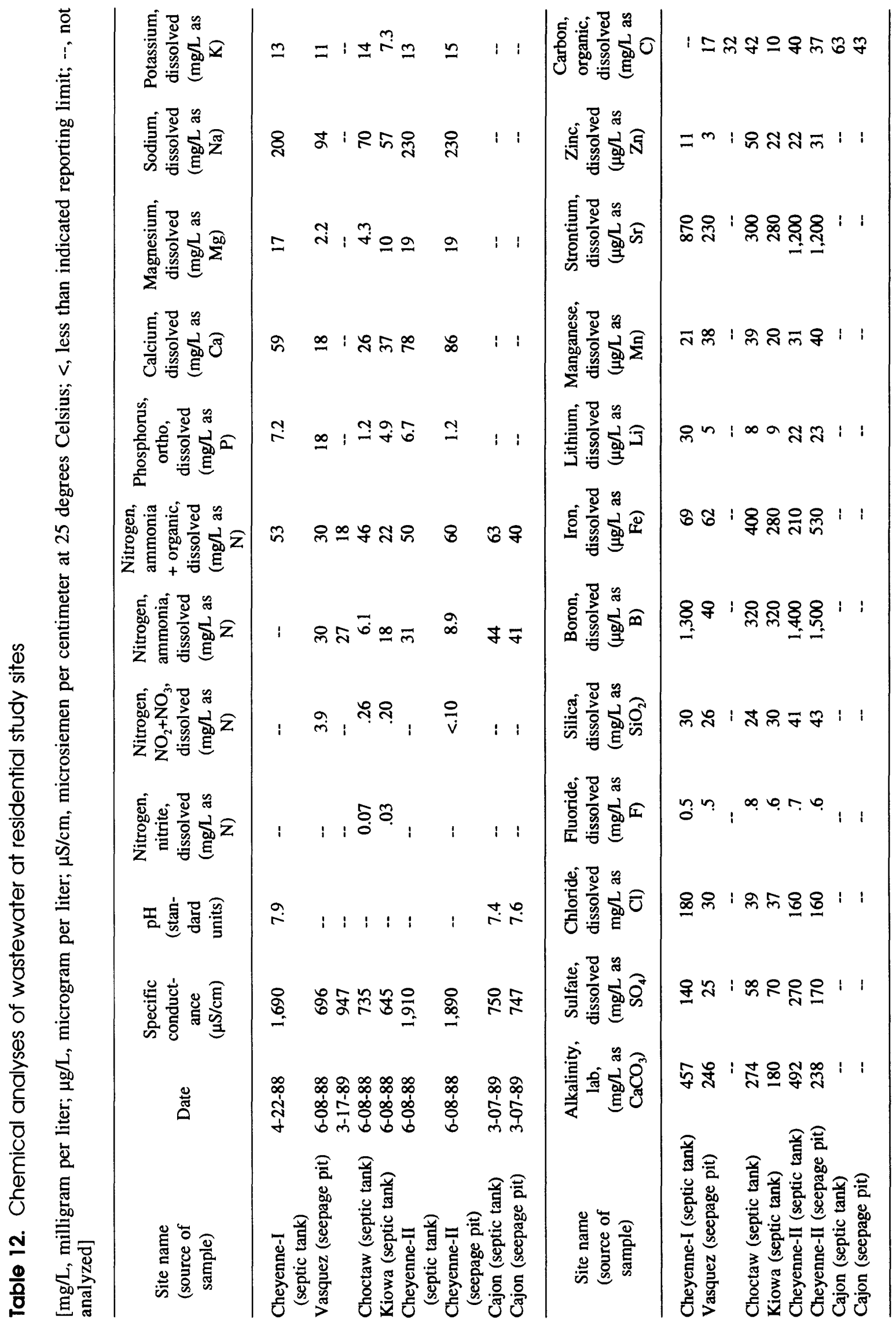


Table 13. Fecal coliform and total bacteria (from standard plate count) in wastewater from septic tanks and seepage pits

[CFU/100 mL, colony-forming units per 100 milliliters wastewater]

\begin{tabular}{cccc}
\hline $\begin{array}{c}\text { Site } \\
\text { name }\end{array}$ & $\begin{array}{c}\text { Sample } \\
\text { date }\end{array}$ & $\begin{array}{c}\text { Fecal } \\
\text { coliform } \\
(\mathrm{CFU} / 100 \\
\mathrm{mL})\end{array}$ & $\begin{array}{c}\text { Total } \\
\text { bacteria } \\
(\mathrm{CFU} / 100 \\
\mathrm{mL})\end{array}$ \\
\hline $\begin{array}{c}\text { Cheyenne-I } \\
\text { (septic tank) }\end{array}$ & $4-22-88$ & $2.5 \times 10^{5}$ & $9.4 \times 10^{8}$ \\
$\begin{array}{c}\text { Choctaw } \\
\text { (septic tank) }\end{array}$ & $6-8-88$ & $6.8 \times 10^{4}$ & $1.2 \times 10^{8}$ \\
$\begin{array}{c}\text { Kiowa } \\
\text { (septic tank) }\end{array}$ & $6-8-88$ & $3.9 \times 10^{5}$ & $3.7 \times 10^{8}$ \\
$\begin{array}{c}\text { Cheyenne-II } \\
\text { (septic tank) }\end{array}$ & $6-8-88$ & $3.3 \times 10^{5}$ & $4.1 \times 10^{8}$ \\
$\begin{array}{c}\text { Cheyenne-II } \\
\text { (seepage pit) }\end{array}$ & $6-8-88$ & $2.8 \times 10^{5}$ & $8.1 \times 10^{8}$ \\
$\begin{array}{c}\text { Vasquez } \\
\text { (seepage pit) }\end{array}$ & $6-8-88$ & $5.2 \times 10^{4}$ & $5.5 \times 10^{8}$ \\
\hline
\end{tabular}

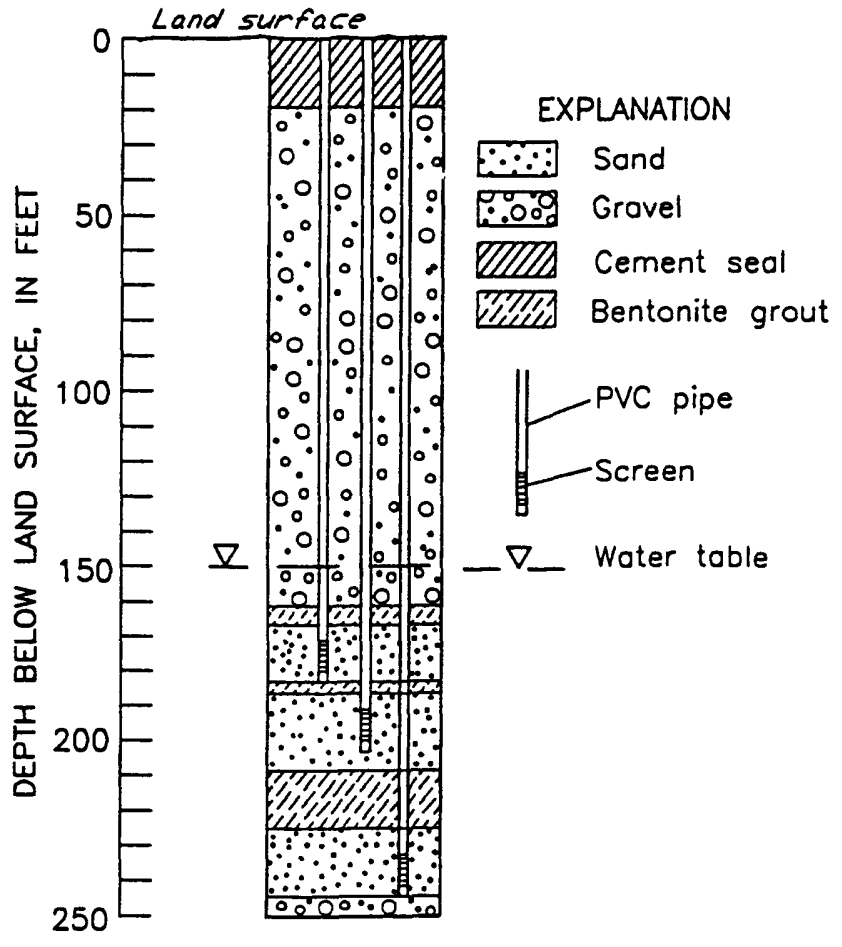

Figure 11. Construction of a typical multiple-well monitoring site.

Table 14. Chemical analyses of ground water from selected residential study sites and multiple-well monitoring sites

[ft, foot; $\mathrm{mg} / \mathrm{L}$, milligram per liter; $\mu \mathrm{g} / \mathrm{L}$, microgram per liter; $\mu \mathrm{S} / \mathrm{cm}$, microsiemen per centimeter at 25 degrees Celsius; ${ }^{\circ} \mathrm{C}$, degrees Celsius. <, less than indicated reporting limit]

\begin{tabular}{|c|c|c|c|c|c|c|c|c|c|}
\hline $\begin{array}{c}\text { Site name } \\
\text { (source of } \\
\text { sample) }\end{array}$ & $\begin{array}{l}\text { Depth } \\
\text { (ft) }\end{array}$ & Date & $\begin{array}{l}\text { Temper- } \\
\text { ature, } \\
\text { water } \\
\left({ }^{\circ} \mathrm{C}\right)\end{array}$ & $\begin{array}{l}\text { Specific } \\
\text { conduct- } \\
\text { ance } \\
(\mu \mathrm{S} / \mathrm{cm})\end{array}$ & $\begin{array}{l}\mathrm{pH} \\
\text { (stan- } \\
\text { dard } \\
\text { units) }\end{array}$ & $\begin{array}{l}\text { Nitro- } \\
\text { gen, } \\
\text { organic, } \\
\text { dis- } \\
\text { solved } \\
\text { (mg/L } \\
\text { as } \mathrm{N} \text { ) }\end{array}$ & $\begin{array}{l}\text { Nitro- } \\
\text { gen, } \\
\text { ammonia, } \\
\text { dis- } \\
\text { solved } \\
\text { (mg/L } \\
\text { as } \mathrm{N})\end{array}$ & $\begin{array}{c}\text { Nitro- } \\
\text { gen, } \\
\mathrm{NO}_{2}+\mathrm{NO}_{3} \text {, } \\
\text { dis- } \\
\text { solved } \\
(\mathrm{mg} / \mathrm{L} \\
\text { as } \mathrm{N})\end{array}$ & $\begin{array}{l}\text { Phos- } \\
\text { phorus, } \\
\text { ortho, } \\
\text { dis- } \\
\text { solved } \\
\text { (mg/L } \\
\text { as } \mathrm{P} \text { ) }\end{array}$ \\
\hline $\begin{array}{l}\text { Cheyenne-I } \\
\text { (suction lysimeter) }\end{array}$ & 113 & $\begin{array}{r}5-13-88 \\
6-02-88 \\
6-08-88 \\
7-13-88 \\
8-09-88 \\
9-12-88 \\
10-14-88 \\
1-27-89 \\
3-06-89 \\
4-10-89 \\
7-08-89 \\
8-23-89 \\
1-11-90\end{array}$ & $\begin{array}{l}-- \\
-- \\
-- \\
25.0 \\
25.0 \\
30.0 \\
26.0 \\
26.0 \\
22.0 \\
19.0 \\
-- \\
24.5 \\
24.5\end{array}$ & $\begin{array}{r}-- \\
-- \\
-- \\
3,100 \\
3,100 \\
3,200 \\
2,800 \\
2,750 \\
2,600 \\
2,300 \\
-- \\
2,200 \\
1,990\end{array}$ & $\begin{array}{l}-- \\
-- \\
-- \\
-- \\
-- \\
-- \\
-- \\
-- \\
-- \\
-- \\
-- \\
-- \\
--\end{array}$ & $\begin{array}{r}-. \\
0.35 \\
.40 \\
.42 \\
.22 \\
.35 \\
-. \\
.54 \\
.53 \\
.34 \\
2.7 \\
.43 \\
--\end{array}$ & $\begin{array}{r}0.02 \\
.05 \\
.10 \\
.08 \\
.08 \\
.05 \\
.07 \\
.16 \\
.07 \\
.06 \\
.06 \\
.07\end{array}$ & $\begin{array}{r}0.71 \\
.10 \\
<.10 \\
<.10 \\
.12 \\
.35 \\
.95 \\
.66 \\
1.5 \\
1.5 \\
1.1 \\
1.1 \\
--\end{array}$ & $\begin{array}{l}-- \\
-- \\
-- \\
-- \\
-- \\
-- \\
-- \\
-- \\
-- \\
-- \\
-- \\
-- \\
--\end{array}$ \\
\hline $\begin{array}{l}\text { Cheyenne-I } \\
\text { (soil core) }\end{array}$ & 124 & $4-09-88$ & -- & -- & -- & 0.19 & 0.11 & 2.3 & 0.02 \\
\hline
\end{tabular}


Table 14. Chemical analyses of ground water from selected residential study sites and multiple-well monitoring sites--Continued

\begin{tabular}{|c|c|c|c|c|c|c|c|c|c|c|}
\hline $\begin{array}{l}\text { Site name } \\
\text { (source of } \\
\text { sample) }\end{array}$ & $\begin{array}{l}\text { Depth } \\
(\mathrm{ft})\end{array}$ & $\begin{array}{c}\text { Carbon, } \\
\text { organic, } \\
\text { total } \\
(\mathrm{mg} / \mathrm{L} \\
\text { as } \mathrm{C}) \\
\end{array}$ & $\begin{array}{c}\text { Cal- } \\
\text { cium, } \\
\text { dis- } \\
\text { solved } \\
(\mathrm{mg} / \mathrm{L}) \\
\end{array}$ & $\begin{array}{l}\text { Magne- } \\
\text { sium, } \\
\text { dis- } \\
\text { solved } \\
(\mathrm{mg} / \mathrm{L}) \\
\end{array}$ & $\begin{array}{l}\text { Sodium, } \\
\text { dis- } \\
\text { solved } \\
(\mathrm{mg} / \mathrm{L})\end{array}$ & $\begin{array}{c}\text { Potas- } \\
\text { sium, } \\
\text { dis- } \\
\text { solved } \\
(\mathrm{mg} / \mathrm{L}) \\
\end{array}$ & $\begin{array}{c}\text { Chlo- } \\
\text { ride, } \\
\text { dis- } \\
\text { solved } \\
(\mathrm{mg} / \mathrm{L})\end{array}$ & $\begin{array}{c}\text { Sulfate } \\
\text { dis- } \\
\text { solved } \\
(\mathrm{mg} / \mathrm{L} \\
\left.\text { as } \mathrm{SO}_{4}\right) \\
\end{array}$ & $\begin{array}{c}\text { Fluo- } \\
\text { ride, } \\
\text { dis- } \\
\text { solved } \\
(\mathrm{mg} / \mathrm{L})\end{array}$ & $\begin{array}{l}\text { Silica, } \\
\text { dis- } \\
\text { solved } \\
(\mathrm{mg} / \mathrm{L})\end{array}$ \\
\hline \multirow{13}{*}{$\begin{array}{l}\text { Cheyenne-I } \\
\text { (suction lysimeter) }\end{array}$} & \multirow{13}{*}{ r) 113} & -- & 54 & 51 & 270 & 7.9 & 660 & 360 & -- & 33 \\
\hline & & -- & -- & 60 & $\begin{array}{l}270 \\
320\end{array}$ & 8.2 & 820 & 370 & -- & 34 \\
\hline & & -- & -- & 67 & 320 & 8.4 & 820 & 380 & -- & 32 \\
\hline & & - & -- & -- & -- & -- & 830 & 380 & -- & 33 \\
\hline & & -- & -- & 62 & 320 & 7.3 & 780 & 370 & -- & 33 \\
\hline & & -- & -- & -- & -- & -- & 750 & 350 & -- & 32 \\
\hline & & -- & -- & -- & -- & -- & 690 & -- & -- & -- \\
\hline & & -- & -- & -- & -- & -- & 670 & 340 & -- & 33 \\
\hline & & -- & -- & -- & -- & -- & 570 & 320 & -- & 35 \\
\hline & & -- & -- & 41 & 270 & 6.6 & 110 & 310 & -- & 34 \\
\hline & & -- & -- & -- & \multirow{2}{*}{$24 \overline{0}$} & -- & -- & -- & -- & -- \\
\hline & & -- & -- & 36 & & 6.4 & 450 & 280 & -- & 33 \\
\hline & & -- & -- & -- & -- & -- & -- & -- & -- & -- \\
\hline $\begin{array}{l}\text { Cheyenne-I } \\
\text { (soil core) }\end{array}$ & 124 & -- & 82 & 21 & 110 & 5.4 & 150 & 180 & 1.1 & 31 \\
\hline $\begin{array}{l}\text { Site name } \\
\text { (source of } \\
\text { sample) }\end{array}$ & $\begin{array}{l}\text { Depth } \\
\text { (ft) }\end{array}$ & $\begin{array}{l}\text { Boron, } \\
\text { dis- } \\
\text { solved } \\
(\mu \mathrm{g} / \mathrm{L})\end{array}$ & $\begin{array}{c}\text { Iron, } \\
\text { dis- } \\
\text { solved } \\
(\mu \mathrm{g} / \mathrm{L})\end{array}$ & $\begin{array}{c}\text { Manga- } \\
\text { nese, } \\
\text { dis- } \\
\text { solved } \\
(\mu \mathrm{g} / \mathrm{L}) \\
\end{array}$ & \multicolumn{2}{|c|}{$\begin{array}{l}\text { Stron- } \\
\text { tium, } \\
\text { dis- } \\
\text { solved } \\
(\mu \mathrm{g} / \mathrm{L})\end{array}$} & $\begin{array}{l}\text { Zinc, } \\
\text { dis- } \\
\text { solved } \\
(\mu \mathrm{g} / \mathrm{L})\end{array}$ & $\begin{array}{l}\text { Lithium, } \\
\text { dis- } \\
\text { solved } \\
(\mu \mathrm{g} / \mathrm{L})\end{array}$ & $\begin{array}{c}{ }^{15} \mathrm{~N} /{ }^{14} \mathrm{~N} \\
\text { stable- } \\
\text { isotope } \\
\text { ratio } \\
\text { (permil) } \\
\end{array}$ & $\begin{array}{c}\text { Alka- } \\
\text { linity, } \\
\text { lab } \\
(\mathrm{mg} / \mathrm{L} \\
\text { as } \mathrm{CaCO}_{3}\end{array}$ \\
\hline \multirow{13}{*}{$\begin{array}{l}\text { Cheyenne-I } \\
\quad \text { (suction lysimeter) }\end{array}$} & 113 & 600 & -- & -- & \multicolumn{2}{|l|}{--} & -- & -- & -- & 103 \\
\hline & & 690 & -- & - & \multicolumn{2}{|l|}{-. } & -- & -- & -- & 97 \\
\hline & & 780 & -- & -- & \multirow{2}{*}{\multicolumn{2}{|c|}{-- }} & -- & -- & -- & 97 \\
\hline & & 740 & -- & -- & & & -- & -- & -- & 100 \\
\hline & & 770 & -- & -- & \multicolumn{2}{|l|}{.. } & -- & -- & -- & 92 \\
\hline & & 850 & -- & -- & \multicolumn{2}{|l|}{-. } & -- & -- & -- & 105 \\
\hline & & 880 & -- & -- & \multicolumn{2}{|l|}{-- } & -- & -- & -- & 113 \\
\hline & & 800 & -- & -. & -- & & -- & -- & -- & 113 \\
\hline & & 800 & -- & -- & -- & & -- & -- & -- & 121 \\
\hline & & 830 & -- & -- & -- & & -. & -- & -- & 122 \\
\hline & & -- & -- & -- & -- & & -- & -- & -- & -- \\
\hline & & 800 & -- & - & -- & & -- & -- & -- & 134 \\
\hline & & -- & -- & -- & -- & & -- & -- & -- & -- \\
\hline $\begin{array}{l}\text { Cheyenne-I } \\
\text { (soil core) }\end{array}$ & 124 & 460 & 240 & 340 & 1,000 & & 21 & 30 & -- & 115 \\
\hline
\end{tabular}


Table 14. Chemical analyses of ground water from selected residential study sites and multiple-well monitoring sites--Continued

\begin{tabular}{|c|c|c|c|c|c|c|c|c|c|c|}
\hline $\begin{array}{l}\text { Site name } \\
\text { (source of } \\
\text { sample) }\end{array}$ & $\begin{array}{c}\text { Depth } \\
\text { (ft) }\end{array}$ & Date & $\begin{array}{c}\text { Temper- } \\
\text { ature, } \\
\text { water } \\
\left({ }^{\circ} \mathrm{C}\right)\end{array}$ & $\begin{array}{l}\text { Speci } \\
\text { condu } \\
\text { anc } \\
(\mu \mathrm{S} / \mathrm{c}\end{array}$ & $\begin{array}{c}\mathrm{pH} \\
\text { (stan- } \\
\text { dard } \\
\text { units) }\end{array}$ & $\begin{array}{c}\text { Nitro- } \\
\text { gen, } \\
\text { organic } \\
\text { dis- } \\
\text { solved } \\
\text { (mg/L } \\
\text { as N) } \\
\end{array}$ & & & $\begin{array}{c}\text { Nitro- } \\
\text { gen, } \\
\mathrm{NO}_{2}+\mathrm{NO}_{3}, \\
\text { dis- } \\
\text { solved } \\
(\mathrm{mg} / \mathrm{L} \\
\text { as } \mathrm{N}) \\
\end{array}$ & $\begin{array}{l}\text { Phos- } \\
\text { phorus, } \\
\text { ortho, } \\
\text { dis- } \\
\text { solved } \\
\text { (mg/L } \\
\text { as } \mathrm{P} \text { ) }\end{array}$ \\
\hline $\begin{array}{l}\text { Choctaw } \\
\text { (suction lysimeter) }\end{array}$ & 131 & $\begin{array}{r}6-02-88 \\
6-08-88 \\
7-13-88 \\
8-08-88 \\
9-13-88 \\
10-14-88 \\
1-27-89 \\
3-06-89 \\
4-10-89 \\
7-08-89 \\
8-23-89 \\
1-11-90\end{array}$ & $\begin{array}{c}-- \\
-\ddot{24.0} \\
-- \\
27.0 \\
26.0 \\
20.0 \\
22.0 \\
21.0 \\
-- \\
22.0 \\
24.0\end{array}$ & $\begin{array}{l}. \\
1,12 \\
1,40 \\
1,15 \\
1,13 \\
1,17 \\
1,16 \\
1,05 \\
1,05 \\
1,04\end{array}$ & $\begin{array}{l}-- \\
-- \\
- \\
-- \\
-- \\
- \\
- \\
- \\
- \\
- \\
-\end{array}$ & $\begin{array}{c}0.58 \\
.47 \\
-- \\
.48 \\
-. \\
-- \\
.36 \\
.28 \\
.26 \\
.27 \\
.48 \\
.39\end{array}$ & & & $\begin{array}{c}0.47 \\
1.0 \\
.89 \\
.67 \\
.58 \\
.73 \\
.48 \\
.59 \\
.70 \\
.49 \\
.73 \\
.12\end{array}$ & $\begin{array}{l}-- \\
-- \\
-- \\
-- \\
-- \\
-- \\
-- \\
-- \\
-- \\
- \\
--\end{array}$ \\
\hline $\begin{array}{l}\text { Cheyenne-II } \\
\text { (neutron-access tube }\end{array}$ & 119 & $7-13-88$ & 25.0 & 1,00 & -- & 0.70 & & & -- & -- \\
\hline $\begin{array}{l}\text { Cajon } \\
\quad \text { (suction lysimeter) }\end{array}$ & 257 & $\begin{array}{l}2-06-89 \\
3-07-89 \\
4-12-89 \\
8-22-89 \\
1-11-90\end{array}$ & $\begin{array}{l}10.0 \\
20.0 \\
21.0 \\
22.0 \\
23.0\end{array}$ & $\begin{array}{r}66 \\
71 \\
1,50 \\
49 \\
51\end{array}$ & $\begin{array}{l}-- \\
-- \\
\overline{7} \\
--4\end{array}$ & $\begin{array}{c}0.75 \\
.20 \\
1.0 \\
.10 \\
-.\end{array}$ & 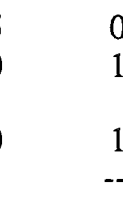 & & $\begin{array}{c}3.0 \\
3.1 \\
13 \\
1.1 \\
--\end{array}$ & $\begin{array}{l}-- \\
-- \\
- \\
- \\
-\end{array}$ \\
\hline $\begin{array}{l}\text { Site name } \\
\text { (source of } \\
\text { sample) }\end{array}$ & $\begin{array}{l}\text { Depth } \\
(\mathrm{ft})\end{array}$ & $\begin{array}{l}\text { Carbon, } \\
\text { organic, } \\
\text { total } \\
(\mathrm{mg} / \mathrm{L} \\
\text { as } \mathrm{C}) \\
\end{array}$ & $\begin{array}{l}\text { Cal- } \\
\text { cium, } \\
\text { dis- } \\
\text { solved } \\
(\mathrm{mg} / \mathrm{L}) \\
\end{array}$ & $\begin{array}{l}\text { Magne- } \\
\text { sium, } \\
\text { dis- } \\
\text { solved } \\
(\mathrm{mg} / \mathrm{L}) \\
\end{array}$ & $\begin{array}{l}\text { Sodium, } \\
\text { dis- } \\
\text { solved } \\
(\mathrm{mg} / \mathrm{L})\end{array}$ & $\begin{array}{l}\text { Potas- } \\
\text { sium, } \\
\text { dis- } \\
\text { solved } \\
(\mathrm{mg} / \mathrm{L}) \\
\end{array}$ & $\begin{array}{l}\text { Chlo- } \\
\text { ride, } \\
\text { dis- } \\
\text { solved } \\
(\mathrm{mg} / \mathrm{L}) \\
\end{array}$ & $\begin{array}{c}\text { Sulfate, } \\
\text { dis- } \\
\text { solved } \\
(\mathrm{mg} / \mathrm{L} \\
\left.\text { as } \mathrm{SO}_{4}\right) \\
\end{array}$ & $\begin{array}{c}\text { Fluo- } \\
\text { ride, } \\
\text { dis- } \\
\text { solved } \\
(\mathrm{mg} / \mathrm{L}) \\
\end{array}$ & $\begin{array}{c}\text { Silica, } \\
\text { dis- } \\
\text { solved } \\
(\mathrm{mg} / \mathrm{L})\end{array}$ \\
\hline $\begin{array}{l}\text { Choctaw } \\
\text { (suction lysimeter) }\end{array}$ & 131 & $\begin{array}{l}-- \\
-- \\
-- \\
- \\
-- \\
-- \\
-- \\
-- \\
-- \\
-- \\
- \\
--\end{array}$ & $\begin{array}{l}90 \\
75 \\
92 \\
89 \\
91 \\
-- \\
-- \\
-- \\
94 \\
89 \\
91 \\
--\end{array}$ & $\begin{array}{l}20 \\
20 \\
20 \\
20 \\
21 \\
-- \\
-- \\
-- \\
21 \\
19 \\
19 \\
--\end{array}$ & $\begin{array}{r}110 \\
110 \\
110 \\
110 \\
110 \\
-- \\
-- \\
-- \\
120 \\
110 \\
110 \\
--\end{array}$ & $\begin{array}{l}4.1 \\
4.1 \\
3.6 \\
3.5 \\
3.4 \\
-- \\
-- \\
-- \\
3.6 \\
7.4 \\
3.7 \\
--\end{array}$ & $\begin{array}{l}190 \\
190 \\
180 \\
190 \\
190 \\
180 \\
190 \\
180 \\
190 \\
180 \\
190 \\
180\end{array}$ & $\begin{array}{r}200 \\
210 \\
210 \\
190 \\
200 \\
-- \\
210 \\
210 \\
200 \\
210 \\
200 \\
200\end{array}$ & $\begin{array}{l}-- \\
-- \\
-- \\
- \\
- \\
-- \\
-- \\
-- \\
-- \\
-- \\
- \\
--\end{array}$ & $\begin{array}{l}32 \\
33 \\
34 \\
33 \\
34 \\
-- \\
36 \\
38 \\
36 \\
34 \\
34 \\
35\end{array}$ \\
\hline $\begin{array}{l}\text { Cheyenne-II } \\
\text { (neutron-access tube }\end{array}$ & 119 & -- & -- & -- & -- & -- & -- & -- & -- & -- \\
\hline $\begin{array}{l}\text { Cajon } \\
\text { (suction lysimeter) }\end{array}$ & 257 & $\begin{array}{l}-- \\
-- \\
-- \\
-- \\
15\end{array}$ & $\begin{array}{l}-- \\
-- \\
-- \\
-- \\
--\end{array}$ & $\begin{array}{l}-- \\
-- \\
-- \\
-- \\
--\end{array}$ & $\begin{array}{l}-- \\
-- \\
-- \\
-- \\
--\end{array}$ & $\begin{array}{l}-- \\
-- \\
-- \\
-- \\
--\end{array}$ & $\begin{array}{r}130 \\
-- \\
380 \\
69 \\
--\end{array}$ & $\begin{array}{r}55 \\
51 \\
150 \\
39 \\
--\end{array}$ & $\begin{array}{l}-- \\
-- \\
-- \\
-- \\
--\end{array}$ & $\begin{array}{l}12 \\
16 \\
29 \\
14 \\
--\end{array}$ \\
\hline
\end{tabular}


Table 14. Chemical analyses of ground water from selected residential study sites and multiple-well monitoring sites--Continued

\begin{tabular}{|c|c|c|c|c|c|c|c|c|c|}
\hline $\begin{array}{l}\text { Site name } \\
\text { (source of } \\
\text { sample) }\end{array}$ & $\begin{array}{l}\text { Depth } \\
\text { (ft) }\end{array}$ & $\begin{array}{l}\text { Boron, } \\
\text { dis- } \\
\text { solved } \\
(\mu \mathrm{g} / \mathrm{L})\end{array}$ & $\begin{array}{l}\text { Iron, } \\
\text { dis- } \\
\text { solved } \\
(\mu \mathrm{g} / \mathrm{L})\end{array}$ & $\begin{array}{c}\text { Manga- } \\
\text { nese, } \\
\text { dis- } \\
\text { solved } \\
(\mu \mathrm{g} / \mathrm{L})\end{array}$ & $\begin{array}{l}\text { Stron- } \\
\text { tium, } \\
\text { dis- } \\
\text { solved } \\
(\mu \mathrm{g} / \mathrm{L}) \\
\end{array}$ & $\begin{array}{l}\text { Zinc, } \\
\text { dis- } \\
\text { solved } \\
(\mu \mathrm{g} / \mathrm{L})\end{array}$ & $\begin{array}{l}\text { Lithium, } \\
\text { dis- } \\
\text { solved } \\
(\mu \mathrm{g} / \mathrm{L})\end{array}$ & $\begin{array}{l}{ }^{15} \mathrm{~N} /{ }^{14} \mathrm{~N}, \\
\text { stable- } \\
\text { isotope } \\
\text { ratio } \\
\text { (permil) } \\
\end{array}$ & $\begin{array}{c}\text { Alka- } \\
\text { linity, } \\
\text { lab } \\
(\mathrm{mg} / \mathrm{L} \\
\text { as } \mathrm{CaCO}_{3}\end{array}$ \\
\hline \multirow{12}{*}{$\begin{array}{l}\text { Choctaw } \\
\text { (suction lysimeter) }\end{array}$} & \multirow[t]{12}{*}{131} & 470 & -- & -- & -- & -- & -- & -- & 86 \\
\hline & & 480 & -- & -- & -- & -- & -- & -- & 85 \\
\hline & & 470 & -. & -- & -- & -- & -. & -. & 274 \\
\hline & & 460 & -- & -- & -- & -- & -- & -- & 87 \\
\hline & & 500 & -- & -. & -- & -- & -. & -. & 86 \\
\hline & & 490 & -- & -- & -- & -- & -- & -- & 88 \\
\hline & & 460 & -. & -- & -- & -- & -- & -. & 88 \\
\hline & & 450 & -- & -- & -- & -- & -- & -- & 88 \\
\hline & & 490 & -- & -- & -- & -- & -- & -- & 87 \\
\hline & & 480 & -- & -- & -- & -- & -- & -- & 89 \\
\hline & & 450 & -- & -- & -- & -- & -- & -- & 86 \\
\hline & & 480 & -- & -- & -- & -- & -- & -- & 87 \\
\hline $\begin{array}{l}\text { Cheyenne-II } \\
\text { (neutron-access tube) }\end{array}$ & 119 & -- & -- & -- & 1,100 & 87,000 & 28 & -- & -- \\
\hline \multirow{5}{*}{$\begin{array}{l}\text { Cajon } \\
\text { (suction lysimeter) }\end{array}$} & \multirow[t]{5}{*}{257} & 60 & -- & -- & -- & -- & -- & -- & 63 \\
\hline & & 20 & -- & -. & -- & -- & -- & -- & 88 \\
\hline & & 190 & -- & -- & -- & -- & -- & -- & 89 \\
\hline & & 20 & -- & -. & -- & -- & -- & -- & 89 \\
\hline & & -- & -- & -- & -- & -- & -- & -- & -- \\
\hline $\begin{array}{l}\text { Site name } \\
\text { (source of } \\
\text { sample) }\end{array}$ & $\begin{array}{l}\text { Depth } \\
\text { (ft) }\end{array}$ & Date & $\begin{array}{l}\text { Temper- } \\
\text { ature, } \\
\text { water } \\
\left({ }^{\circ} \mathrm{C}\right)\end{array}$ & $\begin{array}{l}\text { Specific } \\
\text { conduct- } \\
\text { ance } \\
(\mu \mathrm{S} / \mathrm{cm})\end{array}$ & $\begin{array}{l}\mathrm{pH} \\
\text { (stan- } \\
\text { dard } \\
\text { units) }\end{array}$ & $\begin{array}{l}\text { Nitro- } \\
\text { gen, } \\
\text { organic, } \\
\text { dis- } \\
\text { solved } \\
\text { (mg/L } \\
\text { as } \mathrm{N})\end{array}$ & $\begin{array}{c}\text { Nitro- } \\
\text { gen, } \\
\text { ammonia, } \\
\text { dis- } \\
\text { solved } \\
(\mathrm{mg} / \mathrm{L} \\
\text { as } \mathrm{N})\end{array}$ & $\begin{array}{c}\text { Nitro- } \\
\text { gen, } \\
\mathrm{NO}_{2}+\mathrm{NO}_{3} \text {, } \\
\text { dis- } \\
\text { solved } \\
(\mathrm{mg} / \mathrm{L} \\
\text { as } \mathrm{N})\end{array}$ & $\begin{array}{c}\text { Phos- } \\
\text { phorus, } \\
\text { ortho, } \\
\text { dis- } \\
\text { solved } \\
\text { (mg/L } \\
\text { as P) } \\
\end{array}$ \\
\hline \multirow{10}{*}{$\begin{array}{l}\text { Apple Ranchos } \\
\text { (multiple-well } \\
\text { monitoring site) }\end{array}$} & \multirow[t]{3}{*}{240} & $6-03-88$ & 24.5 & 1,370 & 6.2 & 0.35 & 0.05 & 1.5 & $<0.01$ \\
\hline & & $4-12-89$ & 23.0 & 1,340 & -- & -- & .21 & 1.7 & $<.01$ \\
\hline & & $8-22-89$ & 23.0 & 1,410 & 7.8 & -- & .01 & 1.7 & .01 \\
\hline & \multirow[t]{3}{*}{199} & $6-02-88$ & 24.0 & 1,280 & - & .26 & .04 & 2.0 & $<.01$ \\
\hline & & $4-12-89$ & 23.0 & 1,360 & -- & .36 & .04 & 2.9 & $<.01$ \\
\hline & & $8-22-89$ & 22.5 & 1,240 & 7.7 & -- & $<.01$ & 4.1 & .01 \\
\hline & \multirow[t]{3}{*}{173} & $6-03-88$ & 24.5 & 1,180 & 5.8 & .29 & .01 & 1.1 & $<.01$ \\
\hline & & $4-12-89$ & 23.5 & 1,240 & -- & -- & .04 & 1.9 & .04 \\
\hline & & $8-23-89$ & 21.5 & 1,180 & 7.7 & -- & .03 & 2.7 & .03 \\
\hline & 152 & $6-03-88$ & 25.0 & 1,290 & - & .33 & .17 & $<.10$ & -- \\
\hline \multirow{6}{*}{$\begin{array}{l}\text { Rincon } \\
\quad \text { (multiple-well } \\
\text { monitoring site) }\end{array}$} & \multirow[t]{2}{*}{285} & $4-12-89$ & 22.5 & 530 & -- & -- & 0.010 & $<0.10$ & 0.02 \\
\hline & & 8-23-89 & 23.5 & 895 & 7.9 & -- & $<.010$ & .89 & .02 \\
\hline & \multirow[t]{2}{*}{233} & $4-12-89$ & 23.0 & 660 & - & 0.38 & .020 & $<.10$ & .29 \\
\hline & & $8-23-89$ & 23.0 & 720 & 8.0 & .29 & .010 & 1.0 & .03 \\
\hline & \multirow[t]{2}{*}{200} & $4-12-89$ & 23.0 & 930 & -- & -. & .030 & $<.10$ & .11 \\
\hline & & $8-23-89$ & 22.0 & 810 & 7.8 & .24 & .060 & .18 & .05 \\
\hline
\end{tabular}


Table 14. Chemical analyses of ground water from selected residential study sites and multiple-well monitoring sites--Continued

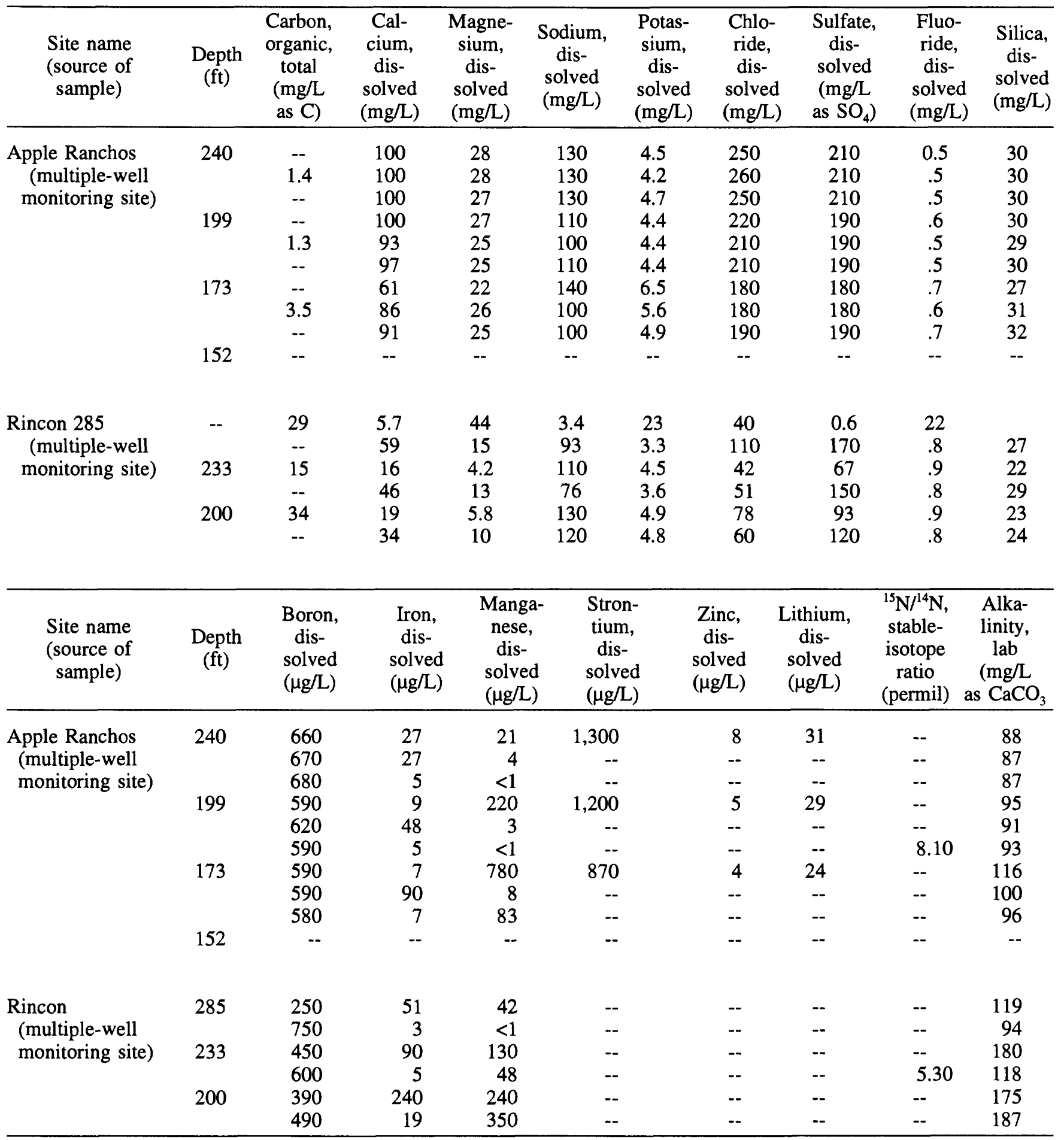




\section{MOVEMENT OF WASTEWATER THROUGH THE UNSATURATED ZONE}

In order to establish the effect of septic-tank wastewater on ground-water quality of the area, it was important to determine how fast wastewater is moving from seepage pits to the water table. It was thought that low nitrate concentrations in ground water throughout the area (table 1) indicated that wastewater from septic tanks installed during the 1970's and 1980 's (the period when most development occurred) had not yet reached the water table. In this study, the movement of the wastewater wetting front in the unsaturated zone was determined using moisturecontent profiles developed from analysis of soil cores, neutron logs, and suction-lysimeter data.

Several studies (Warrick and others, 1971; Ghuman and Prihar, 1980; and Young and others, 1992) have shown that wetting fronts move through the unsaturated zone at rates much faster than the solutes associated with the infiltrating water. Young and others (1992) theorized that the observed difference was caused by the displacement of pre-existing soil moisture by the applied water. They observed, in field experiments, that the difference between the arrival of the wetting front and the solute front was directly proportional to the water content of the unsaturated zone; larger differences (lags) were observed where the unsaturated zone had a higher preexisting water content. The rates of wastewater movement presented in this section of the report are representative of the wastewater wetting front; the movement of the actual wastewater will be slower.

\section{MOISTURE-CONTENT PROFILES}

Moisture content of the unsaturated zone was expected to be very low in areas unaffected by wastewater. A near-surface caliche layer present throughout most of the study area impedes percolation of the scant precipitation that occurs. This hypothesis was tested by selecting a new residence (Toltec) as the initial site to investigate. Field inspection of the soil cores collected at this site indicated that the unsaturated zone beneath the seepage pit indeed was very dry. Laboratory analyses indicate that nearly all the cores had moisture contents of less than about 5 percent, and about half had moisture contents of less than 2 percent (table 7). Therefore, the vertical extent of the wastewater wetting front can be deter- mined qualitatively by ascertaining whether soil cores beneath an active seepage pit are comparatively wet or dry. This distinction is made with relative ease at new sites, especially in upper parts of the unsaturated zone; however, it is less readily made in lower parts of the unsaturated zone, especially near the water table where moisture content would normally be higher even in the absence of any wastewater. In addition, the water table has declined by almost $50 \mathrm{ft}$ (fig. 7) in some areas, leaving a residual moisture in the unsaturated zone beneath the earlier water table. Distinguishing between wastewater-affected and natural (unaffected) soil zones soley on the basis of soil-moisture content is further complicated by the wide range in grain-size distributions that exists throughout the study area and with depth at individual sites.

Moisture-content profiles were prepared from analyses of soil cores collected between land surface and the water table at five sites (Cheyenne-I, Choctaw, Kiowa, Cheyenne-II, and Cajon) where seepage pits had been in operation for at least 2 years. The profiles are illustrated graphically in figure 13 presented later in this report. At all five sites, both field and laboratory determinations indicate that the entire unsaturated zone beneath the seepage pits was moist. Moisture contents in most soil cores exceeded 10 percent, except in cores containing predominantly sand and gravel (table 7). The presence of comparatively high moisture contents throughout the profiles suggests that the wastewater wetting front had reached the water table at all five selected sites. Chemical analyses of samples from the Cajon site collected after 1991 indicate, however, that wastewater had reached a depth of at least $199 \mathrm{ft}$, but it had not yet reached the water table, which was at least $260 \mathrm{ft}$ below land surface in 1991. Preliminary results from the resumption of water-quality monitoring after June 1993 at the Cheyenne-I site also suggest that wastewater may not yet have arrived at the three lowermost lysimeters (equal or deeper than $92.5 \mathrm{ft}$ ) in 1988 and (or) that these lysimeters are near or beneath a recently declining water table. A minimum value for the rate of vertical movement of the wastewater wetting front can be estimated at each site by dividing thickness of the unsaturated zone beneath the seepage pit by length of time that the seepage pit had been in service. These calculated minimum vertical flow rates of the wastewater wetting front, which are shown in the table that follows, served as this study's earliest estimates. 


\begin{tabular}{lccc}
\hline $\begin{array}{c}\text { Residential } \\
\text { study } \\
\text { site }\end{array}$ & $\begin{array}{c}\text { Thickness of } \\
\text { unsaturated } \\
\text { zone (ft) }\end{array}$ & $\begin{array}{c}\text { Age of septic tank } \\
\text { as of April 1988 } \\
\text { (years) }\end{array}$ & $\begin{array}{c}\text { Vertical } \\
\text { flow rate } \\
\text { (ft/d) }\end{array}$ \\
\hline Cheyenne-I & 87 & 5 & 0.05 \\
Choctaw & 99 & 10 & .03 \\
Kiowa & 125 & 9 & .04 \\
Cheyenne-II & 92 & 1.2 & .21 \\
Cajon & 213 & 10 & .06 \\
\hline
\end{tabular}

Rates determined later with greater precision, using methods that followed movement of the wastewater (neutron logs and lysimeter samples), confirmed that actual rates generally were greater.

The finding of wastewater (comparatively high moisture content) in soil cores collected from holes drilled about 5 to $7 \mathrm{ft}$ from the center of the seepage pit at established sites was the first indication in this study that there may be substantial lateral movement of wastewater as well as vertical movement. The extent of this lateral wastewater movement was further delineated by drilling an additional hole $25 \mathrm{ft}$ from the seepage pit at the Cheyenne-I site and $50 \mathrm{ft}$ from the seepage pit at the Choctaw site. Moisture content of soil cores from both holes was similar to moisture contents of cores from holes adjacent to the respective seepage pits (table 7). Water-quality analyses of soil cores from the Cheyenne-I lateral hole (table 7) and of one suction-lysimeter sample from the Choctaw site (table 10) also are similar to analyses from holes adjacent to the seepage pits. This confirms that wastewater can move laterally $50 \mathrm{ft}$ or more from seepage pits in some locations. Additional discussion of lateral movement based on wastewater discharge and constraints from mass-balance calculations at the Cajon site is given by Schroeder and others (1993).

Lateral flow can occur in the unsaturated zone wherever a coarse-textured layer of high permeability overlies a finer textured layer of low permeability. With continued infiltration, ponding (a perched water table) occurs just above the boundary of the impeding finer layer (Hillel, 1971, p. 143). Lateral flow also can take place where fine-textured soil overlies a layer of coarse-textured soil (Hillel, 1971, p. 143). Any discontinuities in texture can result in the development of preferential flow paths in the unsaturated zone (Steenhuis and others, 1991); the discontinuities, by implication, could be a major source of variability among water-quality data obtained from suction lysimeters. Finally, low-permeability caliche layers and other cemented layers also can cause lateral movement of wastewater.

\section{NEUTRON MOISTURE LOGS}

Moisture-content profiles were obtained from neutron moisture logs in order to more directly calculate rates of vertical movement of the wastewater wetting front. This approach involved collecting numerous neutron moisture logs from the three new sites (Toltec, Vasquez, and Little Beaver) and one established site (Cheyenne-II). Selected moisturecontent profiles that were obtained are shown in figure 12. Vertical movement of the wastewater wetting front is inferred from changes in successive moisture-content profiles. As previously stated, moisture content of the unsaturated zone is very low in areas unaffected by wastewater. Therefore, increasing moisture content in more recent profiles indicates vertical movement of the wastewater wetting front.

The vertical rate of movement of the wastewater wetting front is calculated by dividing the distance the wetting front has moved by the elapsed time (traveltime) between consecutive neutron moisture logs (table 15). Estimated rates range from $0.09 \mathrm{ft} / \mathrm{d}$ for the fine-grained consolidated soil between 48 and $67 \mathrm{ft}$ at Little Beaver to $0.79 \mathrm{ft} / \mathrm{d}$ for the coarsegrained unconsolidated soil between 35 and $59 \mathrm{ft}$ at Vasquez. In most cases, the estimated rates decrease with increasing depth. In fact, during the period of neutron moisture logging at Little Beaver, May 1988June 1989, little if any increase in moisture content was measured at depths below about $70 \mathrm{ft}$ (fig. 12C). Inspection of the geologic log for this site indicates that the soils are cemented (consolidated) from this depth to the bottom of the hole. The presence of these cemented soils would be expected to impede vertical movement of the wastewater.

As discussed previously, temporal changes in the moisture-content profiles indicate that vertical movement of the wastewater wetting front initially is transient. However, movement of the wastewater wetting front seems to approach steady-state conditions after the seepage pits have been used for some time, as indicated by very little change in successive moisture-content profiles. A steady-state condition is 


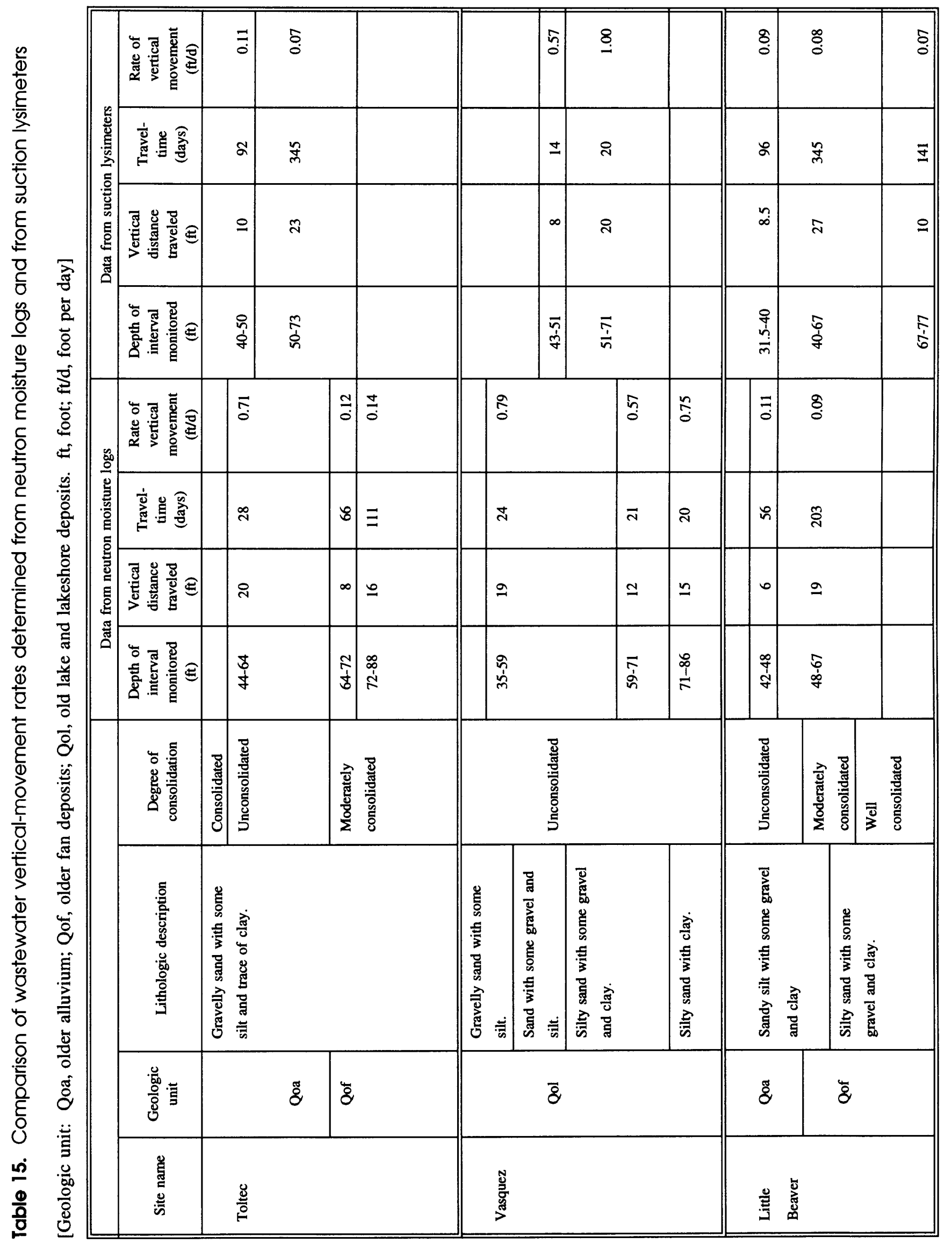




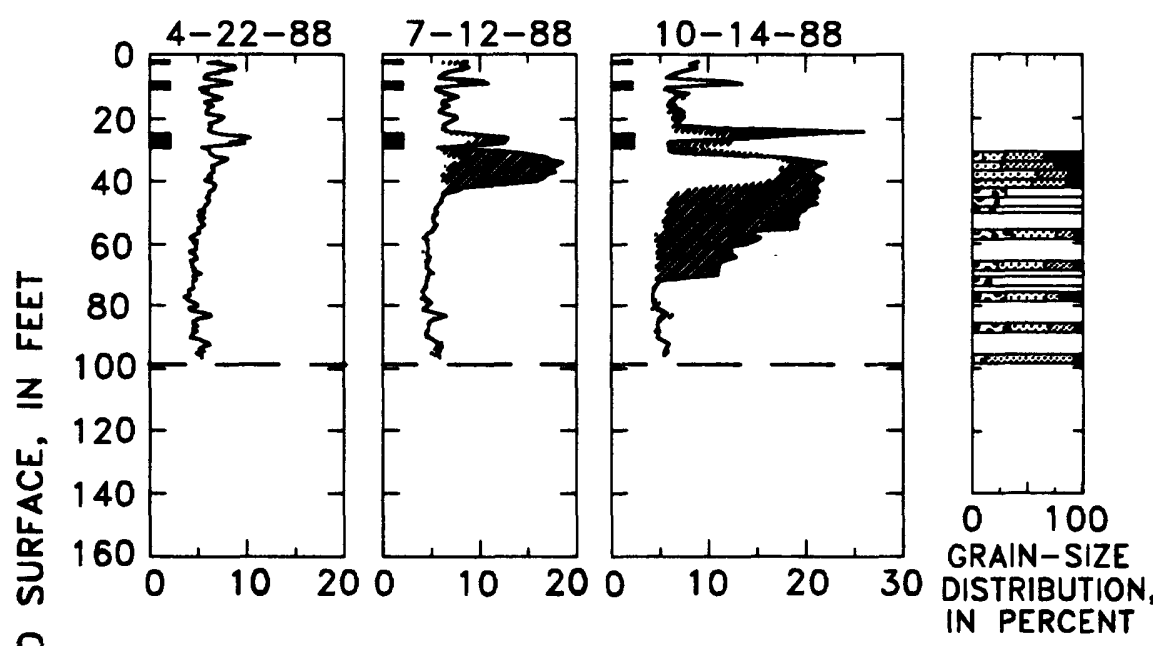

\section{EXPLANATION}

GRAIN SIZE-

Gravel

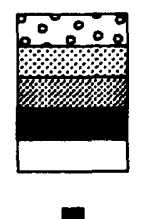

Coarse sand

Fine sand

Silt/Clay

Not determined

LOCATION OF

BENTONITE SEALS

6-8-89 DATE OF

MEASUREMENT

- BOTTOM OF

NEUTRON ACCESS

TUBE

NOTE:

Change in moisture content since previous measurement is indicated by shaded area
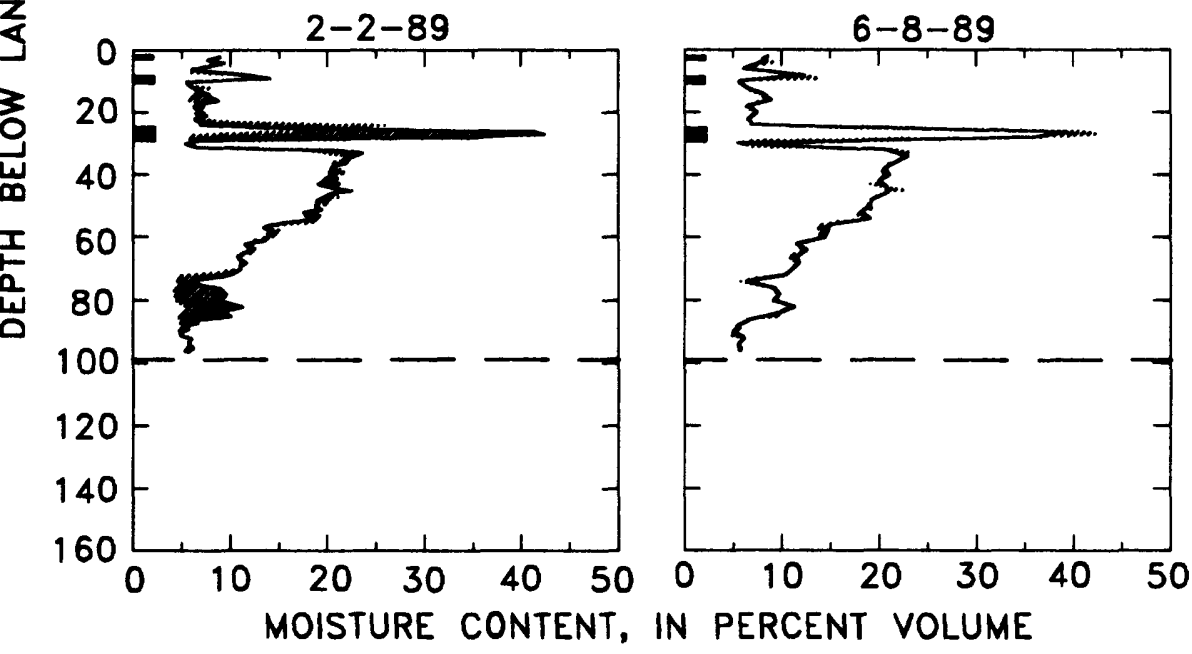

\section{(A) TOLTEC SITE}

Figure 12. Temporal changes in soil-moisture content and vertical variation in grain size at selected residential sites.

approached within the upper $80 \mathrm{ft}$ at all the recently occupied sites in less than 1 year (fig. 12). Moisturecontent profiles at the established site (Cheyenne-II) also reflect steady-state conditions. (Some changes in the Cheyenne-II profile are believed to be due to rewetting of the backfill that was placed around the neutron-access tube during its installation; this rewetting is most evident (fig. 12) at depths at which bentonite was used as a seal.) Steady-state conditions are established rapidly beneath seepage pits because wastewater discharge to the seepage pits remains nearly constant on a daily basis.

\section{SUCTION LYSIMETERS}

Sampling of suction lysimeters provides yet another estimate for the vertical rate of movement of the wastewater wetting front. The approach involved measurements from the periodic sampling for water quality in the suction lysimeters installed at multiple depths beneath the three recently constructed seepage pits (Toltec, Vasquez, and Little Beaver). Very little, if any, water could be extracted from the suction lysimeters prior to arrival of the wastewater wetting front. The vertical rate of movement of the waste- 

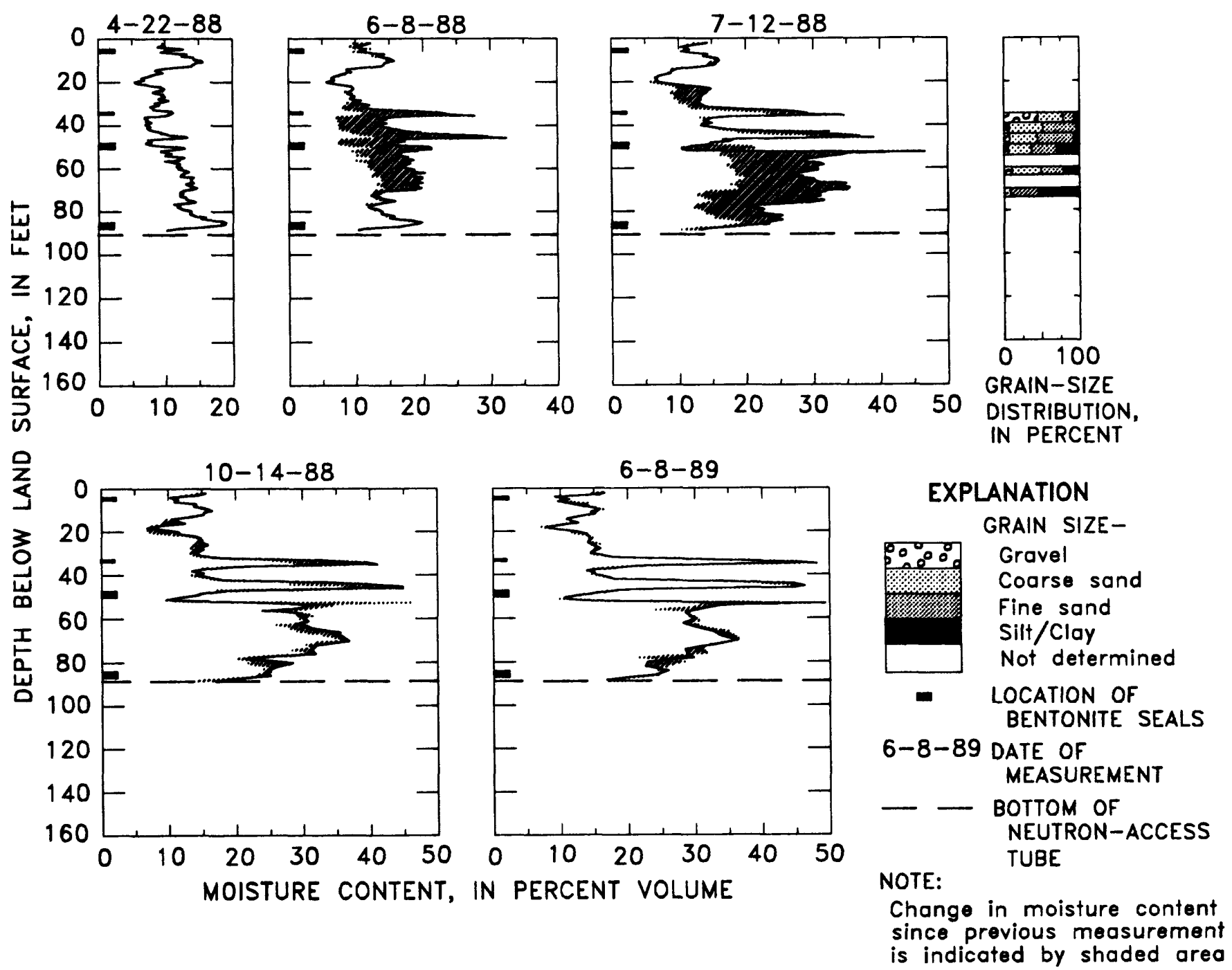

\section{(B) VASQUEZ SITE}

Figure 12.--Continued.

water wetting front is calculated by dividing the vertical distance between suction lysimeters at successive depths by the elapsed time between the first yield of water from suction lysimeters at successive depths. The estimated rates for the different sites are compared (table 15) with rates obtained from neutron moisture logs.

The vertical rate of movement of the wastewater wetting front estimated using the suction-lysimeter data ranged from 0.07 to $1.00 \mathrm{ft} / \mathrm{d}$; this range is similar to the range ( 0.09 to $0.79 \mathrm{ft} / \mathrm{d})$ estimated from neutron moisture logs (table 15). The lowest rate determined using either method is $0.07 \mathrm{ft} / \mathrm{d}$ for the unconsolidated, poorly sorted older alluvium and moderately consolidated older fan deposits at Toltec and the well-consolidated older fan deposits at Little Beaver. The highest rate is $1.0 \mathrm{ft} / \mathrm{d}$ for unconsolidated silty sand and gravel of the old lake and lakeshore deposits at Vasquez. If these are considered the minimum and maximum rates, respectively, for the movement of the wastewater wetting front in the 

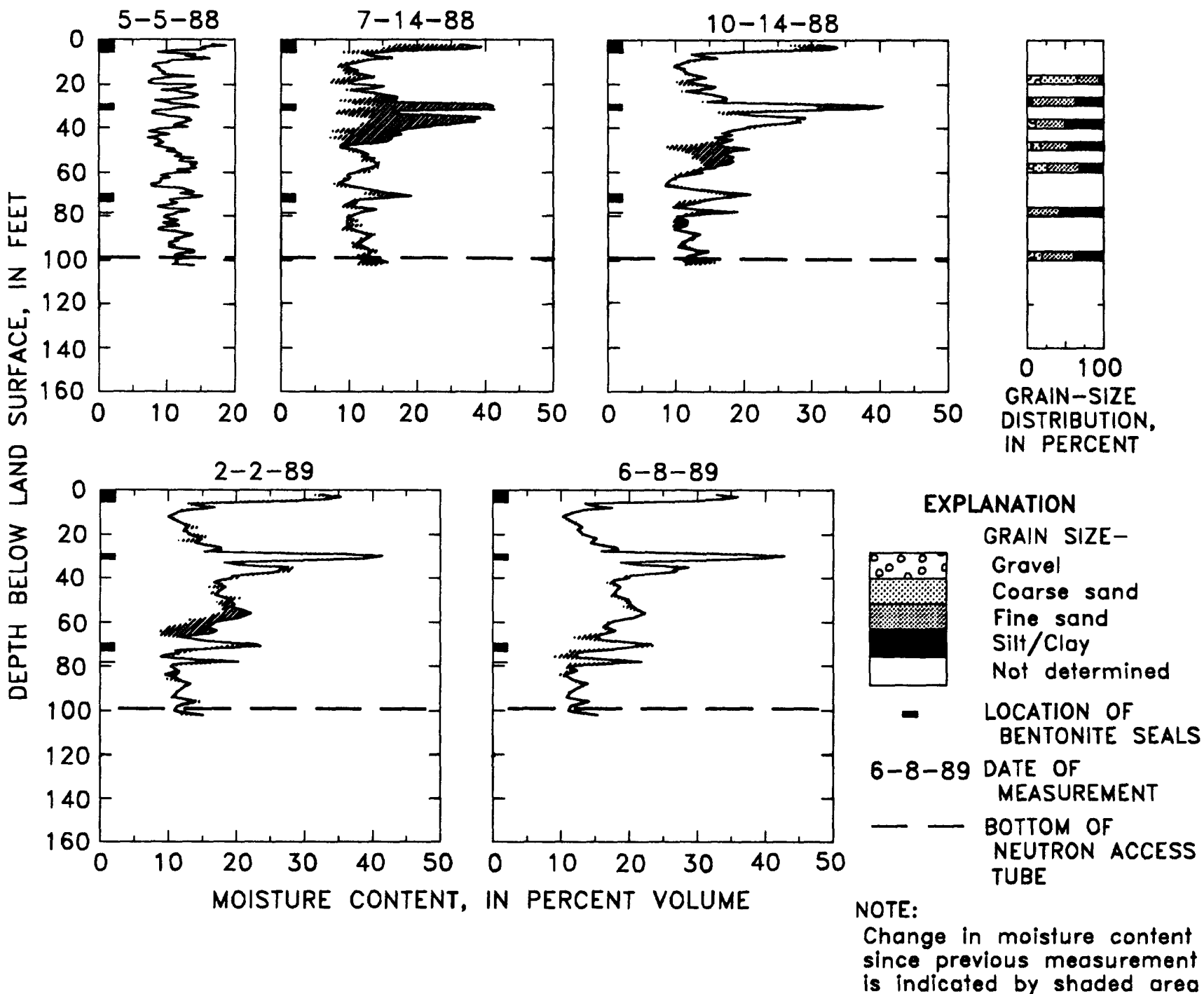

\section{(C) LITTLE BEAVER SITE}

Figure 12.--Continued.

study area, then the length of time for the wastewater wetting front to travel $150 \mathrm{ft}$ (the average depth to ground water in the study area) ranges from almost 6 months to almost 6 years. These results indicate that the wastewater wetting front from nearly all seepage pits constructed prior to the mid-1980's is likely to have reached the water table, where it is shallower than the average depth of $150 \mathrm{ft}$, by the end of this study in 1990.

In summary, moisture-content profiles, neutron moisture logs, and suction-lysimeter data all indicate that the wetting fronts resulting from wastewater discharge to seepage pits in the study area reach the underlying water table. Estimated rates for the movement of the wastewater wetting front range from a low of $0.03 \mathrm{ft} / \mathrm{d}$ (a minimum estimate based on profiles obtained from direct measurement of soilmoisture content) at the Choctaw site to a high of $1.0 \mathrm{ft} / \mathrm{d}$ (estimate based on suction-lysimeter method) at the Vasquez site. Actual vertical rates of wastewater (solute) movement probably are significantly less than these estimates. 

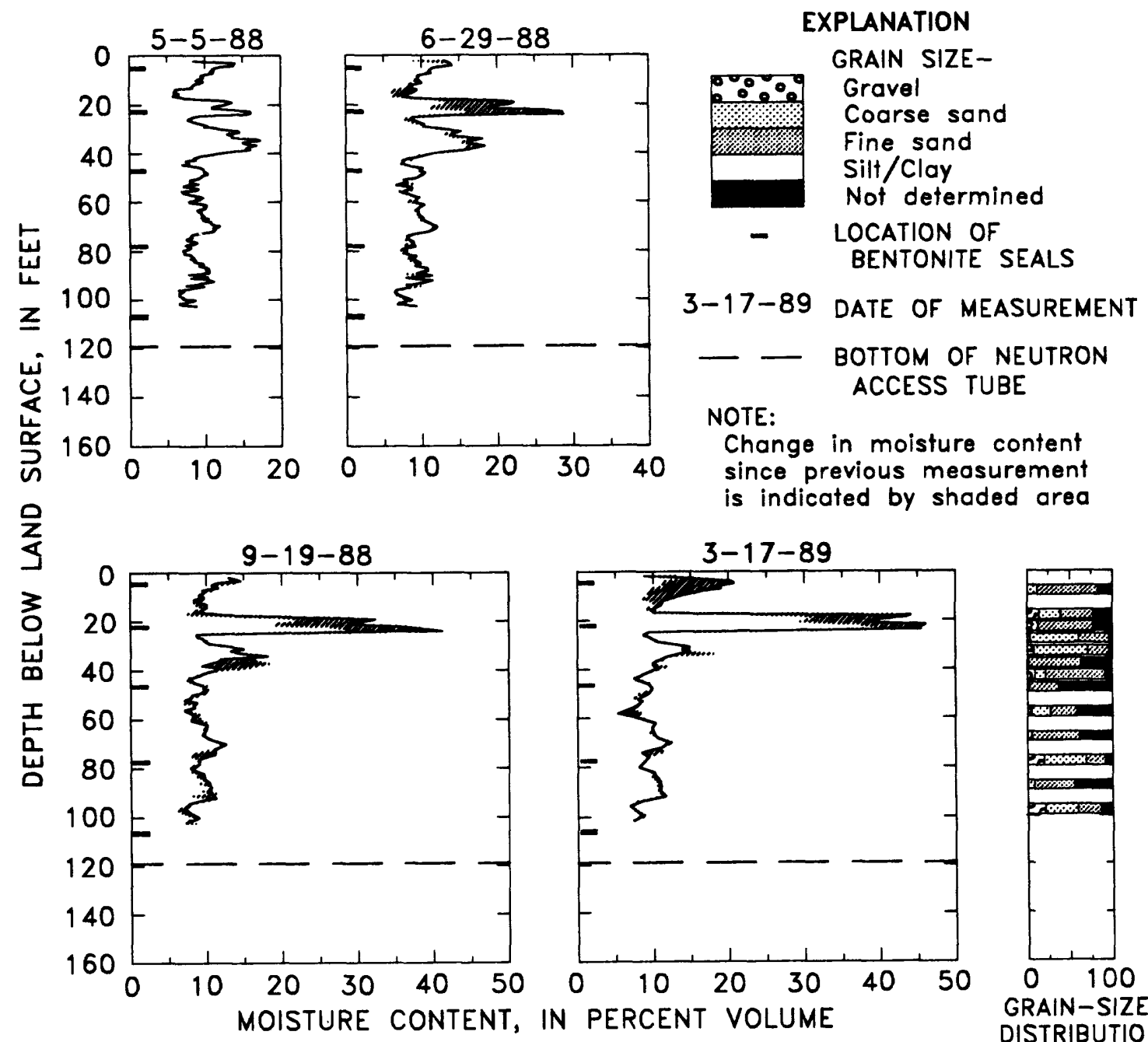

\section{(D) CHEYENNE-II SITE}

Figure 12.--Continued.

\section{CONCENTRATION OF SELECTED WASTEWATER CONSTITUENTS IN THE UNSATURATED ZONE}

Septic-tank wastewater is a major potential source of ground-water contamination in the study area. A septic tank separates floating and settleable solids (sludge) from wastewater while discharging the clarified wastewater into a drainfield or seepage pit. The sludge that accumulates at the bottom of the septic tank is decomposed by bacteria. The resulting wastewater contains high concentrations of nitrogen, bacteria, and organic carbon. As the wastewater moves through the unsaturated zone, the concentrations of these constituents-and thus the severity of ground-water contamination-can be greatly affected by physical, chemical, and biological processes. In this study, the concentration and changes in concentration of selected wastewater constituents (including nitrogen, total bacteria, fecal coliform, and selected organic compounds) were investigated as wastewater moved from the septic tank to the underlying water table at eight sites.

\section{NITROGEN}

Septic-tank wastewater is known to contain high concentrations ( 40 to $80 \mathrm{mg} / \mathrm{L}$ ) of nitrogen, (Bouwer, 1978, p. 413). As wastewater moves from the septic tank to a drainfield or seepage pit, and subsequently through the underlying unsaturated zone, both concentration and chemical form (speciation) of nitrogen in the wastewater change. The nitrogen 
species are interrelated by a complicated series of reactions that collectively constitute the nitrogen cycle. This section of the report includes a discussion of some of the more important reactions of the nitrogen cycle, changes in concentrations of the various nitrogen species as wastewater moves from the septic tank through the unsaturated zone, and possible reasons for the observed changes.

\section{NITROGEN CYCLE}

Because of the importance of nitrogen to the biological cycle, numerous researchers discuss the nitrogen cycle in great detail (Bartholomew and Clark, 1965; and National Research Council, 1978, for example). This section of this report emphasizes the processes of the nitrogen cycle that are important to an understanding of the accumulation of nitrogen and its transformation in wastewater as the wastewater moves from the septic tank through the unsaturated zone. The reader is referred to the references that are given above for a more detailed explanation of the complete nitrogen cycle.

Nitrogen in septic-tank wastewater is predominantly in the form of ammonia $\left(\mathrm{NH}_{3}\right)$ and organic nitrogen. (In this report, the term "ammonia" is used for the un-ionized form of ammonia $\left(\mathrm{NH}_{3}\right)$ and, collectively, for the cationic form $\left(\mathrm{NH}_{4}^{+}\right)$plus $\mathrm{NH}_{3}$ when there is no need or intention to distinguish between these forms. "Ammonium" is used specifically to indicate the cationic form.) Under aerobic (oxic) conditions, organic nitrogen in wastewater is converted to ammonia, which, along with ammonia already present in the wastewater, can be oxidized to nitrate $\left(\mathrm{NO}_{3}{ }^{-}\right)$. The conversion is a two-step biological process known as mineralization. The first step (conversion of organic nitrogen to ammonia) is referred to as ammonification and can be accomplished both by aerobic bacteria, which exist in the presence of oxygen, and anaerobic bacteria, which exist in the absence of oxygen. The second step (conversion of ammonia to nitrate) is referred to as nitrification and is carried out by several different groups of aerobic microorganisms. Nitrification also is a two-step process: the first group of bacteria, predominantly Nitrosomonas, oxidize ammonia to nitrite $\left(\mathrm{NO}_{2}{ }^{-}\right)$, and the second group, predominantly Nitrobacter, oxidize the nitrite to nitrate (National Research Council, 1978, p. 33). Nitrite usually does not accumulate during nitrification because it is oxidized as rapidly as it is formed.
Nitrogen can be removed from wastewater by sorption and ion exchange, ammonia volatilization, incorporation into cell biomass, plant-root uptake, and denitrification. As wastewater moves through the unsaturated zone, ammonium can be removed by adsorption (including ion exchange) onto soil particles. If the wastewater is sufficiently alkaline (that is, has high $\mathrm{pH}$ ), some ammonia may be lost to the atmosphere by volatilization of the gas. This process is more likely to occur in the seepage pit than in soil beneath the pit. Organic nitrogen may be immobilized in soils by adsorption and by incorporation into cell biomass as a result of biological activity. In most soil environments, nitrogen also is removed by plant-root uptake. In this study, however, plant-root uptake is not a significant factor because wastewater is discharged by seepage pits below the root zone.

The removal of nitrogen from wastewater in the study area apparently can be attributed, in part, to denitrification. Denitrification is the biochemical reduction of nitrate and nitrite to gaseous nitrogen in the form of molecular nitrogen and (or) nitrogen oxides. This process is carried out under anoxic conditions by many types of bacteria that can use the oxidized form of nitrogen as a terminal electron acceptor for respiration where oxygen has been depleted. Denitrification occurs rapidly and completely in soils in which conditions are anaerobic (anoxic) and organic matter is readily available (National Research Council, 1978, p. 44). Continual but slow loss of nitrogen also may occur in moist, fine-textured soils in which conditions generally are oxidizing but anoxic microenvironments are present (Broadbent and Clark, 1965).

\section{SEPTIC-TANK WASTEWATER}

The use of water within residences results in an increase in dissolved concentrations of nitrogen and many other chemical constituents in the wastewater. The magnitude of the increase was calculated by subtracting concentrations in tapwater from concentrations in wastewater sampled from the septic tank or seepage pit at six of the sites (table 16). The calculated differences show a rather large variability, particularly for some of the major ions and boron, among residences. For comparison, calculated differences between wastewater and tapwater concentrations from 3 years of monitoring at a rural residence near Fresno, California (Nightingale and McCormick, 1985), also are included in table 16. 
Table 16. Calculated increase (or decrease) in concentration of chemical constituents in water during household use. (Calculated by subtracting concentrations in tapwater (given in table 11) from concentrations in septic-tank wastewater (table 12))

[Wastewater concentrations used for Vasquez are seepage pit results for samples collected 6-8-88. Data from near Fresno are based on monitoring during 1977-80 at a rural residence occupied by two persons (Nightingale and McCormick, 1985). --, no data; $\mu \mathrm{S} / \mathrm{cm}$, microsiemen per centimeter at 25 degrees Celsius; $\mathrm{mg} / \mathrm{L}$, milligram per liter; $\mu \mathrm{g} / \mathrm{L}$, microgram per liter; $<$, less than value shown]

\begin{tabular}{|c|c|c|c|c|c|c|c|}
\hline \multirow{2}{*}{ Constituent } & \multicolumn{7}{|c|}{ Site } \\
\hline & Cheyenne-I & Vasquez & Choctaw & Kiowa & Cheyenne-II & Cajon & Fresno \\
\hline \multicolumn{8}{|l|}{ Specific conductance } \\
\hline$(\mu \mathrm{S} / \mathrm{cm}) \ldots \ldots$ & 910 & 494 & 523 & 243 & 1,174 & 528 & $354 \pm 10$ \\
\hline Nitrogen $(\mathrm{mg} / \mathrm{L})$. & ${ }^{1} 52$ & 33 & 46 & 21 & 49 & 62 & $15 \pm 1.5$ \\
\hline \multicolumn{8}{|l|}{ Orthophosphate-phosphorus } \\
\hline$(\mathrm{mg} / \mathrm{L}) \ldots \ldots \ldots \ldots$ & 7.2 & 18 & 1.2 & 4.9 & -- & -- & $6.0 \pm 0.5$ \\
\hline Organic carbon $(\mathrm{mg} / \mathrm{L})$ & -- & 17 & 42 & 10 & 40 & 63 & -- \\
\hline Calcium $(\mathrm{mg} / \mathrm{L}) \ldots \ldots \ldots$ & 2 & 13 & 13 & 8 & 23 & -- & $11 \pm 3$ \\
\hline Magnesium $(\mathrm{mg} / \mathrm{L}) \quad \ldots \ldots$ & 3 & 1.8 & 2.8 & 0 & 6 & -- & $2 \pm 1$ \\
\hline Sodium $(\mathrm{mg} / \mathrm{L}) \ldots$ & 125 & 54 & 40 & 17 & 158 & -. & $29 \pm 1$ \\
\hline Potassium $(\mathrm{mg} / \mathrm{L})$ & 10 & 10 & 13 & 4.9 & 9.9 & -- & $9 \pm 1$ \\
\hline Chloride $(\mathrm{mg} / \mathrm{L})$ & 80 & 31 & 31 & 9 & 62 & -- & $19 \pm 1$ \\
\hline Sulfate $(\mathrm{mg} / \mathrm{L})$ & 0 & 20 & 36 & -10 & 130 & -- & $5 \pm 2$ \\
\hline \multicolumn{8}{|l|}{ Alkalinity as calcium } \\
\hline carbonate $(\mathrm{mg} / \mathrm{L})$ & 373 & 162 & 198 & 97 & 408 & -. & $160 \pm 10$ \\
\hline Fluoride $(\mathrm{mg} / \mathrm{L}) \ldots$ & 0 & .2 & .2 & .1 & .2 & -- & -- \\
\hline Silica $(\mathrm{mg} / \mathrm{L}) \ldots$ & 4 & 10 & 6 & 3 & 16 & -- & $6 \pm 2$ \\
\hline Boron $(\mu \mathrm{g} / \mathrm{L})$ & 1,300 & 30 & 200 & -20 & 640 & -- & -- \\
\hline Iron $(\mu \mathrm{g} / \mathrm{L}) \ldots$ & 65 & 60 & 390 & 270 & 180 & -- & -- \\
\hline Manganese $(\mu \mathrm{g} / \mathrm{L})$ & 13 & 38 & 39 & 20 & 31 & -- & -- \\
\hline Strontium $(\mu \mathrm{g} / \mathrm{L})$ & -20 & 90 & 80 & 30 & 360 & -- & -- \\
\hline Zinc $(\mu \mathrm{g} / \mathrm{L}) \ldots$ & 8 & $<2$ & 50 & 20 & 17 & -. & -- \\
\hline Lithium $(\mu \mathrm{g} / \mathrm{L}) \quad \ldots \ldots \ldots$ & 14 & -4 & -2 & -3 & 6 & -- & -- \\
\hline
\end{tabular}

${ }^{1}$ Ammonia and organic nitrogen only.

The small range observed in the concentrations of nitrogen, for which the coefficient of variation is 10 percent, and other chemicals during a long period of monitoring at the Fresno residence suggests a relatively constant pattern of water usage among bath, kitchen, laundry, and toilet facilities. Some rather large site-to-site differences observed in this study are believed to be caused primarily by differences in the relative contribution from each of these household uses. For example, the large increase in boron in wastewater at Cheyenne-I and Cheyenne-II suggests greater use of laundry detergents (softeners) in these residences where the dissolved-solids and alkalineearth (hardness) concentrations of the tapwater are comparatively high.

For dissolved nitrogen, the chemical constituent of greatest interest in this study, site-to-site differences are much smaller than for other constituents (table 16). Increases in total-nitrogen concentrations range from $21 \mathrm{mg} / \mathrm{L}$ at Kiowa to $62 \mathrm{mg} / \mathrm{L}$ at Cajon (table 16). Because total nitrogen concentrations generally were less than $1 \mathrm{mg} / \mathrm{L}$ in the tapwater, the calculated increases are almost the same as the septictank wastewater concentrations, which ranged from 22 $\mathrm{mg} / \mathrm{L}$ at Kiowa to $63 \mathrm{mg} / \mathrm{L}$ at Cajon. For the five sites at which wastewater from the septic tank was sampled (Cheyenne-I, Choctaw, Kiowa, Cheyenne-II, and Cajon), dissolved-nitrogen concentrations average $47 \mathrm{mg} / \mathrm{L}$ (table 17).

Almost all the dissolved nitrogen in the septictank and seepage-pit wastewater was in the form of organic nitrogen and ammonia (tables 12 and 17), and little or no nitrate is present in any of the samples. These results are consistent with the absence of oxygen. In addition, methanethiol concentrations ranging from 2 to $11 \mu \mathrm{g} / \mathrm{L}$ were found in wastewater samples during analysis for purgeable (volatile) organic compounds. The presence of methanethiol, which implies not only absence of oxygen but also presence of hydrogen sulfide, indicates that the waste- 
Table 17. Median concentrations of selected constituents in tapwater, septic-tank, seepage-pit, and suction-lysimeter samples

[From data in table 11 (tapwater), table 12 (septic tank and seepage pit), and table 10 (suction lysimeters). ft, foot; $\mathrm{mg} / \mathrm{L}$, milligram per liter; $\mu \mathrm{S} / \mathrm{cm}$, microsiemen per centimeter at 25 degrees Celsius; <, less than reporting limit]

\begin{tabular}{|c|c|c|c|c|c|c|c|c|c|}
\hline $\begin{array}{l}\text { Source } \\
\text { of } \\
\text { sample }\end{array}$ & $\begin{array}{l}\text { Depth } \\
\text { of } \\
\text { lysim- } \\
\text { eter } \\
\text { (ft) }\end{array}$ & $\begin{array}{c}\text { Specific } \\
\text { conduct- } \\
\text { ance } \\
(\mu \mathrm{S} / \mathrm{cm})\end{array}$ & $\begin{array}{c}\text { Nitrogen, } \\
\mathrm{NO}_{2}+\mathrm{NO}_{3} \\
(\mathrm{mg} / \mathrm{L} \\
\text { as } \mathrm{N})\end{array}$ & $\begin{array}{c}\text { Nitrogen, } \\
\text { ammonia } \\
(\mathrm{mg} / \mathrm{L} \\
\text { as } \mathrm{N})\end{array}$ & $\begin{array}{c}\text { Nitrogen, } \\
\text { ammonia } \\
+ \text { organic } \\
\text { (mg/L } \\
\text { as } \mathrm{N})\end{array}$ & $\begin{array}{c}\text { Nitrogen, } \\
\text { organic } \\
\text { (mg/L } \\
\text { as } \mathrm{N} \text { ) }\end{array}$ & $\begin{array}{c}\text { Nitrogen, } \\
\text { (mg/L } \\
\text { as } \mathrm{N})\end{array}$ & $\begin{array}{l}\text { Chloride } \\
\text { (mg/L) }\end{array}$ & $\begin{array}{c}\text { Organic } \\
\text { carbon } \\
(\mathrm{mg} / \mathrm{L} \\
\text { as C) }\end{array}$ \\
\hline
\end{tabular}

Toltec site (new)

\begin{tabular}{lccccccccc}
\hline Tapwater & -- & 181 & 0.570 & $<0.010$ & $<0.20$ & $<0.20$ & 0.57 & 4.6 & -- \\
Septic tank & -- & -- & -- & -- & -- & -- & -- & -- & - \\
Seepage pit & -- & -- & -- & - & - & -- & - & - & - \\
Suction lysimeter & 33 & 692 & .280 & 5.85 & 12 & 6.2 & 12 & 23 & -- \\
& 40 & 702 & 8.00 & .030 & .90 & .87 & 8.9 & 20 & - \\
& 50 & 770 & 17.0 & .020 & 1.3 & 1.3 & 18 & 23 & -- \\
& 73 & 710 & 13.5 & .035 & 1.0 & .96 & 15 & 41 & -- \\
\hline
\end{tabular}

\begin{tabular}{|c|c|c|c|c|c|c|c|c|c|}
\hline \multicolumn{10}{|c|}{ Cheyenne-I site (established) } \\
\hline Tapwater & -- & 780 & 1.30 & $<0.010$ & $<0.20$ & $<0.20$ & 1.3 & 100 & -- \\
\hline Septic tank & -- & 1,690 & -- & -- & 53 & -- & 53 & 180 & -- \\
\hline Seepage pit & -- & -- & -- & -- & -- & -- & -- & -- & -- \\
\hline \multirow[t]{7}{*}{ Suction lysimeter } & 37 & 2,000 & 41.0 & .030 & 1.0 & .97 & 42 & 220 & 3.6 \\
\hline & 42 & 2,300 & 30.0 & .050 & 1.6 & 1.6 & 32 & 260 & 5.4 \\
\hline & 63 & 1,250 & 31.5 & .025 & .90 & .88 & 32 & 145 & 2.5 \\
\hline & 73 & 2,140 & 33.0 & .100 & 1.3 & 1.2 & 34 & 240 & 4.1 \\
\hline & 92.5 & 2,250 & 4.80 & .060 & 1.7 & 1.6 & 6.5 & -- & -- \\
\hline & 106 & 1,290 & 6.70 & .030 & 1.2 & 1.2 & 7.9 & 280 & 4.0 \\
\hline & ${ }^{1} 113$ & 2,300 & 1.10 & .070 & .60 & .53 & 1.7 & 510 & 6.9 \\
\hline \multicolumn{10}{|c|}{ Vasquez site (new) } \\
\hline Tapwater & -- & 202 & 1.10 & $<0.010$ & $<0.20$ & $<0.20$ & 1.1 & 7.7 & -- \\
\hline Septic tank & -- & -- & -- & -- & -- & -- & -- & -- & -- \\
\hline Seepage pit & -- & 822 & 3.9 & 28.5 & 24 & $<.10$ & 28 & 30 & 24.5 \\
\hline \multirow[t]{4}{*}{ Suction lysimeter } & 35 & 1,150 & 5.00 & .030 & .90 & .87 & 5.9 & 71 & -- \\
\hline & 43 & 1,030 & $<.100$ & 1.54 & .80 & .80 & .80 & 34 & -- \\
\hline & 51 & 900 & 6.40 & .015 & .60 & .58 & 7.0 & 36 & -- \\
\hline & 71 & 840 & 4.30 & .030 & .70 & .67 & 5.0 & 30 & -- \\
\hline
\end{tabular}

Choctaw site (established)

\begin{tabular}{lrrrrrrrrr}
\hline Tapwater & -- & 212 & 0.440 & 0.010 & $<0.20$ & $<0.20$ & 0.44 & 8.2 & -- \\
Septic tank & -- & 735 & .260 & 6.10 & 46 & 40 & 46 & 39 & 42 \\
Seepage pit & -- & -- & - & -- & -- & -- & -- & -- & - \\
Suction lysimeter & 33 & 1,550 & 6.40 & .050 & .80 & .75 & 7.2 & 88 & -- \\
& 48 & 1,560 & 11.5 & .050 & 1.3 & 1.2 & 13 & 110 & -- \\
& 80 & 1,010 & 20.5 & .040 & 1.4 & 1.4 & 22 & 70 & -- \\
& ${ }^{2} 131$ & 1,130 & .630 & .020 & .40 & .38 & 1.0 & 190 & --
\end{tabular}


Table 17. Median concentrations of selected constituents in tapwater, septic-tank, seepage-pit, and suction-lysimeter samples--Continued

\begin{tabular}{|c|c|c|c|c|c|c|c|c|c|}
\hline $\begin{array}{l}\text { Source } \\
\text { of } \\
\text { sample }\end{array}$ & $\begin{array}{l}\text { Depth } \\
\text { of } \\
\text { lysim- } \\
\text { eter } \\
\text { (ft) }\end{array}$ & $\begin{array}{c}\text { Specific } \\
\text { conduct- } \\
\text { ance } \\
(\mu \mathrm{S} / \mathrm{cm})\end{array}$ & $\begin{array}{c}\text { Nitrogen, } \\
\mathrm{NO}_{2}+\mathrm{NO}_{3} \\
(\mathrm{mg} / \mathrm{L} \\
\text { as } \mathrm{N})\end{array}$ & $\begin{array}{c}\text { Nitrogen, } \\
\text { ammonia } \\
\text { (mg/L } \\
\text { as } \mathrm{N})\end{array}$ & $\begin{array}{c}\text { Nitrogen, } \\
\text { ammonia } \\
\text { + organic } \\
\text { (mg/L } \\
\text { as } \mathrm{N} \text { ) }\end{array}$ & $\begin{array}{c}\text { Nitrogen, } \\
\text { organic } \\
(\mathrm{mg} / \mathrm{L} \\
\text { as } \mathrm{N})\end{array}$ & $\begin{array}{c}\text { Nitrogen, } \\
\text { (mg/L } \\
\text { as } \mathrm{N})\end{array}$ & $\begin{array}{c}\text { Chloride } \\
\text { (mg/L) }\end{array}$ & $\begin{array}{c}\text { Organic } \\
\text { carbon } \\
(\mathrm{mg} / \mathrm{L} \\
\text { as C) }\end{array}$ \\
\hline
\end{tabular}

Little Beaver site (new)

\begin{tabular}{lccccccccc}
\hline Tapwater & -- & 345 & 0.740 & $<0.010$ & $<0.20$ & $<0.20$ & 0.74 & 14 & -- \\
Septic tank & -- & -- & -- & -- & -- & - & -- & -- & - \\
Seepage pit & -- & -- & -- & - & -- & - & -- & -- & -- \\
Suction lysimeter & 31.5 & 2,500 & 20.0 & .070 & 1.1 & 1.0 & 21 & 89 & -- \\
& 40 & 1,100 & 4.60 & .030 & .45 & .42 & 5.0 & 80 & -- \\
& 67 & 980 & 20.0 & .030 & .70 & .67 & 21 & 81 & -- \\
& 77 & 2,600 & 20.0 & .220 & 3.6 & 3.4 & 24 & -- & --
\end{tabular}

\begin{tabular}{|c|c|c|c|c|c|c|c|c|c|}
\hline \multicolumn{10}{|c|}{ Kiowa site (established) } \\
\hline Tapwater & -- & 402 & 0.790 & $<0.010$ & $<0.20$ & $<0.20$ & 0.79 & 28 & -- \\
\hline Septic tank & -- & 645 & .20 & 18.0 & 22 & 4.0 & 22 & 37 & 10 \\
\hline Seepage pit & -- & -- & -- & -- & -- & - & -- & -- & -- \\
\hline Suction lysimeter & 32 & 1,290 & 9.60 & .030 & .75 & .72 & 10 & 78 & -- \\
\hline & 67.5 & 830 & 15.5 & .025 & .50 & .48 & 16 & 48 & -- \\
\hline & 107.5 & 1,220 & 15.5 & .085 & 1.8 & 1.7 & 17 & 66 & 8.3 \\
\hline & 149 & 825 & 1.30 & .040 & 1.3 & 1.3 & 2.6 & 83 & -- \\
\hline \multicolumn{10}{|c|}{ Cheyenne-II site (established) } \\
\hline Tapwater & -- & 736 & 1.20 & $<0.010$ & $<0.20$ & $<0.20$ & 1.2 & 98 & -- \\
\hline Septic tank & -- & 1,910 & 0 & 31.0 & 50 & 19 & 50 & 160 & 40 \\
\hline Seepage pit & -- & 1,890 & $<.100$ & 8.90 & 60 & 51 & 60 & 160 & 37 \\
\hline \multirow[t]{3}{*}{ Suction lysimeter } & 10 & -- & -- & -- & -- & -- & -- & -- & -- \\
\hline & 67 & 1,570 & 43.0 & .055 & 1.4 & 1.3 & 44 & 190 & -- \\
\hline & 98 & -- & -- & -- & -- & -- & -- & -- & -- \\
\hline \multicolumn{10}{|c|}{ Cajon site (established) } \\
\hline Tapwater & -- & 222 & 0.890 & 0.030 & $<0.20$ & $<0.20$ & 0.89 & 6.8 & .6 \\
\hline Septic tank & -- & 750 & - & 44.0 & 63 & 19 & ${ }^{3} 40$ & -- & 63 \\
\hline Seepage pit & -- & 747 & -- & 41.0 & 40 & $<.10$ & ${ }^{3} 63$ & -- & 43 \\
\hline \multirow[t]{8}{*}{ Suction lysimeter } & 35 & 1,040 & 31.0 & .055 & 1.7 & 1.6 & 33 & 68 & -- \\
\hline & 70 & 720 & 29.0 & .230 & 1.6 & 1.4 & 31 & 35 & 3.9 \\
\hline & 97.5 & 530 & 32.0 & .300 & 1.8 & 1.5 & 34 & 33 & 6.6 \\
\hline & 130 & 710 & 34. & .330 & 1.4 & 1.1 & 35 & 35 & 15 \\
\hline & 160 & 1,200 & 35.0 & .440 & 1.7 & 1.3 & 37 & -- & 7.6 \\
\hline & 199 & 580 & 15.0 & .105 & .70 & .60 & 16 & 50 & -- \\
\hline & 243 & 2,280 & 1.10 & .190 & 1.2 & 1.0 & 2.3 & 71 & 6.1 \\
\hline & ${ }^{2} 257$ & 660 & 3.05 & .875 & 1.4 & 2.2 & 4.4 & 130 & 15 \\
\hline
\end{tabular}

${ }^{1}$ Includes only analyses when water table was above suction lysimeter (11-27-89 to 1-11-90).

${ }^{2}$ Suction lysimeter was below water table.

${ }^{3} \mathrm{NO}_{2}+\mathrm{NO}_{3}$ not analyzed. Nitrogen assumed to be equal to ammonia + organic nitrogen. 
water is strongly reducing. Although wastewater samples were collected only once, the wide variation among sites in relative proportion of organic nitrogen and ammonia (tables 12 and 17) is consistent with rapid conversion of organic nitrogen to ammonia (ammonification) by bacteria (Canter and Knox, 1985, p. 75-76; and Khanbilvardi and Long, 1985).

\section{NITROGEN CONCENTRATIONS AND TRANSFORMATIONS}

This section of the report documents changes in nitrogen concentration and the transformation among different species of nitrogen as domestic wastewater moves from the septic tank through the underlying unsaturated zone. Nitrogen concentrations were determined in pore water (soil-core extracts) (table 7) and suction-lysimeter samples (table 10) collected at eight study sites to document the changes. The nitrate- $\mathrm{N}$ concentrations of soil-core extracts and suction-lysimeter samples collected at the eight study sites are shown graphically in figure 13. Also shown are grain-size distributions, soil-moisture content, chloride concentrations of soil-core extracts and suction-lysimeter samples, and numbers of nitratereducing bacteria present in soil cores for selected sites. Chloride concentrations are included because chloride is present in septic-tank wastewater and it is physically conservative and biologically unreactive, thereby making it a useful tracer of wastewater movement and transformations in the unsaturated zone. Median concentrations of the different nitrogen species found in the suction-lysimeter samples are given in table 17. Ideally, the last sample collected would be anticipated to be the most representative of actual concentrations in the unsaturated zone; however, median values are chosen instead to minimize any biases resulting from a single anomalous result or from failure of the earliest data to yet reflect steady-state conditions as noted previously in the "Pore-Water Quality" section.

As septic-tank effluent is discharged to a new seepage pit, it percolates readily through the base of the pit into the surrounding soil, leaving behind only a small quantity of wastewater in the seepage pit. However, after operation of the disposal system for a period of time, microbial activity in the anaerobic environment that prevails in the wastewater quickly results in biological clogging of the cinder blocks and soil immediately adjacent to the pit's wall (Stewart and others, 1979, and references therein). Progressive clogging causes the wastewater level to rise in the seepage pit until it reaches a zone of sufficiently high permeability that it can't be sealed by microbial activity, and most of the wastewater then percolates through the rapid-flow pathway at this level (Sinton, 1986). For the purposes of this study, this level is referred to as the active discharge level of the seepage pit. This active discharge level ranges from the bottom of the seepage pit at new residences such as Vasquez (about $35 \mathrm{ft}$ below land surface) to about 20 $\mathrm{ft}$ below land surface at the established sites. The unsaturated zone above the active discharge level is unaffected by septic-tank wastewater. This zone contains high concentrations of nitrate and chloride in soil moisture (table 7 and fig. 13) that probably are related to the caliche layer present in most of the study area. The high nitrate and chloride concentrations in this shallow zone are characteristic of shallow desert soils where soil-moisture content is very low and leaching is minimal.

With the exception of only a few samples collected directly beneath the seepage pits, dissolved nitrogen in the unsaturated zone is almost entirely in the form of nitrate (tables 7, 10, and 17). This indicates that reduced nitrogen (ammonia and organic nitrogen) present in the septic-tank wastewater is rapidly nitrified by microorganisms in soil near the seepage pit. Nitrification is an aerobic process that requires oxic conditions. Measured oxygen concentrations of about 19 volume percent (air is 21 percent) in soil gas from the unsaturated zone at Cheyenne-I and the general observation of brown coloration (as opposed to gray or olive coloration) of nearly all the cores recovered at all sites suggests that the unsaturated zone is well aerated. The main bacterial species responsible for nitrification (Nitrosomonas and Nitrobacter) were sought but were not detected in core samples (table 9), possibly because the reaction takes place in such a narrow zone that appropriate samples close enough to the seepage pit were not obtained.

Careful measurement of $\mathrm{pH}$ on selected core extracts provides additional indirect evidence for nitrification. The overall stoichiometric reaction represented by

$$
\mathrm{NH}_{4}^{+}+2 \mathrm{O}_{2} \rightarrow \mathrm{NO}_{3}^{-}+2 \mathrm{H}^{+}+\mathrm{H}_{2} \mathrm{O}
$$

indicates that nitrification is accompanied by the release of hydrogen ions (acidity). Accurate measurement of $\mathrm{pH}$ in the deionized-water extracts of core material was difficult to achieve because of poor buffering in the low-ionic-strength solutions, (voltage) drift of the electrode, and the potential for carbon dioxide exchange with the atmosphere. Improved reliability was obtained after deionized water equilibrated with atmospheric carbon dioxide ( $\mathrm{pH}=5.6-5.7)$ was used as a secondary 

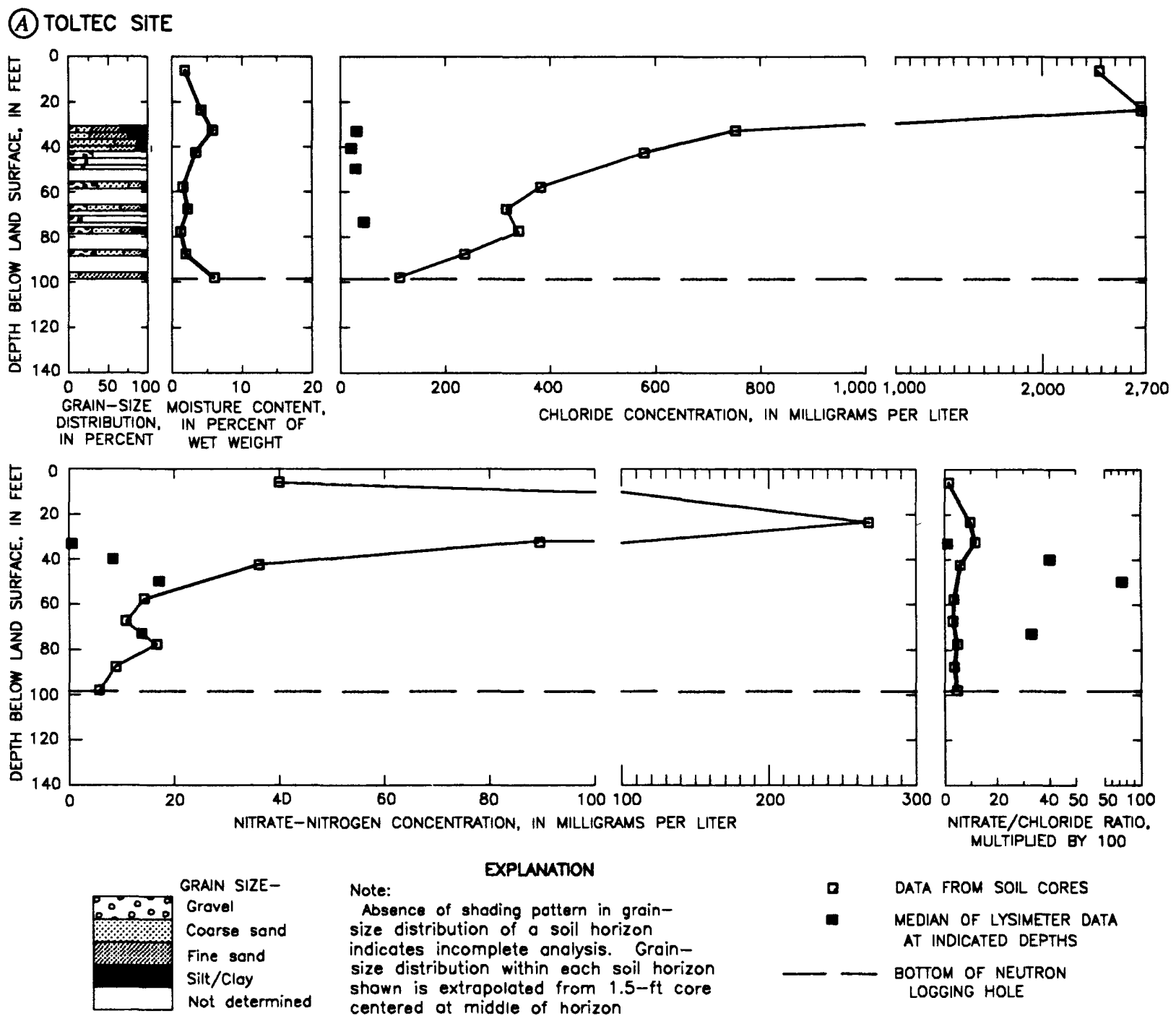

Figure 13. Vertical variation in selected physical properties and in concentrations of selected chemical and biological constituents at residential sites.

standard to calibrate the $\mathrm{pH}$ electrode. For the purpose of distinguishing those core extracts in which this more exacting procedure was followed, as opposed to those in which only commercial $\mathrm{pH}$ standards were used, the more reliable $\mathrm{pH}$ data are listed to hundredths, rather than tenths, in table 7 . Results show that $\mathrm{pH}$ in the extract from $13-15 \mathrm{ft}$ at Choctaw, 17-19 ft at Kiowa, and 27-29 $\mathrm{ft}$ at Cheyenne-II is about 1 unit less than average $\mathrm{pH}$ below these depths. The decrease in $\mathrm{pH}$ persists over only a narrow depth interval because of rapid neutralization by reaction with the soil. On the basis of estimated wastewater movement rates of 0.07 to $1 \mathrm{ft} / \mathrm{d}$ (from table 15), it is apparent that nitrification and subsequent neutralization of the acid generated must take no longer than a few weeks.
At all the sites, total-nitrogen concentrations were lower in samples from suction lysimeters emplaced beneath the seepage pit than in septic-tank wastewater (table 17). For the five established sites (Cheyenne-I, Choctaw, Kiowa, Cheyenne-II, and Cajon), the dissolved-nitrogen concentration for the suction lysimeters closest to the bottom of the seepage pit averaged $27 \mathrm{mg} / \mathrm{L}$, about 40 percent less than the average nitrogen concentration of $46 \mathrm{mg} / \mathrm{L}$ in wastewater (septic tank and seepage pit) at the same sites (table 17). Wastewater sampling was not sufficiently frequent and lysimeters were not spaced sufficiently close to permit a precise mass-balance estimate of nitrification extent. Studies elsewhere, however, suggest that virtually all the dissolved ammonia present in the septic-tank wastewater is 
(B) CHEYENNE-I SITE

(First lysimeter hole and lateral-hole core data)
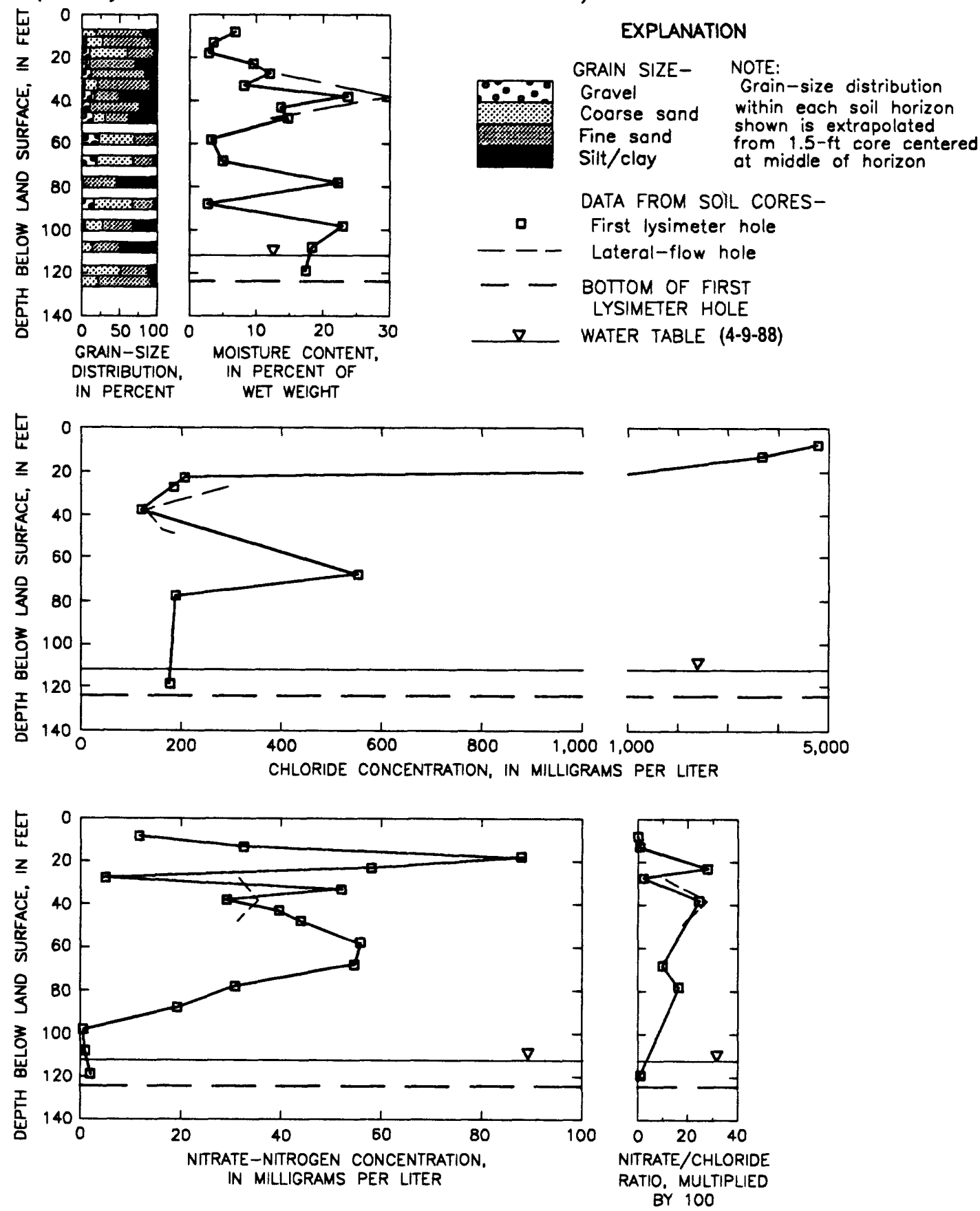

Figure. 13 Continued.

ultimately transformed to nitrate (Stewart and others, 1979, and references therein). For example, Walker and others $(1973 \mathrm{a}, \mathrm{b})$ found that the concentration of nitrate in a sandy drainfield below a biologically encrusted sublayer was approximately equal to that of total nitrogen in the septic-tank wastewater and, also, that the oxygen content of the soil gas was 19 percent, as in this study. In these other studies, septic-tank wastewater was discharged to drainfields, rather than into seepage pits. The results of this study suggest that significant nitrogen is removed in the seepage pit and (or) in the soil immediately adjacent 
(First and second lysimeter hole core data)

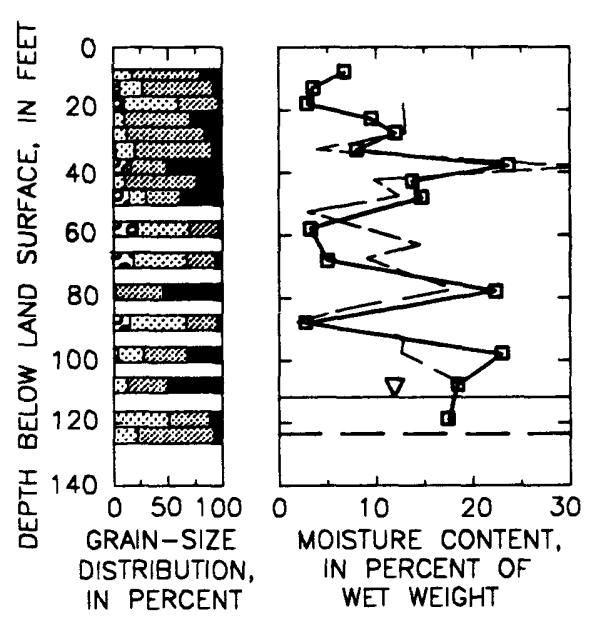

\section{EXPLANATION}

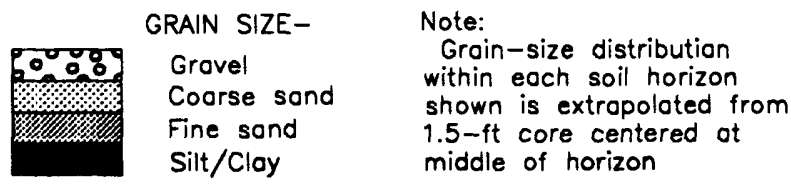

DATA FROM SOIL CORES-

$\longrightarrow$ First lysimeter hole

$\rightarrow \quad$ (MPN) Less thon bocterio detection limit

$\rightarrow$ - Second lysimeter hole

- MEDIAN OF LYSIMETER

DATA AT INDICATED

DEPTHS

- BOTTOM OF FIRST

$\nabla$ LYSIMETER HOLE DISTRIBUTION
IN PERCENT

WET WEIGHT

WATER TABLE (4-9-88)
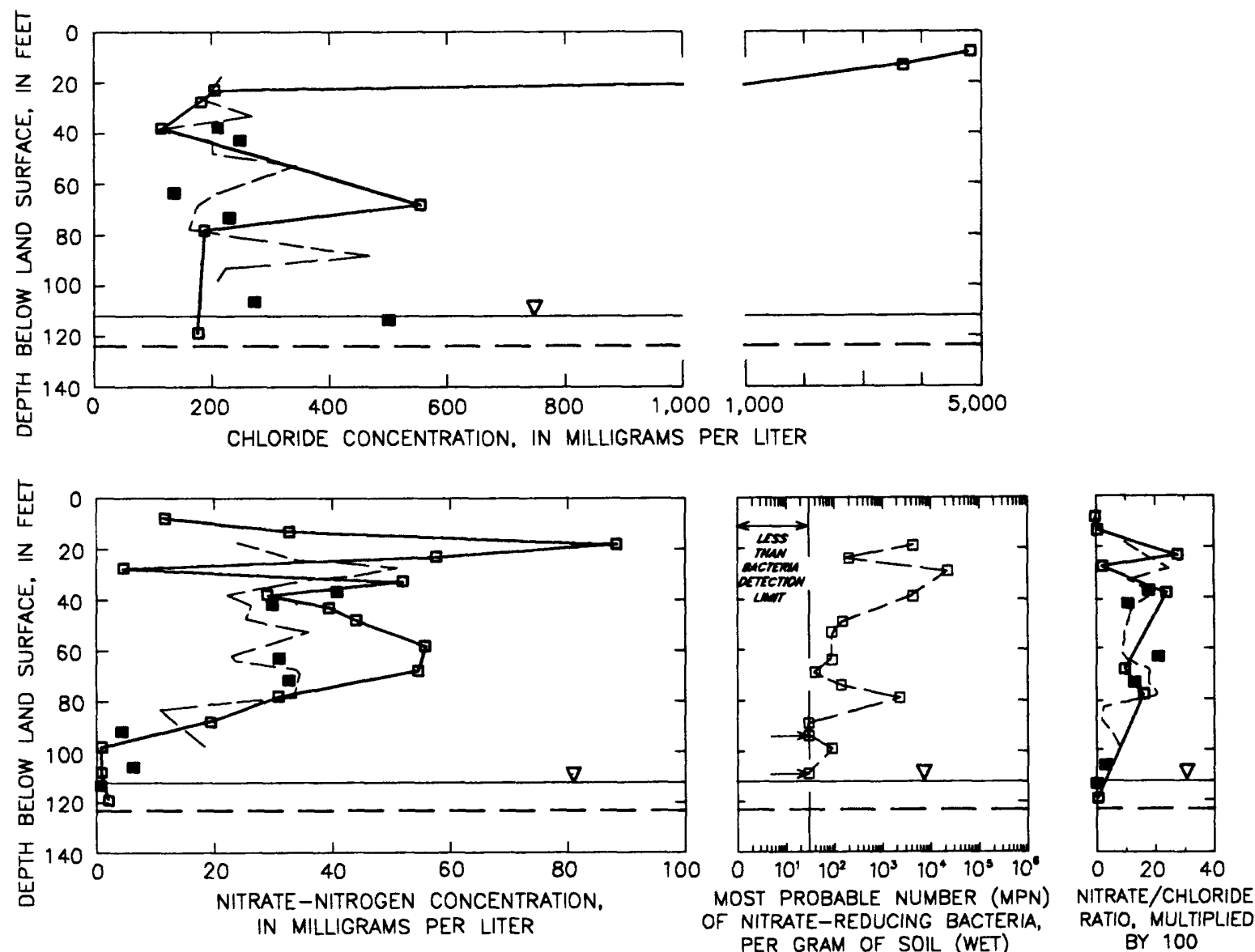

Figure 13. Continued.

to the seepage pit. Possible mechanisms for nitrogen reduction are partial denitrification, physical loss of nitrogen in the reduced form, volatilization of ammonia (from the seepage pit), incorporation in organic matter deposited on the walls and floor of the seepage pit, sorption of ammonium and organic nitrogen on the soil, and ion exchange of ammonium on clays. 
(D) Vasquez STIE
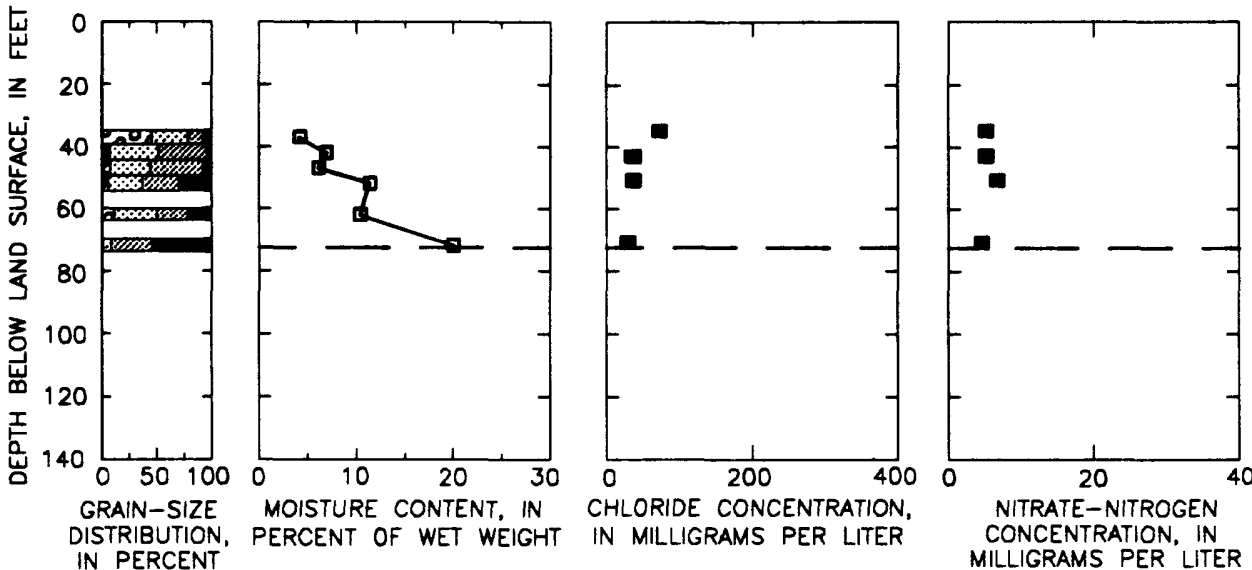

CHLORIDE CONCENTRATION,

CONCENTRATION, IN

MILLIGRAMS PER LITER

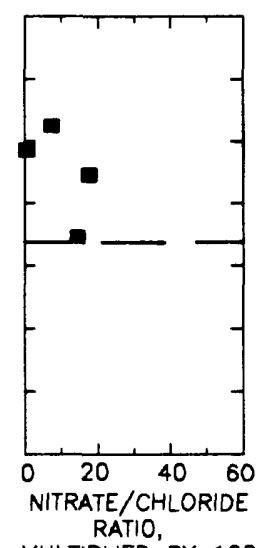

EXPLANATION

GRAIN SIZE-

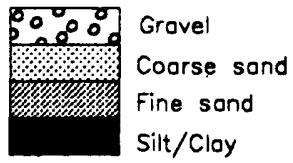

- DATA FROM SOIL CORES

- MEDIAN OF LYSIMETER DATA AT INDICATED DEPTHS

NOTE:

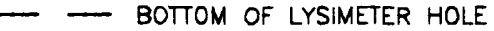

Groin-size distribution within eoch soil horizon shown is extrapoloted from $1.5-\mathrm{ft}$ core centered at middle of horizon

(E) CHOCTAW SITE
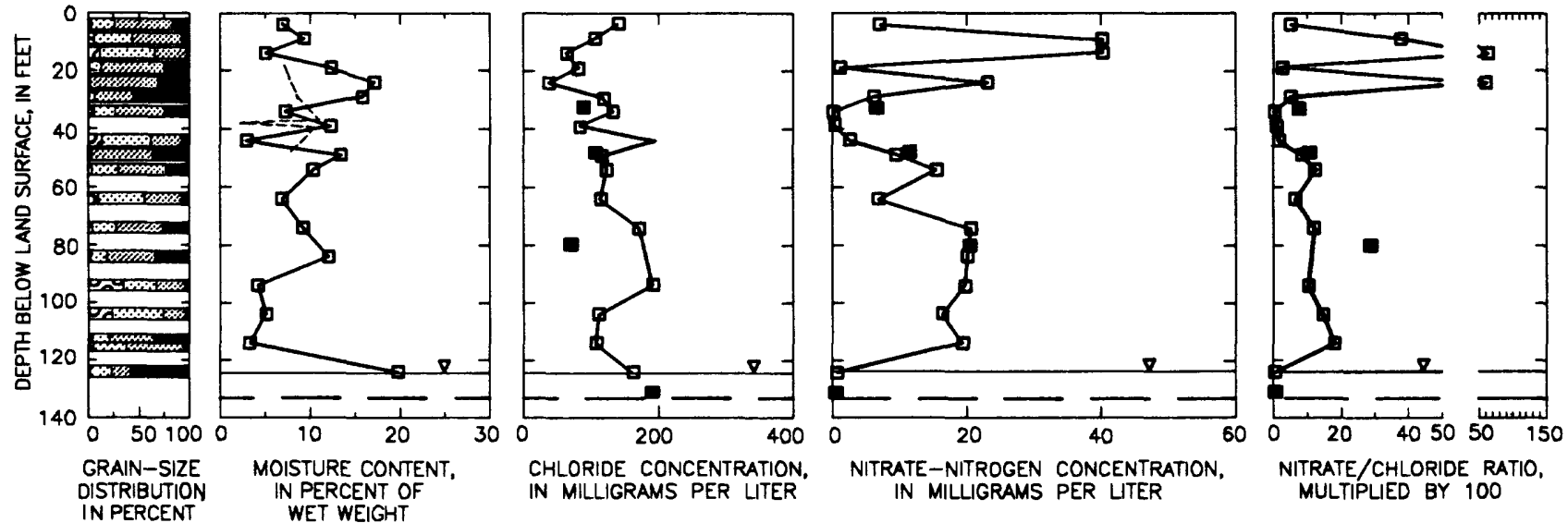

EXPLANATION

\begin{tabular}{|ll} 
GRAIN SIZE- & NOTE: \\
Grovel & Groin-size distribution within each \\
Coorse sand & soil horizon shown is extrapolated \\
Fine sand & from $1.5-\mathrm{ft}$ core centered at \\
Silt/Clay & middle of horizon
\end{tabular}

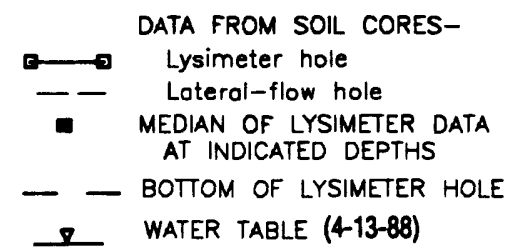

Figure 13. Continued.

As the septic-tank wastewater moves from the seepage pit through the unsaturated zone, nitrification seems to continue, at least for some depth, as indicated by some increase in nitrate concentration with increasing depth at most of the sites (tables 7 and 17, fig. 13). However, this trend is suddenly reversed above the water table at the Choctaw, Kiowa, and Cajon sites and opposite moist fine- 
(F) UTTLE BEAVER SITE
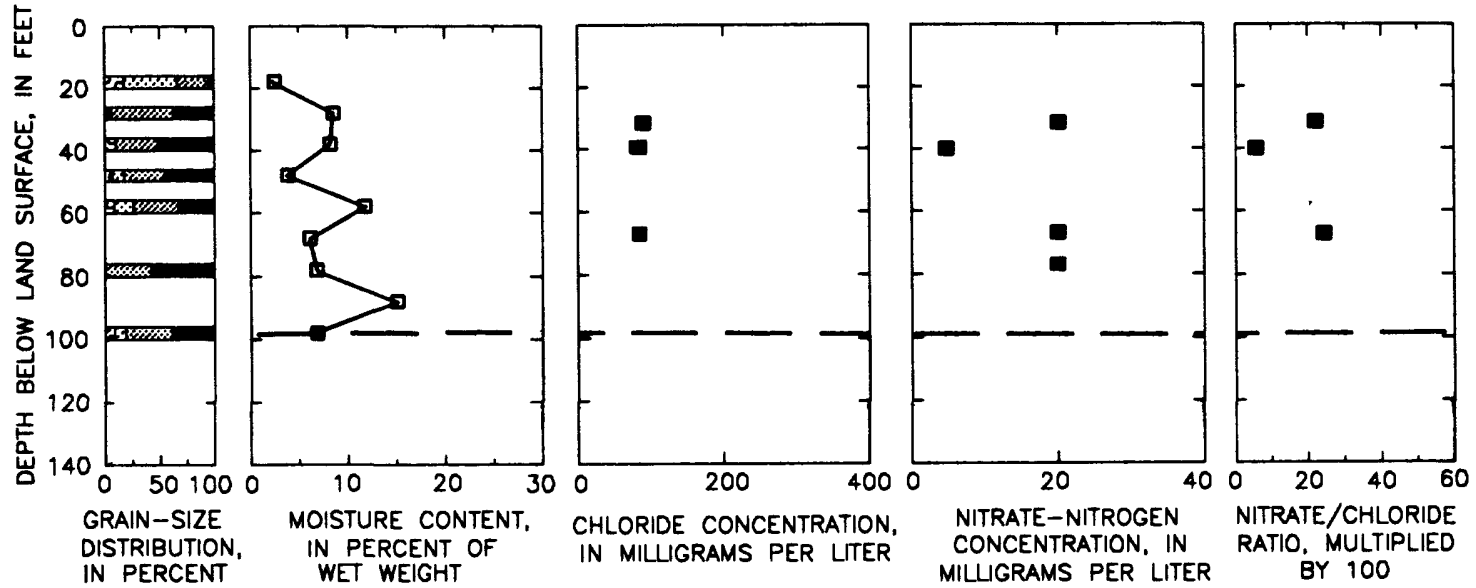

GRAIN SIZE-

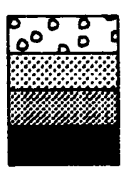

Gravel

Coarse sand

Fine sand

Silt/Clay

CHLORIDE CONCENTRATION

NITRATE-NITROGEN

CONCENTRATION, IN

MILLGRAMS PER LITER

RATIO, MULTIPLIED

BY 100

EXPLANATION

NOTE:

Grain-size distribution within each soil horizon shown is extrapolated from 1.5-ft core centered ot middle of horizon

- DATA FROM SOIL CORES

- MEDIAN OF LYSIMETER DATA AT INDICATED DEPTHS - BOTTOM OF NEUTRON LOGGING HOLE

(G) KIOWA STE
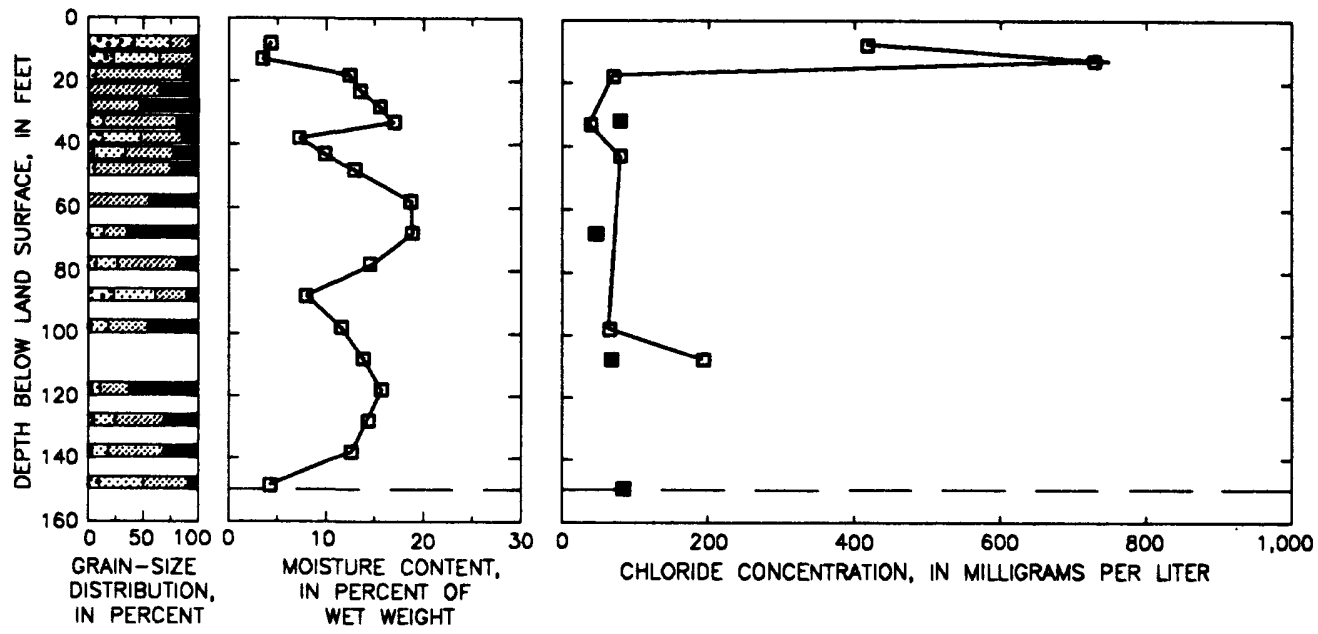
DISTRIBUTION WET WEIGHT
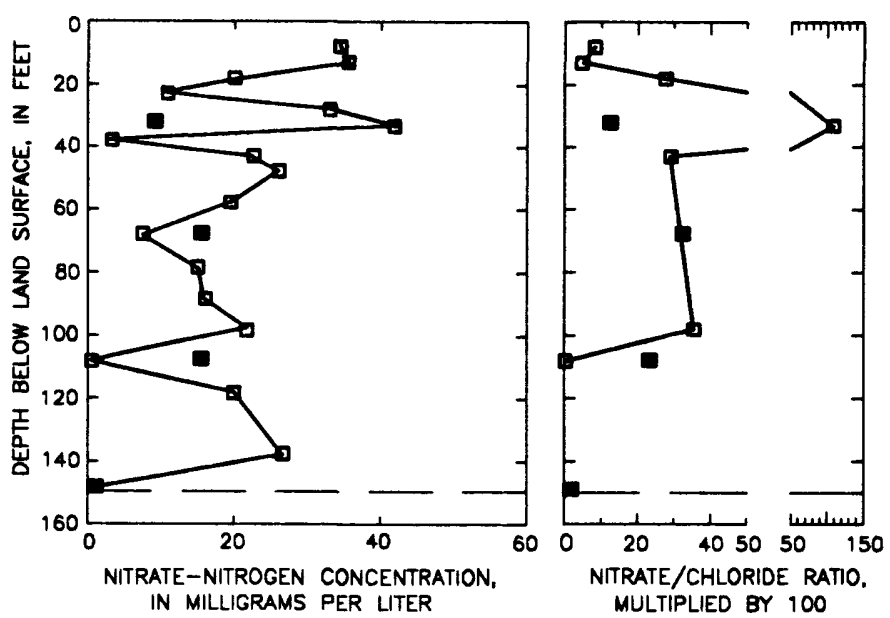

EXPLAKTION

GRAIN SIZE-

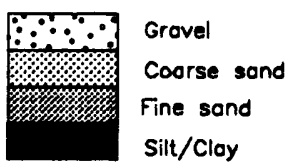

NOTE:

Groin-size distribution within each soil horizon shown is extrapolated from

1.5- $\mathrm{ft}$ core centered ot middle of horizon

- DATA FROM SOIL CORES

- MEOLN OF LYSIMETER DATA AT INDICATED DEPTHS IN MILLIGRAMS PER LITER

Flgure 13. Continued. 
(A) CHEYENNE-II SITE
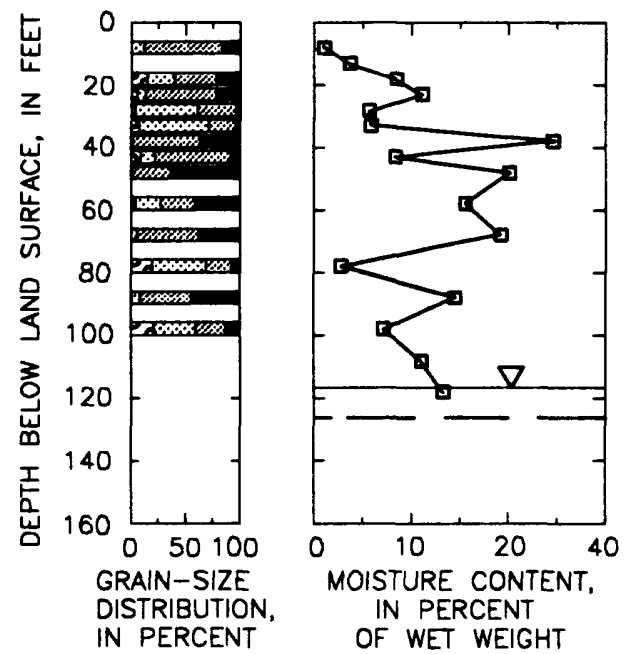

\section{EXPLANATION}

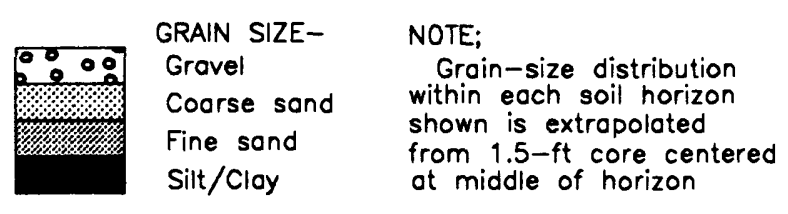

- DATA FROM SOIL

CORES

- MEDIAN OF LYSIMETER

DATA AT INDICATED

DEPTHS

- BOTTOM OF NEUTRON

LOGGING HOLE

$\nabla$ WATER TABLE (4-27-88)
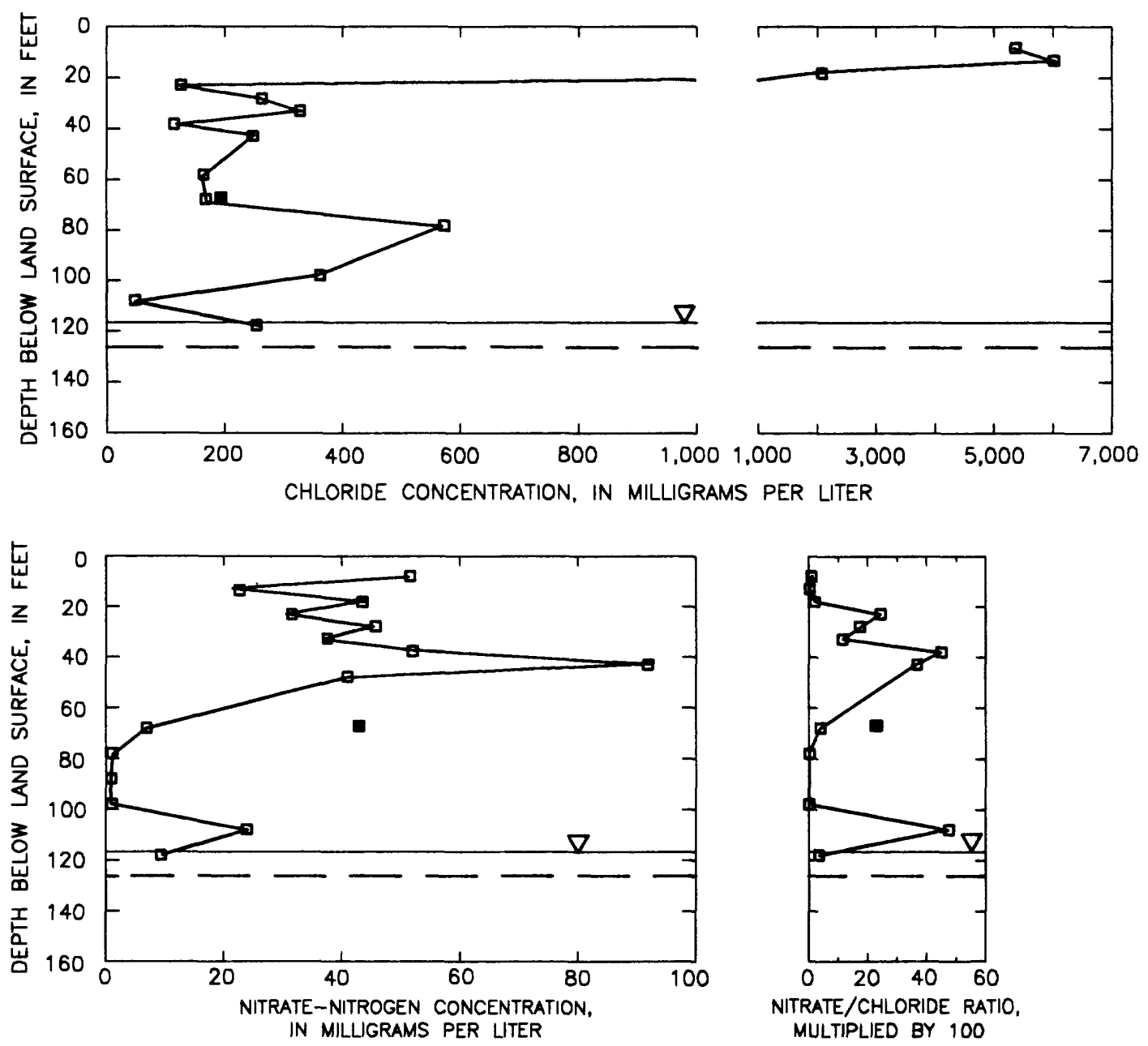

Figure 13. Continued.

grained deposits at the Cheyenne-I and Cheyenne-II sites (fig. 13). At all these sites, nitrate- $N$ concentrations decreased to less than $10 \mathrm{mg} / \mathrm{L}$ in both soil- core and suction-lysimeter samples (tables 7 and 17). At Choctaw, Kiowa, and Cajon, nitrate- $\mathrm{N}$ concentrations were about $1 \mathrm{mg} / \mathrm{L}$ near the water table 

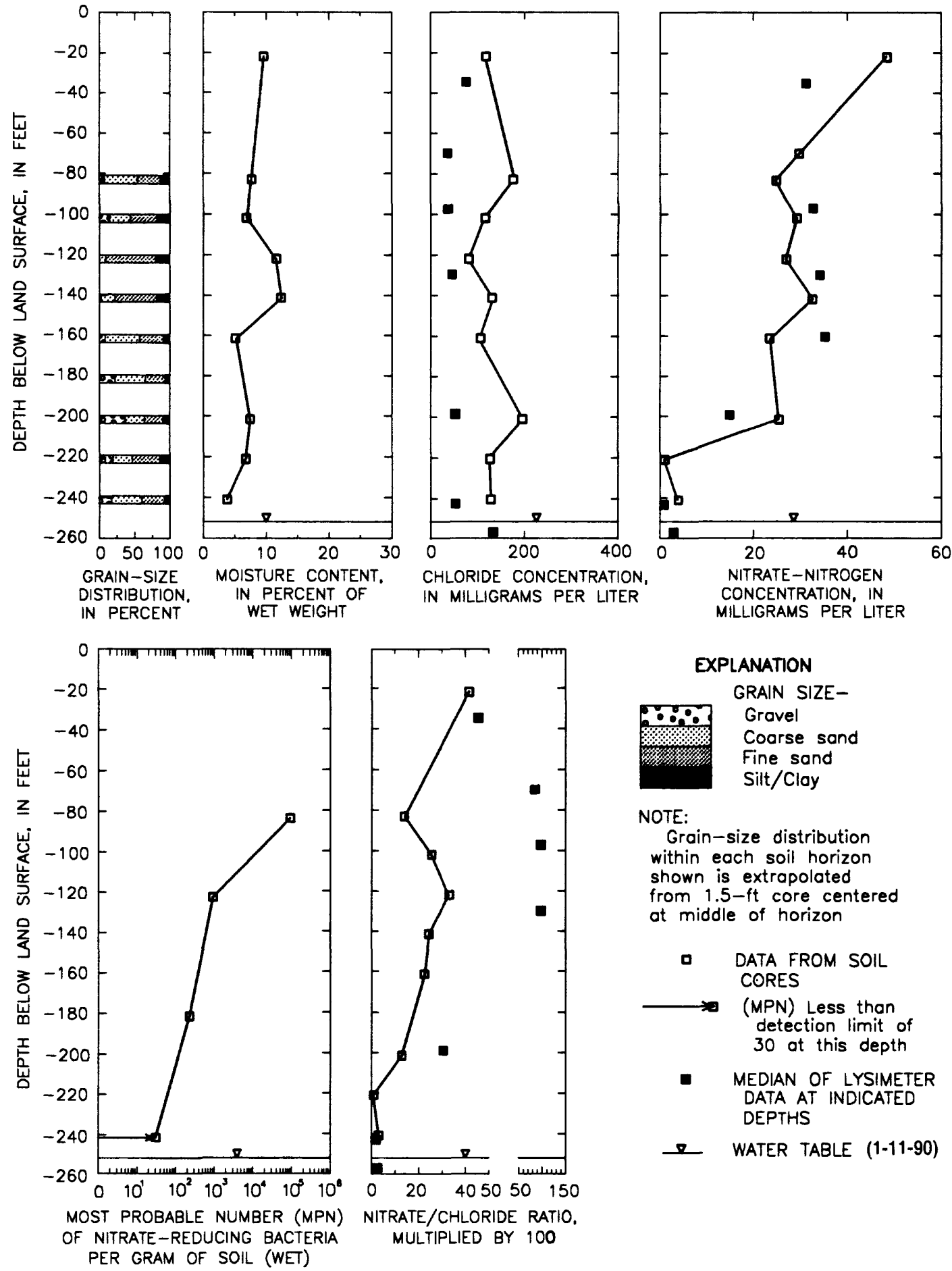

EXPLANATION

GRAIN SIZE-

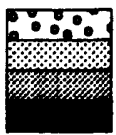

Gravel

Coarse sand

Fine sand

Silt/Clay

NOTE:

Grain-size distribution within each soil horizon shown is extrapolated

from 1.5-ft core centered

at middle of horizon

- DATA FROM SOIL CORES

$\longrightarrow$ (MPN) Less than detection limit of 30 at this depth

- MEDIAN OF LYSIMETER DATA AT INDICATED DEPTHS

$\rightarrow$ WATER TABLE $(1-11-90)$

Figure 13. Continued.

(tables 7 and 17), although more recent evidence discussed later attributes the very low nitrate concentration at depths below $200 \mathrm{ft}$ at Cajon to the absence of wastewater below this depth. Although monitoring has only recently resumed at the Cheyenne-I site, scant data obtained so far also suggest a similar possible explanation, and (or) dilution with ground water, for the nitrate-concentration profile there as well.

Three explanations for the observed decrease in nitrate concentration are (1) microbial nitrate reduc- 
tion, (2) mixing of the wastewater with low-nitrate ground water in the capillary fringe, and (3) the wastewater wetting front has reached the water table, but the actual wastewater has yet to arrive. If microbial nitrate reduction were responsible for the reduced nitrate concentrations, chloride concentrations would remain unchanged (because chloride is biologically unreactive) and the nitrate-to-chloride ratio would decrease. Shallow ground water at Cheyenne-I and Choctaw had higher chloride concentrations than did wastewater in the unsaturated zone (table 17). Therefore, if mixing with ground water were solely responsible for the reduced nitrate concentrations, nitrate-to-chloride ratios would decrease and chloride concentrations would increase. (Although the principle is the same, the pattern differs at Cajon because the chloride concentration is much lower in ground water than in the wastewater.)

Inspection of available data (tables 7 and 17, fig. 13) indicates that chloride concentrations remain relatively unchanged; whereas, nitrate-to-chloride ratios decrease dramatically opposite the zones where nitrogen concentrations also decrease. Thus, these data suggest that microbial nitrate reduction might be partly responsible for the observed decrease in nitrate concentrations. The presence of high numbers of nitrate-reducing bacteria opposite zones where nitrate concentrations also decrease at the two sites where bacterial analyses were performed (Cheyenne-I and Cajon) (fig. 13, table 9) lend further support to this inference. It should be noted, however, that the presence of these bacteria indicates only that the potential for nitrate reduction exists. The numbers found cannot be used to infer in situ activity - that is, the degree to which possible nitrate removal proceeds.

The fact that nitrate concentrations decreased a significant distance above the water table at the Cheyenne-I and Cheyenne-II sites (fig. 13) would seem to preclude the possibility of ground-water mixing at these sites. However, the results of ongoing monitoring at Cajon since 1991 described by Schroeder and others (1993) do raise the possibility of a similar or related explanation for the low nitrate concentrations at depth at the Cheyenne sites. The soil surface is commonly soaked with tapwater from the local residence prior to drilling a hole for installation of a seepage pit. Any residual soil moisture (prior to discharge of wastewater) plus this added water would be "pushed" ahead (piston flow) of the advancing wastewater front, as the results at Cajon have shown. If this was the source of water in the lysimeters at 92.5 and $106 \mathrm{ft}$ (the lysimeter at $113 \mathrm{ft}$ was below the water table in 1988-89) at Cheyenne-I, analyses in table 7 indicate that this soil moisture should be lower in chloride than is local ground water, as was found to be the case. There is a substantial increase in nitrate in the last samples collected in July and August 1989 for analysis from the lysimeters at 92.5 and $106 \mathrm{ft}$, respectively (table 10 ). Unfortunately, sample collection then was terminated at Cheyenne-I and it was not resumed until June 1993. Preliminary results from the resumed monitoring have confirmed the existence of high nitrate concentrations in the lysimeters at 92.5 and $106 \mathrm{ft}$, as well as in the lysimeter at $113 \mathrm{ft}$ (the water table had subsequently declined below $113 \mathrm{ft}$ ). Sampling is continuing at Cheyenne-I for analysis of nitrate and nitrogen isotopes as well as a number of chemical constituents.

\section{DENITRIFICATION}

As stated above, denitrification may be partly responsible for the decrease in nitrate concentration as wastewater moves through the unsaturated zone in the study area. Results of standard plate counts in table 8 show an abundance of aerobic, heterotrophic bacteria in the unsaturated zone. Degradation of organic carbon by these microorganisms probably is the main source of increased carbon dioxide, whose content is 2.94 volume percent in soil gas from $47 \mathrm{ft}$ at Cheyenne-I (air is 0.03 percent). As long as molecular oxygen is present, the bacteria will use it as a terminal electron acceptor. In the absence of oxygen, a large and diverse group of nitrate-respiring heterotrophs, including Pseudomonas, can use nitrogen instead of oxygen as the terminal electron acceptor. The pathway for denitrification can be represented by a series of steps as follows:

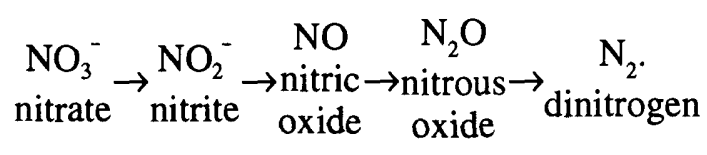

The multiple steps in this process are carried out by separate bacteria, and denitrification refers only to those later steps that produce the gaseous end products ( $\mathrm{NO}, \mathrm{N}_{2} \mathrm{O}$, and $\mathrm{N}_{2}$ ); however, the term denitrification commonly is loosely applied to the entire process of nitrate reduction, except when the end product is ammonia.

Although there are nitrate-respiring microorganisms capable of reducing nitrate to ammonia, ground-water studies in other areas suggest that this reaction is either unlikely or of very minor importance in this study. Smith and Duff (1988) initially reported denitrification only, with no evidence of dissimilatory nitrate reduction to ammonia, in a 
shallow sand and gravel aquifer in Cape Cod, Massachusetts. There, the aquifer was contaminated by secondary-treated wastewater in which nitrate-N was $13 \mathrm{mg} / \mathrm{L}$ and organic carbon was $12 \mathrm{mg} / \mathrm{L}$. Subsequent ${ }^{15} \mathrm{~N}$ studies on dissolved ammonia in the same aquifer confirmed dissimilatory nitrate reduction but concluded that it seemed to be only a minor sink for nitrate (Smith and others, 1991). At low organic carbon-to-nitrate ratios, denitrification is favored over dissimilatory nitrate reduction to ammonia (Tiedje and others, 1982). In fact, an important consideration is whether sufficient degradable carbon even exists in the wastewater at the study site to effect complete denitrification.

Experiments elsewhere indicate that soil organic matter is an ineffective long-term energy source to effect complete denitrification (Stewart and others, 1979). This is why addition of an organic carbon source to soils fertilized with inorganic nitrogen aids denitrification (Adelman and Spalding, 1988). Addition of natural and synthetic organic carbon to wastewater also has been shown to increase denitrification (Lance and Whisler, 1976; Lance and others, 1980; Rice and Bouwer, 1984; and Lance, 1986). From the results of soil-column experiments, Stewart and others (1979) concluded that wastewater is only slowly available to degradation by denitrification. However, such slow rates may not necessarily be a hindrance to denitrification at the study sites, where wastewater-transit velocities in the unsaturated zone are estimated to be $0.07-1 \mathrm{ft} / \mathrm{d}$ (table 15) and times to reach the water table at $150 \mathrm{ft}$ range from almost 6 months to almost 6 years.

Experimental data indicate that an organic carbonto-nitrate- $\mathrm{N}$ ratio close to 1 is needed to effect denitrification (McCarty and others, 1969; Stewart and others, 1979). This matches closely the stoichiometry of model reactions for denitrification of methanol $\left(\mathrm{CH}_{3} \mathrm{OH}\right)$ and sugars $\left(\mathrm{CH}_{2} \mathrm{O}\right)_{n}$ :

$$
\begin{gathered}
6 \mathrm{NO}_{3}^{-}+5 \mathrm{CH}_{3} \mathrm{OH}+\mathrm{H}^{+} \rightarrow 3 \mathrm{~N}_{2}+8 \mathrm{H}_{2} \mathrm{O}+5 \mathrm{HCO}_{3}^{-} \\
4 \mathrm{NO}_{3}^{-}+5\left(\mathrm{CH}_{2} \mathrm{O}\right) \rightarrow 2 \mathrm{~N}_{2} \\
+\mathrm{H}_{2} \mathrm{CO}_{3}+2 \mathrm{H}_{2} \mathrm{O}+4 \mathrm{HCO}_{3}^{-} .
\end{gathered}
$$

The average organic carbon-to-nitrogen mass ratio in wastewater calculated from data (tables 12 and 17) at four sites (Vasquez, Choctaw, Kiowa, and CheyenneII) is 0.65 (equivalent to a stoichiometric ratio of 0.76). The data suggest that wastewater at the study sites is at least somewhat deficient in the organic carbon needed for complete denitrification. The organic carbon deficit is even greater if analyses of samples from lysimeters can be considered to be reliable indicators of bioavailable carbon. The few data available (table 10), principally from lysimeters at Cheyenne-I and Cajon, show that aqueous organic carbon concentrations at all depths are much lower than the dissolved organic carbon concentrations in wastewater itself (table 12). Furthermore, no depthrelated trend in concentration can be discerned. The result is that organic carbon-to-nitrate- $\mathrm{N}$ ratios are as low as 0.1 at relatively shallow depths where nitrate concentration is still high. However, caution is necessary in interpreting the significance of this result as it is not known whether a large fraction of the available organic carbon may be retained on particle surfaces or even on the ceramic lysimeter cup itself. At the Cape Cod aquifer contaminated by secondary wastewater cited earlier, denitrification was found to occur despite a decrease in dissolved organic carbon from $12 \mathrm{mg} / \mathrm{L}$ in the wastewater effluent to less than $2.5 \mathrm{mg} / \mathrm{L}$ in the contaminated ground water (Smith and Duff, 1988). Model calculations yielded 0.77 carbon atoms mineralized (oxidized to inorganic carbon) for each nitrate ion reduced by denitrification (Smith and others, 1991).

Whether sufficient organic carbon is available to effect complete denitrification becomes less important if autotrophs (chemlithotrophs) capable of using inorganic elements, rather than organic carbon, as an energy source (electron donor) are present. Mariotti and others (1988) and Böttcher and others (1990) cite evidence for denitrification in an aquifer mediated by the chemlithotrophic bacterium Thiobacillus denitrificans using sulfur in pyrite $\left(\mathrm{FeS}_{2}\right)$ as the electron donor according to the reaction:

$$
\begin{gathered}
14 \mathrm{NO}_{3}^{-}+5 \mathrm{FeS}_{2}+4 \mathrm{H}^{+} \rightarrow 7 \mathrm{~N}_{2} \\
+10 \mathrm{SO}_{4}^{2-}+5 \mathrm{Fe}^{2+}+2 \mathrm{H}_{2} \mathrm{O}
\end{gathered}
$$

If both iron and sulfur act as electron donors, the reaction is represented by:

$$
\begin{gathered}
6 \mathrm{NO}_{3}^{-}+2 \mathrm{FeS}_{2}+2 \mathrm{H}_{2} \mathrm{O} \rightarrow 3 \mathrm{~N}_{2} \\
+2 \mathrm{FeOOH}+4 \mathrm{SO}_{4}^{2-}+2 \mathrm{H}^{+} .
\end{gathered}
$$

For a comprehensive discussion of both heterotrophic and autotrophic denitrification in ground water, the reader is referred to a recent review by Korom (1992).

In this study, an abundance of nitrate-reducing bacteria in the unsaturated zone at the Cheyenne-I and Cajon sites (table 9) and high oxygen levels (in soil gas at Cheyenne-I and in soil moisture at Cajon) were 
found despite experimental evidence that denitrification does not occur above even a very low oxygen threshold (Nakajimi and others, 1984, and Rönner and Sörensson, 1985). These results suggest the existence of microenvironments where oxygen is absent and denitrification can occur. The brownish coloration of nearly all recovered cores indicates a general absence of anaerobic (sulfidic) layers. However, a few exceptions (such as several feet of clay-rich, olive-gray soil near the water table at Cheyenne-I and Cheyenne-II) were found and these could be zones where denitrification, perhaps by chemlithotrophs, might occur.

Additional, indirect evidence for denitrification was sought from measurements of the ratio of nitrogen-15 to nitrogen-14 in nitrate. Applications and limitations of the method have been reviewed by Hübner (1986) and Mariotti (1986). Isotope ratios are expressed in the commonly used delta $(\delta)$ notation (Fritz and Fontes, 1980):

$$
\delta^{15} \mathrm{~N}=\left[\left(\mathrm{R}_{\text {sample }} / \mathrm{R}_{\text {standard }}\right)-1\right] \times 1,000,
$$

where $R$ is the ratio of nitrogen-15 to nitrogen-14 in the sample and standard, and the standard is air (atmospheric nitrogen). Although denitrification is a complex multi-step reaction, isotopic fractionation accompanying denitrification has been found to follow the simple kinetics of a first-order, irreversible reaction (Mariotti and others, 1982) for which the approximate equation of a Rayleigh process is (Fritz and Fontes, 1980, and Létolle, 1980):

$$
\delta^{15} \mathrm{~N}=\delta^{15} \mathrm{~N}_{0}+\varepsilon \ln \left[\mathrm{NO}_{3}^{-}\right] /\left[\mathrm{NO}_{3}^{-}\right]_{0}
$$

This equation expresses the relation between isotopic composition of the residual nitrate $\left(\delta^{15} \mathrm{~N}\right)$ and nitrate concentration $\left[\mathrm{NO}_{3}\right]$ at any time. The subscript " 0 " refers to the initial (time $=0$ ) isotope ratio and nitrate concentration, and the constant $\varepsilon$ is the isotopicseparation (enrichment) factor.

Isotopic fractionation during denitrification varies with environmental conditions and the type of bacterium. The largest value of $\varepsilon$ reported for denitrification in a ground-water system is $-30 \pm 6$ permil in the Kalahari Desert (Vogel and others, 1981, and Heaton and others, 1983). Böttcher and others (1990) measured an $\varepsilon$ value of -15.9 permil in ground water beneath arable land where denitrification was carried out by chemlithotrophic bacteria, and an enrichment value of about -30 permil can be inferred from data for shallow ground water beneath an irrigated field in the middle of the Imperial Valley (Schroeder and others, 1991). Denitrification, with an $\varepsilon$ value of -13.9 permil, was reported in ground water from the shallow sand-and-gravel aquifer in Cape Cod (Smith and others, 1991), a site that has some important similarities to, as well as differences from, the Victor Valley study area. Disposal of secondary-treated sewage effluent having a nitrate- $\mathrm{N}$ concentration of 13 $\mathrm{mg} / \mathrm{L}$ and a dissolved organic carbon concentration of $12 \mathrm{mg} / \mathrm{L}$ onto sand infiltration beds for more than 50 years has produced an extensive plume of contaminated ground water at the Cape Cod site. Despite these comparatively large enrichment factors, in most ground-water studies where denitrification has been proven, $\varepsilon$ is reported to be only about -5 permil, which is much less than values measured in the laboratory (Mariotti and others, 1988) and in the few ground-water studies cited above. Some possible explanations for the low isotopic enrichment usually observed in nature are discussed by Mariotti and others (1988).

All nitrogen-isotope data initially obtained for this study from suction lysimeters (table 10) and monitoring wells (table 14) are reproduced in table 18. To ascertain isotopic evidence for denitrification, samples representing low nitrate concentrations were sought from the unsaturated zone. No completely unambiguous data were obtained, partly because of the difficulty in collecting a sufficiently large sample for analysis and partly because no samples were collected

Table 18. Nitrogen isotope data from selected suction lysimeters and monitoring wells, 1989-90

[Data taken from tables 10 and $14 ; \mathrm{ft}$, foot; $\mathrm{mg} / \mathrm{L}$, milligram per liter; mo/yr, month and year]

\begin{tabular}{lcccc}
\hline $\begin{array}{c}\text { Site } \\
\text { name }\end{array}$ & $\begin{array}{c}\text { Depth } \\
(\mathrm{ft})\end{array}$ & $\begin{array}{c}\text { Date } \\
(\mathrm{mo} / \mathrm{yr})\end{array}$ & $\begin{array}{c}\text { Nitrate } \\
(\mathrm{mg} / \mathrm{L} \\
\text { as N) }\end{array}$ & $\begin{array}{c}\delta^{15} \mathrm{~N} \\
(\mathrm{per}- \\
\mathrm{mil})\end{array}$ \\
\hline \multicolumn{5}{c}{ Suction lysimeters } \\
\hline Cheyenne-I & 37 & $7 / 89$ & 32 & 8.7 \\
Cheyenne-I & 42 & $7 / 89$ & 38 & 7.9 \\
Cheyenne-I & 63 & $7 / 89$ & 31 & 8.7 \\
Cheyenne-I & 73 & $7 / 89$ & 35 & 8.3 \\
Cheyenne-I & 92.5 & $7 / 89$ & 32 & 7.8 \\
Cajon & 243 & $6 / 90$ & .8 & 7.1 \\
\hline & \multicolumn{5}{c}{ Wells } & & \\
\hline Apple Ranchos & 199 & $8 / 89$ & 4.1 & 8.1 \\
Rincon & 233 & $8 / 89$ & 1.0 & 5.3 \\
\hline
\end{tabular}


in which wastewater was known to be present but at reduced concentrations. Ideally, the laboratory requires $5 \mathrm{mg}$ nitrate as nitrogen; and, although isotopic analysis can be done on smaller quantities, the risk of contamination by atmospheric nitrogen during preparation of the sample for analysis increases. Composite samples were collected over a period as long as a month. All five samples from depths between 37 and $92.5 \mathrm{ft}$ at Cheyenne-I had a $\delta^{15} \mathrm{~N}$ of about 8 permil. All these samples also contained high nitrate concentrations, and thus little or no shift in isotopic composition would be expected. In fact, these isotope ratios for nitrate are only a few permil less than published ratios for nitrogen in septic-tank wastewater itself (Martin, 1980, and Mariotti and others, 1988), a result that is consistent with fairly complete nitrification of wastewater in the unsaturated zone. Partial nitrification would lead to much greater depletion of ${ }^{15} \mathrm{~N}$ in the nitrate (Delwiche and Steyn, 1970).

On the basis of data obtained during the previous 13 months (table 10), it was expected that the July 1989 composite sample from the lysimeter at $92.5 \mathrm{ft}$ at Cheyenne-I would contain low but sufficient nitrate for isotopic analysis. However, because the nitrate concentration was found to be anomalously high in comparison with previously collected samples from this depth, a sample from the lysimeter at $243 \mathrm{ft}$ at the Cajon site was collected the following year for isotope analysis. Although the nitrate- $\mathrm{N}$ concentration of $0.8 \mathrm{mg} / \mathrm{L}$ is low, the sample shows no enrichment in ${ }^{15} \mathrm{~N}\left(\delta^{15} \mathrm{~N}=7.1\right.$ permil). If the decrease in concentration were due to denitrification, even the smallest published values for isotopic enrichment would predict a $\delta^{15} \mathrm{~N}$ of at least 20 permil. The apparent lack of ${ }^{15} \mathrm{~N}$ enrichment may indicate that this sample is from a depth that may have been below the water table (at least at times) although at the time of collection in June 1990 it was above the water table. If the sample from $243 \mathrm{ft}$ at Cajon does, in fact, represent soil moisture derived from regional ground water rather than wastewater, it would not be a surprise that its isotopic composition is similar to that of ground-water samples from Apple Ranchos and Rincon (table 18). Whatever the source of the water in this lysimeter may be, it is clear from ongoing monitoring that it was not wastewater because wastewater had not yet reached this depth in 1993 (Schroeder and others, 1993).

One possible explanation for the nitrogen-isotope values observed in the study area is that the isotopic composition of nitrate is nearly the same in undenitrified wastewater from the unsaturated zone and in ground water where the nitrate is from natural sources (prior to development). It then would be impossible to distinguish, on the basis of isotopes alone, between discharge to the ground water of completely denitrified wastewater (dilution of ground-water nitrate) or of undenitrified wastewater (mixing into low-nitrate ground water). If there were only partial denitrification, followed by the mixing of partially denitrified wastewater and ground water, both theory and the example discussed by Mariotti and others (1988) suggest that isotopic evidence for denitrification should exist.

Additional sampling is continuing, on a limited basis, to test for isotopic evidence of denitrification in the study area (table 19). Unfortunately, some lysimeters no longer operate (table 4) and one of the more important sites, Cheyenne-I, subsequently was covered by a concrete driveway. Samples are being collected from lysimeters at Cajon where the water table as of late 1991, when monitoring resumed, had declined below the piezometer at $266 \mathrm{ft}$ (table 3) that lies beneath the series of eight lysimeters at this site (table 4). Although the coarseness of the soils at the Cajon site would seem to make it a less favorable environment for denitrification to occur than many other parts of Victor Valley, preliminary data on samples from the uppermost six lysimeters between 35 and $199 \mathrm{ft}$ indicated isotopic enrichment with an $\varepsilon$ value of about -10 permil on the basis of a $\delta^{15} \mathrm{~N}$ of 14.8 permil at the $199-\mathrm{ft}$ lysimeter (Schroeder and Martin, 1992). The ${ }^{15} \mathrm{~N}$ enrichment is accompanied by a large increase in iron, sulfate, and free hydrogen ion (pH approximately 4) at this depth (Schroeder and others, 1993). These chemical changes seem to be similar to those from an example (Postma and others, 1991) and model (Engesgaard and Kipp, 1992) of aqueous chemical changes that accompany nitrate removal by pyrite oxidation in a ground-water system (denitrification by chemlithotrophs).

The changes that have occurred in specific conductance at the Cajon site between initial monitoring (1988-90) and the more recent monitoring (after 1991) provide ample evidence for the importance of maintaining monitoring in the unsaturated zone for a period perhaps as long as several years. The relative constancy in specific conductance for successive samples above $199 \mathrm{ft}$ during the current sampling period (table 19) in comparison with the earlier period (table 7) that immediately followed installation of the lysimeter are notable.

The lysimeters were sampled as many as 11 times between November 5, 1991, and March 29, 1993. Selected data are given in table 19; additional data are given by Schroeder and others (1993). During this 
Table 19. Specific conductance, concentrations of selected chemical constituents, and nitrogen-isotope ratios in samples from lysimeters at Cajon residential site, 1991-93

[Nitrogen and organic carbon concentrations from November 5, 1991; oxygen concentrations from April 22, 1992; and isotope data from November 13, 1991. ft, foot; $\mu \mathrm{S} / \mathrm{cm}$, microsiemen per centimeter at 25 degrees Celsius; --, no data]

\begin{tabular}{|c|c|c|c|c|c|c|c|c|c|c|c|c|}
\hline \multirow[b]{2}{*}{$\begin{array}{l}\text { Depth } \\
\text { (ft) }\end{array}$} & \multicolumn{6}{|c|}{ Specific conductance $(\mu \mathrm{S} / \mathrm{cm})$} & \multicolumn{6}{|c|}{ Constituent concentration $(\mathrm{mg} / \mathrm{L})$} \\
\hline & $\begin{array}{l}9-23 \\
1991 \\
\end{array}$ & $\begin{array}{c}11-05 \\
1991 \\
\end{array}$ & $\begin{array}{c}11-13 \\
1991 \\
\end{array}$ & $\begin{array}{l}2-13 \\
1992 \\
\end{array}$ & $\begin{array}{l}4-22 \\
1992 \\
\end{array}$ & $\begin{array}{l}3-29 \\
1993 \\
\end{array}$ & $\begin{array}{l}\text { Nitrate } \\
\text { as } \mathrm{N}\end{array}$ & $\begin{array}{l}\text { Ammo- } \\
\text { nium, } \\
\text { as N }\end{array}$ & $\begin{array}{l}\text { Kjeldahl } \\
\text { nitro- } \\
\text { gen }\end{array}$ & $\begin{array}{l}\text { Carbon, } \\
\text { organic }\end{array}$ & $\begin{array}{c}\text { Oxygen, } \\
\text { dis- } \\
\text { solved }\end{array}$ & $\begin{array}{c}\delta^{15} \mathrm{~N} \text {, in } \\
\text { nitrate } \\
\text { permil) }\end{array}$ \\
\hline 35 & 585 & 462 & 472 & 478 & 473 & 448 & 28 & 0.03 & 0.5 & 2.9 & 3.7 & 10.5 \\
\hline 70 & 755 & 491 & 485 & 486 & 525 & 435 & 27 & .15 & .7 & 3.4 & 4.5 & 9.5 \\
\hline 97.5 & 547 & 517 & 493 & 491 & 488 & 468 & 34 & .08 & .4 & 3.0 & 4.4 & 8.2 \\
\hline 130 & 617 & 590 & 547 & 540 & 525 & 470 & 38 & .15 & .8 & 4.2 & -- & 7.8 \\
\hline 160 & 588 & 547 & 564 & 567 & 555 & 493 & 36 & .14 & .7 & 3.5 & 6.1 & 7.8 \\
\hline 199 & 468 & 391 & 395 & 401 & 418 & 535 & 18 & .24 & .4 & 2.1 & 5.0 & 14.8 \\
\hline 243 & 487 & 274 & 248 & 285 & -- & 264 & .52 & .04 & .5 & 4.4 & 7.1 & -- \\
\hline 257 & 358 & 1,017 & 1,329 & 1,013 & 1,003 & 1,088 & .13 & .05 & .8 & 14 & -- & -- \\
\hline
\end{tabular}

period, specific conductance showed no trend (average unsigned difference of 4 percent between successive samples) in the five lysimeters above 199 $\mathrm{ft}$ and within the wastewater zone, and also showed no trend (average unsigned difference of 10 percent between successive samples) in the two lysimeters below $199 \mathrm{ft}$ and beneath the advancing wastewater front. Concurrently, the specific conductance increased monotonically by almost 40 percent in the lysimeter at $199 \mathrm{ft}$ during the same 1.5 -year period, presumably as lower conductance soil moisture was being displaced by higher conductance wastewater (Schroeder and others, 1993).

The fact that the effect of sampling "artifacts" is much more pronounced and persists much longer for major ions than for nitrate strongly suggests that leaching of material used to backfill the drilled holes is the main source of contamination in early samples. With time, equilibration between the soil moisture (wastewater) and minerals that surround the suction-lysimeter cup is reestablished as the readily soluble salts are leached from the backfill material. Monitoring is continuing at the Cajon site to determine when (if) the advancing wastewater reaches the lysimeter at $243 \mathrm{ft}$. The concrete driveway was removed and monitoring resumed at the Cheyenne-I site in June 1993 to determine whether wastewater had reached the lowermost lysimeters at this site when monitoring was initially stopped in 1989. It is hoped that comparison of nitrogen-isotope data from both sites and in ground water will indicate whether isotope ratios can be used to distinguish wastewater nitrate from natural nitrate in the ground water.

\section{TOTAL BACTERIA AND FECAL COLIFORMS}

Wastewater contains a wide variety of pathogenic bacteria, viruses, protozoa, and worms. One published average biological characteristic for domestic wastewater is: total bacteria $=5.6-8 \times 10^{7} \mathrm{CFU}$ (colonyforming units) $/ 100 \mathrm{~mL}$, total coliform $=2 \times 10^{6}$ MPN/100 mL, fecal coliform and fecal streptococci $=3 \times 10^{4} \quad \mathrm{MPN} / 100 \mathrm{~mL}$, and enteric viruses $=32-7,000 \mathrm{PFU}$ (plaque-forming colonies) $/ \mathrm{L}$ (Viraraghavan, 1976, and Siegrist, 1977). Other values for average total-bacteria and fecal-coliform densities that exceed the above values by a factor of about 10 also have been reported (Siegrist, 1977; Canter and Knox, 1985). These published values can be compared with measured ranges of $1.2 \times 10^{8}$ to $9.4 \times 10^{8} \mathrm{CFU} / 100 \mathrm{~mL}$ for total (heterotrophic) bacteria and $5.2 \times 10^{4}$ to $3.9 \times 10^{5} \mathrm{CFU} / 100 \mathrm{~mL}$ for fecal coliform in wastewater at five residences in the study area (table 13).

For this study, fecal coliforms were the only enteric microorganisms analyzed. Historically, fecal coliforms have been widely used as a reliable indicator of fecal contamination (Clark and Kabler, 1964). Persistence of other microorganisms in ground water, in comparison with Escherichia coli, has been reported to range from 0.02 to 3 times longer for seven common pathogenic bacteria and from 1.3 to 6 times longer for four viruses (Matthess and others, 1988). On the basis of these comparisons, the disappearance of fecal coliforms from soils only a short distance from the seepage pits in Victor Valley suggests that other pathogenic microorganisms also 
would be unlikely to reach the water table given the long distance and traveltimes, although additional study on the movement and attenuation of viruses is needed.

Sinton (1986) found significant movement of fecal coliforms from seepage pits to ground water in a system with an experimental design similar to that of this study. However, the water table at that study site was only $3.5 \mathrm{~m}(11.5 \mathrm{ft})$ below the bottom of a seepage pit in a gravel aquifer in which downward percolation velocities exceeded $5 \mathrm{~m} / \mathrm{h}(16 \mathrm{ft} / \mathrm{h})$. Wherever silt and clay are present, as in this study area, removal of non-native bacteria and viruses generally requires less than $1 \mathrm{~m}(3 \mathrm{ft})$ of bulk soil that is free of channels or cracks (Brown and others, 1979, and Lance and Gerba, 1984). Physical straining (filtration) and adsorption (Canter and Knox, 1985) probably are the most important mechanisms of fecal coliform removal in the soils at Victor Valley. Additional factors that might favor rapid attenuation are competition with native bacteria for nutrients, antagonism from actinomycetes and other groups of bacteria such as Pseudomonas and Bacillus (Matthess and others, 1988), and an unsaturated (as opposed to saturated) flow regime below the seepage pits (Hagedorn and others, 1978, and Reneau, 1978).

Bacterial analyses were done on soils, rather than on water, because of the overwhelming predilection of bacteria for attachment to the solid rather than the aqueous phase in aquifers that contain even a smaller proportion of fine material (Harvey and others, 1984, and Smith and Duff, 1988) than is present in Victor Valley. Although percolating wastewater provides the medium for bacterial transport through the unsaturated zone, direct collection of aqueous samples for reliable analysis of bacteria is not possible because passage of the water through the small pore openings of the lysimeter's ceramic cup results in bacterial removal factors of $10^{2}-10^{6}$ (Dazzo and Rothwell, 1974).

Total-bacteria densities as high as $10^{4} \mathrm{CFU} / \mathrm{g}$ were measured in core samples (table 8 ), but the significance of these findings to disposal of wastewater in Victor Valley is uncertain because the measurement does not distinguish between native and wastewater populations. The high numbers may be due to the growth of native bacteria on wastewater organic carbon. However, the general occurrence of high counts near the base of the seepage pits does suggest a wastewater component, and, if so, the nearly universal absence of measurable heterotrophic bacteria (assuming the standard-methods agar or broth used is appropriate to support growth in the laboratory) at greater depths (except below the water table at Cheyenne-I) implies their effective removal in the unsaturated zone.

\section{OTHER CONTAMINANTS IN WASTEWATER}

Beginning about 1980, it was recognized that synthetic organic chemicals might exist in septic-tank effluent, and a few analyses have been done (Viraraghavan and Hashem, 1986, and references therein). Volatile (or purgeable) priority pollutants, which are commonly used solvents, and acidextractable priority pollutants, such as phenols, have chemical properties that are favorable for their transport, making them the trace organic constituents of greatest concern (Viraraghavan and Hashem, 1986). For this study, extractable organic compounds were analyzed on core samples and purgeable-plus-extractable organic compounds were analyzed on wastewater samples from five residential sites using gas chromatographic/mass spectrometric methods described by Wershaw and others (1987). The core samples analyzed were from 97 to $99 \mathrm{ft}$ at Toltec, 22 to $24 \mathrm{ft}$ at Cheyenne-I, 28 to $30 \mathrm{ft}$ at Choctaw, 27 to $29 \mathrm{ft}$ at Kiowa, and 32 to $34 \mathrm{ft}$ at Cheyenne-II. With the exception of the background sample at Toltec, the depths selected for analysis are near the bottom of the seepage pit and therefore would be most likely to contain organic contaminants if they were present. The detection limit for most extractable priority pollutants was $200 \mu \mathrm{g} / \mathrm{kg}$, and none were found in any of the five core samples.

The detection limit was $0.2 \mu \mathrm{g} / \mathrm{L}$ for most purgeable organic priority pollutants and $5 \mu \mathrm{g} / \mathrm{L}$ for most extractable organic priority pollutants analyzed in wastewater. Of 85 priority pollutants analyzed, 17 were detected in at least one of the six samples from five residential sites; however, their concentrations were generally low-except at Cheyenne-II, where wastewater from both the septic tank and seepage pit was analyzed (table 20). It is likely that the synthetic organic chemical concentrations in domestic wastewater are generally low, as was reported by Viraraghavan and Hashem (1986) from their analysis of 11 purgeable priority pollutants. Where comparatively high concentrations do occur in this study, they seem to be associated with inappropriate disposal practices that were unique to a particular site (Cheyenne-II).

In addition to the priority pollutants, other organic compounds were tentatively identified in wastewater from Choctaw and Cheyenne-II. Identification was by comparison of spectrums corresponding to gaschromatographic peak maximums against a comput- 
Table 20. Organic priority pollutants detected in wastewater samples from septic tanks and seepage pits

[Concentrations in micrograms per liter; ND, not detected; --, not analyzed]

\begin{tabular}{|c|c|c|c|c|c|c|}
\hline \multirow{2}{*}{$\begin{array}{l}\text { Organic priority } \\
\text { pollutant }\end{array}$} & \multicolumn{4}{|c|}{ Septic tanks } & \multicolumn{2}{|c|}{ Seepage pits } \\
\hline & Cheyenne- $\mathrm{I}^{1}$ & Choctaw & Kiowa $^{2}$ & Cheyenne-II & $\overline{\text { Vasquez }}$ & Cheyenne-II \\
\hline \multicolumn{7}{|c|}{ Purgeable priority pollutants } \\
\hline Chloroform & -- & 4.1 & 0.6 & ND & ND & ND \\
\hline Toluene & -- & 9.3 & ND & 350 & 0.3 & 230 \\
\hline Benzene & -- & ND & ND & .2 & ND & ND \\
\hline Chlorobenzene & -- & ND & ND & .3 & ND & ND \\
\hline Diethylphthalate & -- & ND & -- & ND & 5.0 & ND \\
\hline Ethylbenzene & -- & ND & ND & 2.2 & ND & 3 \\
\hline Methylene chloride & -- & ND & ND & ND & ND & 11 \\
\hline Tetrachloroethylene & -- & ND & ND & 260 & ND & 170 \\
\hline \multicolumn{7}{|c|}{ Extractable priority pollutants } \\
\hline 1,2-Dichlorobenzene & -- & ND & ND & 120 & ND & 66 \\
\hline 1,4-Dichlorobenzene & -- & ND & 56 & 21 & ND & ND \\
\hline Di-n-octylphthalate & -- & 13 & -- & ND & ND & 12 \\
\hline 2,4-Dimethylphenol & ND & ND & ND & 23 & ND & 29 \\
\hline Phenol (C6H-50H) & ND & 24 & 47 & 17 & 37 & 12 \\
\hline Bis-2-ethylhexylphthalate & -- & 49 & -- & ND & 32 & ND \\
\hline Vinyl chloride & -- & ND & ND & 7.5 & ND & ND \\
\hline Trichloroethylene & - & ND & ND & ND & ND & 5.2 \\
\hline Xylene & - & ND & ND & .7 & ND & ND \\
\hline
\end{tabular}

${ }^{1}$ Analyzed for acid-extractable priority pollutants only.

${ }^{2}$ Analyzed for purgeable and acid-extractable priority pollutants only.

erized library containing more than 70,000 reference spectrums. Several nonspecific acids and alcohols that probably are microbial degradation products of precursors commonly present in domestic wastewater were found. Concentrations of some specific compounds are given in table 21 . Note the similarity of septic-tank and seepage-pit results at Cheyenne-II.

\section{POTENTIAL FOR GROUND-WATER CONTAMINATION}

As stated previously, there were more than 46,000 septic-tank systems in use in the study area in 1990. Wastewater discharge from these systems was estimated to be 9,000 acre-ft/yr, equal to about 18 percent of the natural recharge to the upper Mojave River Basin (see "Recharge and Discharge" section of this report). Because of the high concentrations of nitrogen and bacteria in septic-tank wastewater, recharge of the wastewater was expected to degrade the quality of the underlying ground water. This study showed that nitrogen and bacteria are attenuated in the unsaturated zone. In addition, the low nitrate concentrations found in samples from shallow and deep ground water (tables 1 and 14) indicate the absence of widespread degradation of ground-water quality. In general, nitrate- $\mathrm{N}$ concentrations in ground water were less than $2 \mathrm{mg} / \mathrm{L}$.

Shallow ground water was sampled just below the water table at three of the established sites (Cheyenne-I, Choctaw, and Cajon). With the exception of one sample, nitrate- $\mathrm{N}$ concentrations were $3.1 \mathrm{mg} / \mathrm{L}$ or less, and most of the samples had concentrations less than $1 \mathrm{mg} / \mathrm{L}$ (table 14). The only sample that had a high $(13 \mathrm{mg} / \mathrm{L})$ nitrate-N concentration was collected from the suction lysimeter at $257 \mathrm{ft}$ at the Cajon site on April 12, 1989 (table 14). All prior and subsequent samples from this suction lysimeter had low nitrate- $\mathrm{N}$ concentrations (3.1 $\mathrm{mg} / \mathrm{L}$ or less). Other chemical constituents in the April 12, 1989, sample also were anomalous. This strongly suggests that this sample was mislabeled when collected and thus was from a different suction lysimeter than the one identified. 
Table 21. Extractable organic compounds, other than priority pollutants, tentatively identified in wastewater samples

[Estimated concentrations in microgram per liter. CAS No., a universal identification number for chemical compounds contained in the Chemical Abstracts Service register]

CAS No. Compound Concentration

\begin{tabular}{llr}
\hline \multicolumn{3}{c}{ Septic tank at Choctaw } \\
\hline $107-92-6$ & Butanoic acid & 220 \\
$109-52-4$ & Pentanoic acid & 410 \\
$142-61-1$ & Hexanoic acid & 410 \\
$106-44-5$ & 4-Methylphenol & 700 \\
$498-81-7$ & $\alpha, \alpha, 4-$ Trimethyleyclo- & \\
& $\quad$ hexanemethanol & 50 \\
$74663-85-7$ & Nonylcyclopropane & 130 \\
$143-07-7$ & Dodecanoic acid & 780 \\
$112-72-8$ & 1-Tetradecanol & 490 \\
$1002-84-2$ & Pentadecanoic acid & 160 \\
$57-11-4$ & Octadeconoic acid & 1,200 \\
& & \\
\hline
\end{tabular}

Septic tank at Cheyenne-II

$\begin{array}{llr}108-88-3 & \text { Methylbenzene } & 40 \\ 106-44-5 & \text { 4-Methylphenol } & 270 \\ 143-07-7 & \text { Dodecanoic acid } & 50 \\ 58-08-2 & \text { Caffeine } & 100 \\ 57-10-3 & \text { Hexadecanoic acid } & 420 \\ 36653-82-4 & \text { 1-Hexadecanol } & 50 \\ 57-11-4 & \text { Octadecanoic acid } & 440\end{array}$

Seepage pit at Cheyenne-II

\begin{tabular}{llr}
\hline $108-88-3$ & Methylbenzene & 40 \\
$143-07-7$ & Dodecanoic acid & 50 \\
$4536-30-5$ & 2-(Dodecyloxy)ethanol & 110 \\
$58-08-2$ & Caffeine & 120 \\
$2091-29-4$ & 9-Hexadecenoic acid & 110 \\
$57-10-3$ & Hexadecanoic acid & 460 \\
$57-11-4$ & Octadecanoic acid & 360 \\
\hline
\end{tabular}

To further investigate the effect of septic-tank wastewater on ground-water quality, two multiplewell monitoring sites were installed in the Apple Valley area (figs. 5 and 9). The first site (Apple Ranchos) was constructed in the center of Apple Valley in an area that is sewered (figs. 3 and 9). The second site (Rincon) was constructed about 2 mi west of the Apple Ranchos site, downgradient of numerous residences that use seepage pits to discharge septic-tank wastewater (figs. 3 and 9). The general direction of ground-water flow is from the Apple
Ranchos site toward the Rincon site. Each site includes three or four monitoring wells that enable sampling at depths between about 5 and $100 \mathrm{ft}$ below the water table (table 3). The objective in sampling at several depths was to determine the importance of dilution by vertical mixing in the saturated zone. The two sites are in a part of Apple Valley where most of the houses were constructed in the early 1960's and where depth to the water table was about 150 to 180 $\mathrm{ft}$ at the time of the study (1988-90). On the basis of estimated rates for the movement of the wastewater wetting front determined for this study $(0.07-1.0 \mathrm{ft} / \mathrm{d}$, table 15), wastewater discharged to seepage pits in this area should have reached the water table many years ago. Both sites also are east of and sufficiently far from the Mojave River to receive little if any recharge from the river. The absence of river recharge is confirmed by differences in water chemistry between these wells and other wells near the river (fig. 8; table 1). Therefore, septic-tank wastewater is believed to constitute a significant source of recharge in this part of the study area.

Water-quality data collected from the multiplewell monitoring sites are presented in table 14. If undenitrified septic-tank wastewater were recharging the shallow ground-water system, one would expect higher nitrate concentrations in samples from wells closest to the water table and at the downgradient site (Rincon). Inspection of table 14 indicates that at both Apple Ranchos and Rincon, the nitrate-N concentrations of samples from the shallowest wells were less than or equal to the concentrations in samples from the deeper wells. Samples from the shallowest well at each site had nitrate- $\mathrm{N}$ concentrations less than $0.2 \mathrm{mg} / \mathrm{L}$, and the highest nitrate- $\mathrm{N}$ concentrations, 2.0 to $4.1 \mathrm{mg} / \mathrm{L}$, were in samples from the second-deepest well $(199 \mathrm{ft})$ at the Apple Ranchos site. All nitrate- $\mathrm{N}$ concentrations in samples from the Rincon site were less than or equal to $1.0 \mathrm{mg} / \mathrm{L}$, indicating no increase in nitrate concentration in a downgradient direction. The data collected from these sites indicate that either (1) a substantial fraction of the nitrogen in septic-tank wastewater is being removed in the unsaturated zone or in the saturated zone near the water table, (2) substantial dilution is occurring over a thick saturated zone, (3) the quantity of wastewater is small in comparison with the quantity of underlying ground water, or (4) the wastewater has not yet reached the water table near the monitoring sites.

A single-cell model that considers the main sources of water and nitrate to a part of the groundwater system was used to further evaluate the importance of dilution by vertical mixing with low- 
nitrate ground water. This approach is similar to that used by Bauman and Schafer (1985), in which massbalance equations are developed for the water and nitrate in the system. Assumptions include an isotropic and homogeneous water-table aquifer, steadystate ground-water flow, and instantaneous mixing of nitrate. The purpose of the model is to illustrate the relative importance of differences in aquifer properties and nitrogen loading to changes in nitrate concentration in the ground-water system with time.

The region modeled is a 2 -mile-long by 1 -milewide block of the aquifer extending from the Apple Ranchos multiple-well monitoring site along a ground-water flow line toward the Mojave River. The total volume of ground water in the model block at any time, $Q_{\text {tor }}$, is calculated by multiplying the surface area of the block by the aquifer thickness and the porosity of the aquifer. For the purpose of this model, the aquifer thickness is assumed to equal the depth of vertical mixing of the septic-tank wastewater in the aquifer. Because of stratification in the aquifer system, the depth of vertical mixing will be much less than the aquifer thickness in most places. A verticalmixing depth of $50 \mathrm{ft}$ was chosen for most model simulations. Porosity was assumed to be 30 percent, a value which probably is high for the entire aquifer as a whole and which therefore has the effect of understating the influence of wastewater on the ground water (overestimating dilution with ground water). A value of $2 \mathrm{mg} / \mathrm{L}$ was chosen to represent the initial nitrate- $\mathrm{N}$ concentration prior to any mixing with septic-tank wastewater.

Ground-water inflow enters the model block through the upgradient boundary, and inflow through the lateral boundaries of the model block was assumed to be zero because the model block lies along parallel ground-water flow lines. Septic-tank wastewater is the only other source of recharge, and ground-water inflow and septic-tank wastewater are assumed to mix instantaneously with the ground water in the aquifer. Ground-water outflow through the downgradient end of the model block is the only output from the system. Ground water removed from the system by pumping is assumed to be balanced by septic-tank wastewater recharge (consumptive use is considered negligible). Therefore, the nitrate concentration of the ground-water outflow consists of a mixture of the ground-water inflow, the septic-tank wastewater, and the underlying ground water.

The quantity of ground-water inflow at the upgradient boundary $\left(Q_{\text {in }}\right)$ can be estimated using the following form of Darcy's law:

$$
Q_{\text {in }}=K \cdot b \cdot \frac{d h}{d l} \cdot w \cdot t
$$

$$
\begin{aligned}
\text { where } & \\
Q_{\text {in }} & =\text { quantity of ground-water inflow }\left[\mathrm{L}^{3}\right] \\
K & =\text { hydraulic conductivity }[\mathrm{L} / \mathrm{T}] \\
b & =\text { aquifer thickness of vertical mixing depth } \\
& {[\mathrm{L}] } \\
d h / d l & =\text { hydraulic gradient }[\mathrm{L} / \mathrm{L}] \\
w & =\text { width of the model block }[\mathrm{L}] \\
t & =\text { time period }[\mathrm{T}]
\end{aligned}
$$

$K$ was estimated by dividing the reported transmissivity of the aquifer $\left(20,000 \mathrm{ft}^{2} / \mathrm{d}\right.$ ) (Hardt, 1971 , fig. 8) by the saturated thickness of the Quaternary and Tertiary deposits (1,000 ft) (fig. 6). The estimated value of $K, 20 \mathrm{ft} / \mathrm{d}$, probably is less than the actual values in the upper part of the saturated deposits and greater than actual values in the lower part of the aquifer. Therefore, model simulations were done using different chosen values of $K(2,20$, and $200 \mathrm{ft} / \mathrm{d})$ to evaluate the influence of this parameter on predicted nitrate concentrations. As stated previously, the vertical mixing depth $(b)$ was assumed to be $50 \mathrm{ft}$ for most of the model simulations. Model simulations also were made with smaller and greater mixing depths $(10,100$, and 1,000 $\mathrm{ft}$ ) to evaluate the influence of mixing depth on predicted nitrate concentrations. The hydraulic gradient was determined to be $0.0012 \mathrm{ft} / \mathrm{ft}$ on the basis of water-level measurements in the vicinity of the Apple Ranchos multiple-well monitoring site. The width of the aquifer block was previously defined as $5,280 \mathrm{ft}$. The time period (step) was set equal to 1 year $(365.25 \mathrm{~d})$. Nitrate-N concentrations for the groundwater inflow $\left(N_{i n}\right)$ were assumed, on the basis of available information, to be $2 \mathrm{mg} / \mathrm{L}$.

The quantity of septic-tank wastewater $\left(Q_{s t}\right)$ mixing into the underlying ground water during any given time period was estimated-by assuming an average septic-tank discharge of $70(\mathrm{gal} / \mathrm{d}) /$ person (Bookman-Edmonston Engineering, 1991) and 2.5 persons per household-to be $175 \mathrm{gal} / \mathrm{d}$ or $23 \mathrm{ft}^{3} / \mathrm{d}$ per household. In most of the Victor Valley area, residential density ranges from 1 to 4 houses per acre. To evaluate the influence of housing density, densities of 1,2 , and 4 houses per acre were simulated in the model.

The nitrate- $\mathrm{N}$ concentration of the septic-tank wastewater $\left(N_{s t}\right)$ was chosen to be $50 \mathrm{mg} / \mathrm{L}$, slightly higher than the $46 \mathrm{mg} / \mathrm{L}$ average dissolved-nitrogen concentration for wastewater from the five sites sampled for this study (table 17). It is assumed that 
there are no losses of nitrogen after wastewater leaves the septic tank, and that all the nitrogen is entirely converted to nitrate. To evaluate the influence of lower nitrate concentrations in the wastewater and (or) denitrification of the wastewater, different concentrations of wastewater nitrate- $\mathrm{N}(50,25$, and $10 \mathrm{mg} / \mathrm{L})$ were simulated in the model.

The quantity of underlying ground water $\left(Q_{g w}\right)$ in the model block during any time period can be determined by subtracting $Q_{i n}$ and $Q_{s t}$ from $Q_{t o t}$. As stated previously, the background nitrate-N concentration of the underlying ground water prior to mixing with septic-tank wastewater $\left(N_{g w}\right)$ was assumed to be $2 \mathrm{mg} / \mathrm{L}$. The nitrate- $\mathrm{N}$ concentration of the ground water after mixing with the septic-tank wastewater is determined in the model on a yearly basis for 100 years using the following equation:

$$
\begin{gathered}
N_{\mathrm{gw}}^{\mathrm{n}+1}=\frac{1}{Q_{\mathrm{tot}}}\left(Q_{\mathrm{in}} * N_{\mathrm{in}}+Q_{\mathrm{st}} * N_{\mathrm{st}}+Q_{\mathrm{gw}} * N_{\mathrm{gw}}^{n}\right) \\
n=0,1,2, \ldots, 99,
\end{gathered}
$$

where

$n$ is the time step, in years, and all values of $N$ and $Q$ are in consistent units.

$N_{\mathrm{gw}}$ on the right side of the equation is updated with the computed $N_{\mathrm{gw}}$ for the previous time step (the left side of the equation) for each successive yearly time step. Model results for each of the different simulations are presented in figure 14 . The parameters used in the model, unless otherwise noted, are the same as those shown in table 22. The computed nitrate- $\mathrm{N}$ concentrations should be considered only as crude estimates, given the simplifying assumptions of the model.

The influence of changing porosity on the modelcomputed nitrate concentration is shown in figure $14 \mathrm{~A}$. Higher values of porosity result in lower computed nitrate concentrations during the early years before the concentrations reach a steady state. Modelcomputed concentrations are lower when the aquifer porosity is greater because initially a larger quantity of low-nitrate ground water is present in the underlying aquifer to dilute the septic-tank wastewater. Nevertheless, even the highest value of porosity simulated ( 30 percent) resulted in computed nitrate- $\mathrm{N}$ concentrations in excess of $10 \mathrm{mg} / \mathrm{L}$ in less than 20 years.

The influence of hydraulic conductivity and hydraulic gradient on model-computed nitrate concentrations is shown in figure $14 B$. Higher values of $K$ result in increased ground-water inflow (see eq. 10) and therefore in lower computed concentrations. In-
Table 22. Parameters and values used in the model

[ft $\mathrm{ft}^{3} / \mathrm{d}$, cubic foot per day; $\mathrm{ft} / \mathrm{d}$, foot per day; $\mathrm{ft}$, foot;

\begin{tabular}{|c|c|c|}
\hline & Model parameter & Parameter value \\
\hline$Q_{\text {in }}$ & $\begin{array}{l}\text { Quantity of ground-water inflow } \\
\text { Hydraulic conductivity }(K) \\
\text { Hydraulic gradient }(d h / d l) \\
\text { Vertical mixing depth }(b) \\
\text { Aquifer width }(w)\end{array}$ & $\begin{array}{c}2,314,224 \mathrm{ft}^{3} \\
20 \mathrm{ft} / \mathrm{d} \\
0.0012 \mathrm{ft} / \mathrm{ft} \\
50 \mathrm{ft} \\
5,280 \mathrm{ft}\end{array}$ \\
\hline$N_{i n}$ & $\begin{array}{l}\text { Nitrate- } N \text { concentration of } \\
\text { ground-water inflow }\end{array}$ & $2 \mathrm{mg} / \mathrm{L}$ \\
\hline \multirow[t]{4}{*}{$Q_{s t}$} & $\begin{array}{l}\text { Quantity of septic-tank } \\
\text { wastewater }\end{array}$ & $10,939,968 \mathrm{ft}^{3}$ \\
\hline & $\begin{array}{l}\text { Average septic-tank } \\
\text { discharge }\end{array}$ & $23.4\left(\mathrm{ft}^{3} / \mathrm{d}\right) /$ house \\
\hline & Housing density & 1 house/acre \\
\hline & $\begin{array}{l}\text { Number of acres in model } \\
\text { area }\end{array}$ & 1,280 acres \\
\hline$N_{s t}$ & $\begin{array}{l}\text { Nitrate- } N \text { concentration of } \\
\text { septic-tank wastewater }\end{array}$ & $50 \mathrm{mg} / \mathrm{L}$ \\
\hline \multirow[t]{5}{*}{$Q_{g w}$} & $\begin{array}{l}\text { Quantity of underlying } \\
\text { ground water }\end{array}$ & $836,352,000 \mathrm{ft}^{3}$ \\
\hline & Aquifer length $(l)$ & $10,560 \mathrm{ft}$ \\
\hline & Aquifer width $(d)$ & $5,280 \mathrm{ft}$ \\
\hline & Vertical-mixing depth $(b)$ & $50 \mathrm{ft}$ \\
\hline & Aquifer porosity & 30 percent \\
\hline$N_{g w}^{\mathrm{n}=0}$ & $\begin{array}{l}\text { Nitrate-N concentration of } \\
\text { underlying ground water }\end{array}$ & $2 \mathrm{mg} / \mathrm{L}$ \\
\hline
\end{tabular}
$\mathrm{mg} / \mathrm{L}$, milligram per liter]

creasing the hydraulic gradient would have the same effect as increasing $K$ (see eq. 10); that is, greater dilution with low-nitrate ground water. Again, the predicted nitrate- $\mathrm{N}$ concentration was in excess of 10 $\mathrm{mg} / \mathrm{L}$ in less than 20 years, even when the effect of dilution was maximized by selecting a high value for $K(200 \mathrm{ft} / \mathrm{d})$.

The influence of different housing densities on model-computed nitrate concentrations is shown in figure $14 C$. Increasing the housing density results in a proportional increase in the quantity of septic-tank wastewater that recharges the underlying ground water. Even at 1 house per acre (the lowest housing density simulated), computed nitrate- $\mathrm{N}$ concentrations would exceed $10 \mathrm{mg} / \mathrm{L}$ in less than 20 years.

The influence of vertical-mixing depth is shown in figure $14 D$. Increases in the vertical-mixing depth result in lower model-computed nitrate concentrations 


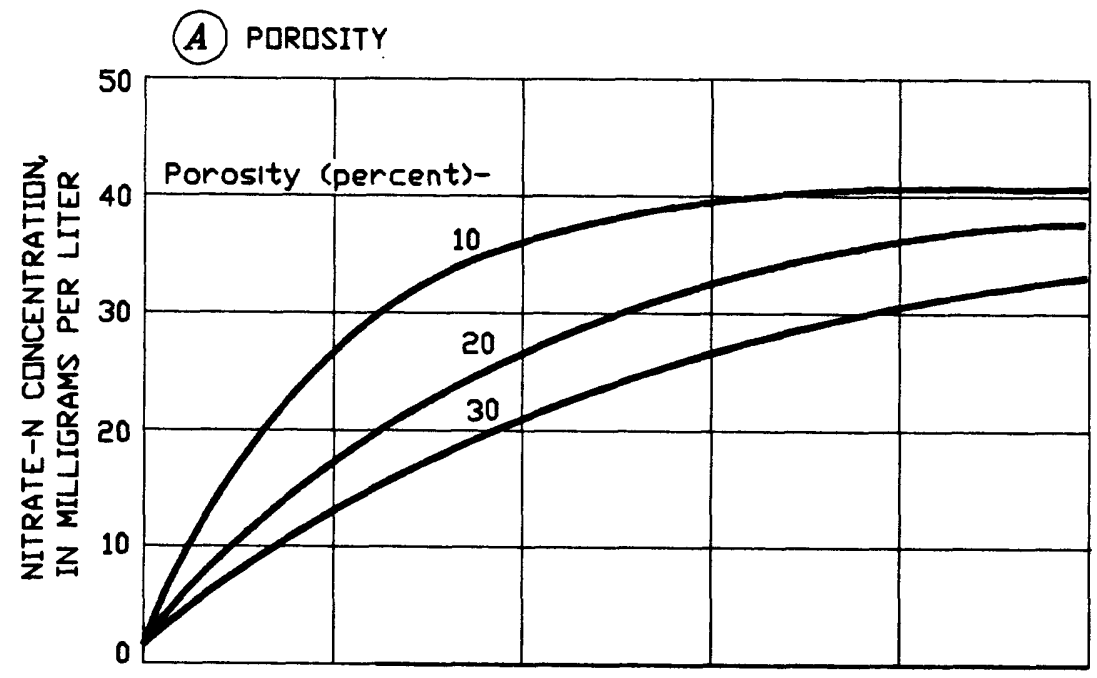

(B) HYDRAULIC CONDUCTIVITY $K$ AND GRADIENT $I$

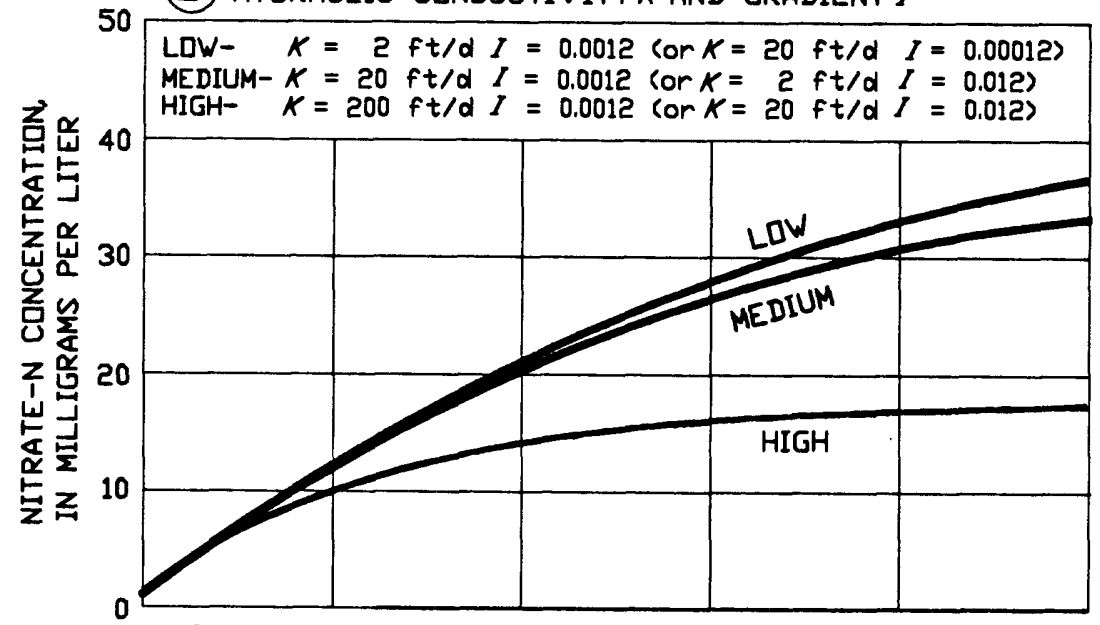

(C) HDUSING DENSITY

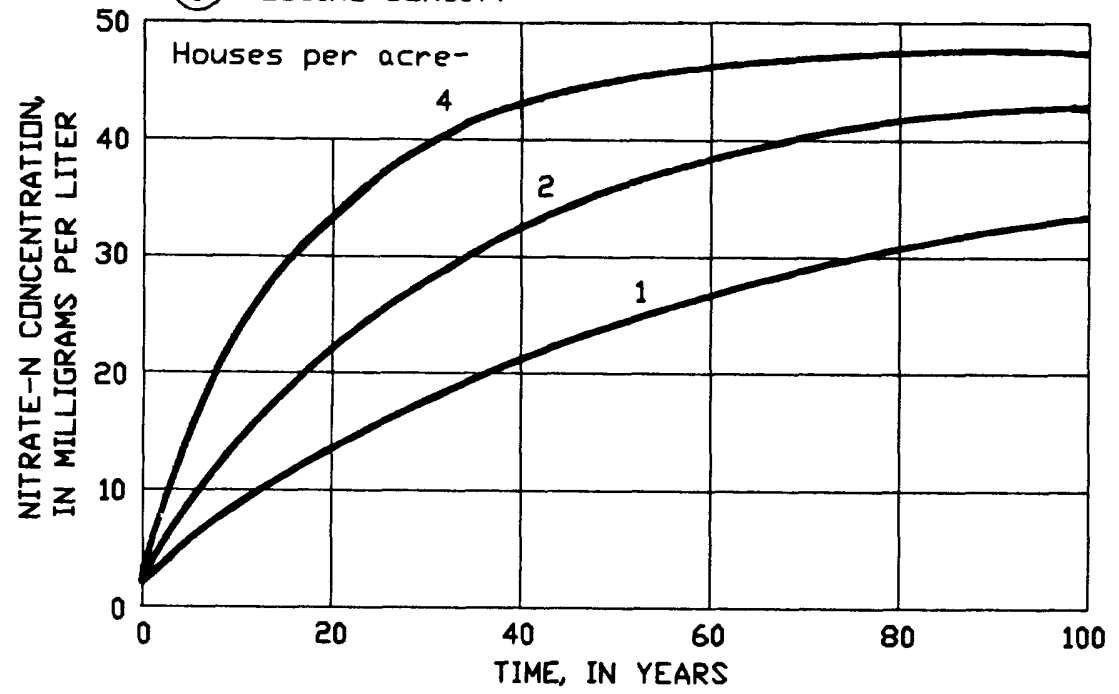

Figure 14. Influence of selected parameters on modelcomputed nitrate concentrations in ground water. because (1) the quantity of groundwater inflow increases directly with increases in the vertical-mixing depth (eq. 1), and (2) the quantity of ground water initially available to mix with septic-tank wastewater increases directly with the verticalmixing depth. When a verticalmixing depth equal to the total saturated thickness of the aquifer $(1,000 \mathrm{ft})$ was chosen, computed nitrate- $\mathrm{N}$ concentrations did not exceed $10 \mathrm{mg} / \mathrm{L}$ during the entire 100 -year simulation period. However, for more realistic vertical-mixing depths of $100 \mathrm{ft}$ and less, the computed nitrate- $\mathrm{N}$ concentrations exceeded $10 \mathrm{mg} / \mathrm{L}$ in less than 30 years, and measurable increases are simulated within 5 to 10 years.

The effect of reducing the septictank wastewater nitrate concentration is shown in figure $14 E$. The previous simulations all used a nitrate- $\mathrm{N}$ concentration of $50 \mathrm{mg} / \mathrm{L}$ for the septic-tank wastewater. In all these simulations, except when the mixingzone depth was in excess of $100 \mathrm{ft}$, the predicted nitrate- $\mathrm{N}$ concentrations exceeded $10 \mathrm{mg} / \mathrm{L}$ in less than 30 years. When the nitrate-N concentration of the wastewater is reduced to $25 \mathrm{mg} / \mathrm{L}$ (a 50-percent reduction), model-simulated nitrate- $\mathrm{N}$ concentrations do not exceed 10 $\mathrm{mg} / \mathrm{L}$ for more than 30 years, assuming the best-estimate parameter values given in table 22 . Reducing the nitrate- $\mathrm{N}$ concentration of the wastewater to $10 \mathrm{mg} / \mathrm{L}$ (an 80percent reduction) obviously results in predicted nitrate- $\mathrm{N}$ concentrations that do not exceed $10 \mathrm{mg} / \mathrm{L}$ during the entire simulation period.

The results of these model simulations indicate that if the vertical-mixing depth is $100 \mathrm{ft}$ or less and if the values used for the other model parameters are reasonable (table 22), then the nitrate concentration of ground water in the Victor Valley area should be increasing at a 
(D) MIXING DEPTH

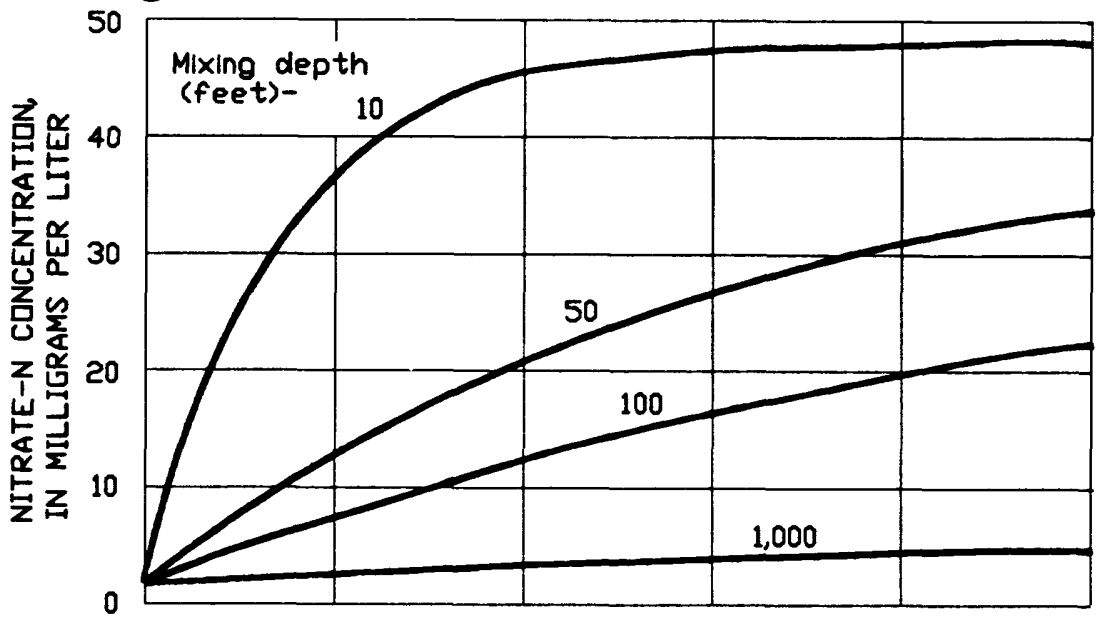

(E) NITRATE-N CINCENTRATION DF SEPTIC-TANK WASTEWATER

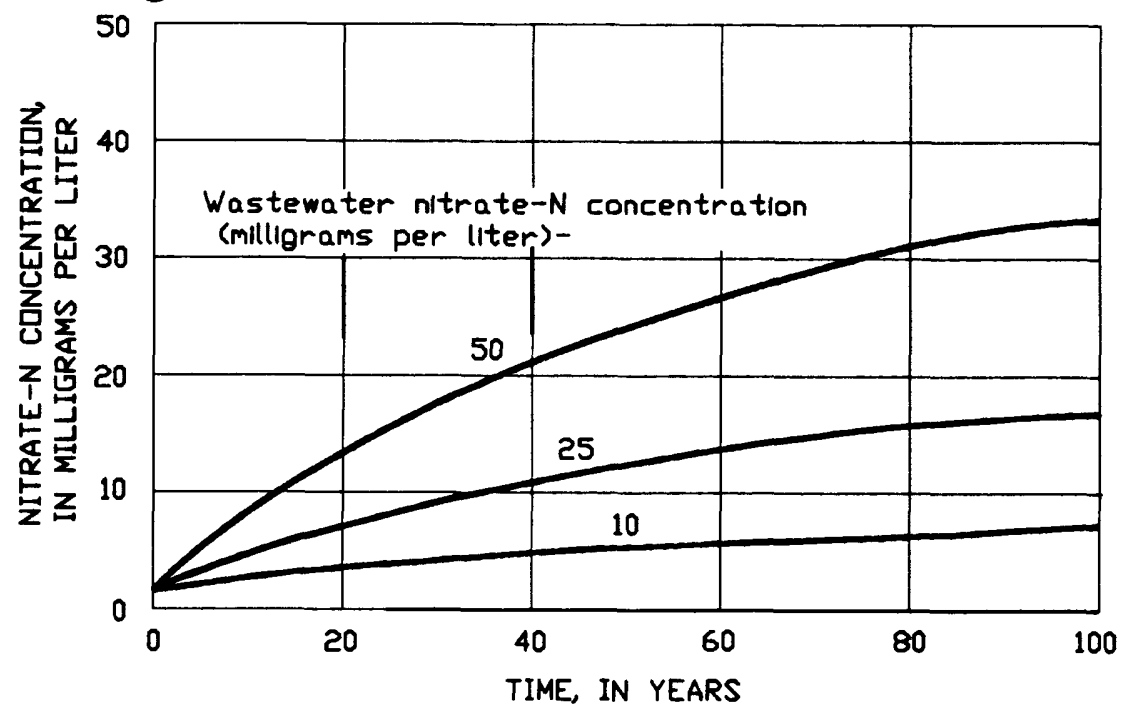

Figure 14--Continued.

readily discernible rate. The low nitrate concentrations measured in samples of ground water from the Victor Valley suggest that either nitrogen is being removed from the septic-tank wastewater, the vertical-mixing depth must be substantially greater than $100 \mathrm{ft}$, or a large percentage of the septic-tank wastewater has not yet reached the water table. Differences in several water-quality characteristics with depth at the Apple Ranchos and Rincon multiple-well monitoring sites (table 14) indicate that the vertical-mixing depth is less than $100 \mathrm{ft}$ and thus support the contention that some nitrogen is being removed in the unsaturated zone or in the saturated zone near the water table in the study area.

In addition to providing indirect support for the existence of a nitrogen-removal process, the model simulations also imply that any temporal trends in ground-water degradation would be sufficiently slow that continued monitoring, especially in multiple-depth piezo- meters distributed locally beneath seepage pits as well as regionally near the water table, can provide adequate early indication of possible degradation. Continued monitoring also is important to any further decisions on the need for sewering given the highly variable distribution of environments that favor denitrification and the absence of knowledge on their capacity to sustain denitrification and the uncertainty, therefore, inherent in quantifying wastewater-nitrate loading to the ground water on either a local or a regional scale.

The nitrate concentrations present in ground water underlying the study area are much lower than the concentrations that have been measured in other areas with high septic-tank densities: for example, Long Island, New York ( $\mathrm{Ku}$ and Sulam, 1976); Delaware (Miller, 1975); southern Florida (Pitt and others, 1975); Fresno, California (Schmidt, 1972); and Tucson, Arizona (Martin, 1980). A possible explanation for the low nitrate concentrations in this study area is that the unsaturated zone is much thicker than in most of those areas and wastewater movement is sufficiently slow to allow greater opportunity for attenuation of nitrogen in the unsaturated zone. If the unsaturated zone were thinner and (or) more permeable, wastewater-transit times through the unsaturated zone might be so rapid that attenuation would not occur. Another explanation for the observed low nitrate concentrations is that there are few domestic wells in the area at which possible faulty well construction could allow the septic-tank wastewater to "short circuit" the thick unsaturated zone and enter the aquifer. An unusual aspect of the upper Mojave River Basin, as a septic-tank area, is that virtually all the area is serviced by several principal water purveyors. These water purveyors distribute ground water pumped from large municipal 
supply wells by pipelines to individual residences. In most other septic-tank areas, there commonly is one well for each septic tank. The wells usually are small domestic wells that do not have to meet the same stringent construction standards that are applied to large municipal supply wells. Therefore, there are many more chances (in most other septic-tank areas) for faulty well construction (inadequate sanitary seals) or failed wells (corroded casings or leaking seals) to short circuit septic-tank wastewater directly to the water table.

In summary, the data collected for this study indicate that when the study was completed (except for limited continued monitoring) in 1990, septic-tank wastewater had not degraded ground-water quality in the upper Mojave River Basin. Septic-tank wastewater is a significant source of recharge to the ground-water system in the basin. If the entire area were sewered, this wastewater would be treated at a regional wastewater treatment plant and then likely would be discharged to the Mojave River east of the "Narrows" downgradient of the upper Mojave River Basin. This source of recharge then would be exported from the study area, creating a larger imbalance between recharge and discharge; this imbalance would result in water-level declines that are greater than would otherwise occur. Of course, if wastewater were no longer discharged from seepage pits, any contaminants in wastewater still present in the unsaturated zone would simply remain there and would no longer be transported to the water table.

\section{SUMMARY AND CONCLUSIONS}

Septic-tank wastewater disposed in seepage pits at 46,000 residences in the rapidly developing upper Mojave River Basin (Victor Valley) northeast of Los Angeles is estimated to equal about 18 percent of the natural recharge to the underlying aquifer. However, this wastewater-disposal practice has led to concern about possible contamination, especially by nitrate, of the sole-source aquifer that underlies the area. To respond to this concern, the U.S. Geological Survey began a study in 1988 to (1) determine vertical rate of wastewater movement through the unsaturated zone, (2) determine whether constituents in wastewater reach the water table, and (3) evaluate the current and potential effects of wastewater discharge on ground-water quality. The study entailed monitoring wastewater movement and water-quality changes in the unsaturated zone at eight residences and determining regional ground-water quality in multipledepth piezometers near the water table at two locations.
Disposal of domestic wastewater is achieved by discharge of septic-tank effluent to seepage pits (30-foot-deep dry wells) from which the wastewater percolates into the unsaturated zone below a near-surface caliche layer that extends throughout most of the Victor Valley. Movement of the wastewater was observed by means of periodic neutron logging and periodic sampling of suction lysimeters beneath the seepage pits. Water-quality changes in the unsaturated zone were determined by analysis of suction-lysimeter samples and by extraction of soil cores. Bacteria in the unsaturated zone were analyzed from soil cores. The eight residential sites that were studied were selected to represent the range in geohydrologic environments that prevail in the Victor Valley. The sites included three newly occupied residences as well as other residences whose disposal systems had been in use for as long as 10 years. Six were single-family residences and two were multiple-family residences. The interpretation of results from this study area was less complicated than for many other published investigations of septic-tank effects because of (1) the absence of other nitrogen sources in this desert environment (agricultural areas adjacent to the Mojave River channel were avoided) where landscaping is minimal, and (2) the presence of only a few large municipal-supply wells rather than numerous individual-homeowner wells.

The measured vertical rate of the wastewater wetting front ranged from 0.07 to 1.0 foot per day, indicating that the wastewater wetting front reaches the water table, at an average depth of 150 feet in the study area, in about 6 years and about 6 months, respectively. The time for the wastewater to reach the water table would be longer. Although there is evidence of lateral wastewater movement, these vertical rates imply that wastewater from many of the disposal systems in Victor Valley already has reached the water table. Therefore, the absence of widespread high nitrate concentrations in ground water near the water table indicates that either a significant fraction of the nitrogen present in wastewater is no longer present when it mixes into the ground water, or the nitrate is confined to shallow depths below the water table that have not been sampled. Denitrification in the unsaturated zone and (or) at the water table beneath disposal systems seems to be a possible mechanism of nitrogen removal. Another mechanism is dilution by vertical mixing with low-nitrate ground water in a thick unsaturated zone.

Concentrations of total dissolved nitrogen in wastewater ranged from 22 to 63 milligrams per liter and averaged 46 milligrams per liter. The nitrogen 
was present in reduced form as ammonium and as organic nitrogen. Dissolved organic carbon concentrations in wastewater ranged from 10 to 63 milligrams per liter. All concentrations are within the expected range for domestic wastewater, and the differences between residences probably are related to the way its occupants use the water and to the quantities they use.

The reduced nitrogen present in wastewater is oxidized, presumably by nitrifying bacteria, in the soil zone close to the seepage pit. Accordingly, maximum median nitrate- $\mathrm{N}$ concentration in lysimeter samples ranged from 6.4 to 43 milligrams per liter, and the highest concentrations usually occurred in a shallow lysimeter only a short distance below the seepage pit. For the five established sites, the dissolved-nitrogen concentration averaged 27 milligrams per liter, about 40 percent less than the averaged nitrogen concentration in septic-tank wastewater at the same site. The results of this study indicate a significant removal of nitrogen in the seepage pit and (or) in the soil immediately adjacent to the seepage pit. Further declines in nitrate concentration and nitrate-to-chloride ratios were observed with increasing depth, and these decreases seemed to coincide with the presence of finer soils and with the presence of nitrate-respiring bacteria identified in soils from the two sites where these bacterial analyses were done. However, more recent results suggest the possibility that low nitrate concentrations in deeper parts of the unsaturated zone could be due to the fact that wastewater had not yet arrived at these depths during the initial period of monitoring before 1990 at the Cheyenne-I and Cajon sites. Monitoring is continuing at both sites.

The precise reduction in nitrate concentration of wastewater as it recharges at the water table is difficult to ascertain because of variability in concentration among multiple sample collections; a temporal trend toward steady-state conditions only after numerous successive samplings; nonideal selection of depth for installation of the deepest lysimeter (which can be related to uncertainty and fluctuations in depth to water table); and the inherent limitations on obtaining representative water-quality samples from an unsaturated zone using suction lysimeters. At one of the residential study sites, Cajon, a decrease of approximately 50 percent in nitrate concentration was found at the deepest in a series of six lysimeters between 35 and 199 feet, the deepest of which still is well above a declining water table that was at least 266 feet below land surface in late 1991. Incomplete results from ongoing sampling of the lysimeters at this site indicate that the reduction in nitrate concentration is accompanied by an apparent isotopic fractionation (enrichment of ${ }^{15} \mathrm{~N}$ at the lower nitrate concentration at 199 feet) factor of about -10 permil and that the reaction may be mediated by autotrophs (chemlithotrophs). Enrichment in ${ }^{15} \mathrm{~N}$ in the residual nitrate, and absence of widespread high levels of nitrate in the regional ground water and in ground water near the water table provide evidence for at least partial removal of nitrogen in wastewater recharge by denitrification. However, the significance of this reaction throughout the study area, and the capacity to sustain the reaction for a long period of time, cannot be evaluated.

Although fecal-coliform densities ranged from about $5 \times 10^{4}$ to $4 \times 10^{5}$ colony-forming units per 100 milliliters in the wastewater itself, fecal coliforms never were detected in any soil samples analyzed, including those only a few feet away from the seepage pits. Comparison of published transport properties for other microorganisms with those of fecal coliform suggests that various other pathogenic bacteria and viruses that might be present in domestic wastewater also are unlikely to persist a great distance from the seepage pits.

Of 85 organic priority pollutants analyzed, 17 were detected in domestic wastewater, mostly at low concentrations. At one site (Cheyenne-II), concentrations were high-but the high concentrations are believed to be a consequence of disposal practices unique to this particular residence. Concentrations of toluene, tetrachloroethylene, and 1,2-dichlorobenzene approached or exceeded 100 micrograms per liter in both the septic tank and the seepage pit at this site. No extractable priority pollutants were detected in soils adjacent to the seepage pit at this site or at three other sites.

About one-quarter of all inhabitants of the United States dispose of sewage by means of onsite septic systems that have the potential to contaminate the receiving waters. The main cause of failure of these systems has been variously reported to be poor operation and maintenance, unsuitable soils, and excessive septic-tank density. Although these conditions exist locally at some residences and regionally in some parts of the upper Mojave River Basin, results of this study show that current onsite domestic-wastewater disposal practices pose little immediate threat to the local ground-water resource. Continued monitoring in the unsaturated zone and in wells perforated just below the water table could provide adequate warning of any future ground-water degradation, which model simulations indicate can occur only over a period of many years. Although discontinuance of current domestic-disposal practices 
in favor of a municipal treatment plant would eliminate any further transport of contaminants through the unsaturated zone, it also would result in greater water-level declines if this source of recharge were exported from the area.

\section{References Cited}

Adelman, D.D., and Spalding, R.F., 1988, The economic feasibility of using ethanol to accelerate groundwater denitrification, in Proceedings on Planning Now for Irrigation and Drainage: Irrigation Division, American Society of Civil Engineers, Lincoln, Nebraska, July 19-21, 1988, p. 206-213.

American Society for Testing and Materials, 1988, Soil and rock, building stone; geotextiles: Annual Book of ASTM Standards, section 4, v. 04.08, Library of Congress catalogue card no. 83-641658.

Bartholomew, W.V., and Clark, F.E., eds., 1965, Soil nitrogen: American Society of Agronomy, Inc., Madison, Wisconsin: Agronomy Monograph 10,615 p.

Bauman, B.J., and Schafer, W.M., 1985, Estimating ground-water quality impacts from on-site sewage treatment systems, in Proceedings of the Fourth National Symposium on Individual and Small Community Sewage Systems: American Society of Agricultural Engineers, New Orleans, Louisiana, December 10-11, 1984, p. 285-294.

Bookman-Edmonston Engineering, Inc., 1991, Investigation for the establishment of zones of benefit: draft consultant report prepared for Mojave Water Association, Glendale, California, $34 \mathrm{p}$.

Bouwer, Herman, 1978, Groundwater Hydrology: New York, McGraw-Hill, $480 \mathrm{p}$.

Böttcher, J., Strebel, O., Voerkelius, Susanne, and Schmidt, H.-L., 1990, Using isotope fractionation of nitratenitrogen and nitrate-oxygen for evaluation of microbial denitrification in a sandy aquifer: Journal of Hydrology, v. 114, p. 413-424.

Boyle, W.C., and Otis, R.J., 1979, On-site alternatives for treatment and disposal: Journal of the Water Pollution Control Federation, v. 51, p. 1223-1229.

Britton, L.J., and Greeson, P.E., eds., 1987, Methods for collection and analysis of aquatic biological and microbiological samples: U.S. Geological Survey Techniques of Water-Resources Investigations, Book 5, Chapter A4, 363 p.

Broadbent, F.E., and Clark, F.E., 1965, Denitrification, in Bartholomew, W.V., and Clark, F.E., eds., Soil nitrogen: American Society of Agronomy, Inc., Madison, Wisconsin, Agronomy Monograph 10, p. 344-359.

Brown, K.W., Wolf, H.W., Donnelly, K.C., and Slowey, J.F., 1979, The movement of fecal coliforms and coliphages below septic lines: Journal of Environmental Quality, v. 8, p. 121-125.
California Department of Water Resources, 1967, Mojave River ground water basins investigation: Bulletin No. 84,151 p., 9 pls. in pocket.

Canter, L.W., and Knox, R.C., 1985, Septic tank system effects on ground water quality: Chelsea, Michigan, Lewis Publishers, Inc., $336 \mathrm{p}$.

Clark, H.F., and Kabler, P.W., 1964, Reevaluation of the significance of the coliform bacteria: Journal of the American Water Works Association, v. 46, p. 931-936.

Dazzo, F.B.., and Rothwell, D.F., 1974, Evaluation of porcelain cup water samplers for bacterial samplings: Applied Microbiology, v. 27, p. 1172-1174.

Delwiche, C.C., and Steyn, P.L., 1970, Nitrogen isotope fractionation in soils and microbial reactions: Environmental Science and Technology, v. 4, p. 929-935.

Duda, A.M., and Cromartie, K.D., 1982, Coastal pollution from septic tank drainfields: American Society of Civil Engineers, Journal of the Environmental Engineering Division, v. 108, p. 1265-1279.

Engesgaard, Peter, and Kipp, K.L., 1992, A geochemical transport model for redox-controlled movement of mineral fronts in groundwater flow systems: a case of nitrate removal by oxidation of pyrite: Water Resources Research, v. 28, p. 2829-2843.

Feltz, H.R., Duncan, S.S., and Zepp, Ann, eds., 1985, 1986-87-88 National Water-Quality Laboratory services catalog: U.S. Geological Survey Open-File Report 86-232, 5 parts.

Fishman, M.J., and Friedman, L.C., eds., 1989, Methods for determination of inorganic substances in water and fluvial sediments: U.S. Geological Survey Techniques of Water-Resources Investigations, Book 5, Chapter A1, 545 p.

Fritz, P., and Fontes, J.Ch., 1980, Introduction, in Fritz, P., and Fontes, J.Ch., eds., Handbook of Environmental Geochemistry, v. 1, The Terrestrial Environment, A: Elsevier, New York, Chapter 1, p. 1-19.

Ghuman, B.S., and Prihar, S.S. 1980, Chloride displacement by water in homogeneous columns of three soils: Soil Science Society of America Journal, v. 44, p. $17-21$.

Hagedorn, C., Hansen, D.T., and Simonson, G.H., 1978, Survival and movement of fecal indicator bacteria in soil under conditions of saturated flow: Journal of Environmental Quality, v. 7, p. 55-59.

Hardt, W.F., 1971, Hydrologic analysis of Mojave River basin, California, using electric analog model: U.S. Geological Survey Open-File Report [71-157], 84 p.

Harvey, R.W., Smith, R.L., and George, L., 1984, Effect of organic contamination upon microbial distributions and heterotrophic uptake in a Cape Cod, Mass., aquifer: Applied and Environmental Microbiology, v. 48, p. 1197-1202.

Heaton, T.H.E., Talma, A.S., and Vogel, J.C., 1983, Origin and history of nitrate in confined ground waters in the western Kalahari: Journal of Hydrology, v. 62, p. 243-262. 
Hillel, D., 1971, Soil and water: physical principles and processes: New York, Academic Press, 288 p.

Hübner, H., 1986, Isotope effects of nitrogen in the soil and biosphere, chapter 9, in Fritz, P. and Fontes, J.Ch., eds.: Handbook of Environmental Isotope Geochemistry, v. 2, The Terrestrial Environment, B: New York, Elsevier, p. 361-425.

John S. Murk Engineering, Inc., and LeRoy Crandall and Associates, 1985, Historic and present conditions upper Mojave River basin: Consulting report for the Mojave Water Agency, $51 \mathrm{p}$.

Khanbilvardi, R.N., and Long, D.A., 1985, Effect of soil depth on wastewater renovation: Journal of Environmental Health, v. 47, p. 184-188.

Korom, S.F., 1992, Natural denitrification in the saturated zone: a review: Water Resources Research, v. 28, p. 1657-1668.

Ku, H.F.H. and Sulam, D.J., 1976, Distribution and trend of nitrate, chloride and total solids in water in the Magothy aquifer in southeast Nassau County, New York, from the 1950's through 1973: U.S. Geological Survey Water-Resources Investigations Report 76-44, $47 \mathrm{p}$.

Lance, J.C., 1986, Effect of sludge additions on nitrogen removal in soil columns flooded with secondary effluent: Journal of Environmental Quality, v. 15, 298-301.

Lance, J.C., and Gerba, C.P., 1984, Virus movement in soil during saturated and unsaturated flow: Applied and Environmental Microbiology, v. 47, p. 335-337.

Lance, J.C., and Whisler, F.D., 1976, Stimulation of denitrification in soil columns by adding organic carbon to wastewater: Journal of the Water Pollution Control Federation, v. 48, p. 346-356.

Lance, J.C. Rice, R.C., and Gilbert, R.G., 1980, Renovation of wastewater by soil columns flooded with primary effluent: Journal of the Water Pollution Control Federation, v. 52, p. 381-388.

Létolle, René, 1980, Nitrogen-15 in the natural environment, in Fritz, P., and Fontes, J.Ch., eds., Handbook of Environmental Isotope Geochemistry, v. 1, The Terrestrial Environment, A: New York, Elsevier, p. 407-433.

Mariotti, André, 1986, La dénitrification dans les eaux souterraines, principes et méthodes de son identification: une revue: Journal of Hydrology, v. 88, p. $1-23$.

Mariotti, André, Germon, J.C., and Leclere, A., 1982, Nitrogen isotope fractionation associated with the $\mathrm{NO}_{2}{ }^{\circ}$ $\rightarrow \mathrm{N}_{2} \mathrm{O}$ step of denitrification in soils: Canadian Journal of Soil Science, v. 62, p. 227-241.

Mariotti, André, Landreau, Alain, and Simon, Béatrice, $1988,{ }^{15} \mathrm{~N}$ isotope biogeochemistry and natural denitrification process in groundwater: application to the chalk aquifer of northern France: Geochimica et Cosmochimica Acta, v. 52, p. 1869-1878.

Martin, Peter, 1980, Evaluation of ground-water quality in the Cortaro area, Arizona: Tucson, University of Arizona, unpublished M.S. thesis, $99 \mathrm{p}$.
Matthess, G., Pekdeger, A., and Schroeter, J., 1988, Persistence and transport of bacteria and viruses in groundwater-a conceptual evaluation: Journal of Contaminant Hydrology, v. 2, p. 171-188.

McCarty, P.L., Beck, L.A., and St. Amant, P.O., 1969, Biological denitrification of wastewaters by addition of organic materials, in Proceedings of the 24th Annual Purdue Industrial Waste Conference, Lafayette, Indiana, p. 1271-1285.

Miller, J.C., 1975, Nitrate contamination of the water-table aquifer by septic tank systems in the Coastal Plain of Delaware, in Jewell, W.J. and Swand, R., eds., Water pollution control in low density areas: Hanover, N.H., University Press of New England, p. 121-133.

Nakajima, M., Hayamizu, T., and Nishimura, H., 1984, Effect of oxygen concentration on the rates of denitrification and denitrification in the sediments of an eutrophic lake: Water Research, v. 18, p. 335-338.

National Oceanic and Atmospheric Administration, 1989, Climatological data--California: v. 93, nos. 1-13.

National Research Council, 1978, Nitrates: An environmental assessment: Washington, D.C., National Academy of Sciences, 723 p.

Nightingale, H.I., and McCormick, R.L., 1985, Chemical quality of perched septic tank effluent for plant use and recharge: Journal of the Water Pollution Control Federation, v. 57, p. 916-920.

Parizek, R.R., and Lane, B.E., 1970, Soil-water sampling using pan and deep pressure-vacuum lysimeters: Journal of Hydrology, v. 11, p. 1-21.

Peters, C.A., and Healy, R.W., 1988, The representativeness of pore water samples collected from the unsaturated zone using pressure-vacuum lysimeters: Ground-Water Monitoring Review, v. 8., p. 96-101.

Pitt, W.A., Jr., Mattraw, H.C., Jr., and Klein, H., 1975, Ground-water quality in selected areas serviced by septic tanks, Dade County, Florida: U.S. Geological Survey Open-File Report 75-607, 82 p.

Postma, D., Boesen, C., Kristiansen, H., and Larsen, F., 1991, Nitrate reduction in an unconfined sandy aquifer: water chemistry, reduction processes, and geochemical modeling: Water Resources Research, v. 27, p. 2027-2045.

Reneau, R.B., Jr., 1978, Influence of artificial drainage on penetration of coliform bacteria from septic tank effluents into wet tiled drain soils: Journal of Environmental Quality, v. 7, p. 23-30.

Rice, R.C., and Bouwer, H., 1984, Soil-aquifer treatment using primary effluent: Journal of the Water Pollution Control Federation, v. 56, p. 84-90.

Rönner, U., and Sörensson, F., 1985, Denitrification rates in the low-oxygen waters of the stratified Baltic Proper: Applied Environmental Microbiology, v. 50, p. 801-806.

San Bernardino County Planning Department, 1979, San Bernardino County general plan, land use, Victorville: 1 map. 
Schmidt, K.D., 1972, Nitrate in ground water of the Fresno-Clovis metropolitan area, California: Ground Water, v. 10, p. 50-61.

Schroeder, R.A., and Martin, Peter, 1992, Nitrogen attenuation during transport of domestic wastewater through a thick unsaturated zone in the Mojave Desert: EOS, Transactions of the American Geophysical Union, Abstract, v. 73, no. 43, p. 209.

Schroeder, R.A., Martin, Peter, and Böhlke, J.K., 1993, Chemical, isotopic, and microbiological evidence for denitrification during transport of domestic wastewater through a thick unsaturated zone in the Mojave Desert, San Bernardino County, California: U.S. Geological Survey Open-File Report 93-414, 11 p.

Schroeder, R.A., Setmire, J.G., and Densmore, J.N., 1991, Use of stable isotopes, tritium, soluble salts, and redox-sensitive elements to distinguish ground water from irrigation water in the Salton Sea basin, in Ritter, W.F., ed., Proceedings of National Conference, Irrigation and Drainage Division, American Society of Civil Engineers, Honolulu, Hawaii, July 22-26, 1991, p. 524-530.

Siegrist, R., 1977, Waste segregation as a means of enhancing onsite wastewater management: Journal of Environmental Health, v. 40, p. 5-8.

Sinton, L.W., 1986, Microbial contamination of alluvial gravel aquifers by septic tank effluent: Water, Air, and Soil Pollution, v. 28, p. 407-425.

Slichter, C.S., 1905, Field measurements of the rate of movement of underground waters: U.S. Geological Survey Water-Supply and Irrigation Paper 140, 64 p.

Smith, R.L., and Duff, J.H., 1988, Denitrification in a sand and gravel aquifer: Applied and Environmental Microbiology, v. 54, p. 1071-1078.

Smith, R.L., Howes, B.L., and Duff, J.H., 1991, Denitrification in nitrate-contaminated groundwater: Occurrence in steep vertical geochemical gradients: Geochimica et Cosmochimica Acta, v. 55, p. 1815-1825.

Steenhuis, T.S., Selker, J.S., Bell, Jennifer, Kung, K-J.S., and Farlange, J-Y., 1991, Effects of soil layering on infiltration, in Ritter, W.F., ed., Proceedings of National Conference, Irrigation and Drainage Division, American Society of Civil Engineers, Honolulu, Hawaii, July 22-26, 1991, p. 74-80.

Stewart, L.W., Carlile, B.L., and Cassel, D.K., 1979, An evaluation of alternative simulated treatments of septic tank effluent: Journal of Environmental Quality, v. 8, p. $397-403$.

Stiff, H.A., Jr., 1951, The interpretation of chemical water analysis by means of patterns: Journal of Petroleum Technology, v. 3, no. 10, p. 15-17.
Subsurface Surveys, Inc., 1990, Inventory of groundwater stored in the Mojave River basins: final consultant report prepared for Mojave Water Agency, Solana Beach, California, $47 \mathrm{p}$.

Tiedje, J.M., Sexstone, A.J., Myrold, D.D., and Robinson, J.A., 1982, Denitrification: ecological niches, competition, and survival: Antonie van Leeuwenhoek Journal of Microbiology and Serology, v. 48, p. 569-583.

Troxler Electronic Laboratories, Inc., 1983, Instruction manual, depth moisture gages, Research Triangle Park, N.C., 55 p.

U.S. Environmental Protection Agency, 1976, Quality criteria for water: Washington, D.C., U.S. Environmental Protection Agency, 256 p.

Viraraghavan, T., 1976, Septic tank efficiency: American Society of Civil Engineering Journal of the Environmental Engineering Division, v. 102, p. 505-508.

1986, The future of onsite wastewater systems: Biocycle, v. 27, p. 44-45.

Viraraghavan, T., and Hashem, Simon, 1986, Trace organics in septic tank effluent: Water, Air, and Soil Pollution, v. 28, p. 299-308.

Vogel, J.C., Talma, A.S., and Heaton, T.H.E., 1981, Gaseous nitrogen as evidence for denitrification in groundwater: Journal of Hydrology, v. 50, p. 191-200.

Walker, W.G., Bouma, J., Keeney, D.R., and Magdoff, F.R., 1973a, Nitrogen transformation during subsurface disposal of septic tank effluent in sands: I. Soil transformations: Journal of Environmental Quality, v. 2 , p. $475-480$.

Walker, W.G., Bouma, J., Keeney, D.R., and Olcott, P.G., 1973b, Nitrogen transformation during subsurface disposal of septic tank effluent in sands: II. Ground water quality: Journal of Environmental Quality, v. 2, p. 521-525.

Warrick, A.W., Biggar, J.W., and Nielsen, D.R., 1971, Simultaneous solute and water transfer in an unsaturated soil: Water Resources Research, v. 7, p. 1216-1225.

Wershaw, R.L., Fishman, M.J., Grabbe, R.R., and Lowe, L.E., eds, 1987, Methods for the determination of organic substances in water and fluvial sediments: U.S. Geological Survey Techniques of Water-Resources Investigations, Book 5, Chapter A3, $80 \mathrm{p}$.

Yates, M.F., 1985, Septic tank density and ground-water contamination: Ground Water, v. 23, p. 586-591.

Young, M.H., Wieranga, P.J., Hills, R.G., and Vinson, J., 1992, Evidence of piston flow in two large-scale field experiments, Las Cruces trench site: Eos, Transactions of the American Geophysical Union, v. 73, no. 43, p. 156. 